\title{
Держава та
}

períoни

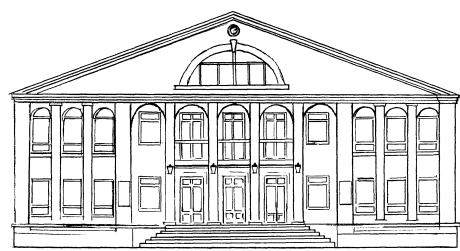

\section{Серія: ПРАВО 2020 р., № 3 (69)}

\section{Науково-виробничий журнал}

Голова редакційної ради: О. В. Покатасва, доктор юридичних наук, доктор економічних наук, професор

Головний редактор:

П. С. Покатаєв, доктор юридичних наук, доктор наук з державного управління, профессор, перший проректор, Класичний приватний університет

Редакційна колегія:

О. Ю. Синявська, доктор юридичних наук, професор, Харківський національний університет внутрішніх справ

А. М. Апаров, доктор юридичних наук, професор, професор кафедри права та методики викладання правознавства, Сумський державний педагогічний університет імені А.С. Макаренка

М. М. Бліхар, доктор юридичних наук, доцент, доцент кафедри конституційного та міжнародного права, Національний університет «Львівська політехніка» М. Л. Шелухін, доктор юридичних наук, професор, професор кафедри права та публічного адміністрування, Маріупольський державний університет

А. В. Хрідочкін, доктор юридичних наук, кандидат історичних наук, доцент, завідувач кафедри загально-правових дисциплін, Дніпровський гуманітарний університет

Г. О. Блінова, кандидат юридичних наук, доцент, доцент кафедри адміністративного права, процесу та адміністративної діяльності факультету підготовки фахівців для підрозділів превентивної діяльності, Дніпропетровський державний університет внутрішніх справ

Szabó Andrea (Сабо Андреа), доктор наук, професор, завідувач кафедри митної та фінансової діяльності факультету правоохоронної діяльності, Університет публічної служби (Угорська Республіка)

Л. Г. Удовика, доктор юридичних наук, професор, завідувач кафедри історії і теорії держави та права, Запорізький національний університет

О. П. Гетманець, доктор юридичних наук, професор, завідувач кафедри правового забезпечення господарської діяльності факультету № 6, Харківський національний університет внутрішніх справ

В. В. Шаблистий, доктор юридичних наук, доцент, професор кафедри кримінального права та кримінології факультету підготовки фахівців для органів досудового розслідування, Дніпропетровський державний університет внутрішніх справ

П. В. Хряпінський, доктор юридичних наук, професор, професор кафедри публічного права Інституту гуманітарних та соціальних наук, Національний технічний університет «Дніпровська політехніка»

Відповідальний редактор: С. В. Белькова

Редактори: С. В. Старкова

Технічний редактор: А. С. Лаптєва

Дизайнер обкладинки: Я. В. Зоська

\section{виходить щоквартально}

Журнал включено до Переліку наукових

фахових видань України (категорія «Б») з юридичних наук (спеціальності: 081. Право, 293. Міжнародне право) відповідно до Наказу МОН України від 17.03.2020 № 409 (додаток 1).

Журнал включено до міжнародної наукометричної бази Index Copernicus International (Республіка Польща)

\section{Засновник:}

Класичний приватний університет Свідоцтво Державного комітету інформаційної політики, телебачення та радіомовлення України про державну реєстрацію друкованого засобу масової інформації

Серія КВ № 14176-3147 ПР від 24.04.2008 p.

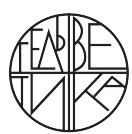

Видавництво та друк - Видавничий дім «Гельветика»

69002, м. Запоріжжя, вул. Олександрівська 84, оф. 414 Телесонни +38 (048) 70938 69,

+38(095) $9344828,+38$ (097) 7230608

E-mail: mailbox@helvetica.com.ua

Свідоцтво суб'єкта видавничої справи ДК № 6424 від 04.10.2018 p.

Журнал ухвалено до друку вченою радою Класичного приватного університету 24 червня 2020 р., протокол № 9

Усі права захищені. Повний або частковий передрук і переклади дозволено лише за згодою автора і редакції. При передрукуванні обов'язкове посилання на видання: Держава та регіони. Серія: ПРАВО. 2020. - № 3 (69).

Редакція не обов'язково поділяє думку автора і не відповідає за фрактичні помилки, яких він припустився.

Адреса редакції:

Класичний приватний університет 69002 , м. Запоріжжя, вул. Жуковського, 706. Телесон: (0612) 220-58-42, 8-067-7744481 Телефон/сракс: (0612) 63-99-73.

Здано до набору 15.06.2020.

Підписано до друку 26.06.2020. Формат $60 \times 84 / 8$. Ризографрія. Тираж 300 пр. Замовлення № 0920/253. 


\section{MICT}

\section{TЕОРІЯ ТА ІСТОРІЯ ДЕРЖАВИ I ПРАВА}

О. I. Зінсу

ДОМАШНЄ НАСИЛЬСТВО ЯК ПОЛІФОНІЧНИЙ ГЛИБИННИЙ КОНФЛІКТ

Л. М. Мозолюк-Боднар

ІСТОРИЧНО-ПРАВОВІ ЗАСАДИ РОЗВИТКУ МІСЦЕВИХ БЮДЖЕТІВ

\section{КОНСТИТУЦІЙНЕ ПРАВО; МУНІЦИПАЛЬНЕ ПРАВО}

Ю. М. Кириченко

СТАТУТ ТЕРИТОРІАЛЬНОЇ ГРОМАДИ ЯК ЕФЕКТИВНИЙ ЗАСІБ

ЛОКАЛЬНОЇ САМОРЕГУЛЯЦІЇ ТА САМОУПРАВЛІННЯ

А. Ю. Олійник

РЕАЛІЗАЦІЯ КОНСТИТУЦІЙНОЇ СВОБОДИ ОСОБИ

НА ПІДПРИЄМНИЦЬКУ ДІЯЛЬНІСТЬ У ПРОЦЕСІ ВИКОНАННЯ РОБІТ.

\section{ЦИВІЛЬНЕ ПРАВО І ПРОЦЕС}

\section{П. Д. Гуйван}

ПРАВОВЕ РЕГУЛЮВАННЯ ВІДПОВІДАЛЬНОСТІ

ЗА ДИФАМАЦІЮ, ІІЇ СПІВВІДНОШЕННЯ ЗІ СВОБОДОЮ СЛОВА

T. Я. РИм

ПАЙОВА (КООПЕРАТИВНА) ФОРМА ІНВЕСТУВАННЯ В БУДІВНИЦТВО.

Н. А. Сергієнко

ЗЛОВЖИВАННЯ ПРАВАМИ У ВИКОНАВЧОМУ ПРОЦЕСІ

\section{ГОСПОДАРСЬКЕ ПРАВО,} ГОСПОДАРСЬКО-ПРОЦЕСУАЛЬНЕ ПРАВО

В. О. Коверзнев

ПРАВОВА ХАРАКТЕРИСТИКА ДЕЯКИХ ЗАСАД

ГОСПОДАРСЬКОГО СУДОЧИНСТВА УКРАЇНИ.

В. В. Полішук

ТЕОРЕТИКО-ПРАВОВИЙ АНАЛІЗ ЗАСТОСУВАННЯ

МОДЕЛЕЙ МЕДІАЦІЇ В ГОСПОДАРСЬКИХ СПОРАХ

\section{АДМІНІСТРАТИВНЕ ПРАВО І ПРОЦЕС; ФIHAHCOBE ПРABO}

О. В. Агапова

КЛАСИФІКАЦІЯ НАПРЯМІВ ДІЯЛЬНОСТІ

У СФЕРІ ЕКСПЕРТНОГО ЗАБЕЗПЕЧЕННЯ

М. Є. Александров

АДМІНІСТРАТИВНО-ПРАВОВІ ЗАСАДИ ФУНКЦІОНУВАННЯ

БАЗИ ДАНИХ НЕБЕЗПЕЧНОЇ ПРОДУКЦІЇ UUVАGA.GOV.UА»

К. О. Кривошеєв

ПРАВООХОРОННІ ОРГАНИ ЯК СУБ' ЄКТИ ЗАБЕЗПЕЧЕННЯ

ФІНАНСОВОЇ БЕЗПЕКИ УКРАЇНИ. 
Е. О. Маркова

К ВОПРОСУ ОБ ОБЪЕКТИВИЗАЦИИ РЕЗУЛЬТАТОВ

АДМИНИСТРАТИВНОЙ ПРОЦЕДУРЫ.

Ю. Ю. Пустовіт, О. В. Запотоцька, В. О. Тімашов

СЬОГОДЕННЯ АДМІНІСТРАТИВНОЇ

ВІДПОВІДАЛЬНОСТІ ЮРИДИЧНИХ ОСІБ

Л. Т. Рябовол

ЗАБЕЗПЕЧЕННЯ БЕЗПЕКИ ЯК НАУКОВА ПРОБЛЕМА:

РЕАЛІЗАЦІЯ СИСТЕМНОГО ПІДХОДУ ДО ДОСЛІДЖЕННЯ.

І. В. Слободенюк

АДМІНІСТРАТИВНІ ПОСЛУГИ В ДІЯЛЬНОСТІ

СЕРВІСНИХ ЦЕНТРІВ МВС УКРАЇНИ:

ПОНЯТТЯ, ВИДИ ТА КЛАСИФІКАЦІЯ.

О. В. Сударенко

ДОБРОВІЛЬНІ МЕТОДИ МОБІЛІЗАЦІЇ КОШТІВ

ДО ПУБЛІЧНИХ ФОНДІВ: ФІНАНСОВО-ПРАВОВИЙ АСПЕКТ

C. C. Федорімев

ДІЯЛЬНІСТЬ ЦЕНТРІВ НАДАННЯ АДМІНІСТРАТИВНИХ ПОСЛУГ:

ПРОБЛЕМНІ ПИТАННЯ ТА ШЛЯХИ ЇХ ВИРІШЕННЯ

\section{КРИМІНАЛЬНЕ ПРАВО ТА КРИМІНОЛОГІЯ; КРИМІНАЛЬНО-ВИКОНАВЧЕ ПРАВО}

T. М. Беркій

ШЛЯХИ ВДОСКОНАЛЕННЯ ЗАСОБІВ ПОПЕРЕДЖЕННЯ

ТА ПРОТИДІЇ СЕПАРАТИЗМУ В УКРАЇНІ

Д. А. Коваленко

ПРОБЛЕМНІ ПИТАННЯ ОБ'ЄКТИВНОЇ СТОРОНИ

КРИМІНАЛЬНОГО ПРАВОПОРУШЕННЯ ЗА ПЕРЕШКОДЖАННЯ

З'ЯВЛЕННЮ СВІДКА, ПОТЕРПІЛОГО, ЕКСПЕРТА, ПРИМУШУВАННЯ ЇХ

ДО ВІДМОВИ ВІД ДАВАННЯ ПОКАЗАНЬ ЧИ ВИСНОВКУ

\section{КРИМІНАЛЬНИЙ ПРОЦЕС ТА КРИМІНАЛІСТИКА; СУДОВА ЕКСПЕРТИЗА}

Ю. П. Аленін, О. О. Торбас

СПІВВІДНОШЕННЯ ПРОЦЕСУАЛЬНОЇ САМОСТІЙНОСТІ

ТА РОЗСУДУ СЛІДЧОГО У КРИМІНАЛЬНОМУ ПРОЦЕСІ УКРАЇНИ

С. З. Булик-Верхола, А. О. Верхола

ОСОБЛИВОСТІ КРИМІНАЛЬНОГО

ПРОЦЕСУАЛЬНОГО ЗАХИСТУ ПРЕСИ В УКРАЇНІ.

М. Д. Денисовський, І. О. Томчук, Л. В. Петруник

ПРОЦЕСУАЛЬНІ АСПЕКТИ ПРОВЕДЕННЯ ОБШУКУ

ЯК ОДНОГО ІЗ ЗАСОБІВ ОТРИМАННЯ ДОКАЗІВ

У КРИМІНАЛЬНОМУ ПРОВАДЖЕННІ

Ю. В. Шапошников

СУБЪЕКТИВНАЯ СТОРОНА НЕПОВИНОВЕНИЯ

(СТ. 402 УК УКРАИНЫ). 


\section{СУДОУСТРІЙ; ПРОКУРАТУРА ТА АДВОКАТУРА}

I. M. Legan, K. S. Bondarenko

FEATURES OF THE FREE LEGAL AID SYSTEM

IN UKRAINE AND THEEUROPEAN UNION COUNTRIES.

\section{ФІЛОСОФІЯ ПРАВА}

Я. Я. Мельник

АНТРОПОГЕНЕЗ МІГРАЦІЙНИХ ПРОЦЕСІВ

У ПРИЗМІ ПОСТМОДЕРНУ СОЦІАЛЬНОГО ПРАВА 


\section{CONTENTS}

\section{THEORY AND HISTORY OF STATE AND LAW}

Zinsu O. I.

DOMESTIC VIOLENCE AS A POLYPHONIC DEEP CONFLICT ......................................

Mozolyuk-Bodnar L. M.

HISTORICAL AND LEGAL FOUNDATIONS

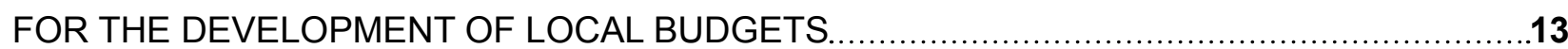

\section{CONSTITUTIONAL LAW; MUNICIPAL LAW}

Kyrychenko Yu. M.

STATUTE OF THE TERRITORIAL COMMUNITY AS AN EFFECTIVE MEANS

OF LOCAL SELF-REGULATION AND SELF-GOVERNMENT.

Oliynyk A. Yu.

REALIZATION OF THE CONSTITUTIONAL FREEDOM

OF A PERSON FOR ENTREPRENEURIAL ACTIVITY

IN THE PROCESS OF PERFORMANCE OF WORKS.

\section{CIVIL LAW AND PROCESS; FAMILY LAW}

Guyvan P. D.

LEGAL REGULATION OF LIABILITY FOR DEFAMATION,

ITS RELATIONSHIP WITH FREEDOM OF SPEECH.

Rym T. Ya.

SHARE (COOPERATIVE) FORM OF INVESTMENT IN CONSTRUCTION.

Sergiienko N. A.

MISUSE OF RIGHTS IN EXECUTIVE PROCESS

\section{LABOR LAW; ECONOMIC AND PROCEDURAL LAW}

Koverznev V. O.

LEGAL CHARACTERISTICS OF CERTAIN PRINCIPLES

OF ECONOMIC JUDICIARY OF UKRAINE.

Polishchuk V. V.

THEORETICAL AND LEGAL ANALYSIS OF MEDIATION MODELS APPLICATION

IN ECONOMIC DISPUTES

\section{ADMINISTRATIVE LAW AND PROCESS; FINANCIAL LAW}

Agapova O. V.

CLASSIFICATION OF DIRECTIONS OF ACTIVITIES

IN THE SPHERE OF EXPERT ENSURING OF JUSTICE.

Aleksandrov M. Ye.

ADMINISTRATIVE AND LEGAL FOUNDATIONS OF THE FUNCTIONING

OF THE DATABASE OF NON-SAFETY PRODUCTS "UVAGA.GOV.UA".

Kryvosheyev K. O.

LAW ENFORCEMENT AUTHORITIES AS SUBJECTS

OF FINANCIAL SECURITY OF UKRAINE. 
Markova E. O.

TO THE QUESTION OF OBJECTIVATION

OF THE RESULTS OF THE ADMINISTRATIVE PROCEDURE

Pustovit Yu. Yu., Zapototska O. V., Timashov V. O.

CURRENT ADMINISTRATIVE RESPONSIBILITY

OF LEGAL ENTITIES.

Ryabovol L. T.

SECURITY ASSURANCE AS A SCIENTIFIC PROBLEM:

IMPLEMENTATION OF A SYSTEMATIC APPROACH TO RESEARCH.

Slobodeniuk I. V.

ADMINISTRATIVE SERVICES IN OPERATION SERVICE CENTERS

OF THE MIA OF UKRAINE: CONCEPT, TYPES AND CLASSIFICATION

Sudarenko O. V.

VOLUNTARY MONEY MOBILIZATION METHODS TO PUBLIC FUNDS:

FINANCIAL AND LEGAL ASPECT.

Fedorishchev S. S.

ACTIVITIES OF CENTERS FOR PROVISION

OF ADMINISTRATIVE SERVICES:

PROBLEM ISSUES AND WAYS OF THE SOLUTION

\section{CRIMINAL LAW AND CRIMINOLOGY; CRIMINAL EXECUTIVE LAW}

Berkii T. M.

WAYS TO IMPROVE THE MEANS OF PREVENTING

AND COMBATING SEPARATISM IN UKRAINE.

Kovalenko D. A.

PROBLEM ISSUES OF THE OBJECTIVE SIDE

OF THE CRIMINAL OFFENSE FOR OBSTACLING THE APPEARANCE

OF A WITNESS, A VICTIM EXPERT, FORCING THEM TO REFUSE

TO GIVE EVIDENCE OR OPINIONS

\section{CRIMINAL PROCEDURE AND FORENSIC SCIENCE;}

LEGAL EXPERTISE

Alenin Yu. P., Torbas O. O.

INTERRELATION BETWEEN PROCEDURAL INDEPENDENCE

AND DISCRETION OF INVESTIGATION IN THE CRIMINAL PROCESS

OF UKRAINE

Bulyk-Verkhola S. Z., Verkhola A. O.

THE FEATURES OF CRIMINAL PROCEDURAL PROTECTION

OF THE PRESS IN UKRAINE

Denysovskyi M. D., Tomchuk I. O., Petrunyk L. V.

PROCEDURAL ASPECTS OF THE CONDUCTING

A SEARCH AS ONE OF THE MEANS OF OBTAINING EVIDENCE

IN CRIMINAL PROCEEDINGS.

Shaposhnikov Yu. V.

THE SUBJECTIVE SIDE OF DISOBEDIENCE

(ART. 402 OF THE CRIMINAL CODE OF UKRAINE). 


\section{JUDICIARY; PROSECUTION AND ADVOCACY}

Legan I. M., Bondarenko K. S.

FEATURES OF THE FREE LEGAL AID SYSTEM

IN UKRAINE AND THEEUROPEAN UNION COUNTRIES.

\section{PHILOSOPHY OF LAW}

Melnyk Ya. Ya.

ANTHROPOGENESIS OF MIGRATION PROCESSES

IN THE PRISM OF POSTMODERN SOCIAL LAW 


\title{
ТЕОРІЯ ТА ІСТОРІЯ ДЕРЖАВИ I ПРАВА
}

\author{
УДК 340.13:343.5/.6:316.6:159.9 \\ DOI https://doi.org/10.32840/1813-338X-2020.3.1
}

O. I. 3інсу

аспірантка відділу докторантури та ад'юнктури Національної академії внутрішніх справ

\section{ДОМАШНЄ НАСИЛЬСТВО ЯК ПОЛІФОНІЧНИЙ ГЛИБИННИЙ КОНФЛІКТ}

Метою наукової статmі є дослідження френомена домашнього насильства як поліфонічного глибинного конфллікту, в основі якого лежить інтегрований комплекс елементів макросистеми й мікросистеми. Наголошено, що трансорормаційні процеси в сучасному вітчизняному соціальному просторі неодмінно позначаються на зміні парадигми морально-правової поведінки в суспільних і приватних стосунках і, зокрема, у сфері сім'ї, побуті, родині та вимагають вироблення дієвих заходів розв'язання конфрлікту домашнє насильство. З'ясовано, що детермінантами домашнього насильства виступають чинники біологічного, соціального, психологічного, культурного характеру, що відображено, відповідно, в різних теоріях насильницької поведінки: соціокультурній; системно-сімейній; індивідуально-психологічній. Визначено концептуальні положення циклічності домашнього насильства. Відокремлено суспільно-небезпечний характер проявів домашнього насилля та, відповідно, викладено статистичні дані структурних сегментів осіб, які зазнали впливу домашнього насилля. Встановлено, що соціально-психологічні передумови неправомірної поведінки та домашнього насильства корелюють з індивідуальною психологічною вразливістю особистості та ступенем індикаторів глибинного конфрлікту. Обгрунтовано значення психологічної несумісності та правосвідомості у фрормуванні, розвитку, становленні та розв'язанні глибинного конфлікту домашнє насильство. Виявлено, що глибинний конфлікт, яким є домашнє насилля, вміщує в собі фрункціональне ядро полярності: конструктивізму та деструкції (деконструктивізму). Відповідно, особливої значущості в запобіганні та протидії домашньому насильству як поліфонічному глибинному конфрлікті з-поміж інших складників набуває розвиток критичного мислення та особистісних чинників правомірного спрямування. Також велику роль відіграють механізми соціального захисту та психологічно-правовий супровід соиіально вразливих категорій населення, які зазнали впливу домашнього насильства. На основі проведеного дослідження сформовано висновки й пропозиції щодо подальших міждисциплінарних теоретико-прикладних досліджень феномена домашнього насильства.

Ключові слова: домашне насильство, конфрлікт, держава, правосвідомість, правова культура, психологічна несумісність, співзалежність.

Постановка проблеми. В сучасних умовах інтеграції України в європейське товариство особливої актуальності набуває проблематика домашнього насильства та пов'язані з нею трансформаційні тенденції в суспільному та приватному бутті. Гетерогенез культурного світу, фррагментарність і динамічність суспільних цінностей, специфріка посттоталітарної амбівалентності та зближення правових систем світу неодмінно позначаються на зміні соціальної орієнтації та ідеалів з осмисленням нових соціальних реалій поліфонічності домашнього насильства, що зумовлює актуальність наукових пошуків у сорері теоретико-прикладних інтенцій домашнього насилля як поліфонічного глибинного конфрлікту.

Мета статті - аналіз феномена домашнього насильства як поліфонічного глибинного конфрлікту.

Аналіз останніх досліджень і публікацій. Різні аспекти парадигми морально-правової поведінки в сім'ї, родині, побуті привертали 
увагу вчених, фрілософрів, практиків, законодавців упродовж усього розвитку суспільства та формування, становлення інституту права і держави. Натомість особливий інтерес у вітчизняному соціально-правовому просторі до цього наукового напряму зріс після набрання чинності Закону України «Про запобігання та протидію домашньому насильству» [1] та ухвалення нормативно-правових актів, пов'язаних з організаційно-правовим механізмом реалізації положень зазначеного Закону.

На цьому тлі вирізняються наукові пошуки сучасних вітчизняних учених, а саме: окремі аспекти альтернативного вирішення спорів під час урегулювання сімейних конфлліктів $(\mathrm{H}$. Бондаренко-Зелінська, 2016); поняття, сутність і причини виникнення насильства в сім'ї: (І. Ботнаренко (2016); міжпоколінний конфлікт як спосіб взаємодії представників різних поколінь у сім'ї (А.Галичанська (2014); психологічні чинники конфліктів у молодій сім'ї (Т. Зозуль, 2014); історично-правові аспекти протидії насильству в сім'ї (І. Ієрусалімов, О. Литвинчук, В. Ієрусалимов, 2019); причини латентності насильства в сім'ї (М. Качинська, 2016); причини виникнення, попередження, врегулювання сімейного конфрлікту (3. Кругл, 2017); особливості та специфріка конфліктів у сім'ї (Р. Квас, 2016); запобігання побутовому насильству: кримінологічні засади (О. Литвинов,2014); структурно-динамічні особливості та соціально-психологічні засоби корекції неконструктивних життєвих стратегій подружжя (О. Морозова, 2018); аналіз сутності побутового насильства як соціально-психологічного явища (М. Троїцька, 2016); соціально-правові чинники протидії домашньому насильству (С. Чернета, 2018); насильство в сім'ї як суспільне явище (І. Шаповал, 2016).

Кожний із дослідників, із-поміж іншого, викладав своє бачення, свій світогляд, власні наукові інтерпретації, теоретичні конструкції тощо. Наприклад, Н. Бондаренко-Зелінська висловлює позицію, що найбільш ефективними під час розв'язання сімейних конфліктів $є$ способи альтернативного розв'язання спорів («Alternative Dispute Resolution») [2, с. 158]. Т. Зозуль дотримується поглядів, що детермінантами психологічних розладів у стосунках молодого подружжя $€$ психологічна неготовність до взаємодії, конфоліктність через невміння конструктивно спілкуватися та розв'язати конфрліктні ситуації, а також неусвідомленість відповідальності за можливі наслідки конфрлікту [3, с. 7].
Серед сучасних закордонних учених, дослідників проблематику домашнього насильства вивчали Т. Айох (Т. Ayouch,2018), Р. Андріамандросо (R. Andriamandroso, 2019); К. Ґарсія (K. Garcia, 2017), E. Герман (E. Herman, 2019), I. Коте (I. Côté, 2017), М.Хуот (M. Huot,2016), Ф. Оуелет (F. Ouellet, 2019), Л. Лофер (L. Laufer, 2018), Г. Патард (G. Patard,2019), Г. Пір'є (G. Perrier, 2018), Д. Пeppo (D. Perreault,2018), Аделаїда Тангуй (А. Tanguy, 2016), М.Л. Тремблей (M.L. Tremblay, 2017) та інші.

Зокрема, еволюцію практики створення, фрункціонування притулку для жінок, жертв домашнього насильства у Квебеку досліджувала у своїй дисертаційній роботі канадська дослідниця І. Коте (I. Côté, 2017) [6]; тематику подружнього насильства, сім'ї та втручання розглядали в співавторстві Л. Лофер та T. Aйох (L. Laufer \& T. Ayouch, 2018) [7]; дослідження сімейної медіації за наявності домашнього насильства: скринінг, практики втручання, виклики та проблеми привернули увагу М. Гуот (М. Huot, 2016) [8]; подружнє насильство: форми, види, дослідження та профілактику вивчали вчені Фредерік Оуелет і Гізела Патард (G. Patard \& F. Ouellet, 2019) [9].

Утім, попри численні публікації з проблематики домашнього насильства, питання інтенцій домашнього насилля як поліфонічного глибинного конфрлікту з використанням потенціалу міждисциплінарного підходу не отримало достатнього теоретичного розроблення та висвітлення і не виступало предметом спеціальних досліджень, що актуалізує значущість обраної теми дослідження.

Виклад основного матеріалу. Сучасний стан суспільно-історичного поступу процесів державотворення і правотворення в Україні втілює стратегії розбудови правової держави, фрормування успішного громадянського суспільства та передбачає реалізацію значних трансформаційних реформ у суспільних і приватних відносинах. Зазначене неодмінно позначається на переосмисленні заданих тоталітарним режимом правил поведінки в сім'ї, побуті, родині. Особливої гостроти при цьому набуває проблематика домашнього насильства, розв'язання якої насамперед полягає в викоріненні дискримінаційних стереотипних уявлень щодо морально-правових норм поведінки та усвідомлення, сприйняття нових зразків моделей поведінки, заснованих на аксіологічних настановах демократичного суспільства людиноцентричної моделі буття. 
Складний і суперечливий феномен домашнього насильства являє собою інтегрований комплекс елементів макросистеми й мікросистеми, який містить чинники біологічного, соціального, психологічного, культурного характеру, що відображено відповідно в різних теоріях насильницької поведінки: соціокультурній, системно-сімейній, індивідуально-психологічній. Кожна із зазначених теорій охоплює певні підходи та сегменти соціальності, спільними для яких виступає наявність глибинного конфрлікту. В структурній основі поліфонічності конфрлікту домашнього насильства з-поміж інших складників лежить конфлікт цілей, конфрлікт пізнання, конфолікт почуттів, що в поєднані з низьким рівнем правової культури, деформацією правосвідомості (правовим нігілізмом, дилетантизмом), психопатологічними розладами особистості створюють надалі ризик суспільно-небезпечного діяння.

Наявність суперечностей за розбіжності інтересів і ціннісних установок спонукає до нав'язування свого бачення, своїх принципів, стереотипів, які фрормують модель поведінки учасників конфрліктної взаємодії. Істотною ознакою досліджуваного поняття простежується агресія, неповага до прав і свобод іншої людини, пронизливе почуття ненависті, жадоба моральної, психологічної, економічної влади, намагання приховати особисту неповноцінність шляхом нав'язування власної влади над членами сім'ї, родини; застосування різних фрорм контролю та маніпулювання іншими; високий рівень оцінних суджень і наклеювання ярликів, поряд із низьким рівнем психічної саморегуляції, комунікативної культури. При цьому всі учасники конфрлікту у сфрері домашнього насильства як безпосередньо, так і опосередковано впливають один на одного.

Поліфонічність домашнього насильства вирізняється циклічністю, що розгортається в часі й в просторі. Історія циклічності домашнього насилля має чотири фрази:

1. На початку (перший етап) простежується накопичення напруги, супротивність, фрормування невдоволення, роздратованості, назрівання конфліктної ситуації. 2. Далі йде кульмінаційний етап. Стан гострого безконтрольного емоційно-психологічного стану, неодмінним елементом якого $€$ вибух епізодів насильства (фрізичного, економічного, психологічного, сексуального). 3. Третя фаза проходить під назвою так званого медового місяця. Зазначена фаза характеризується теплими відносинами, показовістю «начебто щирого каяття» та гарних відносин. Спостерігається прийняття провини.
Лунають обіцянки виправлення та подальшої «слухняної поведінки». 4. Після періоду «медового місяця» наступає стадія невдоволення, непорозуміння, розчарованість, почуття, що «нічого не змінилося», він (вона) «знову ображає», простежується загострення суперечностей, невдоволення, залучення нових учасників, поява нових та (або) розгортання усталених нерозв'язаних фррагментів глибинного конфрлікту. Чільне місце в наростанні міжособистісного та внутрішнього стану невдоволення учасників конфрлікту займає психологічна несумісність, яка містить індивідуально-психологічні складники, ціннісні орієнтації, рівень домагань, правову культуру, світогляд, соціальну роль.

Аналіз проведених спостережень, анкетування, опитувань підтверджує роль психологічної несумісності та рівня правосвідомості в розгортанні конфрлікту. Зокрема, підчас психологічної несумісності на ґрунті особистісних неприязних стосунків і наростання суперечностей спрацьовує закон ескалації конфрліктогенів. При цьому прояв конкретного фрагмента (епізоду) домашнього насильства залежить від взаємопов'язаних, взаємозалежних індикаторів економічного, морального, психологічного зрізів. Формами психологічних конфрліктогенів можуть бути: погрози, приниження, сарказм, деструктивна критика, газлайтинґ, принизливі судження, повчання, докори та інше. Кожна повторність циклу домашнього насильства має тенденцію до поглиблення сформованого глибинного конфрлікту. 3 плином часу фррагментарність епізодів насилля набуває звичногодля сім'їстану співзалежності учасників конфлікту, засвідчуючи адаптовану роками стереотипну неправомірну поведінку, втрату контролю над власною поведінкою та незворотний процес деградації особистості, відповідно, створюючи вірогідність розвитку «конфлікту вітального значення».

У цьому контексті доцільно згадати й про статистичні дані. Наприклад, «структурний розподіл жертв від домашнього насильства, що $є$ небезпечним для життя, за статтю має такий вигляд: жінки: дружина (співмешканка) - кваліфіковані вбивства $(51,7 \%)$, умисні вбивства $(29,9 \%)$, тяжкі тілесні ушкодження (34,5\%); мати (сестра) - 7,5, 7 і 4,4\% відповідно; донька, баба, теща $-5,5,4$ і 2,9\% відповідно; коханка, приятелька, сусідка та інші особи - 4,1, 12,1 і 5,1\% відповідно; чоловіки: чоловік (співмешканець) -15,8, 13,1 і 9,9\% відповідно; син (брат) - 8,8, 10,5 і 16,8\% відповідно; приятель, знайомий, сусід та інші особи - 21, 
8,1 і 26,4\% відповідно» [4, с. 138]. При цьому, як зазначає О. Ткаленко, жінки, що потерпають від насильства в подружніх стосунках, часто схильні до несвідомого «відігравання образ» на власних дітях, яке проявляється у зневажанні потребами дітей (зокрема, життєво необхідними) [5, с. 27].

Тож «серед причин насильства в сім'ї щодо дітей, які називали опитані нами працівники органів публічної адміністрації, такі: 39,4\% пов'язують це явище зі свідомим методом виховання; 33,3\% - 3 матеріальною нестабільністю; $27,3 \%$ - 3 нездоровим способом життя членів сім'ї. При цьому 41,4\% опитаних зазначили, що батьки застосовують насильство до своїх дітей тому, що вважають, що це найкращий метод виховання; $36 \%$ - батьки не знають інших методів виховання; 27,6\% - коли в батьків поганий настрій, вони намагаються відвести злість. Загалом причини формування насильницьких взаємин у родині не вичерпуються будь-яким одним фрактором. Розвиток насильницьких стосунків $€$ наслідком їхньої сукупності» [4, с. 25]. Також досліджено вплив дитячих казок на формування насильницької моделі поведінки в дітей. Наприклад, О. Ткаленко зазначає, що аналіз дитячих казок, за допомогою яких формується свідомість дітей і прививаються певні соціальні норми, приводить до висновку про поширення у них елементів домашнього насильства, яке доволі часто сприймається як належне [5, с. 24-25].

Пильної уваги дослідника конфлікту також потребує сегмент соціально вразливих категорій населення. Це насамперед соціально малозахищені родини, розлучені члени сім'ї, діти, безпритульні особи, особи з обмеженими можливостями, особи похилого віку, трудові мігранти, члени інтернаціональних сімей та інші соціально вразливі категорії населення, які за станом безпорадності, патології здоров'я, економічно-фрінансової залежності неспроможні гідно відстояти та захистити свої законні права, інтереси від неправомірних діянь членів сім'ї, родини. Через це серед складників конструктивного розв'язання проблематики домашнього насильства належне місце також мають посідати державні гарантії кількісних та якісних параметрів соціального забезпечення зазначених соціальних сегментів.

Також доцільно наголосити, що глибинний конфлікт, яким є домашнє насилля, вміщує в собі функціональне ядро полярності: конструктивізму та деструкції. 3 огляду на зазначене вкрай важливим $€$ наявність уміння та готовності віднайти потенційні ресурси особистості, спрямовані на підвищення рівня розвитку критичного мислення, рівня самоконтролю, незалежності й спроможності самостійного опанування методами та прийомами конструктивного розв'язання конфрліктної ситуації ще на стадіях зародження чи інтенсивного формування домашнього насилля. Це, відповідно, потребує зміни світогляду й вироблення навичок правомірного з гуманістичних позицій розв'язання конфлікту та беззаперечного відсторонення від стереотипних дискримінаційних неправомірних насильницьких рішень і діянь (дій чи бездіяльності) у сімейній (родиннопобутовій) рольовій взаємодії.

Висновки і пропозиції. Отже, глибинний конфрлікт у сфрері домашнього насильства як прояв неправомірної поведінки потребує ретельних теоретико-прикладних досліджень, що передбачають: наукові пошуки генези домашнього насильства; аналіз правових санкцій на прояви домашнього насильства; розроблення програми конструктивного психологічно-правового розв'язання конфлікту й вироблення чіткого дієвого соціально-правового захисту осіб, які зазнали впливу домашнього насилля.

\section{Список використаної літератури:}

1. Про запобігання та протидію домашньому насильству: Закон України від 7 грудня 2017 р. № 2229-VII. Відомості Верховної Ради (BВP). 2018. № 5. Ст. 35. URL: http://zakon.rada.gov.ua (дата звернення: 21.07.2020).

2. Бондаренко-Зелінська Н.Л. Окремі аспекти альтернативного вирішення спорів при врегулюванні сімейний конфрліктів. Приватне право і підприємництво. 2016. Вип. 15. С. 158-162. URL: http://nbuv.gov.ua/UJRN/2016_15_41 (дата звернення: 21.07.2020).

3. Зозуль Т.В. Психологічні чинники конфліктів у молодій сім'ї. Вісник Харківського національного педагогічного університету імені Г.С. Сковороди. Психологія. 2014. Вип. 47. C. 58-65. URL: http://nbuv.gov.ua/UJRN/VKhnpu_ psykhol_2014_47_9 (дата звернення: 21.07.2020).

4. Кузнецов М. Віктимологічний портрет жертви домашнього насильства, що $€$ небезпечним для життя. Вісник Пенітенціарної асоціації України. Київ, 2019. № 1 (7). С. 136-144. DOI: https://doi.org/10.34015/2523-4552.2019.1.12. URL: http://nbuv.gov.ua/UJRN/bpau_2019_1_14 (дата звернення: 21.07.2020).

5. Ткаленко О.М. Адміністративно-правове забезпечення діяльності органів публічної адміністрації щодо попередження насильства в сім'ї відносно дітей : дис. ... канд. юрид. 
наук: 12.00.07; Одеський державний університет внутрішніх справ. Одеса, 2016. URL: https://oduvs.edu.ua/uploads/2016/09/dus_ tkalenko (дата звернення: 21.07.2020).

6. Isabelle Côté L'évolution des pratiques en maison d'hébergement pour femmes victimes de violence conjugale au Québec I Côté. 2017. papyrus.bib. umontreal.ca URL: https://www.puq.ca/catalogue/ livres (дата звернення: 21.07.2020).

7. Laurie Laufer, Thamy Ayouch. Violences conjugales, famille, vulnérabilité. Topique-Revue freudi-enne, L'Esprit du temps. 2018. № 143 (2). P. 151-167. 10.3917/top.143.0151.hal-02530091. URL: https://hal-univ-diderot.archives-ouvertes.fr/ hal-02530091 (дата звернення: 21.07.2020).
8. Madeleine Huot L'intervention en médiation familiale en présence de violence conjugale: dépistage, pratiques d'intervention, défis et préoccupations. Thesis or Dissertation. par Huot, Madeleine Université de Montréal. Canada, 2016. URL: http://hdl.handle.net/1866/16230. URL: papyrus.bib.umontreal.ca/ha... (дата звернення: 21.07.2020).

9. Guisela Patard, Frédéric Ouellet Violence conjugale: formes, types, recherche et prévention. Université de Montréal, Montréal, Quebec, Canada. Violence conjugale: formes, types, recherche et prévention. G Patard, F Ouellet, 2019. papyrus. bib.umontreal.ca URL: www.researchgate.net/ 33343... (дата звернення: 21.07.2020).

\section{Zinsu O. I. Domestic violence as a polyphonic deep conflict}

The aim of the scientific article is to study the phenomenon of domestic violence as a polyphonic deep conflict based on an integrated set of elements of the macro system and micro system. It is emphasized that the transformation processes in the modern domestic social space inevitably affect the paradigm shift of moral and legal behavior in public and private relations, and in particular, in the family, life, family and require effective measures to resolve the conflict "domestic violence". It was found that the determinants of domestic violence are factors of biological, social, psychological, cultural nature, which is reflected, respectively, in various theories of violent behavior: sociocultural; systemfamily; individual psychological. The conceptual provisions of the cyclical nature of domestic violence are determined. The socially dangerous nature of domestic violence is highlighted and, accordingly, statistical data of structural segments of persons affected by domestic violence are presented. It is established that socio-psychological preconditions of illegal behavior and domestic violence correlate with individual psychological vulnerability of the individual and the degree of indicators of deep conflict. It was found that the deep conflict, which is domestic violence, contains a functional core of polarity: constructivism and destruction (de-constructivism). Accordingly, the development of critical thinking and personal factors of lawful direction acquires special significance in preventing and counteracting domestic violence as a polyphonic deep conflict among other components. Mechanisms of social protection and psychological and legal support of socially vulnerable categories of the population affected by domestic violence also play an important role. On the basis of the conducted research the conclusions and offers concerning the further interdisciplinary theoretical and applied researches of a phenomenon of domestic violence are formed.

Key words: domestic violence, conflict, state, legal awareness, legal culture, psychological incompatibility, codependency. 


\section{Л. М. Мозолюк-Боднар}

кандидат юридичних наук, доцент кафедри правових та інформаційних технологій Хмельницького інституту соціальних технологій Відкритого міжнародного університету розвитку людини «Україна»

\section{ІСТОРИЧНО-ПРАВОВІ ЗАСАДИ РОЗВИТКУ МІСЦЕВИХ БЮДЖЕТІВ}

Устатті розглянуто історично-правові аспекти виникнення місцевих бюджетів та етапи становлення бюджетної системи України та місцевих бюджетів зокрема. Зазначено, що для розвитку місцевих бюджетів України передував складний процес фоормування фрінансової системи України, яка тривалий час була під впливом інших держав. Лише з моменту отримання незалежності стало можливим формування власної економічної системи. Однак всі ці процеси відбувались за умов вимушеного прискорення, більшість законодавчих актів були неефективними, суперечливими, фрінансова система наділялася ознаками притаманними командно-адміністративній економіці, що не найліпшим чином сприяло розвитку місцевих бюджетів. Тому для вирішення різних проблем, що стосуються соціально-економічного розвитку територіальних громад, сьогодні запроваджена та активно втілюється в життя адміністративно-територіальна реформа, в контексті якої відбувається децентралізація місцевих бюджетів, реформування законодавства.

Визначено, що головна мета реформи децентралізації полягає в передачі значної частини повноважень та бюджетів від державних органів органам місцевого самоврядування, а також передбачає три рівні: фрінансова децентралізація, об'єднання громад і ухвалення необхідних змін до чинного законодавства.

Акцентовано, що Верховна Рада України ухвалила постанову № 3650 ЄПро утворення та ліквідацію районів», якою реформується субрегіональний рівень адміністративно-територіального устрою України. Цим документом замість наявних в Україні 490 районів створюється 136 укрупнених. Реформа забезпечить відповідність системи адміністративно-територіального устрою районного рівня України сучасним вимогам та європейським стандартам.

Рефрорма місцевого самоврядування повинна вирішити багато найважливіших проблем, зокрема й щодо наповнення місцевих бюджетів, особливо актуальне це питання в умовах карантину. Однак усе це має здійснюватися в межах цілісного пакету політичних, економічних, соціальних реформ, спрямованих на перетворення України в сучасну європейську країну.

Ключові слова: бюджет, місцевий бюджет, децентралізація місцевих бюджетів, бюджетна система, субрегіональний рівень адміністративно-територіального устрою України.

Постановка проблеми. В останні роки в Україні назріла необхідність бюджетної децентралізації для повного задоволення потреб населення в кожному регіоні. Реформування місцевих бюджетів зміцнить їх фрінансову основу та посилить вплив на соціально-економічний розвиток та поліпшення добробуту населення України. Тому дослідження історично-правових засад розвитку місцевих бюджетів набуває особливої актуальності та $є$ необхідним для ефективності подальшого рефрормування публічного управління в Україні. Адже досліджуючи ті чи інші суспільні явища, необхідно передбачати їх еволюцію, а це можливо зробити тільки з урахуванням попереднього досвіду розвитку. Історичний підхід до аналізу зазначеної проблематики поглиблює пізнавальний процес, робить його комплексним і ґрунтовним, сприяє переосмисленню та подальшому вивченню питань, що стосуються розвитку місцевих бюджетів, які $€$ обов'язковими, важливими і необхідними атрибутами державності. 
Аналіз останніх досліджень і публікацій. Питання щодо історично-правових засад розвитку місцевих бюджетів активно досліджували не лише з правової точки зору, але й з точки зору економічного аналізу (Г.В. Возняк, О.Б. Жихор, І.С. Микитюк, Г.Г. Молодченко, О.І. Тулай та ін.). Із правової позиції цій проблематиці присвятили наукові доробки Д.О. Білінський, Л.К. Воронова, О.А. Музика-Стефранчук, Ю.В. Пасічник, О.В. Покатаєва, Ю.Ю. Пустовіт, О.Ю. Салманова, І.В. Солошкіна, Н.В. Сидорова, О.В. Чинчин та ін.

Міждисциплінарне дослідження даного питання $є$ цілком виправданим та свідчить про практичне значення для подальшого процесу децентралізації державного управління.

Постановка завдання. Метою статті $\epsilon$ дослідження історично-правових засад розвитку місцевих бюджетів у процесі децентралізації та реформування системи публічної влади.

Виклад основного матеріалу дослідження. Конституцією України визначено, що для повноцінного функціонування інституту місцевого самоврядування необхідне його матеріальне та фінансове забезпечення, основу якого складають місцевий бюджет і майно об'єктів комунальної форми власності, які перебувають у розпорядженні органів влади, а також земельні та природні ресурси [1]. Місцеві бюджети - це найважливіша ланка в системі фінансових планів, які використовуються для регулювання соціально-економічних і фрінансово-правових завдань певної території. Досліджуючи історично-правові аспекти виникнення місцевих бюджетів, Т.Г. Молодченко розглядає їх у декількох аспектах: 1) як організаційну форму мобілізації частини фрінансових ресурсів у розпорядженні місцевих органів самоврядування; 2) як систему фрінансових відносин, що складаються між місцевими та державним бюджетами, а також у середині місцевих бюджетів; 3) як правовий акт, згідно з яким виконавчі органи влади отримують легітимне право на розпорядження певними фондами грошових ресурсів; 4) як кошторис доходів і видатків відповідного місцевого органу чи самоврядування; 5) як економічну категорію, тому що бюджет $є$ атрибутом будь-якої самостійної територіальної одиниці, наділеною відповідним правовим статусом [2].

Поняття «бюджет» має давню історію. Первісно цей термін походить від давньофранцузького bouge (сумка) та зменшеного bougette (гаманець). Надалі слово було запозичене англійською мовою і стало відомо як budget - спочатку з тим самим звичайним побутовим зна- ченням (гаманець), а потім «бюджет» почав використовуватися й як один із законодавчих термінів англійського парламенту. Як зазначає Л.К. Воронова, в англійському законодавчому органі закріпилася така процедура, коли «під час вотування Палатою громад субсидій королю Канцлер казначейства відкривав сумку, в якій зберігалися документи. Цей акт звався відкриттям «бюджету», а назва сумки перейшла на документ. Наприкінці XVIII століття термін budget повернувся до Франції, а з XIX століття офріційно набув значення державного розпису доходів і видатків [3, с. 9]. Тим самим мовна одиниця «бюджет» набула свого публічно-правового фрінансового значення [4, с. 12].

Взагалі категорію «бюджет» можна дослідити в багатьох аспектах. Передусім мова йде про правовий його бік, водночас бюджет являє собою й економічну, й загальносуспільну категорію, які пов'язані між собою. Проте первісне розуміння бюджету було саме правовим, оскільки він виник саме як законодавчий термін. Л.К. Воронова підкреслює, що «бюджет як правова категорія виникає разом із представницькими органами державної влади, які набувають права періодично схвалювати державні видатки і доходи. До цього часу держави приймають бюджет у законодавчому порядку, тобто більш чи менш узагальнені показники проходять голосування представницьким органом і оформляються у статті нормативного акта з вищою юридичною силою» [3, с. 13]. Подібне правове значення бюджету має передбачати те, що бюджет - це план доходів та видатків територіального утворення [4, с. 14].

Для зручності дослідження питання місцевих бюджетів як складової частини місцевих фрінансів в науковій літературі виділяють такі етапи становлення бюджетної системи України та місцевих бюджетів зокрема [2]. Перший етап бюджетної історії України стосується Київської Русі (IX-XII ст.), де головним джерелом поповнення державної казни була данина 3 підкорених народів, яку вони платили здебільшого хутром. Однак починаючи з XI ст. все значущу роль починають відігравати внутрішні джерела, таким чином частку доходів київська казна отримувала від князівств, які входили до складу Київської держави. Основою внутрішніх надходжень були різні види мита та збори, які мали характер податків. Різні види мита можна поділити на два види: заставне (збиралося на початку торгівлі та проїзд) і торговельне. Податкові платежі надходили в різних формах: данина, подать, поклони, корми, побори. 
Наступний історичний період становлення бюджетної системи (XIVXVI ст.) характеризувався розрухою, культурним і духовним занепадом, порушенням політико-династичних зв'язків з іншими регіонами, що пояснюється наслідками монголо-татарської навали. Після занепаду Києва економічне і культурне життя України переміщується до Галицько-Волинського князівства, але з утратою ним могутності відбуваються зміни в економічному і політичному житті українських земель. Україна опинилася під впливом Литви, Польщі та Росії, які, починаючи з XIV ст., стали значно укріплювати свої позиції. Основу економіки України даного періоду становили скотарство, землеробство, різні промисли і торгівля. Досить розвиненими галузями були скотарство і промисли - соляний, деревообробний, мисливство, рибальство, бортництво [5]. На даному етапі рівнів зборів податків було кілька: загальнодержавний, окремого князівства, повіту, села, окремого пана і осадчого. Таким чином, платниками державі були міста, села та окремі власники майна [2].

Наступний етап розвитку бюджетних відносин на території сучасної України характеризується становленням українського козацтва (XV-XVIII ст.). Економіка Січі складалась із двох секторів: січового та індивідуального. Січове господарство поділялось на загальносічове та курінне. Курінь як самостійна господарська одиниця мав майно і доходи, якими Кіш не розпоряджався. Основними видами діяльності козаків було скотарство, рибальство, розведення домашніх тварин, землеробство, добування та доставляння солі, а також хліборобство. Значну частину доходів Січ отримувала від зовнішніх надходжень, а саме військова здобич, царська платня. Однак військова добич не була основним джерелом надходжень, основну їх частину приносила торгівля - від продажу товарів за межами Січі, сплата податків від продажу товарів на території Січі (податки стягувалися через ціни на товари), мито за транзит товарів. Запорізька Січ мала завершену систему збирання та витрачання коштів, бюджет Січі був беззбитковим, збалансування якого досягалось трудовими повинностями, зменшенням платні, регулюванням експортно-торговельних операцій, покриванням частини державних потреб за рахунок старшин.

Наступний етап (XVIII-XIX ст.) характеризується перебуванням України під владою Російської імперії та Австро-Угорщини, це зумовило той фракт, що економіка українських земель зде- більшого слугувала інтересам інших держав. Цей період характеризується зародженням і розвитком наукового обґрунтування необхідності існування місцевих фрінансів і місцевих бюджетів. Важливим кроком до формування бюджетної системи в Росії стала робота М. Сперанського «План фінансів» (1810р.), де йшлося про необхідність оптимального співвідношення видатків і доходів. У 1862 р. відбулася бюджетна реформа, в ході якої була запроваджена єдина система бюджетного обігу та звітності та проголошено принцип гласності бюджету. У ході становлення та розвитку державного бюджету стали зароджуватися і місцеві (регіональні) бюджети, адже на доцільність розмежування державних і місцевих фрінансів у 1776 р. звертає значну увагу А. Сміт у роботі «Дослідження про пригоду та причини багатства народів». Складність наступного періоду (1905-1922 рр.) зумовлена частою зміною політичної ситуацію і громадянською війною [2]. У даний період бюджетних процесів практично не було, але були спроби забезпечити системність державних надходжень і видатків. Перший крок до самостійності бюджетних відносин зробила Центральна Рада, відокремившись від фінансової системи Росії і намагаючись забезпечити власний грошовий обіг. Але практичних дій для реалізації цього положення Центральна Рада не здійснила, таким чином Україна продовжувала залежати від поставок російських грошових знаків. Із приходом до влади гетьмана П. Скоропадського окремі економічні питання вдалося вирішити, завдяки чому почала відновлюватися розбалансована фрінансова система - вдалося створити державний бюджет. Однак Перша світова війна значно підірвала економіку України. Суттєвого поліпшення вдалося досягти лише при зміні економічного курсу - з воєнного комунізму на нову економічну політику (HEП) [2].

За часів існування України у складі СРСР можна виокремити такі періоди у становленні бюджетної системи: 1) 1917-1930рр. - становлення радянської правової системи, прийняття Тимчасового положення про місцеві фрінанси, колективізація, перехід до субвеційної системи, прийняття конституцій радянських республік; 2) 1930-1938 рр. - індустріалізація, податкова реформа, звуження фінансових повноважень місцевих органів влади, організаційне оформлення сільських бюджетів, затвердження бюджетів «згори до низу»; 3) 1938-1945 рр. запровадження єдиного державного бюджету, до якого включалися місцеві бюджети, Друга 
світова війна, Велика вітчизняна війна, вимушене скорочення кількості місцевих бюджетів та їхніх доходів; 4) 1945-1960 рр. - відбудова країни, зміни в обсягах місцевих бюджетів, прийняття закону про бюджетні права СРСР і союзних республік; 5) 1960-1985 рр. - прийняття закону про бюджетні права УРСР, реформа цін, підвищення неоподаткованого мінімуму зарплати, скасування деяких неприбуткових податків, реформування самооподаткування сільського населення, початок перебудови; 6) період 1985-1990 рр. - розгорнута перебудова, прийняття Європейської хартії про місцеве самоврядування, розпад СРСР та утворення незалежної України, початок формування внутрішнього (національного) права [6]. Правові засади бюджетної системи сучасної України становлять: Конституція України, виданий на ії основі Закон України «Про бюджетну систему України», а також Закон України «Про місцеве самоврядування в Україні» від 21 травня 1997 р., Бюджетний Кодекс України від 08 липня 2010 р. Крім цього, 1 квітня 2014 року було схвалено Концепцію реформування місцевого самоврядування та територіальної організації влади в Україні, яку розроблено з урахуванням вимог Європейської хартії.

В Україні вже понад п'ять років триває процес децентралізації державного управління, який передбачає послідовне і глибоке реформування системи публічної влади з урахуванням позитивного досвіду розвинутих демократичних країн і вимог Європейського Союзу. Головна мета реформи децентралізації полягає в передачі значної частини повноважень та бюджетів від державних органів органам місцевого самоврядування [7], а також передбачає три рівні: фрінансова децентралізація, об'єднання громад і ухвалення необхідних змін до чинного законодавства.

Верховна Рада України ухвалила постанову № 3650 «Про утворення та ліквідацію районів», якою реформується субрегіональний рівень адміністративно-територіального устрою України. Цим документом замість наявних в Україні 490 районів створюється 136 укрупнених [8]. Реформа забезпечить відповідність системи адміністративно-територіального устрою районного рівня України сучасним вимогам та європейським стандартам.

Висновки. На підставі вищевикладеного можна зазначити, що розвитку місцевих бюдже- тів України передував складний процес формування фінансової системи України, яка тривалий час була під впливом інших держав. Лише 3 моменту отримання незалежності стало можливим формування власної економічної системи. Однак усі ці процеси відбувались за умов вимушеного прискорення, більшість законодавчих актів були неефективними, суперечливими, фрінансова система наділялася ознаками, притаманними командно-адміністративній економіці, що не найліпшим чином сприяло розвитку місцевих бюджетів. Тому для вирішення різних проблем, що стосуються соціально-економічного розвитку територіальних громад, сьогодні запроваджена та активно втілюється в життя адміністративно-територіальна рефрорма, в контексті якої відбувається децентралізація місцевих бюджетів та реформування законодавства.

Реформа місцевого самоврядування повинна вирішити багато найважливіших проблем, зокрема й щодо наповнення місцевих бюджетів, особливо актуальне це питання в умовах карантину. Однак усе це має здійснюватися в межах цілісного пакету політичних, економічних, соціальних реформ, спрямованих на перетворення України в сучасну європейську країну.

\section{Список використаної літератури:}

1. Конституція України : офріц. текст. Київ : KM, 2013. 96 c.

2. Молодченко Т.Г. Формування бюджетної системи України: історичний аспект. URL : http://www.kbuapa.kharkov.ua/e-book/apdu/2010-2/ doc/2/06.pdf (дата звернення: 05.07.2020).

3. Воронова Л.К. Бюджетноправове регулювання в СРСР. Київ : Вища школа, 1975. 183 с.

4. Чинчин О.В. Фінансово-правове регулювання виконання місцевих бюджетів за доходави в Україні : дис. ... канд. юрид. наук : 12.00.07. Запоріжжя, 2019. 210 с.

5. Пасічник Ю.В. Бюджетна система України та зарубіжних країн: навч. посіб. Київ : Знанняпрес, 2002. $495 \mathrm{c}$.

6. Музика О.А. Доходи місцевих бюджетів за українським законодавством : монографрія. Київ : Атіка, 2004. 344 с.

7. Закіров М. Децентралізація: завдання, перші успіхи і сподівання. Україна: події, факти, коментарі. 2016. № 5. С. 6-11.

8. Постанова про утворення та ліквідацію районів. URL : https://www.rada.gov.ua/news/Novyny/ 196122.html (дата звернення: 21.07.2020). 


\section{Mozolyuk-Bodnar L. M. Historical and legal foundations for the development of local budgets \\ The article considers the historical and legal aspects of the emergence of local budgets} and the stages of formation of the budget system of Ukraine and local budgets in particular. It is noted that the development of local budgets of Ukraine was preceded by a complex process of forming the financial system of Ukraine, which has long been under the influence of other states. It was only from the moment of independence that it became possible to form one's own economic system. However, all these processes took place under conditions of forced acceleration, most legislative acts were ineffective, contradictory, the financial system was endowed with features inherent in the command-administrative economy, which did not best contribute to the development of local budgets. Therefore, in order to solve various problems related to the socio-economic development of territorial communities, an administrative-territorial reform has been introduced and is being actively implemented today, in the context of which local budgets are being decentralized and legislation is being reformed.

It is stated that the main goal of decentralization reform is to transfer a significant part of the powers and budgets from state bodies to local governments, and provides for three levels: financial decentralization, community unification and the adoption of necessary changes to existing legislation.

It is emphasized that the Verkhovna Rada of Ukraine adopted Resolution № 3650 "On the formation and liquidation of districts", which reforms the subregional level of administrative-territorial organization of Ukraine. This document creates 136 enlarged districts instead of the 490 existing ones in Ukraine. The reform will ensure compliance of the system of administrative-territorial organization of the district level of Ukraine with modern requirements and European standards.

The reform of local self-government should solve many important problems, including the filling of local budgets, this issue is especially relevant in quarantine. However, all this must be done within the framework of a holistic package of political, economic and social reforms aimed at transforming Ukraine into a modern European country.

Key words: budget, local budget, decentralization of local budgets, budget system, subregional level of administrative-territorial organization of Ukraine. 


\title{
КОНСТИТУЦІЙНЕ ПРАВО; МУНІЦИПАЛЬНЕ ПРАВО
}

\author{
УДК 342.25 \\ DOI https://doi.org/10.32840/1813-338X-2020.3.3
}

Ю. М. Кириченко

доктор юридичних наук, доцент, професор кафедри правового забезпечення господарської діяльності факультету № 6 Харківського національного університету внутрішніх справ

\section{СТАТУТ ТЕРИТОРІАЛЬНОЇ ГРОМАДИ ЯК ЕФЕКТИВНИЙ ЗАСІБ ЛОКАЛЬНОЇ САМОРЕГУЛЯЦІЇ ТА САМОУПРАВЛІННЯ}

У статті наголошено на тому, що особливе місце в системі нормативних актів місцевого самоврядування посідає статут відповідної територіальної громади, яким регулюється значна кількість процедур безпосередньої демократії, який може ухвалити представницький орган місцевого самоврядування на основі Конституції України та в межах Закону України «Про місцеве самоврядування в Україні» з метою врахування історичних, національно-культурних, соціально-економічних та інших особливостей здійснення місцевого самоврядування.

На підставі вивчення зарубіжного досвіду застосування статутів для врегулювання органами муніципальної влади відносин місцевого значення автором зазначено, що в багатьох містах Європейських країн статути слугують регулюванню управлінських відносин протягом багатьох століть.

Окрему увагу в статmі звернуто на питання щодо визнання статуту територіальної громади нормативно-правовим актом, через ухвалення якого підкреслюється роль територіальних громад у розв'язанні питань місцевого значення.

Автором обгрунтовано думку, що для проведення ефективної реформи децентралізації, яка відбувається сьогодні в Україні, та розвитку демократії на локальному рівні вкрай важливим є ухвалення якісних статутів відповідних територіальних громад. Статут має бути дієвим механізмом здійснення місцевого самоврядування будь-якою територіальною громадою, особливо об'єднаною, що допоможе регламентувати відносини як між окремими громадами, що об'єднались, так і між громадою та органами місцевої державної влади.

Наголошено, що суттево підвищити роль статутів територіальних громад, усунути недоліки чинних статутів і стимулювати процес їх ухвалення всіма територіальними громадами дадуть змогу розроблення та оприлюднення Типових статутів сільських, селищних, міських, а також об'єднаних територіальних громад, які міститимуть ретельно розроблені механізми місцевої демократії, в результаті чого статут стане ефективним засобом саморегуляції та самоуправління відповідної територіальної громади, зокрема й об'єднаної територіальної громади.

Ключові слова: типовий статут, місцеве самоврядування, муніципальна влада, нормативний акт, адміністративний акт.

Постановка проблеми. Органи місцевого самоврядування, здійснюючи владу і самостійно розв'язуючи питання місцевого значення, віднесені законом до їхньої компетенції, та ухвалюючи рішення, які є обов'язковими до виконання на відповідній території, зобов'я- зані діяти лише на підставі, в межах повноважень та у спосіб, що передбачені Конституцією та законами України.

Враховуючи широкий спектр досліджень, присвячених різним аспектам управлінських рішень в адміністративній діяльності владних 
суб'єктів і проблемам, що тісно пов'язані з цим напрямом, необхідно зазначити, що багато питань із цієї сфрери все ще залишаються не досить охопленими, зокрема питання щодо ролі статуту територіальної громади в ефективному розв'язанні органами місцевого самоврядування місцевих проблем. Проте це має не лише теоретичне, а й суттєве практичне значення для становлення, ефективного розвитку та вдосконалення місцевого самоврядування в Україні.

Аналіз останніх досліджень і публікацій. Науково-теоретичне підґрунтя дослідження статуту як однієї з форм нормативних актів органів місцевого самоврядування становлять наукові праці вчених, а саме: В.Б. Авер'янова, О.В. Батанова, М.О. Баймуратова, В.В. Кравченка, О.Є.Кутафіна, В.І. Фадєєватаіншихучених.

Мета статті полягає в тому, щоб на підставі наукових напрацювань визначити сутність і значення статуту як ефективного засобу саморегуляції та самоуправління відповідної територіальної громади.

Виклад основного матеріалу. Закон України «Про місцеве самоврядування в Україні» [1] передбачає такі форми нормативних актів органів місцевого самоврядування: статут територіальної громади села, селища, міста; регламент сільської, селищної, міської ради; рішення сільської, селищної, міської ради; розпорядження сільського, селищного, міського голови; положення (наприклад, про зміст, опис і порядок використання символіки територіальної громади; про постійні комісії місцевої ради та інші); рішення виконавчого комітету сільської, селищної, міської, районної у місті (у разі її створення) ради тощо.

Особливе місце в системі нормативних актів місцевого самоврядування посідає статут відповідної територіальної громади, який, згідно з ч. 1 ст. 19 Закону України «Про місцеве самоврядування в Україні», може ухвалити представницький орган місцевого самоврядування на основі Конституції України та в межах цього Закону з метою врахування історичних, національно-культурних, соціально-економічних та інших особливостей здійснення місцевого самоврядування. Як зазначає М.О. Баймуратов, надання такого права органам місцевого самоврядування $€$ свідченням довіри держави до локальної демократії i, що не менш важливо, завдяки такій локальній нормотворчості з'явилася реальна можливість найбільш повного врахування інтересів територіальних громад [2, с. 100].
Статут територіальної громади підлягає державній реєстрації в центральному органі виконавчої влади, що реалізує державну політику у сорері державної реєстрації (легалізації) об'єднань громадян, інших громадських формувань. Законодавство України не містить вимоги щодо обов'язковості ухвалення статутів, тому сьогодні не всі територіальні громади їх мають.

Зарубіжний досвід свідчить, що в багатьох містах Європейських країн статути слугують регулюванню управлінських відносин протягом багатьох століть. Статутне право бере свій початок із XI-XII ст., зокрема, перший статут Лондона було ухвалено в 1129 році. Ці документи мають усі великі міста Західної Європи та США [3, с. 27].

Більшість дослідників схиляється до позиції, що статут територіальної громади як основний акт локальної саморегуляції, з яким співвідносяться інші акти, рішення і дії місцевого самоврядування, мусить мати найвищу юридичну силу серед актів, які видаються в системі місцевого самоврядування (як безпосередньо населенням, так і особливо органами та посадовими особами місцевого самоврядування) [4, с. 618]. О.В. Батанов зазначає, що статут є основним пріоритетним нормативно-правовим актом територіальної громади, а також своєрідною комунальною конституцією на території функціонування відповідної громади [5, с. 38].

Певною мірою статут $\epsilon$ «угодою між територіальною громадою і владою. Адже він має закріплювати правила взаємодії громадян із державними органами, права й обов'язки громади та її органів, містити систематизований перелік принципів, норм і правил, що встановлюють порядок і процедуру здійснення місцевого самоврядування, тобто бути насамперед процедурним документом, який визначає порядок здійснення норм Конституції та законодавства України в конкретному населеному пункті» [3, с. 28].

Вивчаючи правову природу статуту територіальної громади, варто звернути увагу, що досить часто в науковому просторі виникає питання щодо визнання статуту територіальної громади нормативно-правовим актом. Дискусії з цього приводу виникають через необов'язковість (фракультативність) ухвалення цього документа. Досить переконливо аргументують свою позицію щодо віднесення статутів територіальних громад до нормативно-правових актів місцевого самоврядування В. Куйбіда, С. Злобін та А. Гель. Зокрема, статут ухвалює територіальна громада, яка $€$ уповноваженим 
Конституцією України суб'єктом; його ухвалено у визначеній формі - формі рішення про ухвалення або про підтвердження офріційного письмового документа - і за жорсткою процедурою, як правило, процедурою референдуму. Статут містить загальні правила поведінки не тільки членів територіальної громади, але й органів, які вона утворює, та обраних посадових осіб. Ці правила поведінки розраховані на невизначене коло фрізичних і юридичних осіб, які існують на території дії територіальної громади, оскільки кількість жителів може щоденно змінюватися, можуть утворюватися і ліквідовуватися юридичні особи, але на них усіх поширюватиметься дія статуту. Крім того, статут ухвалюється для неодноразового застосування. Як правило, статут діє невизначений термін (тобто до його зміни або застосування) [6, с. 71-74]. Статут - це не тільки нормативно-правовий акт, це політичний документ, адже на нього покладається завдання об'єднати територіальну громаду в єдине ціле та спрямувати її на захист власних конституційних прав. Через акт ухвалення статуту підкреслюється роль територіальних громад у розв'язанні питань місцевого значення [7, с. 191].

Аналіз чинного законодавства України дає можливість визначити, які питання можуть регулюватися статутами територіальних громад. Наприклад, згідно зч. 3 ст. 8 Закону України «Про місцеве самоврядування в Україні» статутом територіальної громади визначається порядок проведення загальних зборів громадян за місцем проживання; згідно з ч. 2 ст. 9 Закону України «Про місцеве самоврядування в Україні» закріплено, що статутом визначається порядок внесення місцевої ініціативи на розгляд ради; відповідно до ч. 4 ст. 10 Закону України «Про місцеве самоврядування в Україні» статутами територіальних громад визначаються порядок формування та організація діяльності місцевих рад; ч. 4 ст. 13 Закону України «Про місцеве самоврядування в Україні» зазначає, що порядок організації громадських слухань визначається статутом територіальної громади тощо [1].

Як зазначають О.О. Кутафрін і В.І. Фадєєв, «статут муніципального утворення $€$ необхідним елементом правової основи місцевого самоврядування, в якому на основі законодавства про місцеве самоврядування визначаються організація та форми здійснення місцевого самоврядування в цих муніципальних утвореннях, їхні територіальна, фінансово-економічна основи, а також містяться інші положення про органі- зацію місцевого самоврядування, компетенцію та порядок діяльності органів і посадових осіб місцевого самоврядування» [8, с. 217].

Висновки і пропозиції. Як бачимо, достатня кількість процедур безпосередньої демократії може регулюватися саме статутами територіальних громад. Отже, для проведення ефективної реформи децентралізації, яка відбувається сьогодні в нашій державі, та розвитку демократії на локальному рівні, вкрай важливим $€$ ухвалення якісних статутів відповідних територіальних громад. Статут має стати ефективним засобом саморегуляції та самоуправління територіальної громади, зокрема й об'єднаної територіальної громади. В останньому випадку статут допоможе регламентувати відносини як між окремими громадами, що об'єднались, так і між громадою та органами місцевої державної влади. Зокрема, статутом об'єднаної територіальної громади обов'язково мають бути внормовані чіткі механізми взаємодії між громадами, їхні права та обов'язки; враховуватись історичні, національно-культурні, соціально-економічні особливості громад; закріплено порядок розподілення бюджетних коштів між окремими громадами, що об'єднались; порядок узгодження владою об'єднаної територіальної громади з окремою громадою рішення із землевідведення, побудови виробництв, розташування та діяльності об'єктів соціальної інфраструктури тощо. Оскільки Закон України «Про добровільне об'єднання територіальних громад» не досить чітко визначає правовий статус старости як головного представника інтересів об'єднаної територіальної громади, зокрема його права та обов'язки, механізм його відкликання, порядок проведення консультацій старост із громадами, вбачається за доцільне внормувати ці питання статутом. Адже закріплення в статуті правил взаємодії громад і механізмів громадської участі у розв'язанні питань місцевого значення дасть змогу мінімізувати ризики виникнення конфрліктів і протестів як між сусідніми громадами, що об'єднались, так і між владою і членами окремої територіальної громади.

Оцінюючи роль статутів територіальних громад як своєрідних хартій самоврядування, варто зазначити, що вони дають місцевим співдружностям можливість самостійно обрати структуру свого управління, забезпечуючи своєрідний плюралізм форм місцевої демократії $[9$, c. 44]. Проте, аналізуючи норми чинних статутів територіальних громад деяких міст, зокрема Києва, Львова, Одеси, Рівного, Харкова тощо, 
щодо регулювання ними порядку використання таких форм місцевої демократії, як загальні збори, громадські слухання, місцеві ініціативи, консультації з громадськістю, можна виявити як типові, так й індивідуальні недоліки. Зокрема, в більшості статутів процедури організації загальних зборів, внесення членами відповідної територіальної громади місцевої ініціативи, ініціації проведення громадських слухань визначено нечітко та потребують більшої деталізації, зокрема, в частині порядку реалізації пропозицій, висунутих учасниками загальних зборів та громадських слухань. Досить ускладненими виявляються закріплені процедури внесення місцевої ініціативи членами територіальних громад (наприклад, для внесення ініціативи на розгляд Одеської міської ради ініціативній групі необхідно зібрати 5000 підписів, Львівської 750, Рівненської - 1 000, Харківської - 10 000), ініціації громадських слухань членами територіальних громад (зокрема, ініціювати громадські слухання може ініціативна група у складі 20 осіб у місті Харкові та 1000 осіб - у Рівному). Крім того, в деяких статутах територіальних громад члени територіальної громади взагалі не внесено в перелік суб'єктів ініціативи проведення громадських слухань і загальних зборів (наприклад, статути територіальних громад міст Рівного та Миколаєва позбавили такого права членів територіальної громади щодо проведення загальних зборів).

Отже, суттєво підвищити роль статутів територіальних громад, усунути недоліки чинних статутів і стимулювати процес ухвалення статутів усіма територіальними громадами дадуть змогу розроблення та оприлюднення Типових статутів сільських, селищних, міських, а також об'єднаних територіальних громад, які міститимуть ретельно розроблені механізми місцевої демократії.

\section{Список використаної літератури:}

1. Про місцеве самоврядування в Україні : Закон України від 21 травня 1997 р. № 280/97-ВР. База даних «Законодавство України». Верховна Рада України. URL: http://zakon2.rada.gov.ua/ laws/show/280/97-\%D0\%B2\%D1\%80.

2. Баймуратов М.A. Конституционно-проектная регламентация местного самоуправления и территориальных коллективов. Юридический вестник. 1996. № 1.

3. Данількевич М.І., Величко Ю.В. Статут територіальної громади міста - нове явище у праві України. Право України. 2002. № 4. С. 27-29.

4. Актуальні проблеми становлення та розвитку місцевого самоврядування в Україні : монографія / за ред. В.В. Кравченка, М.О. Баймуратова, О.В. Батанова. Київ : Атіка, 2007. 864 с.

5. Батанов О.В. Питання розробки та прийняття статуту територіальної громади. Юридичний журнал. 2004. № 3.

6. Злобін С., Гель А. Місце Статуту територіальної громади в системі нормативно-правових актів України. Cmamym територіальної громади. Проблеми розробки, прийняття та впровадження в практику місцевого самоврядування : навч. посіб. Київ, 1999.

7. Куйбіда В.С. Конституційно-правові проблеми міського самоврядування в Україні. Львів : Літопис, 2001. 375 с.

8. Кутафин О.Е., Фадеев В.И. Муниципальное право Российской Федерации : учебник. 2-е изд., перераб. и доп. Москва : Юристъ, 2000.

9. Черкасов А.И. Сравнительное местное управление: теория и практика. Москва : Издательская группа «ФОРУМ-ИНФРА-М», 1998.

\section{Kyrychenko Yu. M. Statute of the territorial community as an effective means of local self- regulation and self-government}

The article emphasizes that a special place in the system of normative acts of local self-government is occupied by the statute (charter) of the respective territorial community, which regulates a significant number of direct democracy procedures, which can be adopted by a representative body of local self-government on the basis of the Constitution of Ukraine and within the Law of Ukraine "About Local Self-government in Ukraine" in order to take into account historical, national-cultural, socioeconomic and other features of local self-government.

Based on a study of foreign experience in the application of statutes to regulate municipal relations of local importance, the author noted that in many cities of European countries, the statutes serve to regulate administrative relations for many centuries.

Particular attention in the article is paid to the issue of recognition of the statute of the territorial community by a legal act, the adoption of which emphasizes the role of territorial communities in addressing issues of local importance.

The author substantiates the opinion that in order to carry out the effective reform of decentralization that is taking place in Ukraine today and the development of democracy at the local level, it is extremely important to adopt quality statutes of the relevant territorial communities. The charter 
should be an effective mechanism for the exercise of local self-government by any territorial community, especially a united one, which will help regulate relations both between the individual united communities and between the community and local authorities.

It is emphasized that significantly develop the role of statutes of territorial communities, eliminate the shortcomings of existing statutes and stimulate the process of their adoption by all territorial communities as a result, the charter will become an effective means of self-regulation and selfgovernment of the relevant territorial community, in particular, the united territorial community.

Key words: standard statute (charter, regulations, rule), local self-government, municipal authority, normative act, administrative act. 


\section{УДК 342.7}

DOI https://doi.org/10.32840/1813-338X-2020.3.4

\section{А. Ю. Олійник}

кандидат юридичних наук, професор, професор кафедри приватного та публічного права факультету підприємництва та права Київського національного університету технологій та дизайну

\section{РЕАЛІЗАЦІЯ КОНСТИТУЦІЙНОЇ СВОБОДИ ОСОБИ НА ПІДПРИЄМНИЦЬКУ ДІЯЛЬНІСТЬ У ПРОЦЕСІ ВИКОНАННЯ РОБІТ}

У статті розглянуто поняття реалізації конституційної свободи особи на підприємницьку діяльність у процесі виконання робіт. Під час дослідження були вирішені такі завдання : a) проаналізовано авторські праці з питань реалізації конституційних свобод особи на підприємницьку діяльність під час виконання робіт; б) охарактеризовано ознаки реалізації конституційної свободи особи на підприємницьку діяльність у процесі виконання робіт із транспортних перевезень і капітального будівництва; в) запропоновано висновки і рекомендації та пропозиції подальшого дослідження.

Розглянуто ознаки реалізації конституційної свободи особи на підприємницьку діяльність під час виконання робіт транспортних перевезень та капітального будівництва, а саме : а) матеріальні та духовні блага у сфрері виконання робіт; б) втілення конституційних норм у реальні суспільні відносини в названій сфрері; в) названі норми регулюють свободи особи на підприємницьку діяльність під час виконання названих робіт; г) метою діяльності є отримання прибутку чи соціального результату. Реалізації конституційної свободи особи на підприємницьку діяльність у процесі виконання робіт - це втілення конституційних норм у реальні суспільні відносини, що регулюють свободу суб'єктів підприємницької діяльності під час виконання робіт транспортних перевезень та капітального будівництва з метою отримання прибутку чи соціального результату. Виділяють просту і складну фрормами реалізації норм права. Способами безпосередньої реалізації норм права визначають додержання, виконання і використання. Способом опосередкованої форми реалізації права є правозастосування. Норми, що регулюють названі свободи, містяться в: 1) Конституції України 1996 р.; 2) законах України: а) ЦК України; б) ГК України; в) «Про державну реєстрацію юридичних осіб, фрізичних осіб-підприємців та громадських формувань» та ін.

Подальще вивчення теми передбачає дослідження реалізації конституційної свободи особи на підприємницьку діяльність у процесі надання послуг, товарно-грошових, торговельно-обмінних та фрінансових операцій тощо.

Ключові слова: свобода підприємницької діяльності, виконання робіт, фрорми реалізації норм, проста і складна фоорми реалізації свобод, способи реалізації свобод.

Постановка проблеми. Проблема реалізації конституційних свобод особи на підприємницьку діяльність щодо різних ії видів в Україні має теоретичне і практичне значення. Теоретичне значення названої проблеми полягає в тому, що в науці конституційного і господарського права не достатньо повно досліджені основні і особлива форми їі реалізації. Практичне значення проблеми характеризується особливостями здійснення такої свободи під час: 1) виробництва товарів, виконання робіт, надання послуг; 2) товарно-грошових, торговельно-обмінних та фінансових операцій;
3) посередницької діяльності; 4) зовнішньоекономічної діяльності тощо.

Аналіз останніх досліджень та публікацій. Проблема досліджувалася економістами і юристами. Серед авторів-правників, які досліджували проблеми реалізації конституційної свободи особи на підприємницьку діяльність щодо різних ії̈ видів, можна назвати праці таких, як: М.Т. Гаврильців, В.М. Гайворонський, В.П. Жушман, П.О. Зеленський, Б.С. Кінаш, А.Ю. Олійник, В.Ф. Погорілко, О.Ф. Скакун, О.В. Совгиря, В.Л. Федоренко, Н.Г. Шукліна та ін. Питання реалізації конституційної сво- 
боди особи на підприємницьку діяльність у процесі виконання робіт досліджено не достатньо.

Метою дослідження $\epsilon$ особливості здійснення конституційної свободи особи на підприємницьку діяльність під час виконання робіт. Відповідно до мети задачами дослідження є: а) аналіз авторських праць із питань реалізації конституційних свобод особи на підприємницьку діяльність; б) характеристика ознак реалізації конституційної свободи особи на підприємницьку діяльність у процесі виконання робіт та фрормулювання ії визначення; в) висновки і рекомендації та пропозиції щодо подальшого дослідження теми.

Виклад основного матеріалу. А.Ю. Олійник, досліджуючи поняття реалізації конституційної свободи особи на підприємницьку діяльність в Україні, пропонує такі її ознаки, як: а) конституційне закріплення та законодавча деталізація можливості певної поведінки особи у сфрері реалізації благ із метою одержання прибутку; б) матеріальні та духовні блага у сфері виробництва продукції, виконання робіт, надання послуг і торгівлі; в) вільний доступ особи до відповідних благ, їхній обмін, розподіл, володіння, користування, розпорядження, одержання прибутку; г) фрорма поведінки, виявлення волі, інтересів, можливостей особи у названій сфрері; r) втілення конституційної свободи на підприємницьку діяльність у правомірній поведінці особи, держави та суб'єктів громадянського суспільства; д) формування зобов'язань держави у сфрері економічних прав і свобод, включаючи і свободу на підприємницьку діяльність особи [1, с. 98]. Реалізація конституційної свободи особи на підприємницьку діяльність в Україні регулюється нормами Конституції України, які деталізуються правовими нормами законів шляхом нормотворчої діяльності суб'єктів правотворчої діяльності. О.Ф. Скакун розглядає реалізацію норм законів, що деталізують норми конституції. Реалізація названих правових норм характеризується формами і способами їх впливу на поведінку суб'єктів права. Вона виділяє просту (безпосередню) і складну (опосередковану) форми реалізації норм права. За способами безпосередньої реалізації норм права О.Ф. Скакун визначає додержання, виконання і використання. Способом опосередкованої форми реалізації права, на ії думку, є правозастосування [2, с. 418]. Б.C. Кінаш на основі аналізу різних наукових підходів зарубіжних і вітчизняних дослідників виокремлює чотири головні теоретичні моделі форм реалізації конституційно-правових норм: дотримання, виконання, використання і застосування. Дотримання, на думку Б.С. Кінаша, $\epsilon$ формю реалізації забороняючих дію конституційно-правових норм, які регламентують юридичні обов'язки суб'єктів конституційних правовідносин тільки пасивного характеру, мета досягається не через вчинення активних дій суб'єктів конституційних правовідносин, а завдяки утриманню від дій забороненими нормами, суворому дотриманню встановлених заборон, що зумовлює їх пасивну правову поведінку. У сорері дотримання, як форми реалізації конституційно-правових норм, реалізуються не тільки заборонні норми, а й норми охоронного характеру, які за своїм юридичним змістом накладають вето на певні дії шляхом установлення щодо них юридичної відповідальності, чим стимулюють правову пасивну поведінку, яка $€$ основною ознакою зазначеної форми реалізації [3]. Виконання - це здійснення суб'єктом конституційних правовідносин юридично-правових активних дій, передбачених диспозицією конституційно-правової норми, що мають позитивний зміст і обов'язковий характер. Виконання, як форма реалізації конституційно-правових норм, завжди припускає більш високий рівень активності суб'єктів права і спрямовує їх на виконання конституційних установлень позитивного характеру. Юридичний зміст виконання полягає в обов'язковому здійсненні передбачених конституційними нормами дій, у виконанні державно-владних імперативних вимог незалежно від особистого ставлення до них суб'єктів конституційних правовідносин. Виконання, як правило, вимагає юридичного (документального) оформлення [3]. Використання конституційно-правових норм - це форма реалізації уповноважуючих конституційно-правових норм, які наділяють суб'єктів конституційних правовідносин певними суб'єктивними правами і свободами та у своїй диспозиції містять слова «має право», «може». Суб'єктивні права і свободи, які підлягають реалізації у формі використання, надаються особі у вигляді дозволу [3]. Застосування конституційно-правових норм - це правова форма діяльності з реалізації конституційно-правових норм за визначеною процедурою владно-компетентних суб'єктів, яка спрямована на вирішення юридичних справ, що виникають і розглядаються у сфері їх відання, унаслідок якої виноситься відповідний правозастосовний акт (акт застосування конституційно-правових норм) [3]. М.Т. Гаврильців, досліджуючи ефек- 
тивність реалізації Конституції України, наголошує на тому, що процес ії реалізації безпосередньо пов'язаний 3 утвердженням і підтриманням конституційного правопорядку. Необхідність його закріплення не лише випливає з регламентації та виконання конституційних приписів і норм, але й відображається в тому, якою мірою учасники суспільних відносин можуть здійснювати належні їм суб'єктивні права та свободи [4, с. 25]. У суспільстві важливість механізму реалізації Конституції України доводиться тим, що завдяки йому утверджується конституційний правопорядок, що ґрунтується на обмеженні публічної влади законом та гарантуванні основних прав, свобод і законних інтересів людини та громадянина. 3 огляду на це до ключових елементів механізму реалізації Конституції України він відносить правові заходи, спрямовані на: а) утвердження конституційної законності та правопорядку; б) конкретизацію й деталізацію конституційних законів та їх окремих норм, що отримують розвиток у конституційному законодавстві; в) інтерпретацію конституційних норм уповноваженим суб'єктом; г) належний правовий захист основоположних конституційних принципів і цінностей $[4$, с. 28$]$. П.О. Зеленський до економічних свобод особи відносить свободу приватної власності та підприємницької діяльності. На його думку, економічні свободи відображають економічну складову частину природних прав і свобод людини, забезпечують, господарську автономність індивідів, їх взаємозв'язок один з однимісуспільствомуцілому [5, с. 121]. В.Ф.Погорілко, В.Л. Федоренко конституційну свободу особи на підприємницьку діяльність розглядають як не заборонену законами можливість людини і громадянина здійснювати на свій ризик діяльність, що передбачає отримання прибутку. За суб'єктивною ознакою конституційна свобода на підприємницьку діяльність реалізується громадянами України, іноземцями і особами без громадянства в межах чинних законів. Конституційна свобода на підприємницьку діяльність обмежується для депутатів, посадових і службових осіб органів державної влади і органів місцевого самоврядування, військовослужбовців, співробітників правоохоронних органів, суддів та деяких інших категорій людей. Законами можуть обмежуватися або заборонятися окремі види підприємницької діяльності. На державу та ії органи і посадових осіб покладаються обов'язки створювати сприятливі умови для реалізації конституційної сво- боди на підприємницьку діяльність, охороняти підприємців та учасників господарювання від правопорушень, припиняти правопорушення і притягати до юридичної відповідальності та поновлювати порушену конституційну свободу, слідкувати за якістю і безпечністю продукції, усіх видів робіт та послуг, сприяти діяльності громадських організацій споживачів, сприяти забезпеченню соціального характеру підприємницької діяльності в Україні [6, с. 224-226]. О.В. Совгиря, Н.Г. Шукліна реалізацію конституційної свободи особи на підприємницьку діяльність розглядають у системі економічних прав та свобод людини і громадянина і розуміють їх можливості володіти, користуватися та розпоряджатися економічними благами, набувати, реалізувати і захищати їх у порядку, межах, формах і способах передбачених Конституцією та законами України. Вони розділяють думку російських вчених Б.О. Страшуна і В.В. Маклакова щодо утворення дійсно правового фундаменту свободи людини саме конституційними правами на приватну власність і підприємницьку діяльність [7, с. 176]. В.М. Гайворонський пише, що в науковий обіг поняття «підприємець», «підприємництво» В літературі введено з посиланням на те, що розходження між попитом і пропонуванням на ринку дають можливість окремим індивідам купувати чужі товари за певними цінами, а свої продавати за більш високими, але їм поки що не відомими. Такі суб'єкти, діючи в умовах ризику, і $є$ підприємцями. Він підкреслює, що довгий час економісти негативно оцінювали творчого підприємця. Загальний прорив позитивної історії підприємництва відбувся лише в 1912 році, коли вийшла у світ книжка Й. Шумпетера «Теорія економічного розвитку». Він розробив тип творчого підприємця, який реалізує нововведення і в такий спосіб забезпечує економічне зростання. На думку В.М. Гайворонського, підприємець-інноватор визнається однією з центральних фрігур господарської діяльності. Інновація, за Шумпетером, - це не тільки виготовлення нового продукту та впровадження нових технологій, а й освоєння нових ринків збуту, нових джерел сировини, нових фрорм індустріальної організації [8, с. 54]. Суб'єктом господарювання визнаються учасники господарських відносин, які здійснюють господарську діяльність, реалізуючи господарську компетенцію, мають відокремлене майно, несуть відповідальність за своїми зобов'язаннями в межах цього майна, крім випадків, передбачених зако- 
нодавством. До них відносяться громадяни України, іноземці та особи без громадянства, які здійснюють господарську діяльність та зареєстровані відповідно до закону як підприємці (ст. 55) [8, с. 61]. Основним засобом організації відносин між суб'єктами господарювання (включаючи підприємців) в умовах становлення соціально орієнтованої ринкової економіки $є$ господарський договір. Саме господарський договір $\epsilon$ гнучким регулятором підприємницької діяльності і інструментом її планування, формою і засобом організації господарських зв'язків. На думку В.П. Жушмана, господарський договір $\epsilon$ формою вираження господарського зобов'язання. Господарському договору притаманні особливий суб'єктний склад, специфіка діяльності суб'єктів господарювання, мета, для досягнення якої укладається цей договір [8, с. 170]. Так, господарські договори укладаються під час виконання таких робіт, як транспортні перевезення та капітальне будівництво. Р.П. Бойчук підкреслює, що за договором перевезення вантажу одна сторона (перевізник) зобов'язується доставити ввірений їй другою стороною (вантажовідправником) вантаж до пункту призначення в установлений законодавством чи договором строк і видати його уповноваженій на одержання вантажу особі (вантажоодержувачу), а вантажовідправник зобов'язується сплатити за перевезення вантажу встановлену плату [8, с. 294]. Будівництво здійснюється відповідно до закону на підставі договору підряду. За договором підряду одна сторона (підрядник) зобов'язується на свій ризик виконати певну роботу за завданням другої сторони (замовника), а замовник зобов'язується прийняти та оплатити виконану роботу. Договір підряду може укладатися на виготовлення, обробку, переробку, ремонт речі або на виконання іншої роботи з переданням її результату замовникові (ст. 837 ЦК України) [9]. За договором підряду на капітальне будівництво одна сторона (підрядник) зобов'язується своїми силами і засобами на замовлення другої сторони (замовника) побудувати і здати замовникові у встановлений строк визначений договором об'єкт відповідно до проектно-кошторисної документації або виконати зумовлені договором будівельні та інші роботи, а замовник зобов'язується передати підряднику затверджену проектно-кошторисну документацію, надати йому будівельний майданчик, прийняти закінчені будівництвом об'єкти і оплатити їх (ст. 318) [10]. Питання реалізації конституційної свободи особи на підприємницьку діяльність у процесі виконання певних робіт має певні обмеження і заборони. Г.В. Ільющенко, досліджуючи деякі аспекти обмежень права на підприємницьку діяльність, підкреслює, що умовами здійснення підприємницької діяльності $€$ повна цивільна дієздатність фізичної особи та державна реєстрація. Обмеження правоздатності можливе лише у випадках і в порядку, визначених законом. За законодавством України фізична особа може бути частково обмежена у правоздатності, але не позбавлена правоздатності в цілому (ст. 50 ЦК України) [11, с. 111].

Отже, поведений аналіз наукових і нормативних джерел дає можливість сфрормулювати ознаки реалізації конституційної свободи особи на підприємницьку діяльність у процесі виконання робіт. Так, до них відносяться: а) матеріальні та духовні блага у сорері виконання робіт транспортних перевезень та капітального будівництва; б) втілення конституційних норм у реальні суспільні відносини в названій сорері; в) названі норми регулюють свободи особи на підприємницьку діяльність під час виконання робіт; г) метою діяльності є отримання прибутку чи соціального результату.

Ознакою реалізації конституційної свободи особи на підприємницьку діяльність у процесі виконання робіт є матеріальні та духовні блага у сорері виконання робіт (наприклад, транспортних перевезень та капітального будівництва). Транспортні перевезення, як виконання робіт, можуть здійснюватися на сухопутному, водному і повітряному транспорті. До сухопутного транспорту слід віднести автомобільний і залізничний транспорт. Водний транспорт може бути морським і річковим. Повітряним транспортом є літаки. Транспортні перевезення можуть здійснюватися щодо пасажирів і речей. Під час здійснення перевезень можуть укладатися договори перевезення. Проводяться внутрішні територіальні і міжнародні перевезення. Капітальне будівництво слід розглядати як підприємницьку діяльність фрізичної особи, спрямовану на створення нових та модернізацію наявних основних фондів виробничого і невиробничого призначення.

Реалізація конституційної свободи на підприємницьку діяльність під час виконання робіт розглядається як втілення конституційних норм у реальні суспільні відносини в названій сорері. Виділяють просту і складну формами реалізації норм права. Способами безпосередньої реалізації норм права визна- 
чають додержання, виконання і використання. Способом опосередкованої форми реалізації права є правозастосування.

Норми Конституції та законів України регулюють свободи особи на підприємницьку діяльність під час виконання робіт та містяться в: 1) Конституції України 1996 р.; 2) законах України: а) ЦК України; б) ГК України; в) «Про державну реєстрацію юридичних осіб, орізичних осіб-підприємців та громадських фрормувань»; г) «Про колективне сільськогосподарське підприємство»; r) «Про ліцензування видів господарської діяльності»; д) «Про акціонерні товариства»; е) «Про товариства з обмеженою та додатковою відповідальністю» та ін.

Метою діяльності щодо реалізації конституційної свободи особи на підприємницьку діяльність у процесі виконання робіт щодо транспортних перевезень та капітального будівництва є отримання прибутку чи соціального результату.

Висновок. Підсумовуючи матеріали дослідження, зробимо деякі висновки і рекомендації. Ознаками реалізації конституційної свободи особи на підприємницьку діяльність при виконанні робіт є: а) матеріальні та духовні блага у сфрері виконання робіт транспортних перевезень та капітального будівництва; б) втілення конституційних норм у реальні суспільні відносини в названій сфрері; в) названі норми регулюють свободи особи на підприємницьку діяльність під час виконання названих робіт; г) метою діяльності є отримання прибутку чи соціального результату.

Реалізація конституційної свободи особи на підприємницьку діяльність у процесі виконання робіт - це втілення конституційних норм у реальні суспільні відносини, що регулюють свободу суб'єктів підприємницької діяльності під час виконання робіт транспортних перевезень та капітального будівництва з метою отримання прибутку чи соціального результату.

Подальше дослідження теми передбачає реалізацію конституційної свободи особи на підприємницьку діяльність у процесі надання послуг, товарно-грошових, торговельно-обмінних та фрінансових операцій тощо.

\section{Список використаної літератури:}

1. Олійник А.Ю. Поняття реалізації конституційної свободи особи на підприємницьку діяльність в Україні. Право і суспільство. 2020. № 2. C. 98-103.

2. Скакун О.Ф. Теорія права і держави : підручник. 3-те видання. Київ : Алерта, 2012. 524 с.

3. Кінаш Б.С. Конституційно-правові норми: теорія та практика реалізації : автореф. дис... канд. наук: 12.00.02. Київ, 2008. 18 с.

4. Гаврильців М.Т. Реалізація Конституції України : ефективність дії та напрями ії забезпеченні в умовах конституційно-правової реформи. Право і суспільство. 2020. № 2. С. 25-31.

5. Общая теория государства и права : учебник / под ред. С.Ю. Наумова, А.С. Мордовца, Т.В. Касаевой. Саратов : Саратовский социально-экономический институт (филиал) РЭУ им. Г.В. Плеханова, 2018. 392 с.

6. Погорілко В.Ф., Федоренко В.Л. Конституційне право України : підручник / За заг. ред. проф. В.Л. Федоренка. 3-вид., перероб. і доопр. ; передмова проф. В.В. Коваленка. Київ : КНТ, Видавництво Ліра-К, 2011. 532 с.

7. Совгиря О.В. Конституційне право України : навч. посібник. Київ : Юрінком Інтер, 2008. 632 с.

8. Господарське право України : підручник для студентів юридичних спеціальностей вищих закладів освіти / В. М. Гайворонський, В. П. Жушман, Н.В. Погорецька та ін. ; за ред. В.М. Гайворонського та В.П. Жушмана. Харків : Право, 2005. 384 с.

9. Цивільний кодекс України : Закон України від 16 січня 2003 року. Відомості Верховної Ради України. 2003. №№ 40-44. Ст. 356. Поточна редакція від 04.07.2020 р.

10.Господарський кодекс України : Закон України від 16 січня 2003 р. Відомості верховної Ради України. 2003. № 18, № 19-20, № 21-22. Ст. 144. Поточна редакція від 04.07.2020 p.

11. Ільющенко Г.В. Деякі аспекти обмежень права на підприємницьку діяльність. Порівняльно-аналітичне право. 2013. № 4. С. 111-114.

Oliynyk A. Yu. Realization of the constitutional freedom of a person for entrepreneurial activity in the process of performance of works

The article considers the concept of realization of the constitutional freedom of a person for entrepreneurial activity in the process of performance of works. The following tasks were solved during the research: a) the author's works on the issues of realization of the constitutional freedoms of a person for entrepreneurial activity in the performance of works were analyzed; $b$ ) the signs of realization of the constitutional freedom of the person on business activity in the course of performance of works on transport transportation and capital construction are characterized; c) the conclusions and recommendations and offers of the further research are offered. 
The signs of realization of the constitutional freedom of a person for entrepreneurial activity in the performance of transport works and capital construction are considered, namely: a) material and spiritual benefits in the field of performance of works; b) the implementation of constitutional norms in real social relations in this area; c) the specified norms regulate freedoms of the person on business activity at performance of the specified works; d) the purpose of the activity is to obtain a profit or social result. The realization of the constitutional freedom of a person to engage in entrepreneurial activity in the course of work is the implementation of constitutional norms in real social relations governing the freedom of business entities in the performance of transport and capital construction for profit or social result. There are simple and complex forms of implementation of the law. Ways of direct implementation of the rules of law determine compliance, implementation and use. The way of indirect form of realization of the right is law enforcement. The norms governing these freedoms are contained in: 1) the Constitution of Ukraine of 1996; 2) laws of Ukraine: a) the Central Committee of Ukraine; b) the Civil Code of Ukraine; c) On state registration of legal entities, natural personsentrepreneurs and public formations, etc.

Further study of the topic involves a study of the implementation of the constitutional freedom of the individual to entrepreneurial activity in the process of providing services, commodity-money, trade-exchange and financial transactions, and so on.

Key words: freedom of entrepreneurial activity, performance of works, forms of realization of norms, simple and complex forms of realization of freedoms, ways of realization of freedoms. 


\title{
ЦИВІЛЬНЕ ПРАВО І ПРОЦЕС
}

УдК 347.4

DOI https://doi.org/10.32840/1813-338X-2020.3.5

\author{
П. Д. Гуйван \\ кандидат юридичних наук, заслужений юрист України, \\ профресор \\ Полтавського інституту бізнесу
}

Міжнародного науково-технічного університету імені академіка Юрія Бугая

\section{ПРАВОВЕ РЕГУЛЮВАННЯ ВІДПОВІДАЛЬНОСТІ ЗА ДИФАМАЦІЮ, ІІІ СПІВВІДНОШЕННЯ ЗІ СВОБОДОЮ СЛОВА}

Наукову статтю присвячено дослідженню актуального питання протидії дифрамації як негативному суспільному френомену та сутнісному відмежуванню схожих протиправних проявів від належного здійснення права особи через засоби масової інформації вільно виказувати свої думки, ідеї та погляди. В роботі обстоюється положення, що саме через масмедіа відбувається публічне освоєння інфформації, $i$, відповідно, здійснюється регулювання правової, соціальної і політичної поведінки, гарантується прийнятність етичних, культурних і моральних традицій. При цьому реалізація повноважень журналістської свободи передбачає можливість висловлювання не лише толерантних і сприятливих для особи думок, а й відомостей, які іноді шокують і викликають стурбованість і занепокоєння. Ба більше, активна публічна дискусія передбачає використання у масмедіа певного перебільшення або навіть провокативності. Такими є задекларовані Конвенцією про захист прав особи й основоположних свобод вимоги терпимості, плюралізму і широти поглядів, без яких демократичне суспільство неможливе. Але користування ЗМІ не повинно супроводжуватися зловживаннями. Це означає, що свобода засобів масової інформації покладає на них певні обов'язки перед суспільством. Вони полягають у потребі подавати достовірну інформацію, перевіряти ії перед поширенням, забезпечувати максимальну повноту відомостей, гарантувати об'єктивне подання повідомлень, оскільки будь-яке перекручення чи спотворення інформації є неприпустимим. У разі невиконання позитивних зобов'язань $i$, як наслідок, порушення прав і свобод, що охороняються державою, настають обмеження права на свободу слова та відповідальність перед законом. Іноді визначити підставність для неї та відділити протиправну діяльність від легітимної - непросто. Необхідно використовувати напрацьовані Європейським судом із прав людини критерії щодо застосування норм щодо протидії дифрамації й одночасно обмежувати право на свободу слова в чітко встановлених випадках. Але обов'язково мусять враховуватися такі основні чинники: обмежувальні норми мають бути встановлені законом, бути передбачуваними, спрямованими на легітимну мету і необхідними в демократичному суспільстві.

Ключові слова: свобода вираження, відповідальність за дифамацію, ЗМІ.

Постановка проблеми. У демократичному суспільстві свобода слова найповніше виражається у свободі преси. Можливість особи вільно поширювати без обмежень із боку влади та інших перешкод свої ідеї, думки, інфрормацію через друковане слово та засоби масової комунікації проголошується у спеціальному Законі України «Про друковані засоби масової інформації (пресу) в Україні» від 16 листопада 1992 р.: кожен може вільно й незалежно шукати, одержувати, фріксувати, зберігати, використовувати та поширювати будь-яку інформацію за допомогою друкованих засобів масової інформації. Відтак засоби масової інфрормації в сучасному суспільстві відіграють ключову, а часом і визначальну, роль у процесі фрормування громадянської позиції, суспільної думки, підвищення правосвідомості й правової культури 
громадян. Саме через масмедіа відбувається публічне освоєння інформації і, відповідно, здійснюється регулювання правової, соціальної і політичної поведінки, гарантується прийнятність етичних, культурних і моральних традицій. Але користування 3MI не має супроводжуватися зловживаннями. У ст. 2 вказаного вище Закону зазначається неприпустимість використання друкованого слова у випадках, визначених законом, коли відповідне обмеження необхідне в інтересах національної безпеки, територіальної цілісності або громадського порядку з метою запобігання заворушенням чи злочинам, для охорони здоров'я населення, для захисту репутації або прав інших людей, для запобігання розголошенню інформації, одержаної конфіденційно, або для підтримання авторитету і неупередженості правосуддя [1]. Утім, свобода висловлення думок $є$ одним із базових елементів побудови демократичного суспільства та його вдосконалення й розвитку, а доцільність її обмеження мусить обов'язково мати чітке законодавче обґрунтування, що мусить застосовуватися на всіх етапах роботи 3 інформацією в публічній сфері [2, с. 36].

Сьогодні питання юридичного закріплення належних правил поведінки журналістів щодо знаходження розумного балансу між необхідністю висвітлення насущних проблем у політиці, економіці та інших сторонах життя й охороною приватних прав особи є досить актуальним. На жаль, воно розв'язується дуже повільно, не напрацьовано чітких критеріїв розмежування вказаних інтересів. Тож маємо часті зловживання свободою масової інформації, які виявляються в порушенні прав людини чи нехтуванні суспільними інтересами, і це стає все більш масовим явищем. Неправомірне поширення правових гарантій «свободи масової інфрормації» фрактично виводить 3МІ зі сорери державно-правового регулювання, зумовлює їхню деструктивну суспільну роль. Негативний вплив здійснюється через суперечливість і недосконалість правового регулювання суспільних відносин в інформаційній сфері [3, с. 12]. Особливої актуальності нині набуває проблема, що стосується дифамації (завдання образи) шляхом поширення завідомо недостовірних відомостей про особу, зневажливих та образливих висловлювань. Відповідно до ст. ст. 94, 277 ЦК фізична чи юридична особа, особисті немайнові права якої порушено внаслідок поширення про неї недостовірної інформації, має право на відповідь, а також на спростування цієї інформації.
Потерпілий суб'єкт має право вимагати відшкодування моральної шкоди, завданої внаслідок такого неправомірного діяння. Зрештою, у нашому правовому полі $є$ санкції адміністративного і кримінального характеру за відповідні протиправні вчинки. Але в правових підходах у цій царині $\epsilon$ серйозна завада: не встановлено критерії, які б дали змогу чітко відмежувати належну організацію здійснення права на свободу слова від незаконних дій, пов'язаних зі зловживанням ним.

Аналіз останніх досліджень і публікацій. Проблема правомірного здійснення прав, що гарантовані свободою слова, доцільності й адекватності їх обмеження та його нормативного оформлення була предметом розгляду в низці наукових публікацій таких авторів, як Г.Ю. Арапова, М.О. Лєдовських, А.В. Тітко, С.І. Вільнянський, Є.В. Гаврилов, П.М. Рабінович, О.Г. Марценюк, О.Л. Невзгодіна, В.С. Цимбалюк та інші. У цих роботах розкрито окремі аспекти порушеного автором питання, зокрема, стосовно дотримання конституційних гарантій самовираження людини, зокрема, через засоби масової інформації. Однак дослідження деструктивного впливу поширення неправдивих відомостей на суспільні відносини практично не проводилося. 3 іншого боку, нез'ясованим залишається питання щодо обґрунтованості та виваженості застосовуваних владними інституціями заходів обмеження права на вільне висловлювання. Видається, що держава вельми довільно визначає підстави для свого втручання, що часто призводить до сваволі. Не напрацьовано єдиного правового підходу до визначення обов'язків відмежування фактичних тверджень від оціночних суджень, встановлення переліку публічних соціально важливих відомостей, які $€$ необхідними для особи та дають можливість належно задовольнити її публічний інтерес.

Метою статті $€$ дослідження теоретичних питань і правозастосовної практики щодо правомірного оприлюднення суспільно важливої інформації та відділення її від дифамації в публічній сфері як негативного феномена.

Виклад основного матеріалу. У ст. 32 Конституції України передбачено судовий захист права спростовувати недостовірну інформацію про себе та членів своєї сім'ї, оскільки ніхто не може зазнавати втручання у своє особисте та сімейне життя, крім випадків, передбачених Конституцією. Не допускається збирання, зберігання, використання та поширення конфіденційної інформації про особу без її згоди, крім 
випадків, визначених законом, і лише в інтересах національної безпеки, економічного добробуту та прав людини. 3 іншого боку, будь-яка особа має право особисто чи через засоби масової інфрормації поширювати відомості про події, явища, зокрема, і про учасників цих процесів. Неодмінно в суспільстві мають виникати колізії між правом соціуму бути поінформованим через масмедіа і можливим порушенням прав окремих суб'єктів на приватність. I такі колізії надзвичайно часто виникають передовсім через невизначеність і неоднозначності позиції державних законодавчих і правозастосовних органів.

3 одного боку, завдяки окремим рішенням судів органи масової інфрормації, які належать владі, виведено з-під дії конституційних правил щодо неприпустимості дифамаційних проявів і відповідальності за них. Зокрема, за постановою Великої Палати Верховного Суду, яка спеціально присвятила цьому питанню своє засідання, якщо завідомо неправдиву інформацію про особу було публічно поширено органом влади під час здійснення повноважень у сфері його компетенції, відповідальність не настає [4]. У такий спосіб український суд, по-перше, усунув владні інституції від відповідальності за поширення через масмедіа неправдивої інформації (хоча матеріальний закон вказує на відповідальність державних органів, практично це здійснити неможливо, бо будь-які дії владних структур здійснюються ними під час виконання повноважень, а в такому разі за рішення ВП ВС дифамація не $є$ караною). А по-друге, віднісши питання про відповідальність за поширення недостовірних відомостей органом влади до юрисдикції адміністративних судів, вищий орган правосуддя забив ще один цвях у домовину належного правопорядку в країні, додавши черговий крок у перетворенні нашої держави в командно-вольове суспільство. Адже розв'язання спорів, що споконвіку перебували у площині горизонтального розв'язання (сторони спору були процесуально рівні), нині відбувається у вертикальному ракурсі. Бо в адміністративних взаєминах завжди $є$ взаємодія на рівні управнений суб'єкт (орган влади) - підпорядкована особа. Втиснувши загалом цивільні відносини в прокрустове ложе адміністративного регулювання, суд потурбувався про чиновників, дозволивши їм безкарно привселюдно ображати особу, поширювати недостовірну інформацію про неї, здійснюючи ці вчинки в межах реалізації своїх повноважень.
3 іншого боку, маємо численні спроби обмежити свободу вираження журналістів і приватних осіб, які висвітлюють події та надають інфрормаційні повідомлення. Як не дивно, але цей перекіс також спрямований на підвищену охорону інтересів саме державних мужів. Зокрема, часто здійснюються намагання встановити підвищений рівень відповідальності за завдання образи високопоставленим офіційним особам (наприклад, президенту, урядовцям, парламентарям) або державним службовцям (наприклад, співробітникам прокуратури та інших правоохоронних органів, а також працівникам державних установ). Утім, встановлення більш суворого покарання за дифрамацію зазначених вище категорій осіб суперечить принципу рівності перед законом. Адже в ч. 2 ст. 10 Європейської конвенції про захист прав людини й основоположних свобод, яка за нашим законодавством $€$ джерелом національного права, серед чеснот, які може бути захищено шляхом обмеження свободи слова, не вказується такої, як державна влада.

Про це чітко зазначає Європейський суд із прав людини. Зокрема, у справі «Торгейрсон проти Ісландії» Суд відхилив запропоновану національною владою певну градацію визначення суспільного значення питань, спираючись на суб'єктний склад учасників відносин. Уряд у цій справі вважав, що широкі межі політичної критики, що зазвичай використовуються в суспільстві й обстоюються Судом, не можуть застосовуватися за публічної оцінки поліції, тому що описані в статті правопорушення з боку поліції не були пов'язані з прямою або непрямою участю громадян у процесі ухвалення рішень у демократичному суспільстві. Не погодившись із таким підходом, Суд зауважив, що в європейській судовій практиці немає жодних гарантій щодо відмінності між політичною дискусією та обговоренням інших питань, які становлять суспільний інтерес. Прагнення обмежити право на свободу вираження поглядів на основі визнання ст. 10 такою, що ії̈ виконання має різне застосування до окремих суб'єктів дискусії, $є$ неправомірним. Обмеження може запроваджуватися лише за умов, передбачених абзацом другим цієї статті. В іншому разі вводиться обмежувальна умова, якої немає в ч. 2 ст. 10 [5, п. 61, 64].

Зрештою, враховуючи, що Україна перебуває на початковому етапі правового опосередкування коментованих відносин і за великим рахунком не поспішає в цьому поступі, 
маємо ретельніше придивитися до усталеної практики міжнародних юридичних інституцій у цій царині й адаптувати їхні напрацювання до наших реалій. За прецедентною позицією ЄСПЛ під час реалізації своїх повноважень журналістська свобода передбачає можливість висловлювання не лише толерантних і сприятливих для особи думок, а й відомостей, які іноді шокують і викликають стурбованість і занепокоєння. Ба більше, активна публічна дискусія передбачає використання у масмедіа певного перебільшення або навіть провокативності [6, п. 38]. Такими є вимоги терпимості, плюралізму й широти поглядів, без яких демократичне суспільство неможливе. Водночас свобода засобів масової інформації покладає на них певні обов'язки перед суспільством. Вони полягають у необхідності подавати достовірну інформацію, перевіряти ії перед поширенням, забезпечувати максимальну повноту відомостей, гарантувати об'єктивне подання повідомлень, оскільки будь-яке перекручення чи спотворення інформації $€$ неприпустимим. За позицією ЄСПЛ, кожна «формальність», «обмеження» або «санкція», що застосовуються до цієї галузі, має бути пропорційною переслідуваній ними законній меті.

3 іншого погляду будь-яка людина під час здійснення своєї свободи вираження поглядів несе «обов'язки і відповідальність», ступінь яких залежить від ситуації й технічних засобів, які вона використовує. Суд не може не звернути увагу на ці «обов'язки і відповідальність», коли з'ясовує, чи сприяли ці обмеження або санкції «охороні моральності», що робило б їх «необхідними в демократичному суспільстві». У разі невиконання позитивних зобов'язань і, як наслідок, порушення прав і свобод, що охороняються державою, настають обмеження права на свободу слова та відповідальність перед законом. Іноді визначити підставність для неї та відділити протиправну діяльність від легітимної непросто. Скажімо, нормам щодо дифамації, які регулюють питання захисту честі та репутації, притаманна певна широта тлумачення національними органами, тобто вони переважно сорормульовані досить загально. Але все ж таки норми мусять мати характер закону у розумінні ст. 10 Конвенції як правила загальноприйнятної поведінки. При цьому основними елементами під час розгляду того, чи $є$ втручання встановлено законом, вважаються передбачуваність норми, її спрямованість на легітимну мету і прийнятність у демократичному суспільстві.
Проілюструємо виважений підхід Європейського суду з прав людини під час практичного розв'язання правової колізії між правом людини на честь та гідність і можливістю вільно публічно висловлювати свої думки на прикладі справи «Нільсен і Йонсен проти Норвегії [7]. Заявники - минулі працівники національної поліції. Пан Нільсен - інспектор поліції, який у час виникнення спору був головою Норвезької асоціації поліції. Два науковці - пан Гуннар Нордхус і доцент соціології пан Едвард Фогт, провели розслідування явища насильства в поліції. Вони зібрали матеріал із місцевої лікарні та інших джерел, що стосуються всіх пацієнтів, які зазнали насильства протягом певного періоду, й опублікували короткий виклад своїх доповідей у книзі під назвою «Насильство та його жертви. Емпіричне дослідження». Книга про жорстокість поліції, незаконне застосування фізичної сили під час виконання своїх обов'язків на 280 сторінках була поширена в місті, де проживає понад 200000 населення. Книга породила бурхливу публічну дискусію, у якій також брали участь і співробітники поліції та прокуратури. Саме твердження цих працівників, які виступають заявниками в цій справі, були визнані судами Норвегії як дифамаційні, бо не виважено та необґрунтовано ображали авторів книги, ганьбили їхню честь і гідність. Зокрема, в оприлюднених повідомленнях заявників автори книги звинувачувалися у неправдивості, свідомій брехні, нечесних мотивах і фабрикуванні звинувачень у жорстокості поліції. Верховний суд Норвегії встановив, що подібні звинувачення авторів книги були наклепницькими, «незаконними» і не виявилися правдою, та підтримав рішення міського суду про відшкодування збитків із боку заявників.

Звертаючись до ЄСПЛ, заявники скаржились на невиправдане втручання у їхнє право на свободу вираження поглядів відповідно до ст. 10 Конвенції. Під час розгляду справи по суті Суд встановив, що вказана реакція органів влади становила собою втручання у право заявників на свободу вираження, гарантовану згідно з абзацом першим ст. 10. Відтак необхідно було визначити, чи було таке втручання виправданим. Спершу Суд постановив, що обмеження, застосовані до заявників, були «передбачені законом» і переслідували законну мету, а саме «захист репутації чи прав інших людей». Тож він зосередився на дослідженні третьої обов'язкової умови: щоб втручання було «необхідним у демократичному суспільстві». Особливістю 
цієї справи $є$ те, що заявників було притягнуто до відповідальності за заяви, які вони висловлювали як представники поліційної асоціації у відповідь на повідомлення, що оприлюднювали звинувачення у справах, пов'язаних із правопорушеннями поліції. Зазвичай Суд захищає права людей, які критично оцінювали якраз дії органів влади, але суворого контролю з боку суду також заслуговують вчинки, які стосуються мовлення, спрямованого на протидію таким звинуваченням, оскільки вони є частиною тієї ж дискусії. Це особливо важливо в тому разі, коли, як у цьому випадку, заяви було зроблено обраними представниками професійних асоціацій у відповідь на звинувачення, що ставлять під сумнів практику та доброчесність професії (п. 44).

Далі в процесі Суд встановив, що питання викликає тривалі та бурхливі публічні дебати в Норвегії щодо розслідування звинувачень поліції стосовно насильства, особливо в місті Берген. Оскаржувані фракти викликають серйозне суспільне занепокоєння. Однак навіть у дискусіях щодо таких важливих питань має бути обмежено права на свободу вираження поглядів, якщо вони зачіпають свободи, викладені в ч. 2 конвенційної ст. 10. Тож, виступаючи з важливих питань, заявники мали діяти в межах, встановлених, серед іншого, в інтересах «захисту репутації чи прав інших людей». Отже, визначальним $є$ питання, чи були перевищені межі допустимої критики. Розв'язуючи це питання, Суд особливу увагу приділив словам, що вживалися у висловлюваннях, та до контексту, в якому їх було складено. Що стосується звинувачення авторів книги у навмисній брехні, Суд погодився з урядом, що то було перевищенням меж допустимої критики. Це може розглядатися як твердження, для яких не було фактичних підстав, і його не можна було виправдати способом висловлювань авторів. 3 іншого боку, на відміну від національних судів, Суд вказує на хибність позиції національних судів, за якою критичні твердження заявників сприймаються як твердження про факти, що вимагають від заявників доведення своєї правдивості. Насправді з фрормулювань тверджень і з їхнього контексту очевидно, що вони мали намір передати власні думки заявників і, відповідно, були досить схожі на ціннісні судження. На переконання Суду, з урахуванням його активності як призначеного урядом експерта автора книги можна порівняти 3 політиком, якому довелося проявляти більший ступінь толерантності. Тим більше, що у своїй книзі, спрямованій проти системи і значною мірою також проти певних осіб, він використав низку зневажливих виразів, такі як «дезінформація», «деспотія» та «злочинна субкультура». Тож, на думку Суду, ступінь перебільшення треба допускати в умовах такого гарячого і тривалого публічного обговорення справ, що викликають загальний інтерес, з обох сторін, тим більше, коли професійну репутацію було поставлено на карту. Отже, ЄСПЛ визнав, що заявники переважно не перевищували межі допустимої критики для цілей ст. 10 Конвенції. Тож втручання в здійснення заявниками свободи вираження поглядів було непропорційним до законної мети захисту репутації автора книги і становило порушення ст. 10 Конвенції (п. 48-50).

Висновки. Як бачимо, підхід Європейського суду щодо цього однозначний і усталений. То чи застосовує його українське національне правосуддя? Мусимо констатувати, що ні. У нас превалюють корпоративні та кумівські відносини між представниками влади та бізнесу, яким докучають журналісти та дописувачі, з одного боку, і суддями - з іншого. Тому питання в судах продовжують розв'язуватися по-свійському, часто за телефонним дзвінком або на корупційних засадах. Таке життя й такі реалії. Недарма вже багато років (попри проведення численних «рефрорм судочинства») несправедливий український суд вказується як основна причина наших негараздів, як національними політиками, так і міжнародною елітою. А що ж влада, адже щороку ЄСПЛ ухвалює нові рішення, у яких визнає дії України як відповідача непропорційними щодо обмеження прав журналістів та незаконними вердикти судів, що підтримали такі дії. То, може, влада вже якось відреагує на ці принизливі регулярні звинувачувальні рішення ЄСПЛ? Нi, скажу я вам, не відреагує. I тому є серйозні причини. Річ у тім, що в Україні щороку на замовлення багатіїв і можновладців виносяться багато несправедливих рішень про обмеження права людини на вільне вираження своїх думок і переконань. Далеко не всі з тих осіб, які були обмежені, зможуть пройти довгий шлях до Європейського суду (наше судочинство одне з найтриваліших у світі і доволі дороге), отже, до міжнародної інституції звертається принаймні $1 \%$ потерпілих від сваволі. Але й це ще не все. ЄСПЛ приймає до розгляду лише 3 \% скарг українців, решту - повертає, не мотивуючи цей крок. Тож три сотих відсотка реально потерпілих зможуть знайти європейський захист своїх порушених прав, і то це відбудеться лише 
через у середньому сім років. Тож влада цими питаннями взагалі не переймається. А розв'язання питання лежить у площині коригування внутрішнього законодавства, зокрема встановлення критеріїв дифамаційного порушення приватних прав особи та жорсткої відповідальності суддів за незаконне обмеження свободи слова.

\section{Список використаної літератури:}

1. Про друковані засоби масової інформації (пресу) в Україні : Закон України від 16 листопада 1992 р. № 2782-XII. URL: http://zakon3. rada.gov.ua/laws/show/2782-12.

2. Твердохліб О.С. Дифрамація в публічній сфері України та проблеми її подолання. Університетські наукові записки. 2017. № 64. С. 35-45.

3. Зайцев Ю. Утаємничення інформації - табу для журналіста? (Європейський аспект). Законодавчий бюлетень. 2011. № 2. С. 12.
4. Постанова Великої Палати Верховного Суду від 12 травня 2020 р. у справі № 760/18306/18. URL: http://www.reyestr.court.gov.ua/Review/ 89251594.

5. Рішення ЄСПЛ від 25 червня 1992 р. у справі «Торгерсон проти Ісландії» (Thorgeir Thorgeirson v. Iceland), заява № 13778/88. URL: http://www.humanrights.is/static/files/Itarefni/ torgeir_torgeirson_gegn_islandi.pdf.

6. Рішення ЄСПЛ від 26 квітня 1995 р. у справі «Прагер та Обершлік проти Австрії» (Prager and Oberschlick v. Austria) (№ 1), заява № 15974/90. URL: https://www.juridice.ro/wp-content/uploads/ 2016/07/prager_and_oberschlick_v_austria.pdf.

7. Рішення ЄСПЛ від 25 листопада 1999 р. у справі «Нільсен і Йонсен проти Норвегії» (Nilsen and Johnsen v. Norway), заява № 23118/93. URL: https://opil.ouplaw.com/view/10.1093/law:ihrl/ 2814echr99.case.1/law-ihrl-2814echr99.

\section{Guyvan P. D. Legal regulation of liability for defamation, its relationship with freedom of speech}

This scientific article is devoted to the study of the topical issue of combating defamation as a negative social phenomenon and the essential separation of such illegal manifestations from the proper exercise of the right of a person through the media to freely express their thoughts, ideas and views. The paper argues that it is through the mass media that the public assimilation of information takes place, and in this way the regulation of legal, social and political behavior is carried out, and the acceptability of ethical, cultural and moral traditions is guaranteed. At the same time, the exercise of the powers of journalistic freedom presupposes the possibility of expressing not only tolerant and favorable opinions, but also information that sometimes shocks and causes concern and concern. Moreover, active public discussion involves the use of a certain exaggeration or even provocation in the media. Such are the requirements of tolerance, pluralism and breadth of views declared by the Convention for the Protection of the Rights of the Person and Fundamental Freedoms, without which a democratic society is impossible. But the use of the media should not be accompanied by abuse. This means that freedom of the media imposes certain responsibilities on society. They are necessary to provide reliable information, to check it before dissemination, to ensure maximum completeness of information, to guarantee the objective presentation of messages, as any distortion or distortion of information is unacceptable. Failure to comply with positive obligations and, as a result, violations of the rights and freedoms protected by the state will result in restrictions on the right to freedom of expression and liability before the law. Sometimes it is not easy to determine the basis for it and to separate illegal activity from legitimate one. It is necessary to use the criteria developed by the European Court of Human Rights for the application of anti-defamation rules and at the same time restrict the right to freedom of expression in clearly defined cases. But the following basic factors must be taken into account: restrictive rules must be established by law, be predictable, have a legitimate aim and are necessary in a democratic society.

Key words: freedom of speech, responsibility for defamation, mass media. 


\section{ПАЙОВА (КООПЕРАТИВНА) ФОРМА ІНВЕСТУВАННЯ В БУДІВНИЦТВО}

Стаття присвячена такій пайовій формі інвестування в будівництво, як кооперативна. На підставі детального вивчення законодавства та теоретичних розробок вітчизняних правників аналізуються різні підходи до розуміння поняття житлового та житлово-будівельного кооперативу.

Автор обгрунтовує, що договір про пайову участь у житлово-будівельному кооперативі за своєю правовою природою є інвестиційним, а асоційований член такого кооперативу інвестором. Член житлово-будівельного кооперативу здійснює інвестиційну діяльність шляхом внесення грошового паю в кооператив.

У роботі критикується договірна практика, коли інвестор отримує збудовану квартиру у власність безпосередньо від забудовника, а не від кооперативу. Автор звертає увагу на ризики, пов'язані з реалізацією аналізованої форми інвестування в будівництво. До таких належить можливість подвійного продажу квартири. Із цього приводу наводиться судова практика.

У статті аналізується складна структура договірних відносин між інвестором, житлово-будівельним кооперативом та забудовником. Обгрунтовується висновок, що інвестор не має безпосереднього впливу на забудовника, що часто призводить до порущення прав такого інвестора.

Досліджено правову природу відносин з управління та членських майнових відносин у житлово-будівельному кооперативі. Автор обгрунтовує висновок, що такі відносини включають як зобов'язальні, так і речові відносини. Зокрема, обов'язку члена житлово-будівельного кооперативу сплатити пай кореспондується право вимоги кооперативу щодо його виконання і виключення з кооперативу в разі невиконання. Обов'язку житлово-будівельного кооперативу передати в користування (при повній виплаті паю - у власність) квартиру відповідно до розміру паю відповідає право члена кооперативу вимагати надання квартири чи виплати вартості належного йому паю в разі виходу або виключення з кооперативу.

Акцентовано увагу на недосконалості фрормулювань, ужитих у ст. 384 ЦК України в частині права інвестора викупити побудовану квартиру. Адже асоційований член кооперативу, виплативши відповідний пай, отримує майнове право щодо передачі квартири у власність. Тому в такому разі підставою виникнення права власності на квартиру $є$ власне договір пайової участі (інвестиційний договір), а не договір купівлі-продажу квартири.

Ключові слова: пайова (кооперативна) фоома інвестування, житлово-будівельний кооператив, інвестиції, майнові права на квартиру.

Постановка проблеми. Закон України «Про інвестиційну діяльність» [1] визначає вичерпний перелік форм інвестування та фрінансування будівництва об'єктів житлового будівництва з використанням недержавних коштів, залучених від фрізичних та юридичних осіб. Кооперативна фрорма, не будучи передбаченою зазначеним вище законом, реалізовується на підставі спеціального нормативного акта - Закону України «Про кооперацію» [2]. Незважаючи на те, що кооперативна діяльність має давню історію розвитку, з еволюцією економічних та юридичних процесів ії значення залишається вагомим.
Аналіз останніх досліджень і публікацій. Питання правового статусу, створення та функціонування житлово-будівельних кооперативів були предметом багатьох досліджень вітчизняних правників. Серед них варто виокремити М.К. Галянтича, В.І. Борисову, В.П. Янишена, Д.Д. Позову.

Метою цієї статті $є$ дослідження діяльності житлово-будівельних кооперативів у контексті залучення інвестицій у будівництво житла, аналіз правових відносин, які виникають між асоційованими пайовиками та самим житлово-будівельним кооперативом, а також дослідження 
правових механізмів договірного типу, за допомогою яких інвестори отримують у власність об'єкт інвестування.

Виклад основного матеріалу. Однією з перших фрорм пайової участі в будівництві, які залишаються актуальними і сьогодні, $є$ кооперативні. Відповідно до Закону України «Про кооперацію» кооператив $є$ юридичною особою, утвореною фізичними та/або юридичними особами, які добровільно об'єдналися для ведення спільної господарської та іншої діяльності з метою задоволення своїх економічних, соціальних та інших потреб на засадах самоврядування.

Загальне визначення кооперативу конкретизується в положеннях законодавства, яке регулює окремі види кооперативів. Серед них - житлово-будівельний, який створюється на основі договору між інвесторами - пайовиками, про пайову участь у кооперативі. Правила утримання житлових будинків і прибудинкових територій містить таке визначення житлово-будівельного кооперативу: це юридична особа, утворена фізичними i/або юридичними особами, які добровільно об'єдналися на підставі їхніх майнових внесків для участі в будівництві або реконструкції житлового будинку (будинків) і подальшої їх експлуатації [3].

Житлові та житлово-будівельні кооперативи $\epsilon$ особливою формою самоорганізації членів кооперативу, на відміну від інших організаційно-правових форм, що передбачає приватне утримання багатоквартирних жилих будинків. Різниця полягає в тому, що метою житловобудівельного кооперативу $є$ забезпечення ленів кооперативу житлом, якого вони потребують, а отже, після завершення будівництва для обслуговування й управління жилим будинком і прилеглою територією може бути створено житловий кооператив [4, с. 125].

Д.Д. Позова розглядає житлово-будівельний кооператив як вид споживчого кооперативу [5, с. 15], В.І. Борисова та В.П. Янишен - як обслуговуючий [6, с. 15]. М.К. Галянтич акцентує на тому, що такі кооперативи є особливими формами непідприємницьких товариств, метою яких у житловій сфері $є$ задоволення не лише житлових, а й економічних, соціальних та інших потреб членів кооперативу завдяки поєднанню їхніх особистих і колективних інтересів, поділу між ними ризиків, витрат і доходів на основі самоорганізації, самоуправління та самоконтролю за використанням житлового фонду [7, с. 120].
Цікаву думку висловила О.П. Ковальова. Так, житлово-будівельний кооператив $\epsilon$ особливим учасником господарської діяльності у сфері будівництва житла, діє як квазісуб'єкт господарської діяльності з боку як замовника, так і підрядника, не може належати до жодного з видів кооперативів [8, с. 117].

За умовами договору про пайову участь в житлово-будівельному кооперативі інвестор зобов'язується внести майновий внесок у вигляді грошових коштів, а інша сторона зобов'язується передати пайовику (інвестору) зумовлену договором кількість житлової площі у квартирі пропорційно розміру внесеного паю.

Цей договір за своєю правовою природою $\epsilon$ інвестиційним. Хоч житлово-будівельний кооператив як юридична особа - сторона договору, не $є$ виконавцем будівельних робіт. Житлово-будівельний кооператив укладає підрядний договір із безпосереднім виконавцем робіт. Але це не впливає на інвестиційний характер відносин сторін.

Як зазначає М.В. Скаржинський, під договором інвестування в будівництві житла на умовах дольової участі потрібно розуміти договір, за яким інвестор (довіритель, замовник) зобов'язується передати грошові кошти в оплату фактичної вартості будівництва житла, а виконавець (повірений) приймає на себе функції замовника будівництва певного об'єкта нерухомості і кошти інвестора із зобов'язанням передати останньому у власність обумовлене договором житло (квартири) на умовах цього договору, тобто протягом визначеного строку по закінченню будівництва і здачі будинку в експлуатацію [9, с. 135].

Відносини між інвестором (членом житлово-будівельного кооперативу), кооперативом і підрядником (виконавцем) будівельних робіт мають складну структуру. Однак, незважаючи на різні найменування договорів між названими особами, вони мають ознаки інвестиційних договорів. На цю особливість звертає увагу В.А. Січевлюк, підкреслюючи, що інвестиційний договір на будівництво житла є різновидом інвестиційного договору, який має специфічний об'єкт, предмет, особливий суб'єктний склад, специфічний порядок та строк дії договору. Виходячи з особливостей, властивих інвестиційним відносинам, автор обґрунтовує таке поняття інвестиційного договору на будівництво житла: це цивільний договір, на підставі якого одна сторона - інвестор, зобов'язується передати інвестиції реципієнту та прийняти у власність житло, а інша сторона, реципієнт, зобов'я- 
зується прийняти, використати або направити інвестиції на будівництво житла та передати інвестору документи, необхідні для реєстрації ним права власності [10, с. 7].

Договори, на підставі яких здійснюється придбання у власність об'єкта житлової нерухомості, мають інвестиційний характер, а особа, яка владає кошти, $€$ інвестором. Відмінності в термінологічному апараті залежить від форми інвестиційної діяльності. Доцільно уніфікувати поняттєвий апарат у сфрері будівництва житла, встановлюючи однакові гарантії захисту прав інвесторів у зазначеній царині відносин.

Розмір паю відповідає сумі інвестицій у придбання квартири. Член житлово-будівельного кооперативу фрактично здійснює інвестиційну діяльність шляхом внесення грошового паю в кооператив, з яким він перебуває у договірних відносинах, а останній передає інвестору квартиру у власність.

Таким чином, житлово-будівельний кооператив як суб'єкт правовідносин виконує певною мірою посередницькі фрункції. На практиці доволі часто договори участі в житлово-будівельному кооперативі містять умови про передачу квартири члену кооперативу безпосередньо, без оформлення навіть права власності на сам кооператив. Тобто має місце пряма передача майна від забудовника інвесторові після введення об'єкта будівництва в експлуатацію. При цьому первинним власником житла стає інвестор - член кооперативу, а не сам кооператив. Так, за умовами договору про спільну пайову участь у будівництві багатоквартирного житлового будинку із ЖБК «Нова Ера-108» (забудовник) останній мав право залучати грошові кошти та інше майно юридичних і фрізичних осіб для будівництва житлового будинку, не порушуючи при цьому прав пайовиків. Після закінчення будівництва об'єкта передавав квартиру пайовику за актом прийому-передачі, а пайовик зобов'язувався внести пайовий внесок на будівництво квартири в розмірі та порядку, передбаченому договором, і набував належну йому частку в будівництві у вигляді квартири на основі акту прийому-передачі [11].

Такі договори не відповідають суті правових відносин між житлово-будівельним кооперативом та його членами. Забудовники за допомогою використання такої договірної конструкції порушують норми Закону України «Про інвестиційну діяльність», які забороняють здійснювати інвестування в об'єкти житлової забудови з використанням недержавних коштів, залуче- них від фрізичних осіб способами іншими, ніж установлені законом. Фактично під виглядом участі в житлово-будівельному кооперативі укладався договір із забудовником.

До внесення змін до Закону України «Про кооперацію» та затвердження Порядку державної реєстрації прав на нерухоме майно та їх обтяжень суди визнавали недійсними такі договори 3 посиланням на порушення ч. 3 ст. 4 Закону України «Про інвестиційну діяльність», а також близькі до них за змістом договори про пайову участь у будівництві житла. При цьому, згідно із судовою практикою суди розглядали договори про пайову участь у будівництві як удавані правочини. До відносин сторін у цьому випадку застосовувалися норми, що регулюють той правочин, який дійсно сторони мали на увазі, а саме - інвестиційний договір [12].

Питання розмежування договірних фрорм, які опосередковують інвестиційну діяльність, має важливе значення для захисту прав інвесторів у будівництві. Житлово-будівельний кооператив $\epsilon$ власником як квартири, так і багатоквартирного будинку в цілому до часу сплати членом кооперативу визначеного договором внеску. Оскільки інвестори, які беруть участь в кооперативі, включаються до складу асоційованих членів, то вони відповідно до законодавства про кооперацію не беруть участь в управлінні справами такого кооперативу і не впливають на ухвалення рішень, пов'язаних із розпорядженням майном. Найвищим органом управління житлово-будівельним кооперативом $є$ загальні збори і правління, які можуть без згоди інвестора ухвалити рішення, яке суперечить його інтересам.

Зокрема, непоодинокими є випадки подвійного продажу квартир, оскільки їх облік житлово-будівельний кооператив веде самостійно. Тому можливий варіант, коли одну і ту квартиру продають різним особам. Така ситуація описується в постанові Верховного Суду від 02.10.2019 № 520/7188/15-ц [13].

Житлово-будівельний кооператив як самостійна юридична особа може залучати кредитні кошти для фрінансування спорудження будинку. У разі неспроможності вчасно повернути кредит житлово-будівельний кооператив несе відповідальність належним йому майном. Банк може звернути стягнення за кредитним та іпотечним договорами на об'єкт інвестування.

Таким чином, окрім способів залучення недержавних коштів на фінансування будівництва, передбачених Законом України «Про інвестиційну діяльність», застосовується ще один 
механізм - шляхом укладення договорів про пайову участь у будівництві з житлово-будівельними кооперативами. Однак здійснення інвестицій в будівництво житла зазначеним способом має значні ризики, оскільки відносини складаються між інвестором та житлово-будівельним кооперативом. А останній укладає договір безпосередньо із забудовником. Відповідно, інвестор не має правового впливу безпосередньо на забудовника. Тому права та інтереси інвесторів часто порушуються.

Представляє інтерес правова природа відносин 3 управління та членських майнових відносин у житлово-будівельному кооперативі. Членські майнові правовідносини включають у себе як зобов'язальні, так і речові відносини. Відносини із приводу сплати паю членом кооперативу та надання йому квартири $є$ двостороннім зобов'язанням. Так, обов'язку члена житлово-будівельного кооперативу сплатити пай кореспондується право вимоги кооперативу щодо його виконання і виключення 3 кооперативу в разі невиконання. Обов'язку житлово-будівельного кооперативу передати в користування (при повній виплаті паю - у власність) квартиру відповідно до розміру паю відповідає право члена кооперативу вимагати надання квартири чи виплати вартості належного йому паю у разі виходу або виключення з кооперативу. Тому Д.Д. Позова звертає увагу на необхідність розмежування відносин щодо надання квартири з відносинами щодо її використання: перші мають зобов'язальний характер, а другі обмежено речовий [5, с. 11]. На комплексності цивільних правовідносин, які виникають внаслідок членства в житлово-будівельній кооперації, наголошує М.К. Галянтич [7, с. 120].

Особливість пайової участі в житлово-будівельному кооперативі полягає в тому, що згідно зі ст. 384 ЦК України будинок, споруджений або придбаний житлово-будівельним кооперативом, $є$ його власністю. Член житлово-будівельного (житлового) кооперативу має право володіння, користування, а за згодою кооперативу - розпорядження квартирою, яку він займав у будинку кооперативу, якщо він не викупив ії. I лише в разі викупу квартири член кооперативу стає її власником.

Законом України «Про внесення змін до Закону України «Про кооперацію» щодо набуття членами кооперативу права власності» [14], були внесені зміни до названого закону шляхом доповнення ст. 191, згідно з якою член житлово-будівельного, дачно-будівельного, гараж- но-будівельного, житлового, дачного, гаражного чи іншого відповідного кооперативу має право володіння, користування, а за згодою кооперативу - і розпоряджання квартирою, дачею, гаражем, іншою будівлею, спорудою або приміщенням кооперативу, якщо він не викупив це майно.

У разі викупу квартири, дачі, гаража, іншої будівлі, споруди або приміщення член житлово-будівельного, дачно-будівельного, гаражно-будівельного, житлового, дачного, гаражного кооперативу чи іншого відповідного кооперативу стає власником цього майна. Право власності на таке майно у члена кооперативу виникає з моменту державної реєстрації цього права відповідно до закону.

Аналіз законодавчих положень свідчить, що член житлового кооперативу (пайовик) має право на свій внесок (пай), що є фактично інвестицією в об'єкт будівництва. Але право власності на квартиру він отримає після внесення суми, яка відповідає вартості квартири.

Законодавець у ст. 384 ЦК України використовує термін «викуп квартири членом житлово-будівельного кооперативу». Цей термін не зовсім відповідає суті інвестиційних відносин пайової участі в житлово-будівельному кооперативі. Інвестувавши вартість квартири, пайовик має майнове право вимоги до житлово-будівельного кооперативу щодо передачі квартири у власність. Термін «викуп квартири» асоціюється із цивільно-правовими договорами купівлі-продажу або оренди житла з викупом. Натомість іншою $є$ правова природа інвестиційних договорів. Інвестиційні договори $є$ фрормою залучення коштів для вкладення в об'єкт інвестиційної діяльності, що пов'язано з певним ризиком. У такому разі необхідно визначитися із правовою підставою виникнення права власності в інвестора на об'єкт будівництва - квартиру. Тим більше, що законодавством право власності на об'єкт нерухомості пов'язується з його державною реєстрацією.

Складається парадоксальна ситуація, коли інвестор сплачує повністю інвестиційний внесок, який відповідає вартості квартири в житлово-будівельному кооперативі, а первинним власником вважається сам кооператив. Після введення будинку в експлуатацію квартира набувається інвестором у власність.

Викуп як правова підстава набуття права власності інвестором може мати місце тоді, коли пайовик вніс останній внесок після введення будинку в експлуатацію. Інвестиційний договір разом із підтверджуючим документом 
про сплату повної вартості квартири, виданим органом управління житлово-будівельного кооперативу повинен бути підставою набуття права власності та його державної реєстрації. Відповідно необхідно змінити редакцію ч. 2 та 3 ст. 384 ЦК України, об'єднавши їх та виклавши в такій редакції: «Член житлово-будівельного житлового кооперативу має право володіння, користування, а за згодою кооперативу - розпорядження квартирою, яку він займає в будинку кооперативу, а після сплати повної вартості набуває право власності на неї».

Така зміна буде більш ефективно забезпечувати права члена житлово-будівельного кооперативу. Адже інвестори, які беруть участь у житлово-будівельному (житловому) кооперативі, не беруть участі в управлінні справами кооперативу, реалізуючи свої повноваження через органи управління останнього. Збори членів кооперативу, за наявності кворуму, можуть відбуватися без участі асоційованого члена кооперативу та ухвалювати рішення щодо доплат до вартості вимірної одиниці відповідної квартири, передання в іпотеку незавершеного будівництва для отримання кредиту тощо. Одним із порушень майнових прав інвесторів - пайовиків житлово-будівельного кооперативу, є продаж квартири іншій особі без відома інвестора, посилаючись на несвоєчасну сплату пайових внесків. Тому «прив'язка» сплати повної вартості квартири в житлово-будівельному кооперативі до набуття ії у власність буде ще однією умовою забезпечення прав та інтересів інвестора від можливих порушень.

Висновки і пропозиції. Однією з форм пайової участі в будівництві $€$ кооперативна. Між житлово-будівельним кооперативом та інвестором (асоційованим пайовиком) укладається договір про пайову участь у кооперативі. Внесок (пай) члена житлово-будівельного кооперативу $€$ інвестицією в об'єкт будівництва, право власності на який він отримає після внесення суми, яка відповідає вартості квартири. Законодавець у ст. 384 ЦК України використовує термін «викуп квартири членом житлово-будівельного кооперативу». Цей термін не відповідає суті інвестиційних відносин пайової участі в житлово-будівельному кооперативі. Інвестувавши вартість квартири, пайовик має майнове право вимоги до житлово-будівельного кооперативу щодо передачі квартири у власність.

Викуп як правова підстава набуття права власності інвестором може мати місце в разі внесення останнього пайового внеску від- повідно до вартості інвестиційного об'єкта. Інвестиційний договір разом із підтверджуючим документом про сплату повної вартості квартири, виданим органом управління житлово-будівельного кооперативу, повинен бути підставою набуття права власності та його державної реєстрації. У зв'язку із цим пропонуються змінити редакцію ч. 2 та 3 ст. 384 ЦК України, об'єднавши їх та виклавши в такій редакції: «Член житлово-будівельного житлового кооперативу має право володіння, користування, а за згодою кооперативу - розпорядження квартирою, яку він займає в будинку кооперативу, а після сплати повної вартості набуває право власності на неї».

\section{Список використаної літератури:}

1. Про інвестиційну діяльність : Закон України від 18.09.1991 № 1560-XII. Дата оновлення: 20.10.2019. URL : https://zakon.rada.gov.ua/ laws/show/1560-12\#Text (дата звернення 01.06.2020).

2. Про кооперацію : Закон України від 10.07.2003 № 1087-IV. Дата оновлення: 06.11.2014. URL : https://zakon.rada.gov.ua/laws/ show/978-15\#Text (дата звернення 25.05.2020).

3. Правила утримання жилих будинків та прибудинкових територій: наказ Державного комітету України з питань житлово-комунального господарства від 17.05.2005 № 76. Дата оновлення: 17.05.2005. URL : https://zakon.rada.gov.ua/ laws/show/z0927-05\#Text (дата звернення: 16.05.2017).

4. Малохліб О. Проблемні питання виникнення земельних прав житлово-будівельних кооперативів. Национальный юридический журнал: теория и практика. 2017. № 1. С. 125-129.

5. Позова Д.Д. Правове становище житловобудівельних кооперативів за законодавством України : автореф. дис. ... канд. юрид. наук : 12.00.03. Одеса, 2012. 20 с.

6. Борисова В.І., Янишен В.П. Житлово-будівельні кооперативи: минуле та сучасність. Актуальні проблеми приватного права: матеріали наук.-практ. конф., присвяч. 94 річниці з дня народження В.П. Маслова. Харків, 19 лютого 2016 р. Харків, 2016. С. 12-16.

7. Галянтич М.К. Правовий статус житлово-будівельного кооперативу як непідприємницького товариства. Приватне право $і$ підприємництво. 2013. Вип. 12. С. 119-123.

8. Ковальова О.П. Особливості організаційно-господарського забезпечення діяльності житлово-будівельних кооперативів. Вісник Національного університету «Юридична академія України імені Ярослава Мудрого». 2012. № 4(11). С. 112-119. 
9. Скаржинський М.В. Житло як об'єкт цивільно-правових відносин : дис. ... канд. юрид. наук : 12.00.03. Київ, 2006. $221 \mathrm{c}$.

10.Січевлюк В.А. Інвестиційні договори на будівництво житла (цивільно-правовий аспект) : автореф. дис. ... канд. юрид. наук : 12.00.03. Київ, 2003. 20 c.

11. Договір про спільну пайову участь у будівництві багатоквартирного житлового будинку житлово-будівельного кооперативу «Нова Ера-108». URL : http://man-bud.com.uа (дата звернення: 16.05.2017).
12.Блажко Р. Інвестування в житло через зал судового засідання. URL : https://flexp.com.ua/ library/article/95 (дата звернення: 16.05.2017).

13.Постанова Верховного Суду від 02.10.2019 № 520/7188/15-ц. URL : http://www.reyestr.court.gov. ua/Review/84845621 (дата звернення: 05.04.2020).

14.Про внесення змін до Закону України «Про кооперацію» щодо набуття членами кооперативу права власності : Закон України від 04.06.2009 1448-VI. Дата оновлення: 04.06.2009. URL : https://zakon.rada.gov.ua/laws/show/144817\#Text (дата звернення 25.04.2016).

\section{Rym T. Ya. Share (cooperative) form of investment in construction}

The article is devoted to such a share form of investment in construction as cooperative. Based on a detailed study of the legislation and theoretical researches of domestic lawyers, various approaches to understanding the concept of housing cooperative are analyzed.

The author substantiates that the agreement on participation in a housing cooperative is an investment, and an associate member of such a union - an investor. A member of a housing cooperative carries out investment activities by contributing a money share to the collective.

The paper criticizes the contractual practice when the investor becomes an owner of the built apartment directly from the developer, but not from the cooperative. The author draws attention to the risks connected with the implementation of the analyzed form of investment in construction. These include the possibility of a double sale of the apartment. The judicial practice is cited in this regard.

The article analyzes the complex structure of contractual relations between the investor, housing cooperative, and the developer. The conclusion is substantiated that the investor does not have a direct influence on the developer, which often leads to a violation of the rights of such an investor.

The legal nature of management relations and membership property relations in a housing cooperative is studied. The author substantiates the conclusion that such connections include both obligatory and material relationships. In particular, the obligation of a member of a housing cooperative to pay a share corresponds to the right of the cooperative to demand its fulfillment and exclusion from the collective in case of non-fulfillment. The obligation of the housing cooperative to transfer the apartment for use (with full payment of the share - ownership) under the size of the share corresponds to the right of the cooperative member to demand the provision of the apartment or payment of the share due to him in case of exit or exclusion from the cooperative.

Emphasis is placed on the imperfections of the wording used in Art. 384 of the Civil Code of Ukraine regarding the right of the investor to buy the built apartment. After all, an associate member of the cooperative, having paid the appropriate share, receives the property right to transfer the residence to the property. Therefore, a contract of participation (investment agreement) is the basis for the ownership of the apartment, but not a contract of sale of the residence.

Key words: share (cooperative) form of investment, housing cooperative, investments, property rights to an apartment. 


\title{
УДК 347.91/.95
}

DOI https://doi.org/10.32840/1813-338X-2020.3.7

\author{
Н. А. Сергієнко \\ кандидат юридичних наук, \\ старший викладач кафедри публічного та приватного права \\ Київського університету імені Бориса Грінченка, \\ адвокат
}

\section{ЗЛОВЖИВАННЯ ПРАВАМИ У ВИКОНАВЧОМУ ПРОЦЕСІ}

Наукова стаття присвячена проблематиці зловживання правами у виконавчому процесі. Автором статті проаналізовано основні точки зору науковців-юристів до поняття та суті зловживання правами в цілому, зловживання правами в судових процесах, виконавчому процесі. У ході наукового дослідження автор дискутує з іншими дослідниками-юристами, зокрема щодо питання про можливість зловживання правами виключно у формі дій; щодо суті зловживання правами, зокрема у виконавчому процесі, як їх реалізації усупереч правам та інтересам інших суб'єктів цих відносин. Автор статті аргументує, що зловживання правами у виконавчому процесі можливе як у фрормі дій, так і у фрормі бездіяльності. У науковій статті наводяться приклади зловживань правами у виконавчому процесі у формі бездіяльності. Автор статmі обгрунтовує, що суть зловживання правами не може зводитись до вчинення відповідними суб'єктами дій усупереч правам та інтересам інших суб'єктів виконавчого провадження. Адже іноді такі суб'єкти мають прямо протилежні інтереси, а свої права у виконавчому провадженні реалізують на власний розсуд. Останнє корелюється із принципом диспозитивності як одним із принципів виконавчого провадження (див. п. п. 4 ч. $1 \mathrm{~cm}$. 2 Закону України «Про виконавче провадження»). У науковій статmі автор пропонує розуміти під зловживаннями правами у виконавчому процесі реалізацію суб'єктами виконавчого процесу своїх прав, у той час коли здійснюється примусове виконання рішення, з єдиною метою - спричинити шкоду іншому суб'єкту (іншим суб'єктам) виконавчого процесу. У науковій статті резюмується, що будь-який суб'єкт виконавчого процесу може зловживати своїми правами, які в нього наявні як у суб'єкта виконавчого процесу. Про таке зловживання може йтися, коли свої права такий суб'єкт реалізує виключно для того, щоб нашкодити іншому суб'єкту (суб'єктам) виконавчого процесу. Автор статті зауважує про те, що подальші наукові дослідження теми зловживанням правами у виконавчому процесі $\epsilon$ актуальними. Зокрема, на думку автора, перспективним було б вироблення алгоритму запобігання зловживання правами у виконавчому процесі.

Ключові слова: виконавче провадження, зловживання суб'єктивними правами, суб'єкти виконавчого процесу, виконавець, стягувач, боржник.

Постановка проблеми. Тематика зловживання правами привертає увагу юристів-дослідників вже давно. Так, приклади та аналіз шикани можна зустріти ще в римському праві. Актуальною $є$ ця тема і для процесуальних галузей - цивільного, господарського, адміністративного, виконавчого процесів. I якщо в межах судових юрисдикційних діяльностей тема зловживання правами опрацьована більш широко (приписи про заборону зловживання процесуальними правами містять чинні ЦПК України, ГПК України, КАС України, наявні коментарі науковців-юристів щодо цих положень, наявна судова практика застосування відповідних приписів наведених актів процесуального законодавства), то тема зловживання правами у виконавчому процесі залишається набагато менш дослідженою серед науковців-правників. А щодо приписів законодавства, яке регулює виконавчий процес, то приписів, які б стосувались заборони зловживання правами у виконавчому процесі, немає. Наведене зумовлює актуальність наукової статті за темою зловживання правами у виконавчому процесі.

Аналіз останніх досліджень і публікацій. Тематика зловживання правами відображена в наукових роботах М.Й. Покровського, О.О. Малиновського, окремі питання зловживання процесуальними правами були досліджені В.В. Комаровим, Г.І. Марунич, О.С. Снідевичем. Комплексне дослідження зловживання правами в цивільному та виконавчому проце- 
сах здійснено в дисертаційному дослідженні О.М. Кузнеця. У працях інших вчених-юристів також можна віднайти ті чи інші аспекти дослідження зловживання правами (наприклад, у роботах А.В. П'ятницького, Ю.О. Євтошук та інших науковців-юристів). Проте вважати цю тему повністю дослідженою було б передчасно, адже із плином часу юридична наука поповнюється новими науковими концептами, змінюються приписи законодавства. Тож новий погляд на тему зловживання правами у виконавчому процесі вбачається доцільним.

Мета статті полягає в тому, щоб дослідити суть зловживання правами у виконавчому процесі, а завдання статті такі: з'ясувати чи можна зловживати процесуальними правами у виконавчому процесі через бездіяльність та хто може бути суб'єктом зловживання правами у виконавчому процесі.

Виклад основного матеріалу. Тема зловживання правом є доволі неновою в юридичній науці та була розглянута значною кількістю вчених-юристів в різних контекстах. Наприклад, В.П. Камишанський та Н.Ю. Ветер зазначають, що під зловживанням суб'єктивним правом як межею здійснення цивільних прав варто розуміти допустиму міру дій суб'єкта цивільного права під час вибору варіанта реалізації своїх можливостей, які містяться у змісті суб'єктивного цивільного права для задоволення свого приватного інтересу співрозмірно з індивідуальним розумінням соціальних і правових обмежень [1, с. 19]. Тут варто підкреслити, що наведені автори ведуть мову про те, що в контексті зловживання суб'єктивними правами йдеться саме про дії відповідного суб'єкта. У цьому ж контексті наголошує й Г.І. Марунич: зловживання процесуальними правами, як і зловживання правами взагалі, може мати місце лише у вигляді дій, але не бездіяльності [2, с. 117]. Розгляд зловживань правами саме в розрізі дій прослідковується у працях В.В. Комарова та інших вчених-юристів: основна ознака зловживання процесуальними правами полягає в тому, що дії, які їі складають, вчиняються на зовні законній юридичній підставі [3, с. 412]. Дещо інші умовиводи можна віднайти в А.В. П'ятницького, зокрема, наведений автор, визначаючи ознаки, які характеризують суб'єктивні права, однією з таких ознак називає те, що поведінка суб'єкта нормативно обмежена, порушення цих меж (міри можливої поведінки) становить зловживання правом [4, с. 136]. Достатньо лаконічним, але точним, як видається,
$€$ розуміння зловживання процесуальними правами в цілому, яке пропонує, досліджуючи цивільний процес, Г.І. Марунич: на її думку, воно зводиться до реалізації наданих суб'єкту процесуальних прав всупереч меті і завданням цивільного судочинства, в тому числі тих, що стосуються темпоральних його аспектів [2, с. 26]. I дійсно, якщо відповідний суб'єкт процесуальних правовідносин реалізує надані йому процесуальні права на шкоду меті та завданням, які стоять перед тим юрисдикційним процесом, в якому він бере участь, можна вести мову, що своїми процесуальними правами він зловживає. Більш ємне визначення в контексті зловживання правами дає О.М. Кузнець, він розглядає «зловживання правами в цивільному та виконавчому процесі», під якими пропонує розуміти один із способів реалізації суб'єктами цивільних процесуальних і виконавчих процесуальних відносин їхніх матеріальних і (або) процесуальних прав усупереч правам та інтересам інших суб'єктів цих відносин і принципам справедливості, розумності, добросовісності з метою отримання додаткової моральної та (чи) матеріальної вигоди або спричинення шкоди іншій особі (особам) [5, с. 7]. Тут автор виводить цікавий концепт, що у цивільному та виконавчому процесах можливим $€$ зловживання як матеріальними, так і процесуальними правами; що полягає в їх реалізації, зокрема всупереч правам та інтересам інших суб'єктів цих відносин і принципам справедливості, розумності, добросовісності. Однак, варто підкреслити, що суб'єкти як цивільного, так і виконавчого процесу іноді мають прямо протилежні інтереси в цих процесах, наприклад, позивач та відповідач у цивільному процесі, стягувач та боржник у виконавчому процесі, вони не мають обов'язку діяти у взаємних інтересах, так само, як і погоджувати свої діяння 3 іншими сучасниками цих правовідносин. У даному випадку, варто вести мову і про реалізацію принципу диспозитивності як одного із принципів цивільного процесу, що полягає в тому числі й у тому, що учасник справи розпоряджається своїми правами щодо предмета спору на власний розсуд (ст. 13 ЦПК України). Принцип диспозитивності також $є$ одним із принципів виконавчого процесу (п. п. 4 ч. 1 ст. 2 Закону України «Про виконавче провадження»). Принцип диспозитивності лежить в основі руху виконавчого провадження, передбачаючи необхідність прояву ініціативи сторін у межах визначених законом [6, с. 38]. Одним із 
визначальних аспектів реалізації принципу диспозитивності в діях суб'єктів виконавчого провадження В.В. Золотаренко визначає те, що він полягає в можливості вільного розпорядження своїми матеріальними і процесуальними правами, необхідності виявлення ініціативи для досягнення бажаних цілей і пливу на рух виконавчого провадження [6, с. 40]. Із наведеним варто погодитись, адже, дійсно, кожен суб'єкт виконавчого процесу вправі розпоряджатися своїми правами за своїм розсудом, а забезпечувати права та інтереси інших суб'єктів цього процесу він не зобов'язаний (тут очевидна кореляція 3 конституційним приписом про те, що ніхто не може бути примушений робити те, що не передбачено законодавством, -ст. 19 Конституції України). За таких умов передчасно було б вводити в суть зловживання правами у виконавчому процесі тези, що ці права реалізуються всупереч правам інтересам інших суб'єктів цього процесу. Досить влучно суть зловживання процесуальними правами сформульовано В.В. Комаровим та деякими іншими вченими-юристами: механізм зловживання процесуальними правами полягає в тому, що особа, яка бажає мати певний юридичний результат (наприклад, відкласти судове засідання, добитися зупинення провадження у справі тощо), вчиняє процесуальні дії (бездіяльність), зовні «схожі» на ті юридичні факти, з якими пов'язується настання необхідного результату. Такі дії, однак, мають повністю штучний характер, подібно до того, як удавана угода у цивільному праві вчиняється лише для цілей прикриття іншої угоди [3, с. 412]. У цьому формулюванні автори вказують на можливість зловживання процесуальними правами як через процесуальні дії, так і через процесуальну бездіяльність. Проте, наприклад, Г.І. Марунич стверджує, про що вже йшлося вище, що зловживання процесуальними правами, як і зловживання правами взагалі, може мати місце лише у вигляді дій, але не бездіяльності [2, с. 117]. А дійсно, чи можна зловживати процесуальним правом через бездіяльність, зокрема, у виконавчому процесі? Як видається, це цілком можливо. Наприклад, приписи ч. 4 ст. 5 Закону України «Про виконавче провадження» передбачають підстави, за наявності яких виконавець не може виконувати рішення. Приписи ж ч. 1 ст. 23 Закону України «Про виконавче провадження» передбачають, що в разі виявлення обставин, передбачених ч. 4 ст. 5 цього Закону, виконавець зобов'язаний заявити самовідвід та повідомити про це стягувача. Із тих самих підстав відвід виконавцю може бути заявлений стягувачем, боржником або їхніми представниками. Отже, за наявності вищевказаних підстав виконавець зобов'язаний заявити самовідвід (це його прямий процесуальнийобов'язок), а сторони / їх представники мають право заявити йому відвід (це їх процесуальне право). Відтак якщо з певних причин самовідвід за таких підстав не заявив виконавець, то наявне правопорушення. А якщо цього не зробили сторони за даних підстав, то чи може це вважатися зловживанням процесуальним правом? Як видається, так, може. Оскільки за таких умов сторона обізнана, що умови неупередженості виконавчого провадження не дотримані, а сам виконавець це не усунув через самовідвід, отже, не заявляючи відвід виконавцю, така сторона сприяє тому, щоб виконавче провадження провадилось тим виконавцем, який не може за законом його провадити, оскільки порушується принцип неупередженості як один із принципів виконавчого провадження (п. п. 5 ч.1 ст. 2 Закону України «Про виконавче провадження»). Можна навести й ще один приклад, який ілюструє, що зловживання процесуальними правами у виконавчому процесі можливе і через бездіяльність. Зокрема, боржник не знайомиться 3 матеріалами виконавчого провадження (таке ознайомлення $є$ його процесуальним правом), свідомо не отримує кореспонденцію від виконавця (законодавство про виконавче провадження не містить такого обов'язку боржника не містить). І робить це виключно для того, щоб якнайдовше не виконувати рішення, а на випадок, якщо до його відома все ж буде доведено певну постанову виконавця тощо, він не вважався таким, що пропустив строк на її оскарження. Цікавою $\epsilon$ точка зору А.В. П'ятницького, який стверджує, що законодавець надав виконавцям занадто широке коло прав, створюючи при цьому додаткові можливості для зловживання ними своїм становищем; і як приклад наводить таке право виконавця, як «безперешкодно входити на земельні ділянки, до приміщень, сховищ, іншого володіння боржника - юридичної особи, проводити їх огляд, примусово відкривати та опечатувати їх» [4, с. 138]. Однак, як видається, проблема не в широті прав виконавців. Навіть якщо уявити, що у виконавця буде одне єдине процесуальне право, то і ним можна зловживати. Тут справа в тому, що незалежно від того, який обсяг процесуальних прав у виконавця, він їх має реалізовувати саме для досягнення 
завдання зі своєчасного, повного і неупередженого виконання рішень, примусове виконання яких передбачено законом (див. ст. 3 Закону України «Про органи та осіб, які здійснюють примусове виконання судових рішень і рішень інших органів»). Якщо ж такі права виконавець реалізує супереч вказаному завданню, чи для досягнення іншого завдання, то можливо вести мову про зловживанням ним своїми процесуальними правами у виконавчому процесі. Ю.О. Євтошук зазначає, що зазвичай зловживання дискреційними повноваженнями зумовлене, власне, вільним розсудом публічної влади та можливими видами його вияву [7, с. 109]. Важко не погодитись, що там, де $є$ дискреція, там може бути і зловживання. Резонно зазначає О.О. Чумак, що має місце встановлення «розмитих» переліків повноважень виконавчої служби [8, с. 141]. Дійсно, приписи ч. 3 ст. 18 Закону України «Про виконавче провадження» передбачають перелік прав виконавця у виконавчому процесі, а п. п. 22 цієї ж частини передбачає, що виконавець має й інші повноваження, передбаченіцим Законом. Надумку О.О. Чумака, встановлення невичерпного переліку повноважень може призводити до зловживань із боку працівників державної виконавчої служби, використання наданих повноважень для реалізації власних інтересів, проявів корупції, що є неприпустимим у правовій, демократичній державі [8, с. 141]. Але наведене ще раз свідчить, що виконавець, зокрема, має реалізовувати свої процесуальні права у виконавчому провадженні саме на досягнення завдання, яке перед ним стоїть - своєчасно, повно і неупереджено виконати рішення, яке підлягає примусовому виконанню. Науковці-юристи наводять різні приклади зловживання процесуальними правами у виконавчому процесі. Так, О.Д. Король серед них наводить зловживання стягувачем своїм правом щодо вибору місця відкриття виконавчого провадження, зловживання боржником свого права щодо недопуску виконавців для опису арештованого нерухомого майна [9, с. 104]. О.С. Снідевич веде мову про те, що існують у практиці з боку стягувачів такі ситуації, за якими стягувачі, отримавши рішення суду про поновлення на роботі, не поспішають з'являтися на роботі та приступати до виконання трудових обов'язків з огляду на те, що за відсутності наказу про поновлення працівника на роботі або недоведення до них змісту цього наказу вимушений прогул з їх боку начебто продовжується, а заробітна плати у зв'язку із цим за ними фрактично зберігається [10, с. 245]. 3 аналізовано вище можна дійти висновку, що вченими-юристами в контексті зловживання правами у виконавчому процесі ведеться мова про виконавців, стягувачів, боржників. У контексті того, що приписи ст. 6 Конвенції про захист прав людини і основоположних свобод передбачають право на справедливий суд, включаючи і процес виконання рішення, то заслуговують уваги і приписи ст. 17 цієї ж Конвенції - заборона зловживання правами. Щодо наведеного влучно узагальнив О.М. Дроздов: у забороні «зловживання правами» ст. 17 спрямована на забезпечення демократій засобами боротьби з діями та діяльністю, які знищують або неналежним чином обмежують основні права і свободи незалежно від того, чи ці дії або діяльність здійснюються «державою», «групою» або «особою» («Bîrsan проти Румунії» (ріш.), § 68) [11, с. 208]. О.М. Кузнець, фокусно досліджуючи питання зловживання правами в цивільному та виконавчому процесах, резюмує, що у виконавчому провадженні серед суб'єктів, які здатні зловживати своїми правами, можна виділити стягувача, боржника та, опосередковано, державу, яка під час регламентації їхніх прав у законі створює переваги для тих чи інших суб'єктів [5, с. 160]. Як видається, з таким твердженням неможливо однозначно погодитись, адже самі по собі колізії, прогалини та інші недоліки правового регулювання здійснення виконавчого процесу (в тому числі і в контексті прав сторін виконавчого провадження) не створюють зловживання правами - недосконала виконавча процедура це ще не зловживання правами. Зловживання правами у виконавчому процесі неможливе без діянь суб'єктів виконавчого процесу. Хоча в юридичній науці можна зустріти концепт того, що держава є суб'єктом правовідносин, проте автору не доводилось зустрічати наукові розробки, в яких би обґрунтовувалось, що держава є суб'єктом правовідносинувиконавчомупроцесі. Уцьомуєсенсзогляду на те, що «держава діє через когось», наприклад, через органи державної влади. У цьому ракурсі, в контексті зловживань із боку держави у виконавчому процесі, має йтися про суб'єктів виконавчого процесу, наділених владними повноваженнями: 1) виконавці (державні чи приватні); 2) прокурори як представники інтересів держави у виконавчому процесі; 3) працівники поліції; 4) працівники (представники) органу опіки і піклування (презентують державу / місцеве самоврядування - це пов'язано зі стату- 
сом таких органів - див. п. 3 Порядку провадження органами опіки та піклування діяльності, пов'язаної із захистом прав дитини, затвердженого постановою Кабінету Міністрів України від 24 вересня 2008 р. № 866) [12]; суди; інші суб'єкти, наділені владними повноваженнями (адже перелік суб'єктів виконавчого процесу не $€$ вичерпним, оскільки наперед неможливо встановити, з яким суб'єктом доведеться взаємодіяти виконавцю під час здійснення примусового виконання рішень, зокрема залучити для проведення виконавчих дій). Як видається, суть зловживання правами найбільш точно та ілюстративно окреслив Й.О. Покровський: «Можливі випадки, коли особа, яка має право, користується ним не для задоволення яких-небуть своїх інтересів, а з виключною метою спричинити шкоду іншому. Одним із найбільш типових й історично давніх випадків такого роду був випадок будівництва на зло сусіду: я будую на межі своєї ділянки високу стіну з виключною метою позбавити світла вікна вашого будинку. Подібна реалізацію права з метою спричинити шкоду іншому носить назву зловживання правом або шикана [13, с. 113]. Саме через таку призму пропонується розглядати зловживання правами у виконавчому процесі - як реалізацію суб'єктами виконавчого процесу своїх прав, в той час, коли здійснюєтьсяпримусовевиконаннярішення, зєдиною метою - спричинити шкоду іншому суб'єкту (іншим суб'єктам) виконавчого процесу. Відтак можна стверджувати, що будь-який суб'єкт виконавчого процесу може зловживати своїми правами, які в нього наявні як у суб'єкта виконавчого процесу. Тут першочерговою $є$ суть зловживання правом (мета - нашкодити іншому), а не суб'єкт зловживання. Зловживання правами у виконавчому процесі суттєво впливає на хід такого процесу (наприклад, якщо особа звертається до суду з необґрунтованою заявою про заміну вибулої сторони правонаступником, то це буде підставою для зупинення вчинення виконавчих дій), може поставити під сумнів законність початку виконавчого процесу (наприклад, якщо особа, яка зазначена як стягувач у виконавчому документі, пред'являє його до примусового виконання, достеменно знаючи, що рішення, за яким цей виконавчий документ видано, вже виконано), тож суб'єкти виконавчого процесу не повинні допускати у своїх діяннях зловживання правами.

Висновки і пропозиції. Узагальнюючи наведене вище, можна запропонувати розуміти під зловживаннями правами у виконавчому процесі реалізацію суб'єктами виконавчого процесу своїх прав, у той час коли здійснюється примусове виконання рішення, з єдиною метою - спричинити шкоду іншому суб'єкту (іншим суб'єктам) виконавчого процесу. Зловживання правами у виконавчому процесі можливе як у формі дій, так і у формі бездіяльності. Будь-який суб'єкт виконавчого процесу може зловживати своїми правами, які в нього наявні як у суб'єкта виконавчого процесу, це має місце, коли свої права такий суб'єкт реалізує виключно для того, щоб нашкодити іншому суб'єкту (суб'єктам) виконавчого процесу. Перспективними видаються і подальші наукові дослідження сфрери зловживання правами у виконавчому процесі (наприклад, вироблення механізму недопущення таких зловживань).

\section{Список використаної літератури:}

1. Камышанський В.П., Ветер Н.Ю. Злоупотребление правом: понятие, признаки, общая характеристика. Научный журнал КубГАУ. № 112(08). 2015. С. 1-21.

2. Марунич Г.І. Затягування цивільного процесу: сутність, правові наслідки та способи запобігання : дисертація ... кандидата юридичних наук. Спеціальність 12.00 .03 - цивільне право і цивільний процес; сімейне право; міжнародне приватне право. Київ. 2018. 240 с.

3. Курс цивільного процесу : підручник / В.В. Комаров, В.А. Бігун, В.В. Баранкова та ін. ; за ред. В.В. Комарова. Харків : Право, 2011. 1352 с.

4. П'ятницький А.В. Адміністративно-правове забезпечення реалізації заходів примусового виконання судових рішень в Україні : дис. ... кандидата юридичних наук. Спеціальність 12.00.07 - адміністративне право і процес; фінансове право; інформаційне право (081 Право). Суми. 2018. 225 с.

5. Кузнець О.М. Суб'єкти зловживання правами у цивільному та виконавчому процесі : дис. ... кандидата юридичних наук. Спеціальність 12.00.03 - цивільне право і цивільний процес; сімейне право; міжнародне приватне право. Київ. 2016. 225 с.

6. Золотаренко В.В. Реалізація принципу диспозитивності у діях суб'єктів виконавчого провадження. Цивілістична процесуальна думка. 4/2016. C. 38-41.

7. Євтошук Ю.О. Принцип пропорційності як необхідна складова верховенства права : дис. ... кандидата юридичних наук. Спеціальність 12.00.01 - теорія та історія держави і права; історія політичних і правових учень. Київ. 2015. 214 с.

8. Чумак О.О. Адміністративно-правові засади діяльності державної виконавчої служби в 
Україні в умовах реформування органів виконавчої влади : дис. ... доктора юридичних наук. Спеціальність 12.00.07 - адміністративне право і процес; фрінансове право; інформаційне право. Дніпро. 2016. 484 с.

9. Король О.Д. Деякі аспекти зловживання процесуальних прав у виконавчому провадженні. Проблеми теорії і практики виконання рішень судів та інших органів : зб. наук. пр. / за ред. Ю.В. Білоусова. Хмельницький : ФОП Мельник А.А., 2019. С. 103-106.

10.Снідевич О.С. Процедура виконання рішень немайнового характеру, які не можуть бути виконані без участі боржника: сучасний стан та напрямки удосконалення. Проблеми теорії і практики виконання рішень судів та інших органів : зб. наук. пр. / за ред. Ю.В. Білоусова. Хмельницький : ФОП Мельник А.А., 2019. C. 239-246.
11.Дроздов О.М. Реалізація окремих правових позицій Європейського суду з прав людини в контексті розвитку кримінального процесуального законодавства. Захист прав людини: міжнародний та вітчизняний досвід: матеріали I Міжнародної науково-практичної конферениії (16 травня 2019 року). Київ : Національна академія прокуратури України, 2019. С. 207-2011.

12.Порядок провадження органами опіки та піклування діяльності, пов'язаної із захистом прав дитини, затверджений постановою Кабінету Міністрів України від 24 вересня 2008 р. № 866. Електронний ресурс. Верховна Рада України. Законодавство України. URL : https://zakon.rada.gov.ua/laws/show/980_227? find $=1 \&$ text=\%E2\%E8\%EA\%EE\%ED\#w16 13.07.2020.

13.Покровский И.А. Основные проблемы гражданского права. Москва, 1998. 353 с.

\section{Sergiienko N. A. Misuse of rights in executive process}

The article is devoted to problems of misuse of rights in executive process. Basic points of view by the lawyers on the essence and core of misuse of rights in general, misuse of rights in judicial processes, executive process have been explored by the author of article. During scientific exploration, the author have debated with other scientists, especially on the question about possibility to abuse the rights only in the form of active behavior; about essence of abuse the rights, especially in the executive process, as there realization in contradiction to rights and interests of other subjects of this relation. The author of article have grounded that misuse of rights in executive process is possible in either active behavior (activity), or passive behavior (inactivity). The scientific article contains examples of misuse of rights in executive process in inactive manner. The author of article have grounded that the essence of misuse of rights cannot be determined as making the acts by some subjects in contradiction to rights and interests of other subjects of executive process. This is grounded by thesis that this subjects have opposite interests, they realize their rights by their own will. The last is corresponds with the principle of dispositiveness as the one of principles of executive process (see sub.per. 4 par. 1 art. 2 The Law of Ukraine "On executive process"). In the scientific article the author have offered to determine the misuse of rights in executive process as the realization rights by subjects of executive process during the compulsory execution of decision with the only target - to cause losses for other (others) subject (subjects) of executive process. All subjects of executive process can misuse there rights that they have as the subjects of executive process, that concluded in the scientific article. This misuse takes place if the subject, mention above, realizes his $\backslash$ her rights with the only target - to cause losses for other subject (subjects) of executive process. The author of article have mentioned that successive scientific investigations under the theme of misuse of rights in executive process are actual. In compliance with the author's point of view, it is perspective to make the algorithm of prevention misuse of rights in executive process.

Key words: executive process, misuse of subjective rights, subjects of executive process, executor, creditor, debtor. 


\section{ГОСПОДАРСЬКЕ ПРАВО, ГОСПОДАРСЬКО-ПРОЦЕСУАЛЬНЕ ПРАВО}

УДК 346.1

DOI https://doi.org/10.32840/1813-338X-2020.3.8

B. О. Коверзнев

доктор юридичних наук, доцент, старший науковий співробітник Інституту економіко-правових досліджень імені В. К. Мамутова Національної академії наук України

\section{ПРАВОВА ХАРАКТЕРИСТИКА ДЕЯКИХ ЗАСАД ГОСПОДАРСЬКОГО СУДОЧИНСТВА УКРАЇНИ}

У статті досліджено співвідношення категорій «господарське судочинство» $i$ «правосуддя», розкрито правовий зміст дефрініцій "справедливість» $і$ «верховенство права» як основних засад (принципів) господарського судочинства України.

Обгрунтовано, що під господарським судочинством слід розуміти виключно процесуальну діяльність господарських судів, пов'язану з розглядом господарських справ, що має на меті захист прав і законних інтересів учасників господарських відносин.

Доведено, що поняття «правосуддя» має більш широке значення, оскільки не лише відображає процес вирішення спору, а й передбачає ухвалення справедливого судового рішення, яке забезпечує ефективний захист та відновлення порушених прав і законних інтересів учасників господарських відносин. У процесі здійснення правосуддя суддя повинен оцінити чинне законодавство України на предмет його відповідності засадам справедливості та верховенства права, при цьому має можливість відходу від застосування норм законодавства в тому разі, якщо це призведе до ухвалення формально законного, проте несправедливого судового рішення.

Аргументовано, що в контексті здійснення правосуддя під справедливістю слід вважати ефективне відновлення та захист порушених (невизнаних чи оспорюваних) прав, свобод та інтересів учасників господарських відносин, що відбувається в процесі вирішення спору безстороннім і неупередженим судом, на засадах рівності усіх учасників процесу та забезпечення їм однакових можливостей у реалізації процесуальних прав, зокрема: брати участь у судових засіданнях, надавати докази, висловлювати свої міркування та заперечення із проводу правової позиції інших учасників.

Визначено, що до невід'ємних елементів верховенства права належать:

1) дотримання основоположних прав людини, закріплених у Конституції України та міжнародних актах, що є частиною національного законодавства України;

2) відповідність законодавчих актів засадам верховенства права та принципу юридичної визначеності;

3) забезпечення кожному безперешкодного доступу до суду, а також права на незалежний, неупереджений і справедливий суд, створений відповідно до закону;

4) реальне та ефективне виконання ухвалених судових рішень.

Ключові слова: господарське судочинство, правосуддя, справедливість, верховенство право.

Постановка проблеми. Відповідно до частини першої статті 2 Господарського процесуального кодексу України (далі - ГПК Укра- їни) завданням господарського судочинства $€$ справедливе, неупереджене та своєчасне вирішення судом спорів, пов'язаних із здійснен- 
ням господарської діяльності, та інших справ, віднесених до юрисдикції господарського суду, з метою ефективного захисту порушених, невизнаних або оспорюваних прав і законних інтересів фрізичних та юридичних осіб [1].

За приписом частини третьої цієї ж статті до однієї з основних засад (принципів) господарського судочинства належить верховенство права.

Згідно з положеннями статті 11 ГПК України під час розгляду справи господарський суд керується принципом верховенства права; суд розглядає справи відповідно до Конституції України, законів України, міжнародних договорів, згода на обов'язковість яких надана Верховною Радою України; суд застосовує Конвенцію про захист прав людини і основоположних свобод 1950 року і протоколи до неї, згоду на обов'язковість яких надано Верховною Радою України, та практику Європейського суду з прав людини як джерело права.

Таким чином, ГПК України запроваджує розгляд господарських справ на засадах справедливості та верховенства права, при цьому не розкриває правовий зміст цих дефрініцій, що призводить до формування різних підходів у сорері правозастосування та не сприяє єдності судової практики.

Крім того, чинний ГПК України застосовує таку правову категорією як «судочинство», водночас Конституція України, поряд із цією категорію, оперує ще й поняттям «правосуддя» [2, ст. ст. 124, 129], що викликає потребу дослідження їх співвідношення.

Аналіз останніх досліджень і публікацій. Незважаючи на те, що теоретична розробка основних положень господарського права знайшла своє відображення у працях вітчизняних науковців-господарників (А.Г. Бобкової, О.А. Бєляневич, О.М. Вінник, О.П. Віхрова, Р.А. Джабраїлова, Д.В. Задихайла, Г.Л. Знаменського, О.Р. Зельдіної, О.Р. Кібенко., І.В. Лукач, В.К. Мамутова, І.Г. Побірченка, В.В. Поєдинок, О.П. Подцерковного, В.А.Устименка, В.Ю. Уркевича, В.С. Щербини та інших), правова природа наведених вище категорій (справедливість, верховенство права) в контексті здійснення господарськими судами правосуддя не розкривалася, що зумовлює актуальність даного дослідження.

Мета дослідження. Метою цією статті $€$ дослідження співвідношення таких категорій, як «господарське судочинство» $\mathrm{i}$ «правосуддя», а також розкриття правового змісту десрініцій «справедливість» і «верховенство права» як основних засад господарського судочинства України, що має теоретико-прикладне значення.

Виклад основного матеріалу.

Господарське судочинство. Стаття 129 Конституції України встановлює такі засади судочинства, як: рівність усіх учасників судового процесу перед законом і судом; забезпечення доведеності вини; змагальність сторін та свобода в наданні ними суду своїх доказів і в доведенні перед судом їх переконливості; підтримання публічного обвинувачення в суді прокурором; забезпечення обвинуваченому права на захист; гласність судового процесу та його повне фріксування технічними засобами; розумні строки розгляду справи судом; забезпечення права на апеляційний перегляд справи та у визначених законом випадках - на касаційне оскарження судового рішення; обов'язковість судового рішення.

Водночас стаття 2 ГПК України визначає господарське судочинство як розгляд судами господарських справ.

Системний аналіз положень статті 129 Конституції України і статті 2 ГПК України в їх взаємозв'язку дає підстави для висновку, що під господарським судочинством слід розуміти виключно процесуальну діяльність господарських судів, пов'язану з розглядом господарських справ (спорів); метою господарського судочинства $є$ захист прав і законних інтересів суб'єктів господарювання та держави, яка бере участь у господарських відносинах через органи державної влади та органи місцевого самоврядування.

Правосуддя. У статті 124 Конституції України зазначається, що правосуддя здійснюють виключно суди.

Здійснюючи дослідження справедливості як юридичної категорії, С.П. Погрібняк запропонував розглядати правосуддя як процедуру, яка уможливлює поєднання права зі справедливістю [3, с. 14].

За словами Аристотеля (Етика $V, 7)$ «... йти до суду - означає звернутися до справедливості, оскільки суддя бажає бути уособленням справедливості. До того ж люди шукають неупередженого суддю та інколи називають суддів «посередниками», щоб цим визначити, що досягнув справедливого рішення, почнуть триматися середини» [4, с. 414].

Таким чином, у фрілософрії права правосуддя ототожнюється, насамперед, із ухваленням судами справедливого рішення. 
Вказане дозволяє дійти висновку про те, що не кожний розгляд справи є правосуддям, оскільки не кожне судове рішення відповідає критеріям справедливості, навіть у випадку його ухвалення у чіткій відповідності з процесуальним і матеріальним законодавством.

Отже, поняття «правосуддя» $є$ значно ширшим, ніж поняття «судочинство», тому як, якщо здійснення судочинства відображає виключно процесуальну діяльність суду у відповідності до процедурних правил, встановлених процесуальним законодавством, то правосуддям $€$ процес вирішення спору та ухвалення судового рішення, яке повинно відповідати засадам справедливості та забезпечувати ефеективий захист та відновлення порушених прав і законних інтересів фрізичних, юридичних осіб і держави.

Здійснення правосуддя вимагає від суддів дотримання норм матеріального та процесуального права з одночасною оцінкою цих норм на предмет відповідності засадам справедливості та верховенства права, що, в окремих випадках, передбачає можливість відходу судді від застосування норм чинного законодавства, якщо це призведе до ухвалення фрормально законного, але несправедливого судового рішення, та не забезпечить ефективний захист та/або відновлення порушених прав і законних інтересів потерпілої особи.

Мабуть саме з таких позицій виходили розробники змін до Конституції України, що ухвалені Законом від 02.06.2016 № 1401-VIII, якими виключено 3 раніше чинної редакції статті 129 Конституції України таку засаду судочинства, як законність.

Слід зазначити, що справедливість - це передусім фрілософрька категорія. У типології категорія «справедливість» Р.А. Джабраїлов виділяє «зрівняльну справедливість», яка передбачає досягнення максимальної рівності прав і можливостей соціальних суб'єктів, а також «відплатну справедливість», яка поширюється на сферу покарань за правопорушення та $€$ гарантією притягнення до юридичної відповідальності [5, с. 75].

3 античних часів справедливість уособлювалася 3 головною ідеєю права як інституційного механізму реалізації та практичного адміністрування справедливості, яка щоразу підлягає конкретизації [6, с. 366].

У фрілософрії права виділяють об'єктивну (інституційну) і суб'єктивну (особисту) справедливість, а також матеріальну та процедурну справедливість.
Об’єктивною справедливістю є реалізація основних ідей справедливості в певних соціальних інститутах (економіці, освіті, сім'ї тощо); суб'єктивною справедливістю вважається добропорядність людини, яка на добровільній основі виконує вимоги інституційної справедливості; матеріальною справедливістю $є$ втілення ідей справедливості в законодавство, що регулює конкретні правовідносини, а процедурною справедливістю - втілення в норми права ідей, які забезпечують належний і безсторонній розгляд спору судом, а також рівність усіх учасників судового процесу перед законом і судом [7, с. $41 ; 3$, с. 79-84].

Прикладом реалізації об'єктивної справедливості, втіленої в матеріальний закон, $\epsilon$ закріплення в Господарському кодексі України господарювання на засадах: забезпечення економічної багатоманітності та рівного захисту державою усіх суб'єктів господарювання; свободи підприємницької діяльності в межах, визначених законом; вільного руху капіталів, товарів та послуг на території України; обмеження державного регулювання економічних процесів у зв'язку з необхідністю забезпечення соціальної спрямованості економіки, добросовісної конкуренції в підприємництві, екологічного захисту населення, захисту прав споживачів та безпеки суспільства і держави; захисту національного товаровиробника; заборони незаконного втручання органів державної влади та органів місцевого самоврядування, їх посадових осіб у господарські відносини [8, ст. 6].

Прикладом процедурної справедливості $€$ норми статті 129 Конституції України та частини третьої статті 2 ГПК України, які гарантує рівність усіх учасників судового процесу перед законом і судом.

За висловом Ульпіяна, «Justitia est constans et perpetua voluntas jus suum cuique tribuendi» (Справедливістю $€$ непорушне та незмінне прагнення надати кожному, що належить йому по праву) [9, с. 86-88].

3 урахуваннях розглянутих вище підходів до визначення категорії «справедливість» у контексті здійснення правосуддя справедливістю слід вважати ефективне відновлення та/або захист порушених (невизнаних чи оспорюваних) прав, свобод та інтересів особи, що відбувається в процесі вирішення спору безстороннім і неупередженим судом, здійсненим на засадах рівності усіх учасників процесу, та забезпечення їм однакових можливостей у реалізації своїх процесуальних прав. 
Верховенство права. Право - це універсальний регулятор суспільних відносин, за допомогою якого відбувається розв'язання юридичних спорів.

Сьогодні у світі домінують дві основні концепції права: концепція позитивного права (державо-центристська концепція) та концепція природного права (людино-центристська концепція).

Прихильники концепції позитивного права ототожнюють право виключно із законодавством, що санкціоновано державою. Такий підхід до визначення права повністю ігнорує можливі моральні аспекти відносин суб'єктів права та розглядає людину, насамперед, як об'єкт права, поведінка якого підлягає врегулюванню законодавчими нормами без урахування позиції самої людини. Концепція позитивного права не визнає право судді на застосування творчого підходу до вирішення спору, виходячи з конкретних обставин справи.

Концепція позитивного права абсолютизує догматичні та формально-логічні методи правознавства, при цьому виводиться з теорії Ганса Кельзена (1881-1973), яка детально описана в роботі «Чисте Правознавство». Як відправний пункт Ганс Кельзен застосовує неокантіанську теорію права та робить висновок, що право - це нормативне впорядкування людської поведінки за допомогою правової норми, яка є об'єктивно чинною лише тоді, коли людська поведінка, яку вона регулює, фрактично відповідає їй - хоча б до певної міри [10, с. 14, 21].

Відомий юридичний позитивіст XIXст. Джон Остін вважав, що основою права $є$ влада і воля; право - це команда суверена, людини, наказом якої коряться інші люди і яка звичайно не кориться наказам інших; причиною звички коритися здебільшого $є$ влада, яка загрожує санкціями за непослух, а не моральний авторитет суверена [11, с. 13].

Таким чином, прихильники концепції юридичного позитивізму асоціюють право з волею правлячої еліти та не пов'язують із мораллю.

Проте, як вказує М.І. Козюбра, позитивне право працює лише тоді, коли законодавство відповідає потребам громадян і суспільству в цілому, нагромадженим правовим цінностям; коли воно своєчасно оновлюється і не формально-догматично застосовується. Ототожнювати ж його із правом, як це все ще має місце у вітчизняній теорії права, особливо в галузевих науках і в юридичній практиці, некоректно [12, с. 36].
Концепція природного права почала розроблятися ще в часи Стародавньої Греції та Стародавнього Риму такими фрілософрами, як Демокрит, Сократ, Платон, Аристотель, Цицерон та інші.

Основоположною ідеєю природно-правової концепції виступає те, що право виходить від самої людини, а не дарується державою, і має на меті забезпечення людині гідного життя. На відміну від теорії позитивного права, природно-правовий тип праворозуміння розглядає людину, перш за все, як творця права - тобто як суб'єкта, а не як об'єкт. Природне право базується на засадах моральності, справедливості та дієвості, що складають фрілософськоаксіологічне підґрунтя його формування, а не на формальних догмах і правилах [13, с. 86-95].

Якщо зміст правової норми відповідає мотивуючому чиннику особи, можна говорити про моральність норми права. Утім, моральність правової норми $є$ оцінною категорією і залежить від поглядів, які панують у суспільстві в певний період.

Свого часу відомий німецький філософр Едуард Шпрангер (1882-1963) зазначав: «Градація цінностей, яка проводиться колективною мораллю для типових ситуацій, ґрунтується на основі ціннісних суджень, які повинні здійснюватись певною індивідуальною свідомістю, тому як суспільство судить лише у формі суджень його чинів і через них... Відповідно до цього кожна нова моральна оцінка колись повинна обстоюватися індивідуально, і ареною боротьби стає при цьому совість індивіда як члена суспільства. У такій боротьбі беруть участь уже готові колективні оцінки, як вимоги, що містяться у свідомості. У цьому розумінні в ціннісних судженнях колективної моралі зливаються соціально-етичний досвід, вияви волі та переживання норм багатьох генерацій» $[14$, с. 306,328$]$.

Для того щоб певна норма вважалася моральною не обов'язково, щоб таку норму вважали моральною усі без винятку члени суспільства - для цього достатньо визнання моральності норми тим прошарком суспільства, яке визначає генеральний напрямок його розвитку, а також підтримка більшості законослухняного населення країни, що одночасно є й проявом демократії у процесі формування і прийняття норм права [13, с. 89].

Слід відзначити, що збіг правових норм і колективної моралі $\epsilon$ ідеальним станом демократичного суспільства. Більшості країн світу притаманна ситуація, коли за допомогою дер- 
жавного примусу в життя втілюються навіть ті правові норми, які не відповідають соціальній моралі суспільства. У такому випадку правова норма може бути не сприйнятою суспільством.

Згідно з інституційною теорією права, представником якої є Фрідрих Карл Савіньї (17791861), право не має буття само по собі; його сутністю є життя людей, розглянуте з певного боку [15, с. 8, 30]. За цією теорію, право держави не може бути відокремлено від суспільства; воно завжди відображає його ментальність, культуру, звичаї і $\epsilon$ продуктом спільних зусиль цілого народу та його історичного досвіду.

Основні положення концепції природного права закріплені в Конвенції про захист прав людини і основоположних свобод і знайшли своє відображення в Конституції України, зокрема: визнання в Україні найвищою соціальною цінністю людини, її життя і здоров'я, честі і гідності, недоторканності і безпеки; визнання усіх людей рівними у своєї гідності та правах; визнання невідчужуваності, непорушності та невичерпності прав і свобод людини та громадянина; визнання за кожною людиною невід'ємного права на життя, повагу до її гідності; забезпечення кожній людині права на особисту недоторканність і недоторканність житла; гарантування кожному таємниці листування та заборону втручання в особисте і сімейне життя; гарантування кожному права на свободу думки, світогляду і віросповідання, права на свободу об'єднання у політичні партії та громадські організації для здійснення і захисту своїх прав і свобод та задоволення політичних, економічних, соціальних, культурних та інших інтересів [16; 2, ст. ст. 3, 21, 22, 27-32, 34-36].

Очевидно, що в сучасних умовах економічного та соціального розвитку держави положення природного права не здатні врегулювати весь спектр наявних правовідносин, зокрема відносин, що виникають у сфері економічної конкуренції (податкові, фрінансові відносини тощо). Зазначене покладає на державу обов'язок їх врегулювання за допомогою спеціальних законодавчих актів, які відносяться до системи позитивного права. Проте під час ухвалення таких актів держава повинна забезпечити їх відповідність основним критеріям природного права, зокрема моральності, справедливості та дієвості.

Висновки. Проведене дослідження дає підстави для висновку, що господарським судочинством є процесуальна діяльність господарських судів, пов'язана з розглядом справ (господар- ських спорів), і має на меті захист прав і законних інтересів учасників господарських відносин.

Правосуддя відображає процес вирішення спору та ухвалення справедливого судового рішення, яке забезпечує ефективний захист та відновлення порушених прав і законних інтересів учасників господарських відносин. Здійснення правосуддя передбачає творчий підхід судді до застосування чинного законодавства України та його обов'язкову оцінку на предмет відповідності засадам справедливості та верховенства права, з можливістю відходу судді від застосування норм національного законодавства в тому разі, якщо це призведе до ухвалення несправедливого судового рішення.

До невід'ємних елементів верховенства права належать:

1) дотримання основоположних прав людини, закріплених у Конституції України та міжнародних актах, що є частиною національного законодавства України;

2) відповідність законодавчих актів засадам верховенства права та принципу юридичної визначеності;

3) забезпечення кожному безперешкодного доступу до суду, а також права на незалежний, неупереджений і справедливий суд, створений відповідно до закону;

4) реальне та ефективне виконання ухвалених судових рішень.

\section{Список використаної літератури:}

1. Господарський процесуальний кодекс України від 01.11.1991 № 1798-XII (зі змін. та допов.). Відомості Верховної Ради України. 1992. № 6. Ст. 56.

2. Конституція України: Прийнята на п'ятій сесії Верховної Ради України від 28.06.1996 (зі змін. та допов.). Відомості Верховної Ради України. 1996. № 30. Ст. 141.

3. Правосуддя: філософське та теоретичне осмислення : колективна монографія / А.М. Бернюков, В.С. Бігун, Ю.П. Лобода, Б.В. Малишев, С.П. Погребняк, С.П. Рабінович, В.С. Смородинський, О.В. Стовба / (відп. ред. В.С. Бігун). Київ, 2009. 316 с. (Бібліотека Міжнародного часопису «Проблеми фрілософії права»).

4. Нерсесянц В.С. Философия права. Учебник для вузов. Москва : Издательская группа ИНФА-М - НОРМА, 1997. 652 с.

5. Джабраілов Р.А. Принцип справедливості як основа трансформації економіко-правової системи держави. Вісник НАН України. 2017. № 7. С. 74-80.

6. Козеллек Р. Часові пласти. Дослідження з теорії історії: пер. з нім. Київ, 2006. 436 с. 
7. Хефpфе Отфрид. Справедливость: Философское введение / пер. с нем. О.В. Кильдюшова под ред. Т. А. Дмитриева. Москва, 2007. 192 c.

8. Господарський кодекс України від 16.01.2003 № 436-IV (зі змін. та доповн.). Відомості Верховної Ради України. 2003. № 18, № 19-20, № 21-22. Ст. 144.

9. Дигесты Юстиниана: пер. с лат. / отв. ред. Л.Л. Кофанов. Москва, 2002. Т. 1. Книги I-IV.

10.Кельзен Г. Чисте правознавство. 3 додатком: проблема справедливості ; пер. 3 нім. О. Мокровського. Київ : Юніверс, 2004. 496 с.

11.Браєн Бікс. Теорія природного права. Філософрія права; пер. 3 англ. П. Таращука. Київ: Видавництво Соломії Павличко «Основи», 2007. 1254 с.
12.Загальна теорія права : підруч. / за заг. ред. М.І. Козюбри. Київ : Ваіте, 2016. 392 с.

13.Коверзнев В.О. Господарсько-правове забезпечення кооперації в Україні : монографрія / НАН України. Ін-т економіко-правових досліджень. Чернігів : ТОВ «Видавництво Поліграф», 2017. 383 c.

14.Spranger E. Lebensformen. Geistwissenschaftliche Psychologie. Halle: Niemeyer, 1914. S. 416-522 p.

15.F.C.v. Savigny, Vom Beruf unserer Zeit fur Gesetzgebung und Rechtswissenschaft, 1814. 355 p.

16.Конвенція про захист прав людини і основоположних свобод, ратифікована Законом від 17.07.1997 № 475/97-ВР (Редакція від 02.10.2013 р.). Законодавство України. URL : http://zakon1.rada.gov.ua/laws/show/995_004.

Koverznev V. O. Legal characteristics of certain principles of economic judiciary of Ukraine

The article examines the relationship between the categories of "commercial litigation" and "justice", reveals the legal meaning of the definitions of "justice" and "rule of law" as the basic principles of commercial litigation in Ukraine.

It is substantiated that commercial litigation should be understood exclusively as procedural activity of commercial courts related to the consideration of commercial cases, which aims to protect the rights and legitimate interests of participants in economic relations.

It is proved that the concept of "justice" has a broader meaning, as it not only reflects the dispute resolution process, but also provides a fair court decision that provides effective protection and restoration of violated rights and legitimate interests of economic participants. In the administration of justice, a judge must assess the current legislation of Ukraine for its compliance with the principles of justice and the rule of law, and has the opportunity to deviate from the law if it leads to a formally lawful but unfair court decision.

In the context of justice, justice should be considered the effective restoration and protection of violated (unrecognized or disputed) rights, freedoms and interests of participants in economic relations, which occurs in the dispute resolution process by an impartial and impartial court, on the basis of equality of all participants in the exercise of procedural rights, in particular: to participate in court hearings, provide evidence, express their views and objections to the legal position of other participants.

It is determined that the integral elements of the rule of law include:

1) observance of fundamental human rights enshrined in the Constitution of Ukraine and international acts that are part of the national legislation of Ukraine;

2) compliance of legislative acts with the principles of the rule of law and the principle of legal certainty;

3) ensuring everyone unimpeded access to court, as well as the right to an independent, impartial and fair court estaisblhed in accordance with the law;

4) real and effective execution of court decisions.

Key words: commercial litigation, justice, fairness, rule of law. 


\section{ТЕОРЕТИКО-ПРАВОВИЙ АНАЛІЗ ЗАСТОСУВАННЯ МОДЕЛЕЙ МЕДІАЦІЇ В ГОСПОДАРСЬКИХ СПОРАХ}

Стаття присвячена визначенню моделей медіації, які існують у світі та обгрунтуванню найбільш відповідної моделі медіації для спорів, які виникають у бізнес-середовищі.

Автором зроблено висновок, що модель медіації залежить від суб'єктного складу, рівня довіри та виду конфрлікту. Медіація є гнучким, але структурованим процесом, який оперативно адаптується під потреби конкретного конфрлікту. Вибір моделі медіації багато в чому залежить від виду конорлікту, який наразі буде вирішуватися, а також від самих сторін, які конфрліктують. Зазначено, що серед наукової спільноти немає одностайної відповіді щодо кількості та видів моделей медіації. Однак наукові дослідження показують, що для господарських спорів найчастіше застосовуються фрасилітативна, оціночна та трансформативна моделі медіації.

Зроблено висновок, що фрасилітативна модель медіації пропонує вести перемовини на основі інтересів конфрліктуючих сторін замість посилань на права цих сторін, що передбачені законом. Фасилітативна модель медіації в господарських спорах є ефективнішою, якщо справа ще не знаходиться в суді і сторони прагнуть позасудовим методом врегулювати свій конфрлікт. Також автор надає висновок, що медіатор у фрасилітативній моделі медіації також не позбавлений можливості робити попередню юридичну оцінку конфрлікту сторін.

Здійснено дослідження, що оціночна модель також $\epsilon$ ефрективною для господарських спорів, які вже розглядаються судом, адже йдеться про оцінку їхніх позицій. Автором зроблено висновок, що медіатор, який працює в оціночній моделі медіації, звертає свою увагу на основні позиції сторін та визначає за допомогою питань причини суперечки Окрім того, оціночна медіація ставить значно більше вимог до медіатора, адже медіатор має бути фрахівцем в конкретній галузі, аби вміло керувати процесом, ставити питання, надавати рекомендації, вказувати на сильні та слабкі сторони осіб, а також прогнозувати результати судового рішення і оцінювати складові частини конкретної справи.

Автором спростовано доцільність використання трансорормативної моделі медіації в господарських спорах, оскільки ия модель є важливою більше за цивільних спорів, де сторонами конфрлікту виступають фрізичні особи, а не представники бізнес-спільноти. Більше того, в господарських конфрліктах йдеться більше про конфрлікти організацій, які зосереджуються на відстоюванні власних позицій і рідше інтересів.

Дослідження моделі медіації в господарських спорах надало пояснення, що в разі, коли справа знаходиться вже на етапі розгляду в суді, то доцільним є застосування оціночної моделі медіації, а медіатор, у свою чергу, має володіти юридичними знаннями щодо порядку розгляду справи в суді. Якщо сторони вступають у медіацію на етапі позасудового і досудового розгляду та мають за мету з'ясувати власні інтереси в конфліктній ситуації, то в такому випадку медіатору потрібно використовувати фрасилітативну модель медіації.

Ключові слова: медіація, модель, медіатор, господарський процес, господарські спори.

Постановка проблеми. Медіація є одним із найбільш динамічних правових явищ, яке розвивається в різних правових системах. Цінність медіації в тому, що вона дозволяє сторонам швидко і ефрективно вирішувати спори. При цьому поняття ефективності вирішення спорів $є$ достатньо відносним, адже в кожної сто- рони є позиції, інтереси та потреби. Для фрізичних осіб важливим $є$ задоволенням власних потреб у наявних конфліктних ситуації. Однак для конфоліктів, які виникають у бізнес-середовищі, частіше важливим $€$ захист власної позиції. Суб'єктний склад, рівень довіри та вид конфрлікту визначає конкретну модель меді- 
ації, яка $є$ необхідною в певному виді спору та в певній галузі. Окрім того, модель медіації впливає і на критерії вибору медіатора та на його професійні навички

Аналіз останніх досліджень і публікацій. Дослідженням проблеми визначення моделей комерційної медіації займаються Кероль Джі. Браун, Маргарет Дреус, Шарлі Ірвін, Зена Зумета, Грег Руні, Кеннет М. Роберт, Гуохонд (Хелен) Хан, Пітер Д. Хармс, Петра Хіетан-Кунвальд, Кеті Шонк, С. Штраус-Вальс.

Метою статті $\epsilon$ аналіз та подальша теоретична розробка сутності медіації, визначення моделей та принципів медіації в господарських спорах, особливостей фрункціонування медіації в господарських спорах.

Виклад основного матеріалу. На думку ірландського дослідника С. Штраус-Вальс, медіація - один із найбільш перспективних, але недооцінених напрямків альтернативного вирішення спорів. Переваги медіації великі, але відносно невідомі для широкого кола осіб [3]. Фінська дослідниця Петра Хітенен-Кунвальд стверджує, що медіація - це спосіб вирішення суперечок поза законом, але при цьому такий спосіб має власну доктрину, процес та установки. Медіація $є$ соціальною практикою поза правовою системою держави і відповіддю на недоліки правової системи [8, с. 9].

Медіація як структурований процес може здійснюватися за різними моделями. Американські дослідники Гуо Хонг (Хелен) Хан та Пітера Д. Хермс висловлюють думку, що модель медіації залежить від суб'єктного складу, рівня довіри та виду конфлікту [1]. Із цією думкою варто погодитися, адже за своєю правовою природою медіація $є$ гнучким, але структурованим процесом, який оперативно адаптується під потреби конкретного конфрлікту. Вибір моделі медіації багато в чому залежить від виду конфлікту, який наразі буде вирішуватися, а також від самих сторін, які конфрліктують. Не менш важливим для визначення моделі медіації $є$ і стадія вирішення конфрлікту: чи сторони звернулися вже до суду, чи це $є$ наміром сторін вирішити позасудовим способом свій спір?

Серед наукової спільноти немає одностайної відповіді щодо кількості та видів моделей медіації. Австралійська дослідниця Маргарет Древс ствержує, що існує чотири моделі медіації: фрасилітативна, компромісна, оціночна, трансформативна [6]. На думку іншого австралійського дослідника Грег Руні, потрібно виділяти п'ять моделей медіації: фрасилітативна, модель, яка містить собі елементи терапії, трассрормаційна, оціночна та компромісна [10]. Англійський дослідник Кеті Шонк виділяє сім моделей медіації: фрасилітативна, обов'язкова судова, оціночна, трансформативна, медіація-арбітраж, арбітраж-медіація, електронна медіація. Кеті Шонк стверджує, що електронна медіація швидше нагадує традиційну медіацію, але завдяки відеоконференціям учасники тепер можуть легко спілкуватися між собою в режимі реального часу. Ранні результати досліджень свідчать про те, що посилена технологією медіація може бути таким же ефективним способом вирішення спорів, як і традиційні методи [9].

У світі постійно виникають нові гібридні моделі медіації, які комбінують в собі різні способи взаємодії медіатора з конфрліктуючими сторонами. Разом із тим наукові дослідження показують, що для комерційних спорів найчастіше застосовуються фрасилітативна, оціночна та трансформативна моделі медіації.

Фасилітативна модель медіації пропонує вести перемовини на основі інтересів конфліктуючих сторін замість посилань на права цих сторін, що передбачені законом. Американський дослідник Зена Зумета стверджує, що у 1960-1970-х роках фрасилітативна модель медіації була єдиною моделлю посередництва. Цінність цієї моделі медіації полягає в тому, що медіатор відповідає за процес, а сторони - за результат [7, с. 1]. Фасилітативна модель медіації активно розвивалася до моменту появи оціночної моделі. Оціночна медіація бере початок свого розвитку при судах, оскільки вона стала тим механізмом, який дозволяв сторонам на момент звернення до суду оцінити перспективи розгляду своєї справи в суді за допомогою аналізу слабких та сильних сторін. Відповідальність за аналіз слабких та сильних сторін беруть на себе медіатори.

Американський дослідник Кеннет М. Робертс зазначає, що в 1994 та 1996 роках Леонард Ріскін опублікував дві статті, в якій проаналізував переваги оціночної та фасилітативної моделей медіації [5], які на той момент почали активно розвиватися в США. Поява цих двох статей спровокувало дискусію щодо двох моделей медіації. Деякі з дослідників висловлюють припущення, що оціночна модель медіації не має на меті допомагати сторонам знайти рішення, яке їх би задовольняло за результатами наявного конфлікту. Інші ж дослідники стверджують, що навіть для фасилітативної моделі медіації важливим $€$ попередня оцінка конфрлікту. При- 
хильники оціночної моделі медіації стверджують, що ця модель $є$ найбільш ефективною для комерційних спорів, які вже розглядаються судом, адже мова йде про оцінку їхніх позицій. Також значний інтерес оціночної моделі медіації в комерційних спорах зумовлений і специфрікою самої галуззі, адже в комерційній медіації беруть участь юридичні особи, для яких важливим $є$ відстоювання власної правової позиції задля отримання прибутку у майбутньому. Для бізнесу важливим $є$ забезпечення правильності свого позиціювання на ринку, адже від цього залежать їхні фрінансові надходженння.

Оціночна модель медіації, на думку Кеннет М. Робертс, зосереджує свою увагу на правах сторін та оцінює суть вимог кожної із сторін. При цьому оціночна медіація не використовує традиційні змагальні методи. Медіатор, який працює в оціночній моделі медіації, звертає свою увагу на основні позиції сторін та визначає за допомогою питань причини суперечки [5, с. 10]. Однак це зовсім не означає, що в оціночній медіації ігноруються інтереси сторін. Для оціночної медіації важливою $є$ саме оцінка конфрлікту і надання юридичного висновку по конкретному спору. Окрім того, оціночна медіація ставить значно більше вимог до медіатора, адже медіатор має бути фрахівцем у конкретній галузі, аби вміло керувати процесом, ставити питання, надавати рекомендації, вказувати на сильні та слабкі сторони осіб, а також прогнозувати результати судового рішення і оцінювати складові частини конкретної справи.

Оцінка ситуації у процесі медіації дозволяє сторонам подивитися на справу об'єктивніше. Витрати та ризики від судових процесів сторони можуть оцінювати за допомогою своїх слабких і сильних сторін.

Кеннет М. Робертс стверджує, що фрасилітативна модель медіації прагне розширити між сторонами розуміння конфрлікту, досліджує їх інтереси, створює середовище для спільної роботи. Медіатор ставить питання, щоб зрозуміти ситуацію, і спрямовує сторони побачити потенційні результати свого конфлікту [5]. Фасилітативна модель орієнтована на процес. У разі якщо сторонам для подальшого вирішення спору необхідна додаткова інформація, медіатор рекомендує сторонам звертатися до професійних або юридичних консультацій. Фасилітативна модель медіації в комерційних спорах $\epsilon$ ефрективнішою, якщо справа ще не знаходиться в суді і сторони прагнуть позасудовим методом врегулювати свій конфлікт.
На думку американської дослідниці Кероль Дж. Браун, фрасилітативна модель медіації $\epsilon$ найбільш оптимальною моделлю для багатьох цивільних, в тому числі і комерційних спорів. Медіація на основі інтересів - це можливість творчо підійти до вирішення суперечки. Фасилітативна модель медіації допомагає віднайти результат вирішення спорів, який буде задовольняти обидві стороні, більше, ніж будь-яке рішення, що засноване на захисті прав і викладене суддею [4]. Окрім того, медіатор в фрасилітативній моделі медіації також не позбавлений можливості робити попередню юридичну оцінку конфрлікту сторін.

Трансфрормативна модель медіації $є$ найновішою моделлю медіації. Як стверджує Зена Зумета, трансформативна медіація базується на розширенні прав і можливостей кожної із сторін та визначенні потреб, інтересів цінностей кожної із сторін в конфллікті [7]. Польський дослідник Шарлі Ірвін [2] стверджує, що трансформативна модель медіація $є$ ефрективною, коли спочатку необхідно допомогти розібратися людині в собі, а лише потім визнати свою провину. Трансформативна модель медіації $є$ важливою більше за цивільних спорів, де сторонами конфрлікту виступають фрізичні особи, а не представники бізнес-спільноти. Більше того, в комерційних конфліктах йдеться більше про конфллікти організацій, які зосереджуються на відстоюванні власних потреб і рідше інтересів.

Висновки та пропозиції. Медіація є позасудовим способом врегулювання комерційних спорів. Принципами медіації $€$ гнучкість, орієнтація на потреби та інтереси сторін, конфіденційність. Оскільки в основі медіації є принцип гнучкості, то медіація може здійснювати за різними моделями. Серед науковців відсутнє єдине бачення кількості моделей медіації. Більше того, з кожним роком виникає все більша кількість гібридних форм моделей медіації, які можуть поєднувати у собі арбітраж.

Разом із тим науковці висловлюють думки про те, що оціночна та фрасилітативна моделі медіації $€$ найбільш використовуваними моделями медіації в комерційних спорах. Оціночна модель медіація здійснює оцінку конфрлікту з урахуванням слабких та сильних сторін. В оціночній медіації медіатор має бути фахівцем у тій галузі, де виник конфрлікт, адже він має вміло керувати процесом, ставити питання, надавати рекомендації, а також прогнозувати результати судового рішення і оцінювати складові частини конкретної справи. Оцінка ситуації у процесі 
медіації дозволяє сторонам подивитися на справу об'єктивніше. Усе це зумовлює і перелік вимог до медіатора, який має здійснювати оціночну модель медіації. Фасилітативна модель більше орієнтована на процес. Медіатор не надає жодних рекомендацій, а, навпаки, рекомендує сторонам звертатися до професійних або юридичних консультацій, якщо сторонам потрібна додаткова інформація або консультація. Фасилітативна модель медіації в комерційних спорах є ефективнішою, якщо справа ще не знаходиться в суді і сторони прагнуть позасудовим методом врегулювати свій конфлікт.

Перспективи подальших досліджень зможуть надати висновок щодо вимог до медіатора, який буде здійснювати медіацію в господарських спорах, та забезпечити правильний вектор розвитку медіації в господарських спорах.

\section{Список використаної літератури:}

1. Guohong (Helen) Han, P.D. Harms. Team identication, trust, and conflict: a mediation model. URL:https://www.academia.edu/12168786/Team_ identification_trust_and_conflict_a_mediation_ model.

2. Charlie Irvine. "Transformative Mediation: A Critique' assignment for MSc in Conflict Resolution and Mediation Studies, Birkbeck College, University of London (2006). URL : https://www. academia.edu/1976807/_Transformative_Mediation_A_Critique_assignment_for_MSc_in_Conflict_Resolution_and_Mediation_Studies_Birkbeck_College_University_of_London_2006_.

3. S. Strauss-Walsh. Mediation and Therapeutic Jurisprudence. URL : https://www.academia.edu/
29219281/Mediation_and_Therapeutic_Jurisprudence.odt.

4. Carole J. Brown. Facilitative Mediation: The Classic Approach Retains its Appeal. URL : https://gevim.co.il/wp-content/uploads/2014/01/ Facilitative-Mediation.pdf.

5. Kenneth M. Robert. Mediating the EvaluativeFacilitative Debate: Why Both Parties Are Wrong and a Proposal for Settlement. URL : https://pdfs.semanticscholar.org/8351/ 099aa009ca5c86eadd55435267b1bf0a582c.pdf.

6. Margaret Drews. The Four Models of Mediation. URL : http://www.diac.ae/idias/journal/volume3no1/issue1/eng4.pdf.

7. Zena Zumeta. Styles of Mediation: Facilitative, Evaluative, and Transformative Mediation. URL : https://www.rchss.sinica.edu.tw/cibs/law/ 1.\%20Monthly\%20Seminar\%20Since\%202008/ Papers/2009/20090211/Chen-Chieh\%20Ting_ Styles\%20of\%20Mediation_\%20Facilitative, $\% 20$ Evaluative,\%20and\%20Transformative\%20 Mediation.pdf.

8. Petra Hietanen-Kunwald. Mediation and the legal system extracting the legal principles of civil and commercial mediation. URL : https://helda.helsinki.fi/bitstream/handle/10138/243949/mediatio. pdf?sequence=1\&isAllowed=y.

9. Katie Shonk. Types of mediation: choose the type best suited to your conflict. URL : https://www.pon.harvard.edu/daily/mediation/ types-mediation-choose-type-best-suited-conflict/.

10.Greg Rooney. The rise of commercial mediation in Australia-reflections and the challenges ahead. URL : https://www.maynoothuniversity.ie/ sites/default/files/assets/document/5.Rooney $\% 20$ FinDS_0.pdf.

\section{Polishchuk V. V. Theoretical and legal analysis of mediation models application in economic disputes}

The article is dedicated to identifying the mediation models that exist in the world and substantiating the most appropriate mediation model for disputes that arise in business environment.

The author has concluded that a mediation model depends on the parties involved, the level of trust, and the type of conflict. Mediation is a flexible, but structured process quickly adapting to the needs of a particular conflict. Choosing a mediation model largely depends on the type of conflict to be resolved at this point in time as well as on conflicting parties. It is noted that there is no unanimous answer in the academic community regarding the number and types of mediation models. However, the research shows that facilitative, evaluative, and transformative mediation models are most often used for economic disputes.

It is concluded that a facilitative mediation model proposes to negotiate on the basis of interests of conflicting parties instead of referring to the rights of those parties prescribed by law. A facilitative mediation model in economic disputes is more efficient if the case is not yet in court, and the parties seek to resolve their conflict through extrajudicial procedures. Furthermore, the author concludes that a mediator in the facilitative mediation model is not deprived of the opportunity to make a preliminary legal evaluation of the conflict between the parties.

It has been researched that an evaluative mediation model is also efficient for the economic disputes that are already considered in court, as it is referred to evaluation of their opinions. The author has concluded that a mediator working in the evaluative mediation model pays attention to the main 
opinions of the parties and identifies the causes of the dispute through questions. In addition, evaluative mediation puts forward much more requirements to a mediator, as the mediator must be a professional in a particular field in order to be able to manage the process, to ask questions, to give recommendations, to point out the strengths and weaknesses of persons, as well as to predict the results of a court judgment and to evaluate the components of a particular case.

The author has refuted the expediency of using a transformative mediation model in economic disputes, as this model is more important for resolving civil disputes where the parties to the conflict are individuals rather than business community representatives. Moreover, economic conflicts are more referred to conflicts of the entities that focus on defending their opinions and less often - their interests.

Researching a mediation model in economic disputes has explained that if the case is already considered in court, it is expedient to use an evaluative mediation model, and therefore, a mediator must possess legal knowledge of the procedure for considering a case in court. If the parties enter into mediation at the stage of extrajudicial and pre-trial proceedings and aim to ascertain their own interests in a conflict situation, then the mediator should use a facilitative mediation model.

Key words: mediation, model, mediator, economic proceedings, economic disputes. 


\title{
АДМІНІСТРАТИВНЕ ПРАВО I ПРОЦЕС; ФIHAHCOBE ПРABO
}

\author{
УДК [342.9:343.98] (477) \\ DOI https://doi.org/10.32840/1813-338X-2020.3.10
}

O. В. Агапова

кандидат юридичних наук, завідувач відділу міжнародного співробітництва та роботи з іноземцями Харківського науково-дослідного інституту судових експертиз імені заслуженого професора М. С. Бокаріуса Міністерства юстиції України

\section{КЛАСИФІКАЦІЯ НАПРЯМІВ ДІЯЛЬНОСТІ У СФЕРІ ЕКСПЕРТНОГО ЗАБЕЗПЕЧЕННЯ}

У статті виокремлено основні напрями діяльності у сфрері експертного забезпечення в Україні. Проаналізовано сучасні наукові підходи вчених, які присвятили свої наукові праці дослідженню розвитку судово-експертної діяльності в Україні. Це дало змогу зробити висновок щодо відсутності єдиного підходу до класифікації напрямів діяльності у сфері експертного забезпечення. За результатами дослідження основних напрямів діяльності було сфрормульовано низку пропозицій щодо їхньої класифрікації. Першим напрямом діяльності було розглянуто судово-експертну діяльність. Автором було акцентовано, що такий вид діяльності виступає головним елементом, на підставі якого формується сфрера експертного забезпечення. Такі напрями, як добір, професійна підготовка, підвищення кваліфрікації, проведення наукових досліджень, що здійснюються під час навчання в аспірантурі, запропоновано виокремити як напрям освітньо-наукової діяльності. Освітньо-наукова діяльність $\epsilon$ додатковим напрямом і виникає з моменту отримання відповідної ліцензії на здійснення освітньої діяльності. Встановлено, що не всі суб'єкти судово-експертної діяльності здійснюють підготовку кадрів вищої кваліфікації. Аналізуючи випадки експертного забезпечення нотаріату, виконавчого провадження, оціночної й аудиторської діяльності, було встановлено, що їх можна виокремити в окремий напрям діяльності - діяльність із забезпечення експертизою поза межами судового провадження. Наголошено, що такі випадки експертного забезпечення чітко регламентовані у профрільних законах. Обгрунтовано, що міжнародна діяльність у сфрері експертного забезпечення має велике значення для входження судово-експертних установ України до Європейського судово-експертного простору. Визначено перспективні форми міжнародної діяльності у сфері експертного забезпечення.

Ключові слова: сфрера експертного забезпечення, судово-експертна діяльність, освітньо-наукова діяльність, міжнародна діяльність, Європейська мережа судово-експертних установ, діяльність із забезпечення експертизою поза межами судового провадження.

Постановка проблеми. Важко недооцінювати роль і значення сфери експертного забезпечення для нашої держави та суспільства. Той спектр напрямів діяльності, публічних і освітніх послуг, а також інших актуальних завдань, які охоплюються цією сферою, $є$ різноманітним і здатним ефективно реагувати та задовольняти потреби суспільства. Як і будь-яка інша галузь, сфрера експертного забезпечення $€$ динаміч- ною і на їі розвиток впливає багато фракторів, які фрормують ії̈ основні напрями діяльності. На сучасному етапі розвитку експертного забезпечення в Україні вважаємо актуальними наукові дослідження, присвячені аналізу та класифікації наявних напрямів діяльності в цій ссрері.

Метою статті $\epsilon$ формулювання пропозицій щодо класифрікації напрямів діяльності у сфрері експертного забезпечення. 
Аналіз останніх досліджень і публікацій, присвячених розвитку в Україні судово-експертної діяльності, дав змогу виділити наукові здобутки таких учених, як: В. Галунька, Л. Головченко, В. Журавля, О. Клюєва, І. Петрової, Е. Сімакової-Єфремян, О. Угровецького, Г. Стрілець, В. Шепітько, В. Шевчука та інших. Важливо зазначити, що ці та інші вчені зробили вагомий внесок в удосконалення розуміння основ судово-експертної діяльності в Україні, однак питання щодо класифрікації напрямів діяльності у сфері експертного забезпечення досі залишаються малодослідженими.

Виклад основного матеріалу. Очевидно, що трансформаційні процеси, які відбуваються в системі державного управління, впливають на розвиток сфери експертного забезпечення. Предметом активної наукової дискусії стають питання щодо визначення стратегічних напрямів організації експертного забезпечення.

3 метою здійснення більш детального аналізу основних напрямів діяльності, які формують сфреру експертного забезпечення, пропонуємо їх визначити й охарактеризувати (рисунок 1).

Судово-експертна діяльність. Поза сумнівом, саме судово-експертна діяльність виступає головним елементом, на підставі якого формується сфера експертного забезпечення. Задоволення потреб органів та установ, суду й органів досудового розслідування, а також фрізичних і юридичних осіб у забезпеченні їх незалежною, кваліфікованою та об'єктивною експертизою, орієнтованою на максимальне використання досягнень науки й техніки $є$ метою діяльності суб'єктів судово-експертної діяльності. 3 огляду на зазначене наголосимо, що від належного функціонування сфери експертного забезпечення залежить якісне забезпечення судовими експертизами та експертними дослідженнями відповідних суб'єктів.
Повністю підтримуємо позицію Г.О. Стрілець, яка, досліджуючи поняття «судово-експертна діяльність», визначила ії як врегульовану законодавством діяльність судово-експертних установ, що спрямована на проведення незалежних судових експертиз унаслідок об'єктивного, повного і всебічного дослідження з дотриманням сучасних досягнень науки й техніки, організацію роботи судово-експертних установ загалом та їхніх структурних підрозділів, їхнє науково-методичне й інформаційне забезпечення, підбір і підготовку судово-експертних кадрів [1, с. 10].

На переконання Л.М. Головченко, судово-експертну діяльність варто розглядати як діяльність, пов'язану з державним управлінням і науково-методичним забезпеченням у галузі судової експертизи, організацією та проведенням судових експертиз, що спрямовані на забезпечення правосуддя незалежною, кваліфрікованою та об'єктивною експертизою, орієнтованою на максимальне використання досягнень науки та техніки. Досліджуючи основні структурні елементи, вчена акцентує, що судово-експертна діяльність передбачає: 1) проведення судової експертизи; 2) проведення експертних досліджень із метою надання висновків поза межами судочинства; 3) наукові дослідження, пов'язані зі створенням методик проведення судових експертиз (планування, проведення наукових робіт, апробація і впровадження їхніх результатів в експертну практику); 4) науково-методичне й інформаційне забезпечення в галузі судової експертизи; 5) організаційно-управлінське забезпечення в галузі судової експертизи; 6) профрілактику правопорушень засобами судової експертизи; 7) добір, професійну підготовку та підвищення кваліфікації судових експертів [2, с. 7].

Враховуючи наведені підходи до розуміння судово-експертної діяльності, зазначимо, що

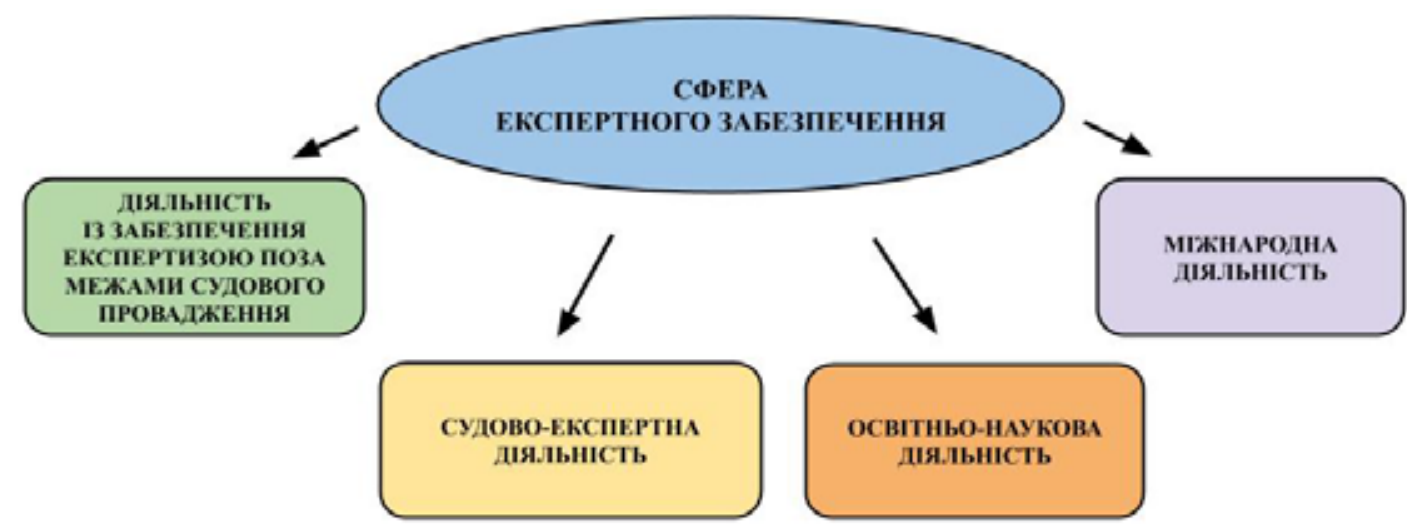

Рис. 1 
окремі напрями, такі як добір, професійна підготовка, підвищення кваліфікації, проведення наукових досліджень, що здійснюються під час навчання в аспірантурі, вважаємо за доцільне розглядати як напрям освітньонаукової діяльності.

Необхідно зазначити, що сферою експертного забезпечення охоплюється також діяльність із забезпечення експертизою поза межами судового провадження (випадки експертного забезпечення нотаріату, виконавчого провадження, оціночної й аудиторської діяльності та інше). Профрільними законами України, зокрема Законом України від 2 червня 2016 р. № 1404-VIII «Про виконавче провадження» [3], Законом України від 26 листопада 1993 р. № 3659-XII «Про Антимонопольний комітет України» [4], Законом України від 2 вересня 1993 р. № 3425-XII «Про нотаріат» [5] регламентується порядок залучення експерта та призначення експертного дослідження.

Освітньо-наукова діяльність у сфері експертного забезпечення. Варто зробити наголос на тому, що суб'єкти судово-експертної діяльності під час задоволення потреб суспільства, окрім судово-експертної діяльності, можуть здійснювати також наукову, науково-технічну, науково-організаційну та освітньо-наукову діяльність (у разі отримання ліцензії на провадження освітньої діяльності).

На прикладі Харківського науково-дослідного інституту судових експертиз ім. засл. проф. М.С. Бокаріуса (далі - ХНДІСЕ) продемонструємо поєднання перелічених вище напрямів діяльності. На відміну від інших державних спеціалізованих установ судових експертиз, що належать до сфрери управління Мін'юсту, лише ХНДІСЕ готує докторів фрілософії та докторів наук за власною освітньо-науковою та науковою програмою в межах предметних напрямів досліджень за спеціальністю 081 Право.

Відповідно до Наказу Міністерства освіти і науки України від 13 червня 2018 р. № 1253- л [6], Наказу Міністерства освіти і науки України від 30 листопада 2018 р. № 2320-л [7] ХНДІСЕ отримано ліцензію на провадження освітньої діяльності на третьому (освітньо-науковому) та науковому рівнях вищої освіти з метою здобуття ступеня вищої освіти доктора філософрії та доктора наук громадянами України, іноземцями та особами без громадянства відповідно. $\mathrm{He}$ менш важливою обставиною, яку варто зазначити, $\epsilon$ те, що згідно з Наказом Міністерства освіти і науки України від 7 листопада
2018 р. № 1218 [8] у ХНДІСЕ діє спеціалізована вчена рада $з$ правом прийняття до розгляду та проведення захисту дисертацій на здобуття наукового ступеня кандидата юридичних наук.

Водночас Наказом Міністерства освіти і науки України від 17 квітня 2019 р. № 334-л ХНДІСЕ видано ліцензію на провадження освітньої діяльності у сфрері післядипломної освіти для осіб із вищою освітою (підвищення кваліфрікації) за спеціальністю 081 Право, за програмою підготовки: «Теоретичні, організаційні і процесуальні питання судової експертизи» [9].

Наголосимо, що до моменту отримання ХНДІСЕ ліцензії на провадження освітньої діяльності у сорері післядипломної освіти, відповідно до ч. 1 розділу IV Наказу Мін'юсту від 3 березня 2015 р. № 301/5 «Про затвердження Положення про експертно-кваліфікаційні комісії та атестацію судових експертів», підготовку (стажування) фахівців, які мали намір отримати та/або підтвердити кваліфікацію судового експерта і які не були працівниками державних спеціалізованих установ, здійснював лише Інститут права та післядипломної освіти Мін'юсту [10].

Незважаючи на те, що освітній напрям діяльності суб'єктів судово-експертної діяльності ще перебуває на етапі становлення, не виникає жодних сумнівів щодо його потужного впливу на розвиток сфрери експертного забезпечення.

Міжнародна діяльність у сфері експертного забезпечення. Двостороннє міжнародне співробітництво з судово-експертними, науковими установами, а також закладами вищої освіти, участь у міжнародних проєктах, акредитація лабораторій державних спеціалізованих установ, запрошення на навчання і стажування іноземних громадян, співробітництво з Європейською мережею судово-експертних установ (European Network of Forensic Science Institutes (ENSI)) - $€$ основними формами міжнародної діяльності у сфрері експертного забезпечення.

Відповідно до ст. 24 Закону України від 25 лютого 1994 р. № 4038-XII «Про судову експертизу» державні спеціалізовані установи, що виконують судові експертизи, користуються правом встановлювати міжнародні наукові зв'язки з установами судових експертиз, криміналістики тощо інших держав, проводити спільні наукові конференції, симпозіуми, семінари, обмінюватися стажистами, науковою інформацією й друкованими виданнями та здійснювати спільні видання в галузі судової експертизи та криміналістики [11]. 
Не викликає сумніву, що закріплене за суб'єктами судово-експертної діяльності право безпосередньо сприяє розвитку міжнародного співробітництва.

Ініціатива Європейського Союзу (далі $€ C)$ щодо створення єдиного Європейського простору Вищої освіти (European Higher Education Area) та Європейського дослідницького простору (European Research Area) (далі - ERA) впливає на механізми забезпечення провадження освітньо-наукової діяльності суб'єктами наукової та науково-технічної діяльності. Зокрема, за визначенням, наведеним у Законі України від 26 листопада 2015 р. № 848-VIII «Про наукову і науково-технічну діяльність», ERA - це система програм і політичних інструментів, що об'єднує інституційне середовище досліджень і розробок держав-учасниць $€ С$ та асоційованих членів із метою розвитку міжнародного науково-технічного співробітництва, вільного трансферу знань, мобільності дослідників [12].

Вважаємо за необхідне також зазначити, що відповідно до ст. 66 Закону України «Про наукову і науково-технічну діяльність» держава забезпечує інтеграцію національного дослідницького простору до ERA шляхом реалізації його пріоритетів, зокрема: 1) підвищення ефективності національної дослідницької системи; 2) оптимізації міжнародної співпраці задля розв'язання глобальних викликів, що стоять перед людством; 3) забезпечення участі у рамкових і спільних міжнародних програмах $€ C$; 4) створення сприятливих умов для мобільності вчених; 5) повноцінного обміну, передання та доступу до наукових знань та інше [13].

Враховуючи важливість міжнародного співробітництва й інтеграцію вітчизняних закладів освіти та наукових установ до ERA, суб'єкти судово-експертної діяльності активно укладають двосторонні договори про наукове співробітництво із закладами освіти та науковими установами іноземних країн, проводять спільні дослідження, конференції, реалізують право на академічну мобільність тощо.

Участь у двосторонніх проєктах міжнародного співробітництва $€$ ще одним пріоритетним напрямом діяльності державних спеціалізованих установ, що сприяє входженню України до ERA. Серед міжнародних проєктів можемо виокремити Рамкову програму ЄС з досліджень та інновацій «Горизонт 2020», Програму наукових досліджень і навчання «Євратом», Міжнародну європейську інноваційну науково-тех- нічну програму «EUREKA», програму HATO «Наука заради миру» [14], «Horizon Europe» (2021-2027) [15] та інші.

Акцентуємо, що міжнародні проєкти дають змогу суб'єктам судово-експертної діяльності отримати державну фрінансову підтримку (грант) для проведення конкретних фрундаментальних і (або) прикладних наукових досліджень, налагодити співробітництво між установами профільного спрямування та підвищити престиж і авторитет установи.

Принагідно зазначимо, що на виконання ст. 24 Закону України «Про судову експертизу» вітчизняні установи судових експертиз також налагоджують співробітництво з суб'єктами судово-експертної діяльності іноземних країн із метою обміну досвідом у питаннях проведення судових експертиз та експертних досліджень.

За влучним зауваженням Н.І. Клименко, національна судова експертиза не може існувати ізольовано, тобто тільки в межах окремої держави, оскільки вона активно не виконуватиме свої функції забезпечення правоохоронної діяльності поза інтеграцією з міжнародною спільнотою. Тому необхідне міжнародне співробітництво експертних установ із метою обміну досвідом, врахування сучасних досягнень науки і техніки, виключення дублювання науково-методичного забезпечення регіонального розподілу завдань між судово-експертними установами, створення профрільних експертних напрямів [16, с. 131].

У напрямі міжнародної діяльності судово-експертних установ важливу роль відіграє Європейська мережа судово-експертних установ (European Network of Forensic Science Institutes (далі - ENSI)).

Сьогодні членами ENFSI є 72 експертні установи. Це найбільша у світі асоціація судово-експертних установ, що отримала міжнародне визнання [17]. У складі ENFSI фрункціонує 17 Експертних робочих груп (Expert Working Groups), які ще називають "рушійною силою» асоціації, адже учасники мають високу кваліфрікацію та досвід в експертній сфрері. Для судових експертів участь у роботі Експертних робочих груп ENFSI дає змогу вільно обмінюватись інформацією за відповідними напрямами експертних досліджень, запозичувати підходи до проведення експертиз, брати участь у розробленні Best Practice Manual (Довідників передових практик), а також відвідувати щорічні зустрічі.

У напрямі дотримання міжнародних стандартів лабораторії державних спеціалізованих установ проходять акредитацію у Національному 
агентстві з акредитації України. На виконання Закону України від 17 травня 2001 р. № 2407-III «Про акредитацію органів з оцінки відповідності» у сфрері експертного забезпечення проводиться акредитація за такими напрямами, як: ДСТУ EN ISO/IEC 17020:2014 «Оцінка відповідності. Вимоги до роботи різних типів органів 3 інспектування» та ДСТУ ISO/IEC 17025:2017 «Загальні вимоги до компетентності випробувальних та калібрувальних лабораторій» та інші [18]. Отримані атестати засвідчують компетентність лабораторій під час проведення досліджень і високу якість їх виконання на вітчизняному та міжнародному рівнях.

Варто зазначити, що інтеграційні процеси в судово-експертній діяльності сприяють гармонізації та вдосконаленню експертного національного законодавства, розвитку теоретичних основ експертних досліджень, виробленню єдиних методичних рекомендацій 3 їхнього проведення, вдосконаленню експертної діяльності, підвищенню професійної майстерності працівників судово-експертних установ, міжнародному визнанню національних експертних висновків [19, с. 240].

Висновки. У процесі дослідження основних напрямів діяльності, що охоплюються сферою експертного забезпечення, було вироблено пропозиції щодо їхньої класифрікації. Зокрема, до основних напрямів діяльності у сфрері експертного забезпечення правосуддя було віднесено такі: 1) судово-експертну діяльність; 2) діяльність із забезпечення судовою експертизою поза межами судового провадження; 3) освітньо-наукову діяльність; 4) міжнародну діяльність.

Підсумовуючи результати проведеного дослідження, зазначимо, що сфера експертного забезпечення - це окрема сфера життєдіяльності держави, в якій виникають суспільні відносини, що складаються як у процесі експертної, судово-експертної діяльності (основний вид діяльності), так і під час освітньо-наукової, міжнародної та інших напрямів діяльності (додаткові напрями діяльності), які безпосередньо впливають на її формування та розвиток.

\section{Список використаної літератури:}

1. Стрілець Г.О. Генезис системи судово-експертних установ в Україні та напрямки їх діяльності : автореф. дис. ... канд. юрид. наук : спец. 12.00.09. «Кримінальний процес та криміналістика; судова експертиза; оперативно-розшукова діяльність». Київ, 2009. 19 с.
2. Головченко Л.М. Про необхідність вдосконалення законодавства про судово-експертну діяльність в Україні. Криминалистика и судебная экспертиза. 2013. Вып. 58 (1). С. 5-12. URL: http://nbuv.gov.ua/UJRN/krise_2013_58(1)_3.

3. Про виконавче провадження : Закон України від 2 червня 2016 р. № 1404-VIII. Відомості Верховної Ради України. 2016. № 30. Ст. 542.

4. Про Антимонопольний комітет України : Закон України від 26 листопада 1993 р. № 3659-XII. Відомості Верховної Ради України. 1993. № 50. Ст. 472.

5. Про нотаріат : Закон України від 2 вересня 1993 р. № 3425-XII. Відомості Верховної Ради України. 1993. № 39. Ст. 383.

6. Про ліцензування освітньої діяльності : Наказ Міністерства освіти і науки України від 13 червня 2018 р. № 1253- л.

7. Про ліцензування освітньої діяльності : Наказ Міністерства освіти і науки України від 30 листопада 2018 р. № 2320-л.

8. Про затвердження рішень Атестаційної колегії Міністерства освіти і науки України щодо діяльності спеціалізованих вчених рад : Наказ Міністерства освіти і науки України від 23 жовтня 2018 p. № 1218.

9. Про ліцензування освітньої діяльності : Наказ Міністерства освіти і науки України від 17 квітня 2019 р. № 334-л.

10.Положення про експертно-кваліфрікаційні комісії та атестацію судових експертів : Наказ Міністерства юстиції України від 3 березня 2015 р. № 301/5. Офріційний вісник України. 2015. № 17. Ст. 468.

11.Про судову експертизу : Закон України від 25 лютого 1994 р. № 4038-XII. Відомості Верховної Ради України. 1994. № 28. Ст. 232.

12.Про наукову і науково-технічну діяльність : Закон України від 26 листопада 2015 р. № 848-VII. Відомості Верховної Ради України. 2016. № 3. Ст. 25.

13.Про наукову і науково-технічну діяльність : Закон України від 26 листопада 2015 р. № 848-VII. Відомості Верховної Ради України. 2016. № 3. Ст. 25.

14.Міжнародні наукові проєкти. Офіційний сайт Міністерства освіти і науки України. URL: https://mon.gov.ua/ua/tag/mizhnarodni-naukoviproekti.

15.Україна має амбіції 2021-го стати асоційованим членом «Horizon Europe». Офріційний сайт Міністерства освіти і науки України. URL: https://mon.gov.ua/ua/news/ukrayina-mayeambiciyi-2021-go-stati-asocijovanim-chlenomhorizon-europe-do-kincya-roku-mi-podamozayavku-zastupnik-ministra-maksim-striha.

16.Клименко Н.І., Купрієвич О.А. Міжнародне співробітництво судово-експертних установ. 
Вісник кримінального судочинства. 2015. № 4. C. $130-134$.

17.ENFSI: 72 members in 39 countries. Офріційний caŭm European Network of Forensic Science Institutes(ENFSI).URL:http://enfsi.eu/about-enfsi/ members.

18.Про акредитацію органів з оцінки відповідності : Закон України від 17 травня 2001 р.
№ 2407-III. Відомості Верховної Ради України. 2001. № 32. Ст. 170.

19. Линник О.В., Омельчук Л.В. Актуальність вступу України до Міжнародних судово-експертних мереж. Міжнародний юридичний вісник: актуальні проблеми сучасності (теорія та практика). Вип. 2-3 (6-7). 2017. C. 236-241.

\section{Agapova O. V. Classification of directions of activities in the sphere of expert ensuring of justice}

The article focuses on the main directions of activities in the sphere of expert ensuring in Ukraine. The modern scientific approaches of scientists have been analyzed, who devoted their scientific works to investigation of the development of forensic activities in Ukraine. It allowed concluding about the absence of the unique approach to classification of directions of activities in the sphere of expert ensuring. The range of the proposals about their classification has been formulated according to the results of conducted research of the main directions of the activities. Forensic activities are considered as the first direction of activities. It has been emphasized by the author that such type of activities is the key element by which the sphere of expert ensuring is being formed, professional training. It was proposed to single out as a direction of educational and scientific activities such directions as selection, advanced training, conducting research carried out during postgraduate studies. Educational and scientific activities are additional direction and appear from the moment of getting appropriate license for implementation of educational activities. It has been established that not all subjects of forensic activities implements the preparations of highly qualified specialists. When analyzing the cases of expert support of notaries, enforcement proceedings, evaluation and audit activities, it was found that they can be separated into a separate direction of activities activities to provide expertise beyond the court proceedings. It is noted that such cases of expert ensuring are clearly regulated in the relevant laws. It has been proved that international activities in the sphere of expert ensuring has a prominent place for entry of Ukrainian forensic institutions into European forensic science area. The promising forms of the international activities, in the sphere of expert ensuring, were determined.

Key words: sphere of expert ensuring of justice, forensic activities, educational and scientific activities, international activities, activities by providing expertise beyond the judicial process. 


\section{УДК 342.95}

DOI https://doi.org/10.32840/1813-338X-2020.3.11

\section{М. Є. Александров}

кандидат юридичних наук, старший науковий співробітник відділу розроблення

та вдосконалення форми одягу Державного науково-дослідного інституту Міністерства внутрішніх справ України

\section{АДМІНІСТРАТИВНО-ПРАВОВІ ЗАСАДИ ФУНКЦІОНУВАННЯ БАЗИ ДАНИХ НЕБЕЗПЕЧНОЇ ПРОДУКЦІЇ UVАGА.GOV.UА»}

У статті досліджено адміністративно-правові засади фрункціонування бази даних небезпечної продукції "UVAGA.GOV.UA». Зазначена база даних фрункціонує в мережі Інтернет із середини 2019 року. На вебсайті "UVAGA.GOV.UA» розміщено інформацію щодо виявленої на ринку небезпечної нехарчової продукції. На сайті також надано інформацію для споживачів, представників бізнесу та посадових осіб органів державного ринкового нагляду щодо порядку здійснення ринкового нагляду та заходів щодо запобігання реалізації небезпечної продукції.

Автор ставить за мету визначити адміністративно-правові засади фрункціонування бази даних небезпечної продукції «UVAGA.GOV.UA». Для досягнення поставленої мети автором здійснено аналіз тлумачень терміна «адміністративно-правові засади», на підставі якого автор визначає адміністративно-правові засади як встановлені адміністративно-правовими нормами підстави фрункціонування системи. Далі автор визначає, на підставі яких нормативно-правових актів фрункціонує база даних небезпечної продукції, які органи відповідальні за ї фрормування, як фрормуються повідомлення про небезпечну продукцію $і$, власне, з якою метою функціонує база даних «UVAGA.GOV.UA».

Формування поняття адміністративно-правових засад здійснювалося за допомогою методу аналізу й індуктивного методу. Визначення підстав, принципів, порядку та мети фрункціонування бази даних "UVAGA.GOV.UA» здійснювалося порівняльно-правовим методом і методом аналізу нормативно-правових актів.

У висновках автор зазначає, що адміністративно-правовими засадами функціонування бази даних небезпечної продукції «UVAGA.GOV.UA» $є$ норми чинного законодавства України. Зазначена система фрактично є публічною версією системи оперативного взаємного сповіщення про продукцію, що становить серйозний ризик, і створена з метою інфрормування громадськості про виявлену на ринку небезпечну нехарчову продукцію. Створення та фрункціонування бази даних «UVAGA.GOV.UA» сприяє забезпеченню безпеки споживачів, запобігаючи випадкам використання продукиії, що становить ризики для життя та здоров'я людей.

Ключові слова: адміністративно-правові засади, база даних, безпечність продукції, небезпечна продукція, державний ринковий нагляд.

Постановка проблеми. 3 липня 2019 року в Україні працює база даних небезпечної продукції "UVAGA.GOV.UA» [1]. Зазначена база утворена Міністерством розвитку економіки, торгівлі та сільського господарства України (далі - Мінекономіки) та $€$ аналогом європейської системи сповіщення про небезпечні товари непродовольчої групи Safety Gate. Утворення бази "UVAGA.GOV.UA» $\epsilon$ вагомим кроком на шляху до забезпечення безпеки споживачів непродовольчих товарів. Враховуючи важливість цього кроку, з'ясуємо адміністративно-правові засади функціонування бази небезпечних товарів «UVAGA.GOV.UA».
Аналіз останніх досліджень і публікацій. Адміністративно-правові засади у сфрерах забезпечення якості та безпечності продукції досліджували у своїх працях Л. Лосюк, В. Брулевич, С. Віннік, О. Остапенко, А. Скоренька та інші. Дослідженню адміністративно-правових засад державного контролю господарської діяльності, зокрема безпечності продукції, присвячено роботи І. Орехової та Л. Гайдук. Державний нагляд за безпечністю нехарчової продукції був об'єктом досліджень Л. Віткіна, Д. Луценка та К. Опанасенка. Однак питання функціонування систем сповіщення про продукцію, що становить серйозний ризик, 
у працях зазначених науковців фрактично не розглядалися. Тим більше, недослідженою сьогодні $\epsilon$ тема фрункціонування власне бази даних небезпечних товарів.

Метою статті $\epsilon$ визначення адміністративно-правових засад функціонування бази небезпечної продукції «UVAGA.GOV.UA». Для досягнення поставленої мети пропонується виконати такі завдання:

- з'ясувати сутність поняття «адміністративно-правові засади»;

- на підставі проведеного аналізу визначити адміністративно-правові засади функціонування бази даних небезпечної продукції «UVAGA.GOV.UA»;

- визначити, якими нормативно-правовими актами регулюється створення та функціонування зазначеної системи;

- з'ясувати підстави, якими визначено порядок формування бази даних небезпечної продукції та органи, відповідальні за фоомування бази;

- визначити кінцеву мету утворення та функціонування бази даних небезпечної продукції «UVAGA.GOV.UA».

Виклад основного матеріалу. Перш за все необхідно з'ясувати сутність поняття «адміністративно-правові засади». С. Любимова, досліджуючи адміністративно-правові засади діяльності приватних підприємств, пише, що адміністративно-правові засади $€$ засобом визначення (закріплення) правових параметрів (підстав, меж, способів) діяльності приватного підприємства [2, с. 211]. Із думкою С. Любимової погоджується також С. Бандурка, який зазначає, що за своєю сутністю адміністративно-правові засади втілюються у відповідних правових нормах, які визначають правове становище приватних підприємств [3, с. 82]. Однак, враховуючи думку зазначених науковців, треба зауважити, що поняття адміністративно-правових засад розглядалося ними в контексті діяльності суб'єктів адміністративно-правових відносин. База даних «UVAGA.GOV.UA» $є$ масивом інформації, а отже, не може бути суб'єктом адміністративно-правових відносин. Утім, вважаємо, що щонайменше одна із складових наданих тлумачень адміністративно-правових засад - правові підстави - може бути визначена в контексті нашого дослідження.

У дослідженні проблем адміністративно-правових засад розвитку державного управління Н. Панова надає таким засадам визначення сукупності адміністративно-правових норм, які визначають основні цінності, принципи, завдання, фрорми та методи розвитку нормотворчої та розпорядчої діяльності органів виконавчої влади $[4$, с. 9]. М. Легенький розглядає адміністративно-правові засади як сукупність «основних методологічних характеристик і принципів регулювання суспільних відносин в окресленій сфері, яка встановлюється нормами адміністративного права та передбачає категоріальне, нормативно-правове й організаційно-управлінське забезпечення» [5, с. 27]. Аналізуючи наведені вище тлумачення, можна дійти висновку, що адміністративно-правові засади взаємопов'язані з нормами адміністративного-права, якими встановлюються ті чи інші принципи діяльності чи функціонування певних сорер суспільних відносин, органів, систем тощо. Тому визначимо адміністративно-правові засади функціонування бази даних небезпечної продукції «UVAGA.GOV.UA» як встановлені адміністративно-правовими нормами підстави функціонування такої системи. Зважаючи на це твердження, визначимо основні питання, які надають можливість розкрити підстави функціонування бази даних «UVAGA.GOV.UA»: якими нормативно-правовими актами врегульовано створення цієї системи, які органи державної влади відповідальні за ії̈ формування, яка продукція вноситься до бази даних, як формуються зміст і структура повідомлень про небезпечну продукцію, з якою метою створено цю систему.

База даних "UVAGA.GOV.UA» утворена Мінекономіки, про що зазначено на головній сторінці відповідного вебсайту [6]. Створення сайту бази даних небезпечної нехарчової продукції регулюється нормою Закону України «Про загальну безпечність нехарчової продукції», у якій зазначено, що центральний орган виконавчої влади, що реалізує державну політику у ссрері економічного розвитку (яким є Мінекономіки), забезпечує безоплатний доступ громадськості через мережу Інтернет до відомостей, які містяться в системі оперативного взаємного сповіщення про продукцію, що становить серйозний ризик [7]. Повідомлення до бази даних "UVAGA.GOV.UA» вносяться органами державного ринкового нагляду, перелік яких зазначено на відповідній сторінці вебсайту [8]. Відповідно до ст. 35 Закону України «Про державний ринковий нагляд і контроль нехарчової продукції» органи ринкового нагляду вживають заходів щодо своєчасного попередження споживачів (користувачів) про виявлену цими органами небезпеку, що становить відповідна продукція [9]. Інформація про небез- 
печну продукцію відповідно до норм зазначеного Закону має поширюватись у засобах масової інформації та через мережу Інтернет. Також Законом визначено, що оприлюднення відомостей, внесених до системи оперативного взаємного сповіщення про продукцію, що становить серйозний ризик, здійснюється в обсязі та порядку, визначених Законом України «Про загальну безпечність нехарчової продукції» [9]. Отже, база даних "UVAGA.GOV.UA» фактично $€$ публічною версією системи оперативного взаємного сповіщення про продукцію, що становить серйозний ризик.

Утворення та функціонування системи оперативного взаємного сповіщення про продукцію, що становить серйозний ризик, визначено ст. 13 Закону України «Про загальну безпечність нехарчової продукції» [7]. Відповідно до ч. 1 ст. 13 зазначеного Закону система оперативного взаємного сповіщення про продукцію, що становить серйозний ризик, утворюється з метою інформування громадськості та обміну між органами виконавчої влади [7]. Порядок функціонування системи оперативного взаємного сповіщення про продукцію, що становить серйозний ризик (далі - Порядок функціонування), затверджено у 2011 році відповідною постановою Кабінету Міністрів України [10].

3'ясуємо, яка саме продукція потрапляє до бази даних «UVAGA.GOV.UA». Поняття небезпечної нехарчової продукції визначено у ст. 1 Закону України «Про загальну безпечність нехарчової продукції» як «будь-яка продукція, яка не відповідає визначенню терміна «безпечна нехарчова продукція» [7]. Водночас безпечна нехарчова продукція - будь-яка продукція, яка за звичайних або обґрунтовано передбачуваних умов використання (зокрема, щодо строку служби та за потреби введення в експлуатацію вимог щодо встановлення і технічного обслуговування) не становить жодного ризику чи становить лише мінімальні ризики, зумовлені використанням такої продукції, які вважаються прийнятними і не створюють загрози суспільним інтересам, з урахуванням: характеристик продукції, зокрема її складу, упаковки, вимог щодо встановлення і технічного обслуговування; впливу продукції на іншу продукцію, якщо вона буде використовуватися разом із нею; попереджень, що містяться на етикетці продукції, в інструкції з її використання та знищення, а також в іншій інформації щодо продукції; застережень щодо споживання чи використання продукції певними категоріями населення (дітьми, вагітними жінками, людьми похилого віку тощо) [7]. Отже, до бази даних «UVAGA.GOV.UA» має заноситись продукція, яка становить ризики суспільним інтересам з урахуванням характеристик продукції, її впливу на іншу продукцію, попереджень і застережень.

Варто зазначити, що на головній сторінці вебсайту бази даних «UVAGA.GOV.UA», на якій надано інформацію щодо виявленої на ринку небезпечної продукції, присутні такі категорії продукції, як медичні вироби, піротехнічні вироби тощо [6]. На медичні та піротехнічні вироби в Україні затверджено відповідні технічні регламенти [11; 12]. Водночас дія Закону України «Про загальну безпечність нехарчової продукції» поширюється лише на продукцію, стосовно якої технічними регламентами не встановлено спеціальні вимоги щодо забезпечення її безпечності [7]. Отже, окреслити продукцію, яка вноситься до бази даних «UVAGA. GOV.UA», можна як продукцію, що не відповідає вимогам технічних регламентів щодо безпечності, а також загальним вимогам щодо безпечності нехарчової продукції.

Розглянемо форму повідомлень про продукцію, розміщену на сайті бази даних «UVAGA. GOV.UA» та з'ясуємо, чи відповідає ця форма встановленим законодавством вимогам. На сторінці «Дитячі товари» на момент звернення (14 липня 2019 р.) розміщено два зразки продукції, щодо яких подано таку інформацію: 1) рівень загрози; 2) номер і дата оповіщення; 3) вид продукції; 4) найменування продукту; 5) марка; 6) тип/номер моделі; 7) опис продукції та упаковки; 8) країна походження; 9) контактні дані виробника; 10) тип і характер ризику; 11) вжиті заходи; 12) тривалість заходів. Для кожного з товарів також наведено його фотографії [13]. Відповідно до Закону України «Про загальну безпечність нехарчової продукції» повідомлення про продукцію, що становить серйозний ризик, має містити: 1) відомості, які дають змогу ідентифікувати відповідну продукцію; 2) опис ризику, який становить продукція, результат експертизи (випробування) зразків такої продукції; 3) інформацію про характер і тривалість заходів, ужитих для запобігання ризику (якщо такі заходи вживалися), зокрема заходів, ужитих виробниками та/або розповсюджувачами за власною ініціативою; 4) інформацію про походження та ланцюги постачання відповідної продукції на ринку України; 5) інші відомості, передбачені правилами подання таких повідомлень до системи оперативного 
взаємного сповіщення про продукцію, що становить серйозний ризик [7]. Натомість у Порядку функціонування визначено більш повний перелік пунктів, що має містити повідомлення про небезпечну продукцію: 1) найменування органу, який подав повідомлення; 2) дату подання та обліковий номер повідомлення; 3) відомості, які дають змогу ідентифікувати відповідну продукцію; 4) фоотограффії товару в ракурсах; 5) опис ризику, який становить продукція, і результати експертизи (випробування) ії̈ зразків; 6) інфрормацію про характер і тривалість заходів, ужитих для запобігання такому ризику (якщо такі заходи вживалися), зокрема виробниками та/або розповсюджувачами за власною ініціативою; 7) відомості про походження та ланцюги постачання відповідної продукції в Україні; 8) додаткову інформацію, яка дає змогу ідентифрікувати зазначену продукцію; 9) посаду, прізвище та ініціали особи, яка підписала повідомлення [10]. Якщо порівняти схему повідомлень, розміщених на сайті «UVAGA.GOV.UA», то можемо побачити, що вона цілком відповідає Закону України «Про загальну безпечність нехарчової продукції». На сайті відсутня інфрормація щодо найменування органу, який подав повідомлення, та про посаду, прізвище й ініціали особи, яка підписала повідомлення. Зазначимо, що відсутність цих відомостей не суперечить Порядку функціонування, адже відповідно до п. 7 зазначеного Порядку громадськість має доступ до відомостей щодо безпечності продукції, вжитих щодо неї заходів та інформації, яка дає змогу ідентифікувати продукцію [10].

Водночас необхідно зазначити, що інфоормація про небезпечну продукцію, представлена на сайті, у деяких випадках представлена не в повному обсязі. Наприклад, у категорії «Медичні вироби» до деяких виявлених небезпечних товарів відсутні їхні фотографії, а також не зазначено тип і характер ризику [14]. Отже, можна рекомендувати адміністраторам сайту перевіряти обсяг і характер інформації, розміщеної на сайті, та у разі відсутності необхідних даних вимагати від органів ринкового нагляду, що надали таку інфрормацію, доповнення інформації відсутніми даними.

Висновки і пропозиції. Підсумовуючи результати дослідження, можна зробити висновок, що база даних небезпечної продукції «UVAGA.GOV.UA» $€$ публічною версією системи оперативного взаємного сповіщення про продукцію, що становить серйозний ризик. Ї̈̈ утворення регулюється законами України «Про загальну безпечність нехарчової продукції», «Про державний ринковий нагляд і контроль нехарчової продукції», постановою Кабінету Міністрів України «Про затвердження Порядку функціонування системи оперативного взаємного сповіщення про продукцію, що становить серйозний ризик, та подання повідомлень для внесення до неї». База даних «UVAGA.GOV. UA» утворена центральним органом виконавчої влади, що реалізує державну політику у сфері економічного розвитку, з метою забезпечення доступу громадськості до інформації про небезпечну нехарчову продукцію, що передбачено відповідними нормами чинного законодавства. Отже, функціонування бази даних «UVAGA. GOV.UA» $€$ діяльністю органів державної влади, що сприяє забезпеченню прав населення на споживання безпечної продукції.

\section{Список використаної літератури:}

1. В Україні запустили базу небезпечних товарів UVAGA.GOV.UA / Управління Державної служби України з питань праці у Кіровоградській області. Опубліковано 19 липня 2019 р. URL: http://kr.dsp.gov.ua/index.php/4533-uv19-07-19.

2. Любімова С.Ю. Сутність адміністративно-правових засад діяльності приватних підприємств. Вісник ХНУВС. 2012. № 1 (56). С. 210-218.

3. Бандурка С.С. Адміністративно-правові засади діяльності приватного підприємства. Право.иа. 2017. № 2. C. 80-85.

4. Панова Н.С. Адміністративно-правові засади розвитку державного управління в сучасній Україні : авторефр. дис. ... канд. юрид. наук : 12.00.07. Одеса : ОНЮА, 2008. 24 с.

5. Легенький М.І. Категоріально-змістові передумови дослідження адміністративно-правових засад формування і реалізації державної політики у сфері освіти. Міжнародний науковий журнал «Інтернаука». Серія : «Юридичні науки». 2018. № 3 (8). С. 25-31.

6. Небезпечна продукція, виявлена на ринку. База даних «Uvaga.gov.ua». URL: http://uvaga. gov.ua/uk/Main/Category/Category.

7. Про загальну безпечність нехарчової продукції : Закон України від 2 грудня 2010 р. № 2736-VI. Верховна Рада України/Базаданих «Законодавство України». URL: https://zakon.rada.gov.ua/laws/show/2736-17\#Text.

8. Органи ринкового нагляду База даних "UVAGA.GOV.UA». URL: http://uvaga.gov.ua/uk/ Main/Agency/AgencyList.

9. Про державний ринковий нагляд і контроль нехарчової продукції: Закон України від 2 грудня 2010 р. № 2735-VI. Верховна Рада України. База даних «Законодавство Укра- 
їни». URL: https://zakon.rada.gov.ua/laws/show/ 2735-17\#Text.

10.Про затвердження Порядку функціонування системи оперативного взаємного сповіщення про продукцію, що становить серйозний ризик, та подання повідомлень для внесення до неї : Постанова Кабінету Міністрів України від 26 грудня 2011 р. № 1398. Верховна Рада України. База даних Законодавство України. URL: https://zakon.rada.gov.ua/laws/show/1398-2011$\%$ D0\%BF\#Text.

11. Про затвердження Технічного регламенту щодо медичних виробів : Постанова Кабінету Міністрів
України від 2 жовтня 2013 р. № 753. Офіційний вісник України. 2013. № 82. С. 158, Ст. 3046.

12.Про затвердження Технічного регламенту піротехнічних виробів : Постанова Кабінету Міністрів України від 3 серпня 2011 р. № 839. Урядовий кур'єр. 2011. № 148.

13.Дитячі товари. Інформація. Небезпечна продукція, виявлена на ринку. База даних "Uvaga.gov.ua». URL: http://uvaga.gov.ua/uk/ Main/Category/CategoryFilter?category=10806.

14. Медичні вироби. База даних «UVAGA.GOV.UA». URL: http://uvaga.gov.ua/uk/Main/Category/ CategoryFilter?category=10822.

\section{Aleksandrov M. Ye. Administrative and legal foundations of the functioning of the database of non-safety products "UVAGA.GOV.UA"}

The article examines the administrative and legal foundations of functioning of the database of non-safety products "UVAGA.GOV.UA". This database has been operating on the Internet since mid-2019. The website "UVAGA.GOV.UA" contains information about dangerous non-food products which had been found on the market. The site also provides information for consumers, business representatives and officials of state market supervision on the procedure for market surveillance and measures to prevent the sale of non-safety products.

The author aims to determine the administrative and legal foundations for the functioning of the database of non-safety products "UVAGA.GOV.UA". To achieve this goal, the author analyzed the interpretation of the term "administrative and legal foundations», on the basis of which the author provides a definition of administrative and legal foundations as grounds of the basis of the system, which established by administrative and legal norms. Next, the author determines on the grounds of which regulations the database of dangerous products operates, which authorities are responsible for its formation, how notifications about dangerous products are formed and, in fact, what is the purpose of the database "UVAGA.GOV.UA" functioning.

The formation of the concept of administrative and legal foundations was carried out using the method of analysis and the inductive method. Determining the grounds, principles, procedure and purpose of the functioning of the database "UVAGA.GOV.UA" was carried out by the comparative legal method and the method of analysis of regulations.

In the conclusions, the author notes that the administrative and legal foundations of functioning of the database of non-safety products "UVAGA.GOV.UA" are the rules of current legislation of Ukraine. This system is a public version of the system of prompt mutual notification of products that pose a serious risk, and was created to inform the public about the dangerous non-food products which had been found on the market. The creation and functioning of the database "UVAGA.GOV. $U A$ " helps to ensure consumer safety by preventing the use of products that pose a risk to human life and health.

Key words: administrative and legal foundations, database, product safety, non-safety products, state market supervision. 


\section{УДК 342.9}

DOI https://doi.org/10.32840/1813-338X-2020.3.12

\section{К. O. Кривошеєв}

аспірант кафедри адміністративного, господарського права

та фрінансово-економічної безпеки

Навчально-наукового інституту права

Сумського державного університету

\section{ПРАВООХОРОННІ ОРГАНИ ЯК СУБ'ЄКТИ ЗАБЕЗПЕЧЕННЯ ФІНАНСОВОÏ БЕЗПЕКИ УКРАЇНИ}

Стабільність фрінансової системи є надзвичайно важливою для держави, адже високий рівень захищеності такої системи від зовнішніх та внутрішніх загроз створює передумови для стабільного функціонування економіки країни та стабільного і дієвого виконання обов'язків органами державної влади, органами місцевого самоврядування щодо акумулювання фрінансових ресурсів. Наявність стабільної фрінансової системи дозволяє забезпечити ефрективний розвиток підприємництва та вкладення зарубіжних інвестицій у розвиток вітчизняного бізнесу без страху зазнати збитки. Таким чином, стабільність фрінансової системи прямо пов'язана із забезпеченням фрінансової безпеки держави.

Суб'єкти забезпечення фрінансової безпеки держави є ключовим елементом механізму забезпечення фрінансової безпеки. Суб'єкти забезпечення фрінансової безпеки держави - це суб'єкти фрінансових відносин, діяльність яких спрямована на своєчасне виявлення, попередження, нейтралізацію та ліквідацію загроз фрінансовій безпеці держави та проявляється через застосування системи інституиійно-правових та організаційних заходів впливу, або є тими суб'єктами, які своїми діями реалізувати конституційне право на фрормування органів державної влади, діяльність яких у подальшому тією чи іншою мірою буде спрямована на забезпечення фрінансової безпеки держави.

У даній статmі досліджено наукову категорію «правоохоронні органи», проаналізовано сучасні дослідження у сорері окреслення теоретико-правових особливостей поняття «правоохоронні органи». Проаналізовано такі нормативно-правові акти: Закон України «Про основи національної безпеки України»; Закон України «Про державний захист працівників суду і правоохоронних органів»; наказ «Про затвердження Інструкції про порядок проведення контрольних заходів контрольно-ревізійним відділом Державної судової адміністрації України»; Закон України «Про прокуратуру»; Закон України «Про державний захист працівників суду та правоохоронних органів»; Закон України «Про національну безпеку»; Закон України «Про національну поліцію»; Закон України «Про Державне бюро розслідувань»; Закон України «Про Службу безпеки України»; Закон України «Про Національне антикорупційне бюро України»; Закон України «Про основні засади здійснення державного фрінансового контролю в Україні»; Митний кодекс України; Податковий кодекс України.

Ключові слова: правоохоронні органи, фрінансова безпека держави, суб'єкти забезпечення фрінансової безпеки держави.

Постановка проблеми. Необхідно визначити адміністративно-правовий статус правоохоронних органів як суб'єктів забезпечення фрінансово-економічної безпеки в Україні, окреслити особливості їх діяльності та вплив на стан національної безпеки в державі.

Аналіз останніх досліджень та публікацій показав, що дослідження адміністративно-правового статусу правоохоронних органів $€$ надзвичайно актуальним для України, особливо після початку реформування податкової міліції. Останні дослідження Гаруста Ю.В.,
Мельника В.І., Куліша А.М. показали значимість правоохоронних органів у системі забезпечення фрінансово-економічної безпеки України.

Мета статті - дослідити правоохоронні органи як суб'єкти забезпечення фрінансової безпеки України.

Виклад основного матеріалу. Уперше визначення поняття «правоохоронні органи» у вітчизняній науці було надано А.М. Куліш, який запропонував розуміння даної категорії як багаторівневої соціальної системи, що включає систему правових засобів, методів та гарантій, 
які забезпечують охорону суспільних відносин від протиправних посягань, та державних органів, які виконують правоохоронні функції [1, с. 21].

О.М. Бандурка зазначає, що правоохоронні органи - це державні установи й організації, які функціонують у суспільстві та основним завданням діяльності яких є забезпечення законності, боротьби зі злочинністю та іншими правопорушеннями [2, с. 154].

Під категорією «правоохоронні органи» M.І. Мельник та М.І. Хавронюк запропонували розуміти державні органи, які, діючи в межах кримінально-процесуальної або адміністративної процедури, ведуть боротьбу зі злочинністю та правопорушеннями, що тягнуть за собою юридичну відповідальність у сфрері публічного права [3, с. 72].

На думку А. Колодія та А. Олійника, правоохоронні органи - це структуровані колективи службовців, що здійснюють державні і недержавні фрункції контролю, нагляду, досудового слідства, охорону і захист усіх форм власності, охорону природи, охорону прав, свобод та законних інтересів людини і громадянина, виконують інші правоохоронні функції [4, с. 254].

У свою чергу, Р. Тевлін до таких органів відносить всі державні органи, які наділені певними повноваженнями в галузі контролю за додержанням законності і правопорядку
[5, с. 52]. Аналогічну позицію у своїх дослідженнях висловлюють і Ю. Ведєрніков, А. Папна. До таких органів науковці віднесли: органи поліції, прокуратури, Служби безпеки України, охорони державних кордонів, Державної контрольно-ревізійної служби, Державної податкової служби, а також органи юстиції та адвокатури [6, с. 196].

У вітчизняному законодавстві надана значна кількість визначень поняття «правоохоронні органи», які закріплені і в законах України, і в підзаконних актах (таблиця 1). Вважаємо, що відсутність чіткого окреслення дефініції «правоохоронні органи» негативно впливає на діяльність правоохоронних органів, адже неточності та суперечки щодо їх адміністративно-правового статусу створюють перешкоди у виваженому та ґрунтовному окресленні компетенції та повноважень таких органів, соціально-правового статусу їх працівників.

На нашу думку, для положень чинного законодавства України характерним $€$ не визначення десрініції «правоохоронні органи» із чіткою характеристикою даного органу, окресленням його правового статусу та особливостей діяльності. Вектор декларування спрямований на перелік органів, які можуть бути віднесені до правоохоронних. Ураховуючи дану ситуацію, В. Півненко вказує на можливість розмежування переліку правоохоронних органів за

Визначення поняття «правоохоронні органи», закріплені в положеннях

Таблиця 1 чинного законодавства України

\begin{tabular}{|c|c|c|}
\hline $\begin{array}{l}\text { № } \\
\mathbf{n} / \mathbf{n}\end{array}$ & Термін & НПА \\
\hline 1. & $\begin{array}{l}\text { Правоохоронні органи - це органи, на які покладені спеціальні } \\
\text { завдання щодо гарантування державної безпеки і захисту } \\
\text { державного кордону України. }\end{array}$ & Конституція України від 28.06.1996 р. [7] \\
\hline 2. & $\begin{array}{l}\text { Правоохоронні органи - це органи державної влади, на які } \\
\text { Конституцією і законами України покладено здійснення право- } \\
\text { охоронних функцій. }\end{array}$ & $\begin{array}{l}\text { Закон України «Про основи національної } \\
\text { безпеки України» від 19.06.2003 №964-V [8] }\end{array}$ \\
\hline 3. & $\begin{array}{l}\text { Правоохоронні органи - це органи прокуратури, Національ- } \\
\text { ної поліції, служби безпеки, Військової служби правопорядку } \\
\text { у Збройних Силах України, Національне антикорупційне бюро } \\
\text { України, органи охорони державного кордону, органи доходів } \\
\text { і зборів, органи і установи виконання покарань, слідчі ізоля- } \\
\text { тори, органи державного фрінансового контролю, рибоохорони, } \\
\text { державної лісової охорони, інші органи, які здійснюють право- } \\
\text { застосовні або правоохоронні функції }\end{array}$ & $\begin{array}{l}\text { Закон України «Про державний захист } \\
\text { працівників суду і правоохоронних органів» } \\
\text { від 23.12.1993 № 3781-XII [9] }\end{array}$ \\
\hline 4. & $\begin{array}{l}\text { Правоохоронні органи - це органи прокуратури, внутрішніх } \\
\text { справ, служби безпеки, державної контрольно-ревізійної } \\
\text { служби та державної податкової служби }\end{array}$ & $\begin{array}{l}\text { Наказ Про затвердження Інструкції про } \\
\text { порядок проведення контрольних захо- } \\
\text { дів контрольно-ревізійним відділом } \\
\text { Державної судової адміністрації України } \\
\text { від 29.07.2011 № } 120 \text { [10] }\end{array}$ \\
\hline 5. & $\begin{array}{l}\text { Правоохранительные органы - это государственные органы, } \\
\text { которые в соответствии с национальным законодательством } \\
\text { Сторон обеспечивают безопасность государства, общества, } \\
\text { граждан и ведут борьбу с преступностью. }\end{array}$ & $\begin{array}{l}\text { Договір про порядок перебування та взає- } \\
\text { модії співробітників правоохоронних орга- } \\
\text { нів на територіях держав-учасниць СНД } \\
\text { від 04.06.1999 р. [11] }\end{array}$ \\
\hline
\end{tabular}


гілками влади. Так, науковець пропонує правоохоронними органами виконавчої гілки влади визначити Міністерство внутрішніх справ України, Службу безпеки України, Державну прикордонну службу України тощо; правоохоронними органами законодавчої гілки влади - Уповноваженого Верховної Ради України із прав людини та Рахункову палату; правоохоронними органами судової гілки влади - загальні та спеціальні суди. Окреме місце в даній системі органів дослідник виділяє для органів прокуратури. В. Півненко стверджує, що прокуратура за своїм статусом посідає особливе місцеве та виступає як спеціальний конституційний орган [12, с. 264]. При цьому дослідник звертає увагу на сам Закон України «Про прокуратуру» від 14 жовтня 2014 р. № 1697-VII, який не відносить органи прокуратури до правоохоронних. У відповідності до частини 1 статті 1 даного Закону Прокуратура України становить єдину систему, яка в порядку, передбаченому цим Законом, здійснює встановлені Конституцією України функції з метою захисту прав і свобод людини, загальний інтерес суспільства та держави [13].

Ураховуючи все вищевикладене, вважаємо, що правоохоронні органи - це система державних органів, основним завданням діяльності яких $є$ виконання функцій правоохоронної діяльності на підставі положень чинного законодавства України, яка полягає в гарантуванні державної безпеки, захисті державного кордону, охороні і захисті прав, свобод і законних інтересів держави і населення.

Досліджуючи питання статусу правоохоронних органів, які забезпечують фрінансову безпеку державу, та чіткого окреслення переліку таких органів, окремі дослідники посилаються на положення статті 2 Закону України «Про державний захист працівників суду та правоохоронних органів» від 23 грудня 1993 р. Зокрема, О.М. Рєзнік стверджує, що саме дане положення законодавства України дає підстави вважати, що до системи правоохоронних органів, які забезпечують фінансову безпеку держави, можна віднести виключно органи Національної поліції України, органи Служби безпеки України, органи прокуратури, підрозділи податкової міліції Державної фріскальної служб України та Національне антикорупційне бюро України [2, с. 36].

Але звертаючись до змісту даного Закону, зазначимо, що в ньому надається характеристика поняттю «правоохоронні органи» та перелічено, які саме органи можна віднести до правоохоронних. Більш того, в жодному положенні не надано характеристики поняттю «правоохоронні органи, які забезпечують фрінансову безпеку держави», а зміст поняття «правоохоронні органи» значно ширший, ніж вказує дослідник, та включає: «органи прокуратури, Національної поліції, служби безпеки, Військової служби правопорядку у Збройних Силах України, Національне антикорупційне бюро України, органи охорони державного кордону, органи доходів і зборів, органи і установи виконання покарань, слідчі ізолятори, органи державного фрінансового контролю, рибоохорони, державної лісової охорони, інші органи, які здійснюють правозастосовні або правоохоронні функції» [14].

Звертаємо увагу, що положенням Закону України «Продержавний захист працівників суду та правоохоронних органів» від 23 грудня 1993 р. все ж таки не надано вичерпний перелік правоохоронних органів, а саме положення завершується словами: «... інші органи, які здійснюють правозастосовні або правоохоронні функції».

Ураховуючи той фракт, що фрінансова безпека $\epsilon$ складовою частиною національної безпеки, то, звертаючись до змісту Закону України «Про національну безпеку», зазначимо, що даний нормативно-правовий акт закріплює перелік державних органів, одним із завдань яких $€$ забезпечення національної безпеки і оборони країни, це: Міністерство оборони України, Збройні Сили України, Державна спеціальна служба транспорту, Міністерство внутрішніх справ України, Національна гвардія України, Національна поліція України, Державна прикордонна служба України, Державна міграційна служба України, Державна служба України з надзвичайних ситуацій, Служба безпеки України, Управління державної охорони України, Державна служба спеціального зв'язку та захисту інформації України, Апарат Ради національної безпеки і оборони України, розвідувальні органи України, центральний орган виконавчої влади, що забезпечує фрормування та реалізує державну військово-промислову політику [15].

Звертаємо увагу, що на законодавчому рівні надано лише загальний перелік органів, які забезпечують національну безпеку держави. Тому пропонуємо, базуючись на ключових завданнях та меті діяльності таких органів, виокремити ті, з них, які функціонують із метою забезпечення фрінансової безпеки України.

У відповідності до частини 1 статті 1 Закону України «Про національну поліцію» від 05.07.2015 р. № 580-VIII Національна поліція України - це центральний орган виконавчої 
влади, який служить суспільству шляхом забезпечення охорони прав і свобод людини, протидії злочинності, підтримання публічної безпеки і порядку [16].

Слушною з даного приводу $€$ позиція О.О. Сосновик, В.І. Мельника та Ю.В. Гаруста, які зазначають, що хоча не всі завдання Національної поліції направлені на забезпечення фінансової безпеки держави, однак більшість із них все ж таке мають економічне забарвлення. У зв'язку із чим даний державний орган можна віднести до суб'єктів забезпечення фінансової безпеки держави.

Законом України «Про Державне бюро розслідувань» від 12.11.2015 р. № 794-VIII частиною 1 статті 1 прямо закріплено, що Державне бюро розслідувань $є$ державним правоохоронним органом, на який покладаються завдання щодо запобігання, виявлення, припинення, розкриття та розслідування злочинів, віднесених до його компетенції [17]. Аналізуючи положення даного Закону та визначені ключові завдання діяльності Державного бюро розслідування, вважаємо за можливе віднести даний орган до суб'єктів забезпечення фінансової безпеки з огляду на наступне. Так, один із аспектів діяльності державного органу спрямований на протидію корупційним правопорушенням, які негативно впливають на загальний стан фінансової системи та економіки країни.

Законом України «Про Службу безпеки України» від 25.03.1992 р. № 2229-ХІІ визначено, що Служба безпеки України - державний орган спеціального призначення з правоохоронними функціями, який забезпечує державну безпеку України. До завдань Служби безпеки України також входить попередження, виявлення, припинення та розкриття злочинів проти миру і безпеки людства, тероризму, корупції та організованої злочинної діяльності у сфері управління і економіки та інших протиправних дій, які безпосередньо створюють загрозу життєво важливим інтересам України [18].

Таким чином, те, що Служба безпеки України $€$ суб'єктом забезпечення фінансової безпеки $€$ безспірним фактом. Адже у змісті нормативного положення чітко закріплено, що на Службу безпеки України покладено захист економічного потенціалу, попередження, виявлення, припинення та розкриття злочинів у сфері корупційної діяльності, у сорері управління та економіки.

Питанню протидії корупційним правопорушенням в законодавстві України приділено значну увагу. Так, Законом України «Про Наці- ональне антикорупційне бюро України» від 14.10.2014 р. №1698-VII визначено, що Національне антикорупційне бюро України є державним правоохоронним органом, на який покладається попередження, виявлення, припинення, розслідування та розкриття корупційних правопорушень, віднесених до його підслідності, а також запобігання вчиненню нових [19]. Таким чином, до списку суб'єктів забезпечення фінансової безпеки України можна також віднести і Національне антикорупційне бюро України.

На нашу думку, особливим органом у системі суб'єктів забезпечення фінансової безпеки $\epsilon$ Прокуратура України, адже чинним законодавством України прямо не передбачені повноваження органу у фінансово-економічній сфері. Однак, статтею 2 Закону України «Про прокуратуру» від 14.10.2014 № 1697-VII на прокуратуру покладаються функції нагляду за додержанням законів органами, що провадять оперативно-розшукову діяльність, дізнання, досудове слідство [13].

Митним кодексом України від 13.03.2012 № 4495-VI закріплено призначення митних органів, яке полягає у створенні сприятливих умов для розвитку зовнішньоекономічної діяльності, забезпечення безпеки суспільства, захист митних інтересів України. Вважаємо, що за фрактом виконання покладених на митні органи завдані, вони прямо впливають на економіку в країні та загальний стан забезпеченості фінансової безпеки [20].

Реалізує митну та державну політику у сфері боротьби з правопорушеннями під час застосування законодавства з питань державної митної справи Державна митна служба України, яка і є суб'єктом забезпечення фрінансової безпеки держави

У свою чергу, реалізація податкової політики закріплена за Державною податковою службою України, яка у відповідності до Положення про Державну податкову службу України, затвердженого постановою Кабінету Міністрів України від 06.03.2019 р. № $227 \epsilon$ центральним органом виконавчої влади, діяльність якого спрямовується i координується Кабінетом Міністрів України через Міністра фінансів і який реалізує державну податкову політику, державну політику 3 адміністрування єдиного внеску на загальнообов'язкове державне соціальне страхування [21].

У складі Державної фріскальної служби України та її територіальних підрозділів функціонують підрозділи податкової міліції, ключовими 
завданнями яких $€$ : запобігання кримінальним та іншим правопорушенням у ссрері оподаткування та бюджетній сфрері, їх розкриття, розслідування та провадження у справах про адміністративні правопорушення; розшук осіб, які переховуються від слідства та суду за кримінальні та інші правопорушення у сфері оподаткування та бюджетній сфері; запобігання і протидія корупції в контролюючих органах та виявлення ії фрактів; забезпечення безпеки діяльності працівників контролюючих органів, захисту їх від протиправних посягань, пов'язаних із виконанням службових обов'язків [22].

Із приводу визначення статусу податкової міліції та її місця в забезпечення фрінансової безпеки в Україні слушною є позиція В.І. Мельника та Ю.В. Гаруста, які, досліджуючи питання визначення суб'єктів забезпечення фрінансової безпеки, констатували, що більшість завдань даного органу спрямована на забезпечення та підтримку належного рівня фінансово-економічної складової частини державної безпеки в Україні [5, с. 35]. Таким чином, податкова міліція також може розглядатися як суб'єкт забезпечення фрінансової безпеки держави.

У відповідності до пункту 1 Положення про Державну аудиторську службу України, затвердженого постановою Кабінету Міністрів України від 03.02.2016 р. № 43, Державна аудиторська служба України $є$ центральним органом виконавчої влади, діяльність якого спрямовується і координується Кабінетом Міністрів України через Міністра фінансів та який реалізує державну політику у сфрері державного фрінансового контролю [23].

На підставі змісту Положення про Державну аудиторську службу України, затвердженого постановою Кабінету Міністрів України від 03.02.2016 р. № 43, можемо стверджувати, що даний орган $\epsilon$ органом державного фрінансового контролю. Згідно зі статтею 2 Закону України «Про основні засади здійснення державного фрінансового контролю в Україні» від 26.01.1993 № 2939-XII головними завданнями органу державного фрінансового контролю є: здійснення державного фінансового контролю за використанням і збереженням державних фінансових ресурсів, необоротних та інших активів, правильністю визначення потреби в бюджетних коштах та взяттям зобов'язань, ефективним використанням коштів і майна, станом і достовірністю бухгалтерського обліку і фрінансової звітності в міністерствах та інших органах виконавчої влади, державних фондах, фондах загальнообов'язкового державного соціального страхування, бюджетних установах і суб'єктах господарювання державного сектору економіки, а також на підприємствах, в установах та організаціях, які отримують (отримували у періоді, який перевіряється) кошти з бюджетів усіх рівнів, державних фондів та фрондів загальнообов'язкового державного соціального страхування або використовують (використовували в періоді, який перевіряється) державне чи комунальне майно, за дотриманням бюджетного законодавства, дотриманням законодавства про закупівлі, діяльністю суб'єктів господарської діяльності незалежно від фрорми власності, які не віднесені законодавством до підконтрольних установ, за судовим рішенням, ухваленим у кримінальному провадженні [24].

Висновки і пропозиції. Отже, правоохоронні органи у сфері забезпечення фрінансової безпеки виконують життєво важливі для всього суспільства завдання. Однак ані в законодавстві Україні, ані в науковій літературі не вироблено єдиного підходу до визначення правоохоронних органів, які є суб'єктами забезпечення фрінансової безпеки. Разом із тим, дослідивши положення чинного законодавства України, а також позиції провідних юристів-дослідників із питань забезпечення фрінансово-економічної безпеки в Україні, можемо стверджувати, що правоохоронними органи, які є суб'єктами забезпечення фінансової безпеки України, є Національна поліція, Державне бюро розслідування, Служба безпеки України, Національне антикорупційне бюро України, Прокуратура України, Державна митна служба України, Державна податкова служба України, податкова міліція, Державна аудиторська служба України. Більш того, враховуючи проведене дослідження щодо теоретичного окреслення категорії «правоохоронні органи, що забезпечують фрінансову безпеку держави», вважаємо за можливе розуміти систему державних органів, основним завданням діяльності яких $€$ виконання функції правоохоронної діяльності у сфері публічних фінансів та фрінансової безпеки, що полягає в гарантуванні такої безпеки та захисті прав, свобод і законних інтересів держави і населення.

\section{Список використаної літератури:}

1. Куліш А.М. Правоохоронна система України: адміністративно-правові засади організації та фуункціонування : автореф. дис. ... д-ра юрид. наук: 12.00.07. Харків : ХНУВС, 2009. 31 С. 
2. Судебные и правоохранительные органы Украины : учебник / под ред. А.М. Бандурки. Харків : Університет внутрішніх справ, 1999. 350 с.

3. Мельник М.І. Правоохоронні органи та правоохоронна діяльність : навч. посіб. Київ : Атіка, 2002. 576 c.

4. Правознавство : підручник / А. Колодій, А. Олійник. Київ : Правова єдність ВАВ, 2009. 792 с.

5. Тевлін Р. Про поняття «правоохоронні органи» у широкому та вузькому розумінні. Радянське право. 1985. № 7. С. 51-54.

6. Теорія держави і права : навчальний посібник / С. Бостан, С. Гусарєв, Н. Пархоменко та ін. Київ : ВЦ «Академія», 2013. 348 с.

7. Конституція України від 28.06.1996 р. URL : https://zakon.rada.gov.ua/laws/show/254\%D0\% BA/96-\%D0\%B2\%D1\%80.

8. Про основи національної безпеки України : Закон України від 19.06.2003 № 964-V. URL : https://zakon.rada.gov.ua/laws/show/964-15.

9. Про державний захист працівників суду і правоохоронних органів: Закон України від 23.12.1993 № 3781-XII. URL : https://zakon.rada.gov.ua/laws/show/3781-12.

10.Про затвердження Інструкції про порядок проведення контрольних заходів контрольно-ревізійним відділом Державної судової адміністрації України : Наказ від 29.07.2011 № 120. URL : https://zakon.rada.gov.ua/laws/show/z0749-05.

11.Договір про порядок перебування та взаємодії співробітників правоохоронних органів на територіях держав-учасниць СНД від 04.06.1999 p. URL : https://zakon.rada.gov.ua/ laws/show/997_836.

12.Півненко В. Прокурорський нагляд в Україні : навч. посібник. Харків : Харків юридичний, 2008. 304 c.

13.Про прокуратуру : Закон України від 14 жовтня 2014 p. № 1697-VII. URL : https://zakon.rada.gov. ua/laws/show/1697-18.
14.Про державний захист працівників суду та правоохоронних органів : Закон України від 23 грудня 1993 p. URL : https://zakon.rada.gov.ua/ laws/show/3781-12.

15.Про національну безпеку : Закон України від 21.06.2018 р. № 2469-VIII. URL : https://zakon.rada.gov.ua/laws/show/2469-19.

16.Про національну поліцію: Закон України від 05.07.2015 р. № 580-VIII. URL : https://zakon.rada.gov.ua/laws/show/580-19.

17.Про Державне бюро розслідувань : Закон України від 12.11.2015 р. № 794-VIII. URL : https://zakon.rada.gov.ua/laws/show/794-19.

18.Про Службу безпеки України : Закон України від 25.03.1992 р. № 2229-XII. URL : https://zakon.rada.gov.ua/laws/show/2229-12.

19.Про Національне антикорупційне бюро України : Закон України від 14.10.2014 p. № 1698-VII. URL : https://zakon.rada.gov.ua/laws/ show/1698-18.

20.Митний кодекс України від 13.03.2012. № 4495-VI. URL : https://zakon.rada.gov.ua/laws/ show/4495-17.

21.Про Державну податкову службу України затвердженої постановою Кабінету Міністрів України : Положення від 06.03.2019 р. № 227. URL : https://zakon.rada.gov.ua/laws/show/2272019-\%D0\%BF.

22.Податковий кодекс України від 02.12.2010 № 2755-VI. URL : https://zakon.rada.gov.ua/laws/ show/2755-17.

23.Про Державну аудиторську службу України, затвердженого постановою Кабінету Міністрів України: Положення від 03.02.2016 р. № 43. URL : https://zakon.rada.gov.ua/laws/show/432016-\%D0\%BF.

24.Про основні засади здійснення державного фрінансового контролю в Україні : Закон України від 26.01.1993 № 2939-XII. URL : https://zakon.rada.gov.ua/laws/show/2939-12.

Kryvosheyev K. O. Law enforcement authorities as subjects of financial security of Ukraine

The stability of the financial system is extremely important for the state, because the high level of protection of such a system from external and internal threats creates the preconditions for stable functioning of the economy and stable and effective performance of duties by public authorities and local governments to accumulate financial resources. The presence of a stable financial system allows to ensure the effective development of entrepreneurship and foreign investment in the development of domestic business without fear of loss. Thus, the stability of the financial system is directly related to ensuring the financial security of the state.

The subjects of financial security of the state are a key element of the mechanism of financial security. Subjects of financial security of the state are subjects of financial relations, whose activity is aimed at timely detection, prevention, neutralization and elimination of threats to financial security of the state and is manifested through the application of a system of institutional, legal and organizational measures, or are those subjects, which by their actions to exercise the constitutional right to form public authorities, whose activities in the future to some extent will be aimed at ensuring the financial security of the state.

This article examines the scientific category of "law enforcement agencies", analyzes modern research in the field of outlining the theoretical and legal features of the concept of "law enforcement 
agencies". The following normative legal acts are analyzed: Law of Ukraine "On Fundamentals of National Security of Ukraine"; Law of Ukraine "On State Protection of Court and Law Enforcement Officials"; order "On approval of the Instruction on the procedure for conducting control measures by the control and audit department of the State Judicial Administration of Ukraine"; Law of Ukraine "On the Prosecutor's Office"; Law of Ukraine "On State Protection of Court Employees and Law Enforcement Bodies"; Law of Ukraine "On National Security"; Law of Ukraine "On the National Police"; Law of Ukraine "On the State Bureau of Investigation"; Law of Ukraine "On the Security Service of Ukraine"; Law of Ukraine "On the National Anti-Corruption Bureau of Ukraine"; Law of Ukraine "On the basic principles of public financial control in Ukraine"; Customs Code of Ukraine; Tax Code of Ukraine.

Key words: law enforcement agencies, financial security of the state, subjects of ensuring financial security of the state. 


\section{УДК 342.9}

DOI https://doi.org/10.32840/1813-338X-2020.3.13

\section{Е. О. Маркова}

кандидат юридических наук, доцент, доцент кафедры юридических дисциплин

Сумского филиала Харьковского национального университета внутренних дел

\section{К ВОПРОСУ ОБ ОБЪЕКТИВИЗАЦИИ РЕЗУЛЬТАТОВ АДМИНИСТРАТИВНОЙ ПРОЦЕДУРЫ}

В статье автор исследует вопрос, связанный с формой объективизации результатов административной процедуры. Эфрфективность использования органами публичной администрации форм управленческой деятельности обеспечивается установлением их процессуальной формы. Управленческая деятельность в целом и, в частности, административно-процедурная должна быть юридически (административно-правовым образом) фрормализована: в ней должны содержаться основания совершения управленческих действий, необходимость их совершения, важнейшие этапы разработки проектов индивидуальных актов, процедуры принятия, контроля за исполнением. Эфрфективность использования органами публичной администрации форм управленческой деятельности обеспечивается установлением их процессуальной фрормы. Управленческая деятельность в целом и, в частности, административно-процедурная должна быть юридически (административно-правовым образом) формализована: в ней должны содержаться основания совершения управленческих действий, необходимость их совершения, важнейшие этапы разработки проектов индивидуальных актов, процедуры принятия, контроля за исполнением. Деятельность органов в административной процедуре осуществляется именно посредством административно-процедурной фоормы, которая связана с позитивными действиями, разрешением бесспорных индивидуальных дел, с принятием индивидуальных правоприменительных административных актов. Она регулирует взаимодействие в рамках правоотношения двух субъектов по схеме «частное лицо - должностное лицо (административного органа)» или наоборот.

В рамках исследования данного вопроса мы пришли к выводу о том, что необходимо ввести в научный оборот понятие «форма административно-процедурной деятельности» с целью исключения путаницы и дуальности в понимании «процессуальной фрормы». Автор предлагает, в рамках своего исследования, использовать понятие фрормы административно-процедурной деятельности органов публичной администрации как способа объективизации результатов процедуры.

Проведя компаративистский обзор на предмет существующих фрорм объективизации результатов административной процедуры, считаем необходимым выделить общее и специальные фрормы.

Ключевые слова: административная процедура, форма административно-процедурной деятельности, объективизация.

Постановка проблемы. В нашем исследовании мы рассматриваем административную процедуру как нормативно установленный унифицированный порядок осуществления деятельности административным органом, направленный на ограничение административного усмотрения при реализации органом дискреционных полномочий в отношениях с гражданами, юридическими лицами в форме, установленной законом.
Деятельность органов в рамках административной процедуры является правоприменительной, поскольку направлена на установление индивидуальных правовых последствий - субъективных прав и обязанностей, и их реализацию путем принятия индивидуального правового решения в отношении персонифицированных субъектов - правоприменительного акта [1, с. 173]. Правовой результат деятельности органов публичной 
администрации отображается в принятии административного акта (индивидуального акта управления), который является одной из форм публичного (государственного) управления - деятельности органов публичной администрации. Под органами публичной администрацией в украинском административном праве понимают органы исполнительной власти и органы местного самоуправления. Составляющей частью правоприменительной деятельности вышеуказанных органов является административно-процедурная деятельность, которая осуществляется в установленных формах и соответствующими методами.

Цель работы - осуществить доктринальный обзор подходов ученых в отношении понятий, выработанных наукой: «форма управленческой детальности», «процессуальная форма», и предложить авторское понятие, а также провести компаративистский обзор существующих форм объективизации результатов.

Основной материал. В общем смысле понятие «форма» означает: 1) способ существования содержания, неотделимый от него и служащий его выражением; 2) внешнее выражение какого-либо содержания [2].

В административно-правовой литературе это понятие чаще всего связывают с управленческой деятельностью органов государственной власти.

Под формой управленческой деятельности понимают «внешние постоянно и типизированно фриксируемые выражения (проявления) практической активности государственных органов по формированию и реализации управленческих целей и функций и обеспечению их собственной жизнедеятельности» [3, с. 245], «внешнее практическое выражение конкретных действий, совершаемых органами государственного управления в целях и в процессе исполнительной и распорядительной деятельности», «внешне выраженное действие исполнительного органа (должностного лица), осуществленное в рамках его компетенции и вызывающее определенные последствия» [4, с. 68], «внешнее выражение практической реализации функций и методов управления, самого управляющего воздействия, конкретных действий, производимых в процессе осуществления исполнительной власти, административной деятельности [5, с. 323]. И хотя в юридической литературе преимущественно речь идет именно о «форме государственного управления», поддерживаем позицию ученых, которые считают, что это понятие можно использовать и в отношении деятельности органов публичной администрации, употребляя понятие «форма деятельности публичной администрации», или как переходную конструкцию - «форма публичного управления» [6, с. 98].

Традиционно формы деятельности органов публичной администрации делятся на правовые и неправовые, в зависимости от того, порождают или нет правовые последствия (вызывают возникновение юридического эффректа). Наука административного права ограничивается обработкой прежде всего вопросов издание индивидуальных актов управления (административных актов), нормативных актов управления, а с недавних пор - также проблематикой заключения административных договоров.

Для нас интерес представляют правовые формыуправленческойдеятельности, поскольку они имеют юридическое установление и содержание, которое влекут советующие правовые последствия. Ученые проводят классификацию правовых форм по различным критериям.

На сегодняшний день в науке среди правовых форм управленческой деятельности выделяют: а) издание нормативных правовых актов; б) издание ненормативных и индивидуальных правовых; в) заключение административных договоров; в) осуществление юридически значимых действий (проведение государственной регистрации, выдача официальных документов, разрешающих. осуществление определённой деятельности). Во всех правовых формах публичного управления (административно-правовых формах) отчетливо проявляются властные полномочия государственных, исполнительных органов, выраженные в действиях субъектов управленческой деятельности, которые влекут определенные юридические последствия, а в законодательных и иных нормативных актах предусматривается четкая правовая регламентация правовых форм, устанавливается юридический способ их выражения.

В западноевропейской административноправовой литературе рассматриваются несколько видов форм публичного управления (форм осуществления управленческих действий). Например, германскими учеными выделяются следующие формы управления: 1) правотворчество (постановления, уставы, административные предписания); 2) административные акты; 3) публично-правовые договоры; 4) простое административное действие; 5) частно-правовая административная дея- 
тельность (например, предоставление субсидий). Германскими учеными анализируются при этом многочисленные типы управленческих решений и особо указывается на высокую значимость в процессе осуществления публичного управления планирования.

Понятие «форма публичного управления» тесно связано с административной процедурой, поскольку каждый вид формы управленческой деятельности органов публичной администрации реализуется и осуществляется в рамках конкретной административной процедуры. Органы публичной администрации в лице должностных лиц в каждом конкретном случае в зависимости от сути административного дела выбирают форму, в которой будет отображаться результат их деятельности. Выбор формы подчинен определенным правилам: она должна соответствовать компетенции данного органа (и соответствующих должностных лиц), назначению, функциям, правовым методам управленческой деятельности, характеру разрешаемых вопросов, целям управляющего воздействия, особенностям конкретного объекта; она может распространяться лишь на тепостановление объекты, которые находятся в пределах ведения соответствующего управляющего органа (должностного лица).

При этом важно указать, что должны использоваться только те формы управления, которые предусмотрены действующим законодательством. То есть речь идет о процедурно-правовом регулировании осуществления той или иной формы государственного управления в целом, и в частности органов исполнительной власти и местного самоуправления. Важно отметить, что в настоящее время в Украине отсутствует надлежащая законодательная регламентации фрорм управленческой деятельности, что предопределяет необходимость принятия нормативного акта, регулирующего административную процедуру. В противном случае будут возникать вопросы, связанные с: правомерностью использования той или иной формы, последствий, которые она создает для адресатов, процедурой в рамках, которой она была принята. Вместе с тем это не означает, что орган лишен возможности выбора той или иной формы в каждом конкретном административном деле. При осуществлении управленческой деятельности органы публичной администрации имеют возможность выбирать форму управления по своему усмотрению в пределах, установленных действующим законодатель- ством. Но для того чтобы минимизировать злоупотребление или превышение органами своих полномочий в административной процедуре, необходимо не только принять Закон «Об административной процедуре», но и закрепить в нем положения об основных формах, в которых должны отображаться результаты процедуры. Под фиксированным результатом мы понимаем любой правовой результат, обладающий следующими признаками:

1) он предусмотрен компетенцией данного государственного органа (должностного лица);

2) он создает определенные субъективно-правовые последствия для обратившегося в государственный орган (к должностному лицу) субъекта;

3) без его наличия (объективации) невозможно наступление стадии процедуры.

Эффрективность использования органами публичной администрации форм управленческой деятельности обеспечивается установлением их процессуальной формы. Управленческая деятельность в целом и, в частности, административно-процедурная должна быть юридически (административно-правовым образом) формализована: в ней должны содержаться основания совершения управленческих действий, необходимость их совершения, важнейшие этапы разработки проектов индивидуальных актов, процедуры принятия, контроля за исполнением.

Необходимо отметить, что на сегодняшний день среди ученых сложилось противоречивое мнение об использовании понятия «процессуальной формы» в управленческой деятельности органов публичной администрации в целом и, в частности, в административной процедуре. Это связано с рядом причин: 1) с отсутствием единства во взглядах в отношении понятия «процессуальной формы», ее субъектного и предметного содержания, а предложенные в юридической литературе формулировки подменяют собой содержание других правовых институтов (речь идет об правовой процедуре); 2) с развитием общей теории юридического процесса и отраслевых наук, которые сегодня широко используют понятие «правовая процедура», нуждается в уточнении содержания понятие «процессуальная форма», таким образом, чтобы оно не совпадало с содержанием других правовых понятий и не приводило к путанице и дуальному пониманию. Поэтому предлагаем в рамках нашего исследования использовать понятие формы административ- 
но-процедурной деятельности органов публичной администрации (административно-процедурная форма) как способа объективизации результатов процедуры.

Деятельность органов в административной процедуре осуществляется именно посредством административно-процедурной фооры, которая связана с позитивными действиями, разрешением бесспорных индивидуальных дел, с принятием индивидуальных правоприменительных административных актов. Она регулирует взаимодействие в рамках правоотношения двух субъектов по схеме «частное лицо - должностное лицо (административный орган)» или наоборот.

Проблема правового установления процедурного порядка совершения управленческих действий и принятия государственно-властных решений является сегодня в Украине одной из наиболее острых. Неурегулированность административных процедур весьма ощутимо проявляется в практике публичной управленческой деятельности, и особенно серьезные последствия возникают в сфрере обеспечения и защиты прав и свобод граждан.

В настоящее время осуществление деятельности органов в административной процедуре в Украине имеет минимум правовой регламентации, что, естественно, влечет за собой такие негативные еe характеристики, как недемократичность, малоэфффективность, произвольность и неправомерность действий.

Во всех европейских странах институт административной процедуры урегулирован на законодательном уровне (закон либо кодекс), на котором прямо закреплена фрорма, где объективируется результат деятельности (действий) органов в административной процедуре. Учитывая необходимость развития нашего государства в европейском направлении, принципиально важно учитывать подходы к рассмотрению данного вопроса в странах Европейского Союза.

Используя компаративистикой подход, мы обратимся к зарубежному законодательному и доктринальному опыту с целью проведения обзора существующих фрорм объективизации результатов процедуры.

В украинском проектном законодательстве предусмотрено, что результаты административной процедуры находят свою объективизацию в форме принятия индивидуального административного акта. Действующее украинское законодательство понятие «административный акт» не употребляет, однако в проекте Закона Украины «Об административном акте» и Административно-процедурного кодекса Украины дается определение данному понятию, под которым понимают решение индивидуального действия, принятое административным органом, направленное на установление, изменение или прекращение прав и выполнения обязанностей фризической / юридическим лицом (лицами). Таким образом, украинское проектное законодательство закрепляет понятие «административного акта» в качестве индивидуального решения, касающегося прав, свобод и законных интересов конкретных лиц.

В законодательстве европейских стран об административной процедуре одной из распространённых форм является «административный акт», однако его содержания разное. Например, во Франции практически все, что исходит от администрации и носит публичный характер, считается административными актами, которые могут быть односторонними, двусторонними или многосторонними, индивидуальными и нормативными. К административным актам, acte administratif, во Франции относят и административные соглашения [7, с. 115] (широкое толкование понятия). Хотя не исключено, что в данном случае различия в подходах могут быть обусловлены и трудностями перевода, ведь во французском языке конструкция близка к термину «административный акт» «акт администрации» (acte de l'administration). Однако в большинстве стран Европы административными актами являются только индивидуальные решения и действия.

В законодательстве ФРГ понятие административного акта, verwaltungsakt, является центральной категорией административно-правовой доктрины, под ним понимается «любое распоряжение, решение, направленное органом власти на урегулирование частного случая в сорере публичного права и имеющее непосредственные внешние правовые последствия» [8, с. 54]. В Польше административным актом считается властное юридическое действие административного органа, направленное на возникновение конкретных, индивидуально определенных юридических последствий.

В общем, в подходах к пониманию понятия административного акта в Европе доминирует именно немецкая доктрина. В частности, в документах Совета Европы, Европейской Комиссии и Европейского суда по правам человека под термином «административный акт» 
понимается любое индивидуальное решение: а) принятое при осуществлении публичной власти; б) имеющее характер прямого действия и правомерно или неправомерно касающееся прав, свобод и интересов частных лиц; в) не является актом, который исполняется при осуществлении судебных функций [9, с. 1].

Итак, используемое в данном исследовании понятие «административный акт» является индивидуальным актом, который направлен на создание, изменение или прекращение прав и обязанностей лица (лиц).

Поскольку целью нашей статьи не является анализ всех существующих форм административной процедуры, в которых объективируется ее результат, мы остановимся лишь на обзоре ее видов. А следующею статью посвятим анализу и содержательной характеристике указанных нами форм. В Германии, кроме формы - административного акта, используются еще и такие, как: постановление, в котором объективируются результаты процедуры по утверждению планов; публично-правовой договор, который административный орган может заключать с лицом, взамен издания административного акта. Проанализировав законодательство об административной процедуре, в частности Кодекс и французскую доктрину, выделим три вида форм административных актов в зависимости от действий органов публичной администрации в рамках административной процедуры: 1) подразумеваемые решения, 2) односторонние административные акты, 3) административный контракт.

В Польской доктрине используется общее понятие Rozstrzygnięcia, что в переводе означает решение, принятое на основании положений Кодекса административного производства, которое являются не только одной из основных форм урегулирования административного дела (разрешения), а также может использоваться для решения вопросов, возникающих в ходе производства. Решение, в зависимости от содержания, может называться так: decyzје administracyjną - админисративное решение, postanowienia, ugoda- договор [10].

Проведя компаративистский обзор на предмет существующих форм объективизации результатов административной процедуры, считаем необходимым отметить следующие особенности: в законодательстве ФРГ, Польши, Франции представлено процедурное разнообразие форм, среди которых можем выделить общее и специальные формы. Под общей формой понимаем «административный акт» и «административный договор», однако в законодательстве разных странах имеет разное название, однако общим является прилагательное «административный» (административный акт, административное решение, агентское решение и административный договор, административное соглашение, контракт, публично-правовой договор), в котором находят отражения действия органов и результаты административной процедуры. Под специальными - все остальные формы, которые мы указывали выше, специфика которых зависит от типа административной процедуры, вида нормотворчества. В проектном украинском законодательстве предусмотрена только одна форма - административный акт. В следующей статье мы постараемся ответить на вопрос: почему в проектном законодательстве предусмотрена только одна форма и насколько данное положение отвечает современным мировым требованиям и тенденциям развития административной процедуры.

\section{Список использованных источников:}

1. Адміністративне право України. Академічний курс : підруч. : у двох томах: Том 1. Загальна частина / Ред. колегія: В.Б. Авер'янов (голова). Київ : Видавництво «Юридична думка», 2004. С. 173.

2. Энциклопедический словарь Брокгауза и Eфрона. URL : http://gatchina3000.ru/brockhausand-efron-encyclopedic-dictionary/ 108/108175. htm. - Інформація станом на 25 липня 2007 року.

3. Атаманчук Г.В. Теория государственного управления: курс лекций. Москва , 2004. С. 243-244.

4. Советское административное право : учебник для вузов / под ред. Ю.М. Козлова. Москва, 1985. С. 174.

5. Старилов Ю.Н. Административное право : в 2 ч. Ч. 2. Кн. 2: Формы и методы управленческих действий. Правовые акты управления. Административный договор. Воронеж : из-во Воронежского государственного университета. 2001. 432 с.

6. Школик А.М. Порівняльне адміністративне право : навч. посібник для юридичних факультетів та фракультетів міжнародних відносин. Львів : ЗУКЦ, 2007. С. 104.

7. Зіллер Ж. Політико-адміністративні системи країн ЄС. Порівнял. аналіз / Пер. 3 фр. В. Ховхуна. Київ : Основи, 1996. С. 241.

8. §35Закону ФРНпроадміністративнупроцедуру. Текст станом 5 травня 2004 року. Адміністративні процедури і адміністративне судочинство. Збірник матеріалів Німецького фонду 
міжнародного правового співробітництва. Київ, 2006. С. 54.

9. Видання Ради Європи «Адміністрація і Ви. Принципи адміністративного права, що стосуються відносин між адміністративною владою і приватними особами» (переклад неофіційний). 1996. С. 1.

10.M. Jaroszyński, M. Zimmermann, W. Brzeziński, Polskie prawo administracyjne. Część ogólna,
Warszawa 1956, s. 320 i n.; J. Starościak, Prawne formy działania administracji, Warszawa 1957, s. 71 i n.; J. Borkowski, Decyzja administracyjna, Warszawa 1970, s. 56 i n.; E. Ochendowski, Prawo administracyjne. Część ogólna, Toruń 2002, s. 159 i n.; K. Ziemski, Formy prawne działania administracji publicznej, [w:] Aktualne problemy administracji i prawa administracyjnego, pod red. J. Posłusznego, Przemyśl 2003, s. 150 i n.

Markova E. O. To the question of objectivation of the results of the administrative procedure In the article, the author examines the issue related to the form of objectification of the results of the administrative procedure. The effectiveness of the use of forms of management activity by public administration bodies is ensured by the establishment of their procedural form. Management activity in general, and in particular administrative-procedural, should be formalized legally (in an administrative-legal way): it should contain the grounds for committing managerial actions, the need for them, the most important stages in the development of draft individual acts, the procedure for adoption, and control over execution. The effectiveness of the use of forms of management activity by public administration bodies is ensured by the establishment of their procedural form. Management activities in general, and in particular administrative-procedural activities, should be formalized legally (in an administrative-legal way): it should contain the grounds for committing managerial actions, the need to perform them, the most important stages in the development of draft individual acts, the procedure for adoption, control over execution. The activities of the authorities in the administrative procedure are carried out precisely through the administrative-procedural form, which is associated with positive actions, the resolution of indisputable individual cases, with the adoption of individual law enforcement administrative acts. It regulates interaction within the framework of the legal relationship of two subjects according to the scheme: a private personofficial (administrative body) or vice versa.

As part of the study of this issue, we came to the conclusion that it is necessary to introduce into the scientific circulation the concept of "form of administrative and procedural activity" in order to eliminate confusion and duality in the understanding of "processual form". The author proposes, within the framework of his research, to use the concept of the form of administrative and procedural activities of public administration bodies as a way to objectify the results of the procedure. Having conducted a comparative review on the subject of existing forms of objectifying the results of an administrative procedure, we consider it necessary to highlight the general and special forms.

Key words: administrative procedure, form of administrative and procedural activity, objectification. 
УДК 34:336.719.2 (477)

DOI https://doi.org/10.32840/1813-338X-2020.3.14

Ю. Ю. Пустовіт

кандидат юридичних наук, доцент, доцент кафедри адміністративного, фрінансового та інформаційного права Київського національного торговельно-економічного університету

\section{О. В. Запотоцька}

доктор юридичних наук, доцент, доцент кафедри адміністративного, фрінансового та інформаційного права

Київського національного торговельно-економічного університету

B. О. Тімашов

доктор юридичних наук, доцент, професор кафеери адміністративного, фрінансового та інформаційного права Київського національного торговельно-економічного університету

\section{СЬОГОДЕННЯ АДМІНІСТРАТИВНОЇ ВІДПОВІДАЛЬНОСТІ ЮРИДИЧНИХ ОСІБ}

Статтю присвячено проблемам, що створюється у процесі реалізації багатьох змін як у політичному, так і в економічному характері правових норм, та їхньому впливу на юри-

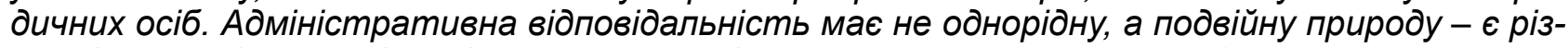
новидом юридичної відповідальності та адміністративного примусу. Стаття присвячена аналізу специфрічних ознак, притаманних саме адміністративній відповідальності. Звертається увагу на те, що адміністративна і кримінальна відповідальність мають багато спільних ознак: як юридична відповідальність, вони мають публічну природу та захищають публічний інтерес, однак існують і відмінні риси, які і дають всі підстави для розмежування з огляду на притягнення до відповідальності юридичних осіб. Виражена у статті інформація може використовуватися під час теоретичного обірунтування та практичного розроблення методики реалізації, через норми законодавства такого правового інституту, як адміністративна відповідальність юридичних осіб.

У даній роботі досліджено підстави для адміністративної відповідальності юридичних осіб. Проаналізовано загальні тенденції в сучасному адміністративному праві, пов'язані з форммуванням правового інституту відповідальності юридичних осіб.

Досліджено проблеми застосування заходів адміністративної відповідальності як інструменту захисту прав і свобод суб'єктів адміністративних відносин. Виділено основні ознаки адміністративної відповідальності для юридичних осіб.

Проаналізовано типовий склад адміністративних правопорушень юридичних осіб. Проведено комплексний аналіз адміністративних стягнень за правопорушення юридичних осіб та, на основі цього, визначено недоліки, які впливають на ефрективність їх практичного застосування. Виділено основні матеріально-правові та прочесуально-правові особливості адміністративної відповідальності.

На основі досліджених матеріалів були сфрормульовані пропозиції та рекомендації для вдосконалення регулювання у сфрері відповідальності юридичних осіб, які спрямовані на регулювання порушень щодо юридичних осіб в адміністративному праві.

Ключові слова: юридичні особи, адміністративна відповідальність, суспільні відносини, застосування стягнень. 
Постановка проблеми. Адміністративна відповідальність $€$ важелем впливу для дотримання порядку та охорони прав та свобод усіх суб'єктів правовідносин. У цій сфрері важливу роль відіграють і юридичні особи. тому велике значення має й адміністративна відповідальність, пов'язана з ними.

Правове регулювання у сфері адміністративної відповідальності юридичних осіб є важливим для дотримання порядку.

Вплив загальнообов'язкових правил для юридичних осіб створює належний правовий режим для створення суспільних відносин, що відповідають інтересам держави.

Серед засобів, які держава застосовує для боротьби з порушенням законодавства, найвагоміше місце посідає адміністративна відповідальність. Зокрема, дієвим засобом у боротьбі з правопорушеннями у ссрері адміністративної відповідальності юридичної особи є превентивні заходи та заходи примусу.

Аналіз останніх досліджень і публікацій з даної теми. У теорії адміністративного права адміністративній відповідальності в минулому відводилося одне з перших місць. Цій проблематиці викладено багато наукових праць, до них можна віднести багато дослідників, таких як: Є.С. Герасименко, І.П. Голосніченко, О.А. Зима, С.С. Єсімов, Л.. Кравченко, Ю.А. Колесниченко, В.А. Крижановська, В.А. Кротюк, О.І. Лук'янець, О.Г. Літус, М.В. Удод, С.А. Шепетько та інші.

Однак тільки декілька були присвячені адміністративній відповідальності юридичних осіб. У цих працях основну увагу було присвячено узагальненню підстав такої відповідальності та доказуванню самого факту їх виникнення.

Тому проблема залишається актуальною і потребує подальшого опрацювання.

Метою наукового дослідження $є$ аналіз стану правового забезпечення адміністративної відповідальності юридичних осіб, визначення проблем правового регулювання адміністративної відповідальності юридичних осіб, а також можливих шляхів їх вирішення.

Виклад основного матеріалу. До сутності адміністративної відповідальності різні автори підходять неоднаково.

Варто зазначити, що останнім часом проблеми адміністративної відповідальності не так часто обговорюються на сторінках юридичних видань. Це можна пояснити тим, що на рівні державної влади виявлена необхідність розробки нового Кодексу, що має замінити чинний Кодекс України про адміністративні правопорушення (надалі КУпАП) [1].
Він діє вже більше ніж тридцять років та зберігає багато неправильних підходів до регулювання адміністративної відповідальності. Наприклад, визнання суб'єктом цієї відповідальності лише фрізичних осіб - громадян України, іноземців та осіб без громадянства.

Так, це твердження було затверджено свого часу Конституційним Судом України. У Кримінальному кодексі України передбачено вірогідність використання заходів правового характеру для юридичної особи, адміністративне ж законодавство залишається в цьому питанні практично незмінним.

Декілька слів необхідно сказати про особливості вітчизняного законодавства щодо правопорушень у сфері адміністративного права. Об'єднання нормативно правових актів в адміністративний кодекс зроблено ще в 1980 роках, на основі радянської практики до розуміння сутності відповідальності в адміністративному праві, її змісту та суб'єктів.

У радянській системі юридичні особи не визнавалась суб'єктами адміністративної відповідальності щодо каральної відповідальності. КУпАП був розрахований на застосування лише для фізичної особи. Із того часу в адміністративно-правовому регулюванні відбулось багато змін [1].

У наш час КУпАП вже реалізує варіанти залучення до відповідальності юридичних осіб. Згідно із частиною 1 статті 14-2 зазначається, про адміністративну відповідальність за правопорушення забезпечення безпеки дорожнього руху несуть відповідальність як фізичні особи, так і юридичні особи, що до яких зареєстровано транспортний засіб [1].

Так, у відношенні закону юридичних осіб уже визнано суб'єктами адміністративної відповідальності. Варто відзначити, що в Господарському кодексі України намагались перелічити загальні правила для відповідальності юридичних осіб, яку в даному нормативно правому акті називають адміністративно господарською відповідальністю [2].

Цей термін вживається в зазначеному кодексі не тільки щодо санкцій та відповідальності суб'єктів господарювання, а й щодо відносин, які становлять предмет його регулювання загалом, однак цим самим у ньому поєднано два несумісні поняття.

Адміністративні правовідносини $€$ видом публічно-правових відносин, заснованих на нерівності сторін, підпорядкуванні їх, коли в господарських правовідносинах вони проявляються як приватноправові відносини, де сто- 
рони будуть рівними. Відносин, де сторони одночасно $є$ рівними та нерівними, не можуть бути [3].

Так, у тих випадках, коли в Господарському кодексі йдеться про «адміністративно-господарські» дії, насправді важливо говорити про адміністративно правові значення.

Це стосується, зокрема, й «адміністративно-господарських» санкцій, в яких відповідно до ст. 217 Господарського кодексу можуть застосовуватись до суб'єктів господарювання за ініціативою відповідних органів державної влади або місцевого самоврядування [2].

Проте, зазначивши недосконалість у Господарському кодексі України з точки зору розділення предметів регулювання різних галузей права, добрим було б відзначити визнання ним можливості застосування до юридичних осіб заходів адміністративної відповідальності, якими, без сумніву, є «адміністративно-господарські» санкції [2].

У нормативних актах, що регулюють адміністративну відповідальність, санкції, які застосовуються до юридичних осіб, мають назву не тільки «штрафр», а й, «заходи впливу» чи «фінансові санкції» й інші, хоча за змістом це все випадки застосування майнового впливу за недотримання загальнообов'язкових правил, тобто штраф [4].

Через те, що йдеться про використання цих санкцій в адміністративному порядку, такий штрафр $€$ не чим іншим, як адміністративним покаранням, тому, йдеться про адміністративну відповідальність. В обґрунтування даного висновку зазначимо декілька аргументів [5].

По-перше, адміністративна відповідальність - це відповідальність, яка не має компенсаційну мету, яка властива майновій відповідальності. Штраф, що накладається відповідно до перерахованих законів, стягується на користь держави, тобто мета цих санкцій однозначно каральна [4].

По-друге, адміністративна відповідальність наступає через вчинення особливого виду правопорушення, що має назву «адміністративне».

Такіпорушення регулярнішезаіншіполягають у недотриманні різноманітних загальнообов'язкових правил, тобто таких правил, що діють у відносинах державного керування і за недотримання яких і встановлено відповідну санкцію.

Якщо взяти до уваги Закон України «Про телебачення i радіомовлення», то в ньому йдеться про застосування покарання до телерадіоорганізацій та провайдерів програмної послуги, якщо ними порушено вимоги даного нормативно правого акту та умов ліцензії [5].
У преамбулі даного нормативного акту зазначено, що цей закон регулює відносини, які можуть виникнути у сфрері телевізійного та радіомовлення на території України та визначає правові, економічні, соціальні, організаційні умови їх фрункціонування. Тому можна мати на увазі порушення саме загальнообов'язкових правил, тобто вчинення адміністративних правопорушень.

По-третє, що, можливо, $€$ найвагомішим фрактором, реалізується адміністративна відповідальність в адміністративному порядку, тобто без звернення до суду [6].

Заходи адміністративної відповідальності застосовуються великою кількістю органів і посадовими особами - представниками публічної адміністрації, що мають назву «суб'єкти адміністративної юрисдикції».

Самете, щоадміністративнавідповідальність регулярно реалізується в судовому порядку, за останні роки викликає навіть суперечки серед науковців щодо належності цього правового інституту до інститутів адміністративного права.

Судовий порядок відповідальності дає підстави для висновку, що ця відповідальність вже не геть адміністративна, причому зберігається тенденція до постійного поширення кількості проступків, справ, які розглядаються суддями [7].

Проте з позицією, відповідно до якої відносини адміністративної відповідальності не можна вважати управлінськими, а значить, вони не відповідають адміністративно-правовому регулюванню, складно згодитись.

Тому адміністративна відповідальність знову буде регламентуватись в управлінських відносинах суб'єктами публічного управління, що й властиво для відносин, які регулюються адміністративним правом [8].

На даний момент поняття та види кримінальних проступків у нормативно правових актах не закріплені. Повертаючись до адміністративної відповідальності юридичних осіб, варто відмітити, що в нормативно правових актах, які її регулюють, зазначають як адміністративний, так і судовий порядок використання санкцій. Існування першого свідчить, що ця відповідальність $€$ очевидно адміністративною [9].

У вищевказаному Законі «Про телебачення і радіомовлення» прямо вказується те, що за недотримання норм про телебачення і радіомовлення телерадіоорганізації провайдери програмної послуги, їхні керівники та робітники чи інші суб'єкти які мають відношення до господарської діяльності, відповідні особи органів державної влади та органів місцевого само- 
врядування нестимуть виключно кримінальну, цивільно правову та адміністративну відповідальність згідно із законодавством України.

Тому виходячи з наведеного вище, можна стверджувати що юридична особа за порушення законодавства має нести відповідальність, а саме адміністративне стягнення.

Згідно з пунктом 22 частини 1 статті $92 \mathrm{KoH}-$ ституції України [10] лише закони України визначають діяння, за які існує адміністративна відповідальність.

Законодавство про адміністративні правопорушення має визначати загальні правила адміністративної відповідальності юридичних осіб.

Повертаючись до Закону «Про телебачення і радіомовлення», згідно зі ст. 72 вказано, що Національна рада України з питань телебачення і радіомовлення використовує санкції до телерадіоорганізацій та провайдерів програмної послуги, якщо нимипорушено вимогиданогонормативно правового акту та ліцензійних умов [5].

Однак якихось чітких правил розгляду таких справ, гарантій для осіб, які притягаються до відповідальності, закон не визначає. У даній статті зазначена можливість заперечення рішення щодо стягнення штрафу в судовому розгляді. Регламент даного заперечення ніде не визначено [11].

Висновки. Отже, з огляду на все вищевикладене вбачається нагальна необхідність затвердження Кодексу про адміністративні проступки, проект даного кодексу на даний момент розроблений і переданий на розгляд до Верховної Ради України. У вищезазначеному Кодексі чітко не тільки зазначено в згрупованому вигляді підстави використання до юридичних осіб адміністративних стягнень, насамперед штрафу, але й установлено загальні правила та процедури притягнення їх до цієї відповідальності, що, безумовно, сприятиме забезпеченню законності.

\section{Список використаної літератури:}

1. України про адміністративні правопорушення від 7 грудня 1984 № 8073-Х. Офріційний сайт Верховної Ради України. URL : https://zakon.rada.gov.ua/laws/show/8073110 (дата звернення: 30.03.2020).

2. Господарський кодекс України. Прийнятий 16 січня 2003 р. Відомості Верховної Ради України. 2003. № 18, № 19-20, № 21-22. Офіційний сайт Верховної Ради України. URL : https://zakon.rada.gov.ua/laws/show/436-15 (дата звернення: 30.03.2020).

3. Кримінальний кодекс України від 5 квітня 2001 № 341-III. Офріційний сайт Верховної Ради України. URL : https://zakon.rada.gov.ua/laws/ show/2341-14 (дата звернення: 30.03.2020).

4. Кравченко Л. Проблеми адміністративної відповідальності юридичних осіб у сфері валютного законодавства. Юридичний журнал. 2004. № 8. C. 69-72.

5. Зауваження до проекту Порядку фрормування Переліку програм іноземних телерадіоорганізацій, що ретранслюються. URL : https://blogs.pravda.com.ua/authors/golovan/ 5b7d41124bcb5/ (дата звернення: 30.03.2020).

6. Кримінальний процесуальний кодекс України від 13 квітня 2012 № 4651-VI. Офріційний сайт Верховної Ради України. URL : https://zakon.rada.gov.ua/laws/show/ 4651-17 (дата звернення: 30.03.2020).

7. Цивільний кодекс України від 16 січня 2003 № 435-VI. Офріційний сайт Верховної Ради України. URL : https://zakon.rada.gov.ua/laws/ show/435-15 (дата звернення: 30.03.2020).

8. Про внесення змін до деяких законодавчих актів України щодо спрощення досудового розслідування окремих категорій кримінальних правопорушень: Закон України від 03.12.2019 № 17, ст. 71 (зі змінами). Офіційний сайт Верховної Ради України. URL : https://zakon.rada. gov.ua/laws/show/2617-19 (дата звернення: 30.03.2020).

9. Про затвердження розмірів штрасрів, які можуть накладатися на телерадіоорганізації та провайдерів програмної послуги за порушення законодавства про телебачення і радіомовлення: Рішення № 03/03 від 24 жовтня 2014 року. Офіційний сайт Національної ради України з питань телебачення та радіомовлення. URL : https://www.nrada.gov.ua/ community_council_documents/rishennya-03-03pro-rozmiry-shtrafiv-yaki-mozhut-nakladatysya-nateleradioorganizatsiyi-ta-provajderiv-programnoyiposlugy-za-porushennya-zakonodavstva-protelebachennya-radiomovlennyal (дата звернення: 30.03.2020).

10.Конституція України від 28 червня 1996 року № 30 (зі змінами). Офріційний сайт Верховної Ради України. Режим доступу. URL : https://zakon.rada.gov.ua/laws/show/254к/96-вр (дата звернення: 30.03.2020).

11. Навчальний посібник з адміністративної відповідальності Україні. URL: http://theoldtree.ru/ gosudarstvo_i_pravo/administrativna_ vidpovidalnist_v_ukrain_2.php. (дата звернення: 30.03.2020). 


\section{Pustovit Yu. Yu., Zapototska O. V., Timashov V. O. Current administrative responsibility of legal entities}

The article is devoted to the problem that is created in the process of implementation of many changes in political and economic nature, and their impact for legal entities. Administrative liability is not homogeneous, but dual in nature - it is a kind of legal liability and administrative coercion. The article is devoted to the analysis of specific features inherent in administrative responsibility. Bearing in mind that administrative and criminal liability have many common features: as legal liability, they have a public nature and protect the public interest, but there are also distinctive features that give every reason to differentiate, given the prosecution of legal entities.

The information expressed in the article can be used in the theoretical substantiation and practical development of the method of implementation through the rules of law of such a legal institute, such as administrative liability of legal entities.

This paper investigates the grounds for administrative liability of legal entities. General trends in modern administrative law related to the formation of the legal institute of liability of legal persons are analyzed.

The problems of application of measures of administrative responsibility as a tool of protection of rights and freedoms of subjects of administrative relations are investigated. The main features of administrative responsibility for legal entities are highlighted.

The typical composition of administrative offenses of legal entities is analyzed. A comprehensive analysis of administrative penalties for the offense of legal entities was conducted and, on the basis of this, the shortcomings that affect the effectiveness of their practical application were identified. The main substantive and procedural peculiarities of administrative responsibility are highlighted.

Based on the researched materials, proposals and recommendations were formulated to improve regulation in the area of liability of legal entities aimed at regulating violations against legal persons in administrative law.

Key words: legal entities, administrative responsibility, social relations, enforcement of penalties. 
УДК $342.9+303.052$ (303.093.3)

DOI https://doi.org/10.32840/1813-338X-2020.3.15

Л. Т. Рябовол

доктор педагогічних наук, професор, профресор кафредри державно-правових дисциплін

та адміністративного права

Центральноукраїнського державного педагогічного університету імені Володимира Винниченка

\section{ЗАБЕЗПЕЧЕННЯ БЕЗПЕКИ ЯК НАУКОВА ПРОБЛЕМА: РЕАЛІЗАЦІЯ СИСТЕМНОГО ПІДХОДУ ДО ДОСЛІДЖЕННЯ}

Актуальність теми обгрунтована тим, що на сучасному етапі світового розвитку забезпечення безпеки - суттєва ознака суверенітету держави і водночас чинник ії незалежності й самостійності, а також важливий напрям діяльності уповноважених суб'єктів. Meта статmi - провести аналіз позицій науковців щодо структурування феноменів забезпечення різних видів безпеки та запропонувати авторське бачення узагальненої системи забезпечення безпеки. Встановлено, що забезпечення безпеки, незалежно від їі виду, вчені переважно розглядають як феномен зі складною структурою. Необхідність і доцільність реалізації системного підходу до дослідження проблеми забезпечення безпеки зумовлено тим, що саме системний підхід дозволяє розглянути френомен забезпечення безпеки найбільш повно і комплексно, в єдності й цілісності закономірно розташованих і взаємопов'язаних компонентів та елементів з урахуванням впливу різноманітних чинників. Узагальнену систему забезпечення безпеки розроблено як взаємоузгоджену сукупність цільового, об'єктного, суб'єктно-організаційного та результативного компонентів. Цільовий компонент презентовано як сукупність наступних елементів - мети, завдань та принципів діяльності із забезпечення безпеки. Об'єктний компонент - як єдність предмету (інтереси та цінності, які потребують захисту), носіїв цих інтересів і власників цінностей, а також загроз і небезпек цим інтересам і цінностям. Виокремлено такі елементи суб'єктно-організаційного компоненту: суб'єкти забезпечення певного виду безпеки; методи, засоби, інструменти, механізм їх діяльності; ресурсне забезпечення. Виявлено, що результат фрункціонування системи забезпечення безпеки дозволяє встановити рівень ї дієвості та визначити напрямки їі подальшого удосконалення і в цьому полягає значення результативного компонента досліджуваної системи. Констатовано, що формування і розвиток системи забезпечення безпеки певного виду зумовлюють різноманітні чинники - внутрішні / зовнішні, національного / глобального характеру, конструктивні / деструктивні.

Ключові слова: система, безпека, система забезпечення безпеки, загроза, небезпека, суб'єкти забезпечення безпеки.

Постановка проблеми. У сучасному глобалізованому світі, який позначається посиленням традиційних загроз та появою нових ризиків, питання забезпечення безпеки вимагає нагального вирішення. Наразі спостерігається тенденція до абсолютизації безпеки як базового критерію фрункціонування усього живого, а забезпечення безпеки, зокрема в рамках безпекоцентризму (форма світогляду, в рамках якого безпека $\epsilon$ мірилом під час вирішення будь-яких питань, а центральне місце, через яке опосередковуються усі інші види і фрорми діяльності, посідає забезпечення безпеки об'єкта) філософрського напряму, обґрунтованого В. Ліп- каном [1, с. 125], можливо розглядати як суттєву ознаку суверенітету держави і водночас чинник ії незалежності (політичної, економічної тощо) й самостійності, а також як важливий напрям діяльності уповноважених суб'єктів.

Аналіз останніх досліджень та публікацій. Проблема забезпечення безпеки притягує інтерес фрахівців з різних галузей знань. Із позицій юриспруденції питання забезпечення національної безпеки вивчали В.О. Антонов, Ю.В. Нікітін, Г.В. Новицький, В.Ф. Смолянюк та ін. Предметом правових досліджень було забезпечення різних видів безпеки: інформаційної (Т.Ю. Ткачук та ін.); екологічної (Л.О. Ємець 
та ін.); митної (О.І. Попівняк, Д.В. Пудрик, O.I. Разумова та ін.). Питання державного управління у сфері забезпечення безпеки розробляли С.П. Завгородня, О.В. Комаров, Т.І. Крук, В.М. Пасічник, М.М. Разумей, А.В. Рубан, Г.П. Ситник та ін. У контексті досліджень з економіки безпекові питання вивчали О.В. Вертелєва, М.О. Губа, В.В. Даценко, О.Є. Денисов, О.В. Джумурат, Є.С. Жураківський, С.В. Козловський, М.М. Левко, І.В. Новосад, П.В. Пашко, П.Я. Пісной, О.В. Рудковський, С.В. Шевчук та ін. Загалом проблематика забезпечення безпеки розроблена достатньо ґрунтовно, однак вона не втрачає своєї актуальності. Особливий науковий інтерес викликає забезпечення безпеки як система, складноструктуроване явище, чим і зумовлена тема і мета нашої статті.

Мета статті - провести аналіз позицій науковців щодо структурування френоменів забезпечення різних видів безпеки та запропонувати авторське бачення узагальненої системи забезпечення безпеки.

Виклад основного матеріалу дослідження. Аналіз визначень поняття «безпека», закріплених у законодавстві, засвідчив, що законодавець визначає безпеку як «відсутність неприпустимого ризику», «відсутність загрози», «відсутність ризику, пов'язаного з можливістю спричинення шкоди та/або нанесення збитку», «стан, при якому ризик шкоди чи ушкодження обмежений до прийнятного рівня», водночас і як «властивість об'єкта забезпечувати відсутність ризику», «комплекс заходів, а також людські і матеріальні ресурси, які призначені для захисту», «запобігання» [2]. Тобто безпека тлумачиться і як відсутність загроз чи ризиків, і як відповідний стан, і як властивість (здатність) забезпечувати такий стан, і як комплекс відповідних заходів. Наразі не можна не погодитися з В.А. Ліпканом, який виокремив чотири основні підходи до трактування безпеки: статичний (як стан захищеності), апофратичний (як відсутність загроз і небезпек), діяльнісний (як система заходів щодо створення безпечних умов), пасивний (як дотримання певних параметрів та норм, від забезпечення яких залежить безпека) [1, с. 362, 363].

У найбільш загальному розумінні безпеку можливо визначити як відсутність загроз і небезпек, стан захищеності від них інтересів та цінностей особи, суспільства, держави, стан, за якого забезпечено оптимальні умови функціонування й розвитку перелічених суб'єктів. Так чи інакше, суттєвою ознакою безпеки постає її забезпеченість. В Академічному тлумачному словнику української мови остання визначена як створення надійних умов для здійснення чого-небудь; гарантування чого-небудь; захист, охорона кого-, що-небудь від небезпеки [3, с. 18], отже, безпосередньо безпека тісно пов'язана із забезпеченням безпеки як такої.

Як справедливо зазначає Ю.В. Нікітін, безпека - загальне поняття якості буття, яке може застосовуватися для означення багатьох явищ, віддзеркалює не тільки притаманні певному явищу специфічні ознаки безпеки, але і поглинає в себе її загальні риси (фактори), що і дає змогу застосовувати його в багатьох галузях; як відносна, а не абсолютна, категорія, безпека має значення тільки у сфері конкретної життєдіяльності людини чи суспільства [4, с. 142]. Таку наукову позицію поділяє В.О. Антонов, який вказує, що безпека не існує сама по собі, ізольовано чи у відриві від загальної людської життєдіяльності, а тісно пов'язана з усіма аспектами життя людини, суспільства та держави, де головною iï функцією $є$ забезпечення належних умов їх існування та подальшого розвитку [5, с. 15].

Передусім звернемося до категорії «національна безпека», яка позначає багатовимірне, багатоаспектне й багатофрункціональне явище державно-правової дійсності. Складна структура національної безпеки зумовлена складністю будови суспільного життя, значною кількістю його сфрер та об'єктів, які потребують безпечних умов. Це дозволяє виокремити різні види безпеки - економічну, податкову, митну, екологічну, інформаційну тощо, забезпеченням яких у сукупності й досягається національна безпека.

Досліджуючи державне управління у сорері забезпечення національної безпеки України C.І. Крук вказав на такі відповідні інституційні елементи, як: об'єкти захисту (територія, державні та суспільно-політичні інститути, політичні права і свободи, політична діяльність громадян, соціальних груп і об'єднань тощо); система відповідних нормативних актів (правова основа), а також погляди, принципи, концепції, доктрини, стратегії тощо; система суб'єктів (інститутів публічної влади), покликаних захищати суспільно-політичну сфреру й забезпечувати її розвиток; засоби, методи, способи забезпечення національної безпеки; критерії оцінки стану ефективності механізму її забезпечення [6, с. 14]. В.Ф. Смолянюк розглядає забезпечення національної безпеки як сукупність теоретико-методологічних, нормативно-правових, інформаційно-аналітичних, кадрових, 
організаційно-управлінських, розвідувальних, контррозвідувальних, оперативно-розшукових, науково-технічних, ресурсних та інших заходів, спрямованих на мінімізацію загроз і небезпек, гарантування розвитку національних інтересів, духовного і матеріального добробуту народу України [7, с. 115].

Як вже зазначалося, безпека тісно пов'язана з її забезпеченням, із захистом від загроз і небезпек, що чітко простежується у визначеннях різних видів безпеки, сутність яких розкривається вченими 3 використанням категорій «захист», «захищеність», «забезпечення». Так, економічну безпеку тлумачать як: складне полісистемне явище, розвиток якого зумовлений об'єктивною необхідністю забезпечувати відтворення національної економіки в умовах внутрішніх і зовнішніх загроз та небезпек (Є.С. Жураківський, С.В. Козловський) [10, с. 38]; такий стан економіки та інститутів влади, завдяки якому забезпечується гарантований захист національних інтересів, гармонійний соціально спрямований розвиток країни, достатній економічний та оборонний потенціал, навіть у випадку найбільш несприятливих варіантів розвитку внутрішніх і зовнішніх процесів (В.С. Альошкін, Т.В. Калінеску, О.О. Недобєга) [11, с. 309].

Безпосередньо під забезпеченням економічної безпеки розуміють: організовану сукупність суб'єктів (державних органів, посадових осіб, громадян, їх спілок), які об'єднані цілями та завданнями щодо захисту економічних інтересів та здійснюють свою діяльність відповідно до визначених у законодавстві фрункцій, механізмів їх виконання (О.В. Джумурат) [8, с. 80]; сукупність взаємопов'язаних і взаємообумовлених механізмів (правових, організаційних тощо) і суб'єктів забезпечення економічної безпеки, скоординована діяльність яких спрямована на виявлення, прогнозування, попередження і нейтралізацію загроз економічній безпеці та реалізацію національних інтересів в економічній сорері (Г.П. Ситник, С.П. Завгородня) [9, с. 88].

Митну безпеку визначають як: сукупність ефективних економічних, правових, політичних та інших механізмів, спрямованих на захист інтересів суб'єктів господарювання та держави в зовнішньоекономічній сфрері і, зокрема, в митній сфрері [12, с. 97]; захищеність митних інтересів суб'єктів господарювання, держави і міжнародної спільноти, за якої забезпечуються сталий розвиток, своєчасне виявлення, запобігання і нейтралізація реальних і потенційних загроз національним інтересам у митній сфері та інших сфрерах державного управління при виникненні негативних тенденцій до створення потенційних або реальних загроз національним інтересам, нейтралізація яких входить у компетенцію митних органів (М.М. Левко) [13, с. 17]; комплекс ефективних економічних, правових, політичних та інших заходів держави із захисту інтересів народу та держави в митній сфері $[14$, с. $53 ; 11$, с. 307]. Забезпечення митної безпеки розуміють як: упровадження в митній справі сукупності заходів, здатних протидіяти внутрішнім і зовнішнім загрозам та викликам у сфері зовнішньоекономічних відносин (І. В. Новосад) [15, с. 148]; правову можливість і спроможність уповноважених суб'єктів якісно і профресійно реалізовувати функції, які на них покладені державою; особливий правовий порядок діяльності уповноважених суб'єктів із забезпечення виконання учасниками митних відносин загальнообов'язкових правил у сфрері державної митної справи (О.І. Попівняк) [16, с. 90]; врегульовану нормами права виконавчо-розпорядчу діяльність спеціально уповноважених на те суб'єктів, спрямовану на підтримання належного стану захищеності митних інтересів від будь-яких загроз, що виникають у ході здійснення державної митної служби (Д.В. Пудрик) [17, с. 108]; впровадження в митній справі сукупності засобів, здатних протидіяти внутрішнім і зовнішнім загрозам та викликам у сфрері митних економічних відносин, забезпечити досягнення необхідного рівня захищеності, надійності та усталеності митної служби шляхом створення ефрективного регуляторного організаційно-економічного механізму (Т.І. Єфименко, П.В. Пашко, В.Ю. Хомутиннік та ін.) [18, с. 42].

Аналіз наведених визначень свідчить, що забезпечення безпеки, незалежно від iї виду, досліджується як складна система, у структурі якої виокремлюють такі складники: об'єкти - безпосередньо інтереси й цінності, які підлягають захисту; мета відповідної діяльності - забезпечення стану захищеності інтересів; реалізація національних інтересів у певній сфрері, виявлення, прогнозування, попередження та нейтралізація загроз безпеці; організована сукупність суб'єктів забезпечення безпеки та їх цілеспрямована і скоординована діяльність, а також сукупність відповідних взаємопов'язаних і взаємообумовлених механізмів (правових, організаційних тощо).

Очевидно, що саме системний підхід, в основі якого $€$ розуміння будь-якого складного явища як єдності, цілісності закономірно 
розташованих і взаємопов'язаних компонентів та елементів, забезпечує комплексність і повноту дослідження проблеми забезпечення безпеки, дозволяє вийти за межі розгляду забезпечення безпеки суто як сукупності заходів та засобів, певного механізму і дослідити це явище у широкому розумінні як сукупність взаємодіючих складників з урахуванням впливу різноманітних чинників. Наразі узагальнену систему забезпечення безпеки можливо презентувати як цілісність, єдність цільового, об'єктного, суб'єктно-організаційного та результативного компонентів, які $€$ взаємопов'язаними і взаємообумовленими.

Цільовий компонент, у свою чергу, містить такі елементи, як: а) мета; б) завдання; в) принципи відповідної діяльності. Цей компонент $\epsilon$ системотвірним. Не можна не погодитися з О.О. Астаховим, Є.Б. Смірновим і В.І. Ткаченком у тому, що мета $€$ основою забезпечення безпеки. Без ії визначення не $€$ можливим поступальний розвиток на шляху ефективного вирішення проблем безпеки життєдіяльності людини, суспільства й держави [19, с. 4]. Слід зазначити, що мета цієї, як і будь-якої іншої, системи фрактично є бажаним, очікуваним результатом її функціонування і має корелювати з результатом досягнутим, що буде свідчити про ефективність системи.

Елементами об'єктного компоненту $\epsilon$ : а) предмет - інтереси, які потребують захисту; б) носії інтересів і власники цінностей, які підлягають захисту у рамках цієї системи; в) загрози й небезпеки певним інтересам, своєчасне виявлення та повне усунення яких $є$ умовою забезпечення безпеки.

Суб'єктно-організаційний компонент охоплює такі елементи, як: а) суб'єкти, покликані забезпечувати відповідний вид безпеки, їх завдання і фрунції, компетенції та повноваження, якими вони наділені у зв'язку із цим; б) взаємоузгоджена діяльність уповноважених суб'єктів, організація, проведення ними відповідних заходів та застосування засобів, методів, інструментів, механізмів; в) ресурсне забезпечення діяльності суб'єктів забезпечення безпеки. У найбільш широкому розумінні до суб'єктів забезпечення певного виду безпеки можливо віднести суб'єктів відповідних правовідносин, фізичних та юридичних осіб приватного і публічного права, які можуть виступати учасником цих правовідносин та наділені необхідним обсягом правосуб'єктності. Очевидно, що місія суб'єктно-організаційного компонента в системі забезпечення безпеки є надзвичайно важливою. Ступінь досягнення мети функціонування усієї системи забезпечення безпеки значною мірою залежить від рівня реалізованості потенціалу саме цього компоненту. Умовою високого рівня такої реалізованості $є$ узгоджена діяльність, налагоджена взаємодія уповноважених суб'єктів щодо застосування визначених законом заходів, засобів, методів, інструментів та механізмів забезпечення безпеки. Важливим при цьому є ресурсне забезпечення їхньої діяльності (фінансове, матеріально-технічне, кадрове, інформаційне тощо), яке має бути необхідним і достатнім для реалізації ними своїх повноважень, своєчасного виявлення та повного усунення загроз і небезпек.

Результативний компонент опосередковує результат функціонування системи забезпечення безпеки і дозволяє встановити рівень іï дієвості, ефективності, а також визначити напрямки її подальшого вдосконалення.

Перелічені компоненти перебувають у тісних взаємозв'язках та взаємозалежностях і тільки в їх єдності й цілісності система здатна ефективно виконувати своє функціональне призначення - забезпечувати безпеку особи, суспільства і держави шляхом моніторингу, виявлення та ідентифікації, запобігання й припинення, мінімізації та нейтралізації дії загроз і небезпек.

Методологічний інструментарій системного підходу дозволяє розглядати систему забезпечення безпеки як відкриту й динамічну, тобто таку, що реагує на зміни у зовнішньому середовищі, а її функціонування і розвиток детермінується відповідними чинниками. Суттєвий вплив наразі здійснює державна політика щодо забезпечення безпеки як сукупність принципів та напрямів діяльності держави у цій сорері. Важливою $є$ роль чинників-викликів не тільки національного, але й глобального характеру. Чинники можуть впливати на систему як позитивно, стимулюючи їі прогресивний розвиток, так і негативно, гальмуючи його. Залежно від цього їх можливо поділяти на конструктивні й деструктивні (дестабілізуючі), до яких можна віднести економічні кризи, надзвичайні ситуації, недосконале законодавство, нормативно-правові основи діяльності суб'єктів забезпечення безпеки тощо.

Висновки і пропозиції. Таким чином, забезпечення безпеки, незалежно від її виду, вчені переважно розглядають як складноструктуроване явище. Узагальнену систему забезпечення безпеки можливо презентувати як 
взаємоузгоджену сукупність цільового, об'єктного, суб'єктно-організаційного та результативного компонентів. Цільовий компонент містить мету, завдання та принципи відповідної діяльності. Об'єктний компонент охоплює предмет - інтереси та цінності, які підлягають захисту, їх носіїв, загрози й небезпеки. Елементами суб'єктно-організаційного компоненту $€$ суб'єкти забезпечення безпеки, їх організаційне та ресурсне забезпечення. Результат функціонування системи забезпечення безпеки дозволяє встановити рівень ії дієвості та визначити напрямки ії подальшого удосконалення. Формування та розвиток системи забезпечення безпеки зумовлюють різноманітні чинники: внутрішні / зовнішні, національного / глобального характеру, конструктивні / деструктивні. Перспективним у напрямку дослідження $€$ використання даної моделі для побудови систем забезпечення безпеки конкретного виду.

\section{Список використаної літератури:}

1. Ліпкан В.А. Національна безпека України : навч. посіб. Київ : КНТ, 2009. 576 с.

2. Термін «безпека». URL : https://zakon.rada.gov. ua/laws/term/1742.

3. Словник української мови : Академічний тлумачний словник: в 11 томах. Т. 3. Київ, 1972. 725 с.

4. Нікітін Ю.В. Національна безпека України в сучасних умовах: ризики і фрактори впливу. Юридична наука. 2015. № 2. С. 141-147.

5. Антонов В.О. Конституційно-правові засади національної безпеки України : монографія / наук. ред. Ю.С. Шемшученко. Київ : ТАЛКОМ, 2017. 576 c.

6. Крук С.І. Інституційний розвиток державного управління у сфрері забезпечення національної безпеки України : автореф. дис. ... докт. наук з держ. управлін. : 25.00.05. Харків, 2019. 43 с.

7. Смолянюк В.Ф. Системні засади національної безпеки. Вісник Національного університету «Юридична академія України імені Ярослава Мудрого». 2018. № 2(37). С. 107-126.

8. Джумурат О.В. Методологічний підхід до формування системи економічної безпеки держави та роль ризиків у ньому. Вісник Академії мит- ної служби України. Серія: Економічні науки. 2012. № 1. С. 76-82.

9. Ситник Г.П., Завгородня С.П. Системний аналіз категоріально-понятійного апарату дослідження держаного управління економічною безпекою. Державне управління: теорія і практика. 2013. № 2. С. 82-89.

10.Козловський С.В., Жураківський Є.С. Теоретико-методологічні підходи до визначення категорії «економічна безпека» та складових економічної безпеки України. Економіка та держава. 2015. № 6. C. 37-42.

11. Калінеску Т. В., Недобега О. О., Альошкін В. С. Митна безпека : підручник. Сєверодонецьк : Вид-во СНУ ім. В. Даля, 2014. 336 с.

12.Левко М.М. Системний підхід до визначення ролі та місця митної безпеки у забезпеченні економічної безпеки держави. Науковий вісник НЛТУ України. 2016. Вип. 26.2. С. 95-103.

13.Левко М.М. Системний підхід до визначення ролі та місця митної безпеки у забезпеченні економічної безпеки держави. Науковий вісник Херсонського державного університету. Серія: Економічні науки. 2015. Вип. 15. Ч. 2. С. 16-20.

14.Гавловська Н.І., Осадчук О.В., Рудніченко Є.М. Вплив митних органів на економічну безпеку держави. Митна безпека. 2011. № 1-2. C. 52-56.

15.Новосад І.В. Митна безпека як важлива складова економічної безпеки держави. Свim фрінансів. 2015. № 2. С. 145-155.

16.Попівняк О.І. Щодо визначення поняття митної безпеки у теорії та законодавстві. Вісник НTКК «КПІ». Серія: Політологія. Соціологія. Право. 2018. Вип. 1(37). С. 87-91.

17.Пудрик Д.В. Поняття «митна безпека» в сучасній юридичній науці. Науковий вісник Міжнародного гуманітарного університету. Серія: Юриспруденція. 2016. № 24. С. 106-108.

18.Науково-практичний коментар до Митного кодексу України : у 3 т. / П.В. Пашко, В.Ю. Хомутиннік, Т.І. Єфименко та ін. Київ : ДННУ «Акад. фін. Управління», 2012. Т. 1. 428 с.

19. Ткаченко В.І., Смірнов ЄБ., Астахов О. О. Шляхи формування системи забезпечення національної безпеки. Збірник наукових праць Харківського університету Повітряних Сил. 2015. Вип. 2(43). С. 3-8.

\section{Ryabovol L. T. Security assurance as a scientific problem: implementation of a systematic approach to research}

The urgency of the topic is justified by the fact that at the present stage of world development security is an essential feature of the sovereignty of the state and at the same time a factor of its independence and autonomy, as well as an important area of activity of authorized entities. The purpose of the article is to analyze the positions of scientists on the structuring of the phenomena of different types of security assurance and to offer the author's vision of a generalized security system. It has been established that security assurance, regardless of its type, is mostly considered by scientists as a phenomenon with a complex structure. The necessity and expediency of implementing 
a systematic approach to the study of security assurance is due to the fact that it is a systematic approach to consider the phenomenon of security assurance most fully and comprehensively, in the unity and integrity of naturally located and interconnected components and elements, taking into account various factors. The generalized security assurance system is developed as a mutually agreed set of target, object, subject-organizational and effective components. The target component is presented as a set of the following elements - goals, objectives and principles of security assurance activities. Object component - as the unity of the subject (interests and values that need protection), the bearers of these interests and owners of values, as well as threats and dangers to these interests and values. The following elements of the subject-organizational component are singled out: subjects of providing a certain type of security assurance; methods, means, tools, mechanism of their activity; resource provision. It is revealed that the result of the functioning of the security assurance system allows to establish the level of its effectiveness and determine the directions of its further improvement and this is the value of the effective component of the studied system. It is stated that the formation and development of a security assurance system of a certain type is determined by various factors internal / external, national / global, constructive / destructive.

Key words: system, security, security assurance system, threat, danger, security assurance actors. 


\section{I. В. Слободенюк}

кандидат юридичних наук, докторант кафедри поліцейського права Національної академії внутрішніх справ

\section{АДМІНІСТРАТИВНІ ПОСЛУГИ В ДІЯЛЬНОСТІ СЕРВІСНИХ ЦЕНТРІВ МВС УКРАЇНИ: ПОНЯТТЯ, ВИДИ ТА КЛАСИФІКАЦІЯ}

Статтю присвячено з'ясуванню поняття та сутності адміністративних послуг у діяльності сервісних центрів МВС України, аналізу їх особливостей, та наведено пропозиції щодо їх систематизації. Встановлено, що адміністративні послуги в діяльності сервісних центрів МВС України є публічними послугами, які реалізуються за зверненням фрізичної чи юридичної особи відповідно до закону. Обгрунтовано, що надання адміністративних послуट у діяльності сервісних центрів МВС України є пріоритетним напрямком державної політики у сфері надання послуг. Окреслено, що суб'єктами звернення за адміністративними послугами в діяльності сервісних центрів МВС України є фрізичні та юридичні особи.

Розкрито, що сервісні центри МВС України надають як адміністративні, так і інші послуги, що загалом охоплюються терміном «сервісні». Акцентовано увагу на тому, що належність послуг до адміністративних визначається за такими критеріями: (1) повноваження органу щодо надання послуг визначається законом; (2) послуги надаються адміністративними органами шляхом реалізації владних повноважень; (3) послуги надаються за зверненням фрізичних та юридичних осіб; (4) результатом розәляду звернення є адміністративний акт; (5) надання послуг пов'язане із забезпеченням створення умов для реалізації фрізичними та юридичними особами прав, свобод $і$ законних інтересів. Встановлено, що система сервісних центрів, які підпорядковуються Міністерству внутрішніх справ України, надають як (1) платні, так і (2) безкоштовні адміністративні послуги.

Встановлено, що адміністративні послуги в діяльності сервісних центрів МВС України слід класифрікувати за такими критеріями: (1) за суб'єктом надання адміністративних послуг; (2) за видом суб'єкта звернення за адміністративною послугою; (3) за предметом звернення за адміністративною послугою; (4) за видами адміністративних послуг; (5) інфрормаційні послуги; (6) електронні послуги; (7) за юридичними наслідками; (8) за напрямком діяльності сервісних центрів; (9) за характером дій, змісту та обсягу процедурного характеру (основні та додаткові); (10) за видами адміністративних процедур у діяльності сервісних центрів МВС України. Зроблено висновок, що процес надання адміністративних послуг системою сервісних центрів МВС України характеризується чіткими та послідовними адміністративними процедурами, які мають специфрічні стадії, етапи та процесуальні дії.

Ключові слова: публічні послуги, сервісні послуги МВС України, адміністративні процедури, адміністративне право, адміністративно-правове регулювання.

Постановка проблеми. У положеннях Концепції поліпшення якості надання адміністративних послуг указано, що однією із серйозних проблем усіх органів влади в Україні $\epsilon$ відсутність необхідних умов для надання якісних послуг громадянам. Причина полягає в тому, що більшість посадовців не сприймають громадян як замовників послуг, а працюють згідно 3 адміністративно-бюрократичною системою, яка не орієнтована на громадянина, його потреби та очікування [1]. Крім того, однією із невирішених проблем управлінської діяльності $€$ проблема встановлення єдиного підходу до визначення сутності, змісту, поняття, критеріїв класифрікації адміністративних послуг в діяльності сервісних центрів МВС України.

Аналіз останніх публікацій. У юридичній науці окремим питанням адміністративних послуг приділяли увагу такі українські й зарубіжні вчені, як В.Б. Авер'янов, О.Ф. Андрійко, Д.М. Бахрах, Ю.П. Битяк, В.М. Гаращук, Т.О. Коломоєць, І.А. Гончарова [2], Є.О. Легеза [3], С.О. Шатрава [4], О.М. Шевчук [5]. Так, Ю.М. Жук вивчив основні напрямки діяльності центрів із надання адміністративних послуг в Україні [6], Д. Йосифович окреслив аспекти 
надання адміністративних послуг Міністерством внутрішніх справ України та Національною поліцією [7], А. Рибінська досліджувала правове регулювання надання адміністративних послуг Національною поліцією України [8], О. Мозговий вивчав підходи щодо дослідження адміністративних послуг у діяльності сервісних центрів MBC України [9]. Однак питання визначення сутності, змісту та поняття, а також критеріїв класифікації адміністративних послуг у діяльності сервісних центрів МВС України не з'ясовано в сучасних умовах реформування правоохоронних органів. Крім того, проблема вдосконалення діяльності щодо надання населенню якісних адміністративних послуг органами виконавчої влади взагалі та зокрема Міністерством внутрішніх справ набуває особливого значення в умовах євроінтеграційних процесів та реформ [7, с. 137]. Усе вищенаведене вказує на актуальність даного дослідження.

Мета статті - з'ясування сутності, ознак та критеріїв класифікації адміністративних послуг у діяльності сервісних центрів МBC України, аналіз їхніх особливостей, а також внесення пропозицій щодо їх систематизації.

Виклад основного матеріалу. Згідно з положеннями Закону України «Про адміністративні послуги» термін «адміністративна послуга» визначається як результат здійснення владних повноважень суб'єктом надання адміністративних послуг за заявою фізичної або юридичної особи, спрямований на набуття, зміну чи припинення прав та/або обов'язків такої особи відповідно до закону [10]. Відповідно до положень Концепції розвитку системи надання адміністративних послуг органами виконавчої влади дефініція «адміністративна послуга» визначена як результат здійснення владних повноважень уповноваженим суб'єктом, що відповідно до закону забезпечує юридичне оформлення умов реалізації фрізичними та юридичними особами прав, свобод і законних інтересів за їх заявою (видача дозволів (ліцензій), сертифікатів, посвідчень, проведення реєстрації тощо) [11].

Згідно з положеннями Закону України «Про адміністративні послуги» послуги бувають платні та безкоштовні [10]. У сфері діяльності сервісних центрів, які підпорядковуються Міністерству внутрішніх справ України, відповідно до поставлених завдань надаються як (1) платні, так і (2) безкоштовні адміністративні послуги. Крім того, сервісні центри МВС України удосконалюють процедури надання адміністративних послуг, у тому числі шляхом упровадження електронних сервісів, зокрема електронної черги, оплати вартості адміністративних послуг платіжними картками [12].

Належність послуг до адміністративних визначається за такими критеріями: (1) повноваження адміністративного органу щодо надання певного виду послуг визначається законом; (2) послуги надаються адміністративними органами шляхом реалізації владних повноважень; (3) послуги надаються за зверненням фізичних та юридичних осіб; (4) результатом розгляду звернення $€$ адміністративний акт, що має індивідуальний характер (паспорт, свідоцтво, ліцензія, дозвіл тощо); (5) надання послуг пов'язане із забезпеченням створення умов для реалізації фізичними та юридичними особами прав, свобод і законних інтересів. Контрольна діяльність адміністративного органу (перевірки, ревізії, інспектування тощо) не $€$ адміністративною послугою [11].

Немає єдиного визначення «адміністративні послуги в діяльності сервісних центрів МВC України». Спочатку з'ясуємо розуміння змісту правової конструкції «сервісна діяльність МВС України». Так, А.П. Рибінська вказує на визначення цієї конструкції як здійснення особливих владних повноважень Міністерством внутрішніх справ України з надання адміністративних та інших сервісних послуг через сервісні центри МBC України, спрямоване на набуття, зміну чи припинення прав та/або обов'язків суб'єкта звернення та/чи надання інформації під відомчим та громадським контролем [13, с. 4]. O.В. Карпенко пропонує сервісну діяльність органів державної влади розглядати в якості пріоритетного напрямку розвитку державного управління в Україні, сутність якої полягає в наданні управлінських послуг громадянам, які $\epsilon$ їх одержувачами - клієнтами держави (вигодонабувачами), а державні службовці й посадові особи органів місцевого самоврядування надавачами (виконавцями), що реалізують ці послуги від імені держави [14, с. 11]. О.О. Мозговий публічно-сервісну діяльність МВС України розглядає як: (1) окрему функцію сервісної держави, зміст якої полягає у зміні ідеології, форм та методів у роботі правоохоронних органів; (2) як одну із зовнішньо-орієнтованих функцій діяльності спеціально створеної державної інституції поряд із такими функціями, як регулятивна, контрольно-наглядова та правоохоронна; (3) основу для реалізації уповноваженим суб'єктом завдань та функцій держави щодо забезпечення прав і свобод людини, а також 
захист інтересів суспільства і держави, підтримання публічного порядку та безпеки, протидії злочинності; (4) якісне та доступне надання конкретним приватним особам адміністративних послуг у вигляді дозвільно-ліцензійних, реєстраційних та інших подібних дій у правоохоронній сорері $[15$, с. 40, 41]. Таким чином, надання адміністративних послуг у діяльності сервісних центрів МВС України $є$ пріоритетним напрямком державної політики у сфері правоохоронної діяльності та спрямоване на набуття, зміну чи припинення прав та/або обов'язків суб'єкта звернення. Суб'єктом звернення може бути фрізична або юридична особа.

Сервісні центри МВС України надають як адміністративні, так і інші послуги, що загалом охоплюються терміном «сервісні». Під іншими послугами слід розуміти: перевірку свідоцтва про реєстрацію авто; надання довідки про несудимість; здійснення технічного контролю; надання витягу з Єдиного державного реєстру MBC України; оформлення документів для виїзду за кордон; переобладнання транспортного засобу у спеціалізований учбовий; організацію з оцінки відповідності переобладнаних транспортних засобів [16].

Розглянемо термін «адміністративні послуги в діяльності сервісних центрів МВС України». Так, В.Б. Авер'янов вважає, що «адміністративні послуги» - це діяльність щодо задоволення певних потреб особи, яка здійснюється за зверненням (проханням) цієї особи [17, с. 453]. Із наукової позиції І.П. Голосніченко, не вся розпорядча діяльність державного органу, навіть якщо вона спрямована на реалізацію прав і свобод громадян, $\epsilon$ послугою. На думку автора, це пов'язано з тим, що основним призначенням всієї діяльності органів виконавчої влади та їх посадових осіб $€$ забезпечення прав і свобод людини [18, с. 8]. С.О. Шатрава під адміністративними послугами в діяльності органів Національної поліції розуміє урегульовану адміністративно-правовими нормами публічно-сервісну діяльність органів поліції, що здійснюється за зверненням фізичної чи юридичної особи, шляхом провадження передбачених законодавством послідовних дозвільних чи інших процедур, офріційним результатом якої $\epsilon$ індивідуальний адміністративний акт [19, с. 377, 378]. А.П. Рибінська вказує, що адміністративна послуга, з одного боку, $\epsilon$ публічною послугою, що передбачає реалізацію владних повноважень органами публічної адміністрації шляхом зверненням фізичної або юридичної особи відносно набуття, зміни чи припинення прав, обов'язків у порядку, визначеному законом. 3 іншого боку, адміністративна послуга - це окрема група адміністративних відносин, що реалізують права фрізичних та юридичних осіб за зверненням у різних сферах державного управління [13, с. 64]. Отже, адміністративні послуги в діяльності сервісних центрів МВС України $є$ публічними послугами, які реалізуються за зверненням фрізичної чи юридичної особи відповідно до закону. Результатом надання адміністративної послуги в діяльності сервісних центрів МВС України $€$ адміністративний акт. У результаті надання такого акта в суб'єктів звернення до сервісних центрів МВС України (фрізичних чи юридичних осіб) їхні права та обов'язки можуть виникати, припинятися чи обмежуватися. Процес надання адміністративних послуг у діяльності сервісних центрів МВС України характеризується чіткими та послідовнимиадміністративнимипроцедурами, які мають специфічні стадії, етапи та процесуальні дії.

Розглянемо критерії класифікації адміністративних послуг у наукових працях, а також наукові підходи до класифікації адміністративних послуг, що надаються через сервісні центри МBC України. Так, О.К. Туркова під час дослідження правової природи процедур надання адміністративних послуг звертає увагу на їх дуалістичний характер і досліджує у двох аспектах: (а) адміністративно-правовому, що виявляється у специфічній діяльності уповноважених осіб органів публічного управління із забезпечення надання адміністративних послуг суб'єктам звернення; (б) інфрормаційно-правовому, що простежується в умовах активного освоєння інформаційно-комунікаційних технологій у сфері державного управління, де пріоритетним визнається електронна форма надання таких послуг [20, с. 18].

Д. Йосифович всі адміністративні послуги, які надаються MBC України і Національною поліцією, класифрікує за такими підставами $[7$, c. 134,135$]$ :

1) за змістом конкретних адміністративних справ: (а) дозвільні (передбачають оформлення документів та видавання дозволів); (б) ліцензійні (видавання, переоформлення ліцензії); (в) реєстраційні; (г) експертні послуги; (д) документальне оформлення; (є) оформлення і видавання погоджувальних документів (висновків, довідок);

2) за юридичними наслідками: (а) надання прав (видавання дозволів, ліцензій, прийняття екзаменів на право водіння автотранспорт- 
них засобів із оформленням реєстраційних документів і документів на право керування транспортними засобами тощо); (б) припинення прав (скасування сертифіката на зброю, конструктивно схожих із нею виробів, набоїв, виробів піротехнічних побутового призначення та феєрверків; переоформлення зброї за місцем її обліку з одного власника на іншого; скасування ліцензій, дозволів; переоформлення ліцензії; видання негативних висновків); (в) обмеження прав (погодження проектів конструкцій транспортних засобів у частині дотримання вимог щодо: забезпечення безпеки дорожнього руху; огляду транспортних засобів, подальшої експлуатації транспортного засобу, ідентифікаційні номери кузова (рами) якого підроблені, стали непридатними або який розшукують правоохоронні органи іноземних держав);

3) за змістом та обсягом процедурних дій: (а) основні послуги (надаються за заявами з видаванням дозвільного, ліцензійного, погоджувального чи іншого документа); (б) супутні послуги (виготовлення копій документів, ламінування, фотографування, продаж канцелярських товарів, надання банківських послуг тощо), які можуть надаватися у приміщеннях, у яких розміщуються центри надання адміністративних послуг.

C.O. Шатрава пропонує адміністративні послуги, які надаються органами внутрішніх справ, класифікувати за такими критеріями: (1) спрямованість загроз національним інтересам, безпеці осіб, суспільства та держави; (2) рівень встановлення повноважень щодо надання дозвільних (адміністративних послуг) та правого регулювання процедури його надання; (3) залежно від виду дозвільної діяльності; (4) платність; (5) форма дозвільного документа, що видається [4, с. 107].

А.П. Рибінська пропонує класифікацію адміністративних послуг, що надаються через сервіси МBC України, за такими критеріями: (1) за суб'єктом надання послуг; (2) за суб'єктом звернення за послугою; (3) за предметом звернення для з'ясування їх реального ресурсу та ін. [13, с. 18]. Так, за суб'єктом надання послуг у системі МВС України виділяють: (1) підрозділи Національної поліції; (2) територіальні органи з надання сервісних послуг МВС України (регіональні та територіальні сервісні центри); (3) підрозділи експертної служби (НДЕКЦ); (4) підрозділи Державної міграційної служби України (ГУ у областях, районні відділи та сектори). За предметом звернення (послуги): (1) допуск водіїв до керування транспортними засобами; (2) допуск транспортних засобів до участі у дорожньому русі; (3) перевезення небезпечних вантажів; (4) придбання, оформлення, переоформлення, володіння, зберігання, носіння, перевезення, переміщення, виробництво зброї (вогнепальна, холодна, боєприпаси і т. д); (5) проведення судових експертиз, досліджень, оцінювань; надання відомостей з Єдиного державного реєстру МBC; (6) проведення перевірок, обстежень, охорони рухомих та нерухомих об'єктів [13, с. 66].

О.О. Мозговий публічні послуги, які надаються через сервісні центри МВС України, поділяє за такими критеріями [15, с. 62]:

1) дозвільні послуги (видача дозволів на встановлення та використання спеціальних та світлових сигнальних пристроїв; видача свідоцтв про погодження конструкції транспортного засобу щодо забезпечення безпеки дорожнього руху);

2) реєстраційні послуги (реєстрація та ведення Єдиного державного реєстру МBC; державна реєстрація (перереєстрація), зняття з обліку транспортних засобів, оформлення та видача реєстраційних документів; реєстр підприємств, установ, організацій та інших суб'єктів господарювання, які здійснюють торгівлю транспортними засобами та їх складовими частинами, що мають ідентифікаційні номери);

3) визнання певного статусу, права особи (видача довідки про притягнення до кримінальної відповідальності; видача довідки про відсутність (наявність) судимості, їїзняття, погашення);

4) інформаційні послуги (надання доступу до Єдиного державного реєстру MBC; ведення електронного реєстру підприємств, установ, організацій та інших суб'єктів господарювання, які ведуть оптову та роздрібну торгівлю транспортними засобами та їх складовими частинами, що мають ідентифікаційні номери; ведення реєстру суб'єктів здійснення обов'язкового технічного контролю);

5) послуги щодо надання висновків у сфері безпеки дорожнього руху (перевірка суб'єктів господарювання щодо відповідності матеріально-технічної бази та документації встановленим вимогам щодо діяльності, пов'язаної із реалізацією транспортних засобів з видачею акта (висновку); погодження проектів конструкцій, визначення технічних можливостей та умов переобладнання транспортних засобів з виданням відповідних свідоцтв та висновків).

Висновки і пропозиції. Виходячи з вищенаведеного, адміністративні послуги в діяльності сервісних центрів МВС України, на нашу думку, 
слід поділити за такими критеріями: (1) за суб'єктом надання адміністративних послуг; (2) за видом суб'єкта звернення за адміністративною послугою (фрізичні та юридичні особи); (3) за предметом звернення за адміністративною послугою; (4) за видами адміністративних послуг (дозвільні, реєстраційні, експертні послуги та ін.); (5) інформаційні послуги (ведення реєстру суб'єктів здійснення обов'язкового технічного контролю); (6) електронні послуги (онлайн-замовлення довідки про відсутність судимості; онлайн-запис до електронної черги; онлайн-надання відомостей з Єдиного державного реєстру транспортних засобів; онлайн-замовлення обміну та відновлення посвідчення водія; верифікація даних; електронний кабінет водія; замовлення індивідуального номерного знаку; онлайн-призначення належного користувача); (7) за юридичними наслідками (надання чи припинення прав та обов'язків, обмеження прав, визнання певного статусу особи); (8) за напрямком діяльності сервісних центрів (послуги щодо надання висновків у сфрері безпеки дорожнього руху); (9) за характером дій, змісту та обсягу процедурного характеру ((а) основні (надаються за заявами з видаванням дозвільного документу) та (б) додаткові (виготовлення копій документів, надання банківських послуг), що надаються у приміщеннях, де розміщені центри надання адміністративних послуг сервісних центрів МВС України; (10) за видами адміністративних процедур у діяльності сервісних центрів МВС України.

Адміністративні послуги в діяльності сервісних центрів МВС України є публічними послугами, які реалізуються за зверненням фрізичної чи юридичної особи відповідно до закону. Результатом надання адміністративної послуги в діяльності сервісних центрів МВС України $€$ адміністративний акт. У результаті надання такого акту в суб'єктів звернення до сервісних центрів МВС України (фрізичних чи юридичних осіб) їх права та обов'язки можуть виникати, припинятись чи обмежуватись. Процес надання адміністративних послуг у діяльності сервісних центрів МВС України характеризується чіткими та послідовними адміністративними процедурами, які мають специфрічні стадії, етапи та процесуальні дії.

\section{Список використаної літератури:}

1. Концепція поліпшення якості надання адміністративних послуг. URL : file:///C:/Users/1722/ Downloads/06150912_dod.pdf (дата звернення: 25.07.2020).
2. Гончарова І.А. Адміністративно-правовий аспект процедури надання адміністративних послуг : дис. ... канд. юрид. наук : 12.00.07. Херсон, 2017. 215 с.

3. Легеза Є.О. Адміністративні послуги, що надаються міліцією громадської безпеки : автореф. дис. канд. юрид. наук : спец. 12.00.07. Дніпропетровськ, 2011. 21 с.

4. Шатрава С.О. Адміністративні послуги в діяльності органів внутрішніх справ : поняття та класифікація. Jurnalul juridic national: teorie şi practică. 2015. № 6(16) . C. 104-107.

5. Шевчук О.М. Адміністративні процедури здійснення державного контролю за обігом наркотичних засобів: визначення поняття. Вчені записки Таврійського національного університету імені В.І. Вернадського. Серія: Юридичні науки. 2017. Т. 28(67). № 2. С. 42-46.

6. Жук Ю.М. Основні напрямки діяльності центрів із надання адміністративних послуг в Україні. Ефективність державного управління. 2016. № 48. URL : http://www.Ivivacademy.com/ vidavnitstvo_1/edu_48/fail/18.pdf (дата звернення.25.07.2020).

7. Йосифович Д. Надання адміністративних послуг Міністерством внутрішніх справ України та Національною поліцією. Вісник Національного університету «Львівська політехніка». Серія: Юридичні науки. 2017. № 876(15). С. 131-137.

8. Рибінська А.П. Правове регулювання надання адміністративних послуг Національною поліцією України. «Правові системи». Науково-практичний електронний журнал. 2017. № 3/4. С. 63-72.

9. Мозговий О.О. Сучасні підходи щодо дослідження адміністративних послуг в діяльності сервісних центрів МВС України. Jurnalul juridic national: teorie şi practică. 2018. № 5(33). c. 77-79.

10.Про адміністративні послуги : Закон України від 06.09.2012 № 5203-VI. Відомості Верховної Ради. 2013. № 32. Ст. 409.

11.Концепція розвитку системи надання адміністративних послуг органами виконавчої влади: розпорядження Кабінету Міністрів України від 15.02. 2006 р. № 90-p. URL : https://www.kmu.gov.ua/npas/29277890 (дата звернення: 25.07.2020).

12.Рибінська А.П. Адміністративно-правове забезпечення діяльності з надання сервісних послуг МВC : дисерт. на здоб. ... канд. юрид. наук : 12.00.07. Державний науково-дослідний інститут Міністерства внутрішніх справ України. Київ, 2019. 199 с.

13.Про затвердження Положення про Головний сервісний центр МBC (у редакції наказу Міністерства внутрішніх справ 
України від 26.11.2018 р. № 955) від 07.11.2015 № 1393. URL : https://hsc.gov.ua/ wp-content/uploads/2019/02/PolozhennyaGSTS.p (дата звернення: 25.07.2020).

14.Карпенко О.В. Механізм формування та реалізації сервісно-орієнтованої державної політики в Україні : дис. ... докт. наук з держ. управл. : 25.00.02. Київ, 2016. 466 с.

15.Мозговий О.О. Адміністративно-правові засади діяльності сервісних центрів МВC України : дисерт на ... к.ю.н. спец. : 12.00.07. Науково-дослідний інститут публічного права, Київ, 2019. 229 с.

16.Адміністративні послуги сервісних центрів. URL : https://hsc.gov.ua/poslugi/poslugi-shho- nadayutsya-servisnimi-tsentram/ (дата зверненя: 25.07.2020).

17.Адміністративне право України. Акад. курс : підручн. в 2 т. Т. 1: Заг. част. / голов. редкол. : Авер'янов В.Б. Київ : Юридична думка, 2004. 584 с.

18.Адміністративне право України : основні поняття : навч. посіб. / за заг. І.П. Голосніченка. Київ : ГАН, 2005. 232 с.

19.Шатрава С.О. Теорія і практика запобігання корупції в органах Національної поліції України: адміністративно-правове дослідження : монографія. Харків : Диса плюс, 2016. 439 с.

20. Туркова О.К. Правова природа процедур надання адміністративних послуг в Україні : дис. ... канд. юрид. наук : 12.00.07. Харків, 2017. 238 с.

\section{Slobodeniuk I. V. Administrative services in operation service centers of the MIA of Ukraine: concept, types and classification}

The article is devoted to clarification of the concept and essence of administrative services in the activities of service centers of the Ministry of Internal Affairs of Ukraine, analysis of their features and proposals for their systematization. It was established that administrative services in the activities of the service centers of the Ministry of Internal Affairs of Ukraine are public services that are implemented when an individual or legal entity applies in accordance with the law. It is substantiated that the provision of administrative services in the activities of the service centers of the Ministry of Internal Affairs of Ukraine is a priority direction of the state policy in the field of law enforcement. It was determined that the subjects of appeal for administrative services in the activities of the service centers of the Ministry of Internal Affairs of Ukraine are individuals and legal entities.

It is revealed that the service centers of the Ministry of Internal Affairs of Ukraine provide both administrative and other services, which are generally covered by the term "service". Attention is focused on the fact that the belonging of services to administrative is determined by the following criteria: (1) the authority of the body to provide services is determined by law; (2) services are provided by administrative bodies through the exercise of powers of authority; (3) services are provided when applying to individuals and legal entities; (4) the result of consideration of the appeal is an administrative act; (5) the provision of services is associated with ensuring the creation of conditions for the exercise by individuals and legal entities of their rights, freedoms and legal interests. It was established that the system of service centers that are subordinate to the Ministry of Internal Affairs of Ukraine provide both (1) paid and (2) free administrative services.

It has been established that administrative services in the activities of service centers of the Ministry of Internal Affairs of Ukraine should be classified according to the following criteria: (1) by the subject of the provision of administrative services; (2) by type of the subject of administrative services; (3) on the subject of applying for an administrative service; (4) by type of administrative services; (5) information services; (6) electronic services; (7) on legal consequences; (8) in the direction of activity of service centers; (9) by the nature of actions, content and scope of a procedural nature (basic and additional); (10) by types of administrative procedures in the activities of service centers of the Ministry of Internal Affairs of Ukraine. It is concluded that the process of providing administrative services by the system of service centers of the Ministry of Internal Affairs of Ukraine is characterized by clear and consistent administrative procedures that have specific stages, phases and procedural actions.

Key words: public services, services of the Ministry of Internal Affairs of Ukraine, administrative procedures, administrative law, administrative and legal regulation. 


\section{ДОБРОВІЛЬНІ МЕТОДИ МОБІЛІЗАЦІЇ КОШТІВ ДО ПУБЛІЧНИХ ФОНДІВ: ФІНАНСОВО-ПРАВОВИЙ АСПЕКТ}

У науковій літературі основна увага приділяється дослідженню питань правового регулювання справляння обов'язкових платежів до публічних фондів коштів. Поряд із податками, зборами, митами, платами держави та інші публічні суб'єкти застосовують і інші методи мобілізації коштів до публічних фондів. Проте комплексне дослідження, присвячене правовому регулюванню добровільного методу мобілізації коштів до публічних фрондів в Україні, відсутнє. На основі здобутків науки фрінансового права в роботі приділено увагу висвітленню правового регулювання таких методів добровільного залучення коштів державою та місцевими органами до публічних фондів коштів, як: державний місцевий кредит (запозичення), державні/місцеві гарантії; державні лотереї; розміщення коштів на рахунках банків державного сектору (як депозитних, так і поточних), НБУ; благодійні внески, гранти, дарунки; державне кредитування. Встановлено, що, не дивлячись на заборону щодо розміщення бюджетних коштів на позабюджетних рахунках, деякі суб'єкти наділені правом розміщення частини таких коштів на вкладних (депозитних) рахунках, при цьому відсотки, нараховані на такі рахунки, $є$ джерелом фрормування загального фронду бюджету або відповідно зараховуються на спеціальний реєстраційний рахунок у Казначействі. Встановлено суб'єктів, які, крім права на розміщення публічних коштів на поточних рахунках у банках, набули права на нарахування відсотків на залишок коштів на таких рахунках. Такі відсотки зараховуються на спеціальний реєстраційний рахунок в органі Казначейства. Зроблено висновок, що в даному випадку має місце добровільний метод мобілізації коштів до публічних фрондів. Досліджено правовий механізм участі держави та місцевих органів у відносинах державного/місцевого кредиту, державних/місцевих гарантій. Приділено увагу таким методам мобілізації коштів, як державна лотерея та благодійні внески, гранти і дарунки. Обгрунтовано, що державне кредитування (кредитування бюджету) можна віднести до добровільного методу мобілізації коштів до публічних фрондів. Вироблено пропозиції вдосконалення законодавства в зазначеній сфрері.

Ключові слова: правові методи мобілізації коштів, добровільний метод мобілізації коштів, державний місцевий кредит (запозичення), державні/місцеві гарантії, державні лотереї, розміщення коштів на рахунках банків державного сектору, благодійні внески, гранти, дарунки, державне кредитування.

Постановка проблеми. Для забезпечення реалізації суспільного інтересу державі та органам місцевого самоврядування завжди потрібні кошти. Якщо йдеться про залучення коштів до публічних фондів, увага приділяється правовому регулюванню обов'язкового методу мобілізації. Звичайно, він більш відомий, оскільки викликає супротив із боку осіб, на яких покладається обов'язок перерахувати відповідні суми коштів до публічних фондів. Обов'язковий метод мобілізації коштів до публічних фондів реалізується шляхом справляння податків, зборів, єдиного соціального внеску, державного

() Сударенко О. В., 2020 мита, інших обов'язкових платежів відповідно до закону. Інша ситуація щодо добровільного методу мобілізації. Як правило, нефахівці зазначають, що він полягає у сплаті благодійних внесків, добровільних пожертвувань. Що ж до інших способів добровільного методу мобілізації коштів до публічних фондів, то тут навіть у науці не завжди визначають всі добровільні методи мобілізації, згадуючи тільки державні/місцеві запозичення, добровільні внески, лотереї.

Аналіз останніх наукових досліджень. Щодо наукових робіт, присвячених правовому регулюванню добровільного методу мобілізації, 
то вони відсутні. Водночас методам мобілізації коштів до публічних фрондів присвячують певну увагу в роботах щодо правового регулювання фінансової діяльності держави та органів місцевого самоврядування.

Наукову основу нашого дослідження становлять праці провідних науковців у сфрері фрінансового права: Воронової Л.К., Заверухи І.Б., Кучерявенка М.П., Музики-Стесранчук О.А., Ніщимної С.О., Орлюк О.П., Пацурківського П.С., Пришви Н.Ю., Худякова О.І. та ін. Користуючись здобутками науки фрінансового права, в роботі буде приділено увагу висвітленню правового регулювання таких способів добровільного залучення коштів державою та місцевими органами до публічних фондів коштів, як: державний/місцевий кредит (запозичення), державні лотереї, залучення публічних коштів на рахунки у банки державного сектору, добровільні внески, державне кредитування.

Мета статті полягає в дослідженні правового регулювання добровільних методів мобілізації коштів, які застосовують держава та місцеві органи для залучення коштів до публічних фондів з метою виконання їх завдань та функцій, а також виробленні пропозицій вдосконалення законодавства в зазначеній сфері.

Виклад основного матеріалу. У перших підручниках 3 «Фінансового права» було зазначено, що «метод добровільної мобілізації грошових коштів включає в себе проведення лотерей, випуск державою облігацій, інших цінних паперів, добровільні внески громадян і т. п.» [1, с. 20]. У подальшому зазначається, що «метод добровільної мобілізації передбачає переважно диспозитивні способи забезпечення фрінансових надходжень, механізми кредитування (вклади населення, придбавання державних цінних паперів, лотерейних білетів тощо» [2, с. 15 ; 3, с. 47], «... добровільні платежі, випускаючи і реалізуючи державні і муніципальні цінні папери юридичним і фрізичним особам, приймаючи доброчинні внески на користь держави від іноземних і українських юридичних і фрізичних осіб» [4, с. 18-19; 5, с. 18].

О.А. Музика-Стефранчук зазначає, що добровільний метод акумулювання (мобілізації, фрормування) фондів коштів - «...(проведення лотерей, випуск цінних паперів, залучення добровільних внесків юридичних і фрізичних осіб)» [6, с. 21]. «За методами вилучення коштів доходи місцевих бюджетів поділяються на такі, внесення яких відбувається добровільно (гранти, пожертви, дарунки)...» [7, с. 89]. Отже, йдеться тільки про три методи мобілізації коштів.
O.I. Худяков писав, що «держава, виявляючи гнучкість, використовує різні прийоми та способи мобілізації й розподілу коштів, які їй потрібні. Так, формування доходної частини бюджету здійснюється державою як шляхом примусового й безоплатного вилучення коштів (зокрема, за допомогою обов'язкових платежів та податків), так і шляхом добровільного, поворотного їх залучення (за допомогою, зокрема, державних запозичень)» [8, с. 114]. До добровільного методу мобілізації фондів коштів він відносив лотерею, вклади коштів на вкладні (депозитні) рахунки [8, с. 116, 149-157]. Hayковець зазначав, що сутність ощадної справи, яка здійснюється державними установами (банками, ощадкасами тощо), - це використання коштів вкладників в якості фрінансових ресурсів держави [8, с. 154]. До ознак, які відмежовують цивільно-правовий договір вкладного (депозитного рахунку) від фрінансово-правового, на думку О.І. Худякова, належать: умови договору вкладу визначені державою (у формі нормативного акту); умови вкладу можуть бути змінені в односторонньому порядку; кошти, отримані шляхом вкладу, не належать до власності банку (вони набувають форму державної власності та використовуються ним за вказівкою держави та в ії інтересах); у договорі з Ощадбанком збереження та повернення коштів гарантується державою [8, с. 156].

Отже, науковий інтерес становить 3'ясування питання чи застосовується даний вид добровільного методу мобілізації коштів у сучасній Україні. Обов'язок щодо збереження коштів на поточних рахунках стосується тільки юридичних осіб. Обов'язку щодо збереження коштів на вкладних (депозитних) рахунках немає. Отже, юридичні та фрізичні особи, за загальним правилом, самостійно вирішують, чи зберігати їм кошти на вкладних (депозитних рахунках) та в яких банках. В Україні існує заборона щодо розміщення публічних коштів, зокрема бюджетних (включаючи власні надходження бюджетних установ), на позабюджетних рахунках [9]. Кошти позабюджетних цільових фондів також повинні розміщуватися на єдиному казначейському рахунку. Разом із тим починаючи з 2011 певні суб'єкти набули права на розміщення тимчасово вільних коштів бюджету на основі фрінансово-правового договору на рахунках банків державного сектору (Голова Боргового агентства за погодженням $з$ Міністром фінансів України щодо коштів державного бюджету України; керівник місцевого фрінансового органу за рішенням від- 
повідної місцевої ради щодо коштів місцевого бюджету). Відсотки, нараховані на такі рахунки, зараховуються до доходів загального фонду відповідного бюджету [9; 10; 11]. При цьому у 2019 призупинено право на розміщення коштів загального фонду місцевого бюджету на рахунках банків державного сектору. Як альтернативу залишено право на придбання облігацій внутрішнього державного боргу [12]. У подальшому правом на розміщення коштів на вкладних (депозитних) рахунках у банках державного сектору були наділені заклади професійної (професійно-технічної), фрахової передвищої та вищої освіти. Відсотки, нараховані на вкладний (депозитний) рахунок такого суб'єкта, зараховуються на спеціальний реєстраційний рахунок закладу, відкритий в органі Казначейства [13].

Особливу увагу слід звернути на право державних i комунальних закладів вищої освіти, державних наукових установ, державних і комунальних закладів культури щодо розміщення коштів (власних надходжень, отриманих як плата за послуги, що надаються ними згідно з основною діяльністю, благодійні внески, гранти) на поточних рахунках у банках державного сектору [9; 14]. За даною програмою держава наділила суб'єктів також правом на отримання відсотків на залишок коштів на поточних рахунках. Проте такі відсотки зараховуються на спеціальний реєстраційний рахунок в органі Казначейства, відкритий такому розпорядникові бюджетних коштів. Вважаємо, що в даному випадку йдеться також про добровільний метод мобілізації фондів коштів. Правом на розміщення коштів на поточних рахунках сьогодні наділений і місцевий фрінансовий орган за рішенням Верховної Ради АРК, відповідної місцевої ради під час виконання місцевих бюджетів щодо обслуговування бюджетних коштів у частині бюджету розвитку, та розпорядники і одержувачі бюджетних коштів щодо власних надходжень бюджетних установ [9, абзаци 3-4 ч. 2 ст. 78; 15]. Вважаємо, що зазначених суб'єктів також слід наділити правом на отримання відсотків на залишок коштів на поточному рахунку із спрямуванням таких відсотків на спеціальний реєстраційний рахунок, відкритий в органі Казначейства такому суб'єктові. Також держава наділила правом Фонд гарантування вкладів фрізичних осіб отримувати проценти, нараховані НБУ за залишками коштів на рахунках Фонду, відкритих в НБУ [16, ст. 19].
Одним із шляхів, за допомогою яких держава та місцеві органи залучають кошти на виконання суспільного інтересу на засадах добровільності, строковості, поворотності та оплатності, $є$ державний і місцевим кредит. Саме держава/місцевий орган, як суб'єкт, який представляє публічний фрінансовий інтерес, позичаючи кошти в юридичних і фрізичних осіб, в односторонньому порядку встановлюють умови цих відносин, не даючи суб'єктам, які виявили бажання придбати цінні папери, ніяких прав, крім права на купівлю цих цінних паперів і одержання в установлений строк відсотків, розмір яких установлено в Постанові Уряду України про випуск цього виду паперів, а також одержати номінальну вартість, незалежно від курсової вартості, за якою вони куплені, після закінчення строку цих відносин. Друга сторона правовідносин - кредитор, вступаючи у відносини добровільно, повністю підкоряється цим умовам, тимчасово віддаючи кошти в розпорядження держави/місцевого органу. Вона може і не отримати назад витрачені на придбання цінних паперів кошти, якщо держава/місцевий орган змінить умови запозичення [4, с. 307].

Право на здійснення державних запозичень належить державі в особі Голови Боргового агентства України. При цьому реалізувати відповідне право Боргове агентство може за дорученням Уряду України в межах та на умовах здійснення таких запозичень, передбачених законом про Державний бюджет України. Кредити (позики) від іноземних держав, іноземних фрінансових установ і міжнародних фрінансових організацій для реалізації інвестиційних проектів залучаються державою на підставі міжнародних договорів України і належать до державних зовнішніх запозичень. У правовідносинах щодо використання коштів міжнародних фрондів на території України беруть участь як самостійні суб'єкти - Уряд України (Боргове агентство України) та Національний банк України [9; 17; 18, п. 13 ч. 1 ст. 7 , ст. ст. 43, 47, 48]. При цьому НБУ не має права купувати на первинному ринку цінні папери, емітовані Урядом України, державною установою, іншою юридичною особою, майно якої перебуває в державній власності. Під законодавчу заборону підпадає і надання НБУ кредитів у національній та іноземній валюті, як прямо, так і опосередковано через державну установу, іншу юридичну особу, майно якої перебуває в державній власності, на фрінансування витрат Державного бюджету України [18, ст. 54]. Зазначені суб'єкти забезпечують участь України 
в міжнародних фінансово-кредитних відносинах, як публічних, так і приватних. I тому варто звернути увагу на розподіл, запропонований Світовим Банком, за яким усі відносини, що здійснюються через МБРР та МАР, є за своєю природою публічними. Відносини, що здійснюються через МФК та БАГІ, - приватними [19, с. 281].

Право на здійснення місцевих запозичень у межах, визначених рішенням про місцевий бюджет, з урахуванням ст. 74 Бюджетного кодексу належить Автономній Республіці Крим, обласній раді, територіальній громаді міста в особі керівника місцевого фрінансового органу за дорученням відповідної ради. При цьому здійснювати місцеві внутрішні запозичення (за винятком випадків, передбачених статтею 73 БК) належить Верховній Раді АРК, обласним та міським радам. У відносинах місцевих зовнішніх запозичень, які можуть здійснюватись шляхом отримання кредитів (позик) від міжнародних фінансових організацій, чітко визначено суб'єктів правовідносин: кредит надає міжнародна фінансова організація, боржник-Верховна Рада АРК, обласні ради та всі міські ради. Інші місцеві зовнішні запозичення можуть здійснювати лише Верховна Рада АРК, Київська, Севастопольська міські ради, міські ради міст обласного значення. Отже, збільшено коло суб'єктів надання кредитів (позик), проте зменшено суб'єктів, які мають право на отримання. Слід зазначити, що обласні ради набули права брати участь у відносинах місцевих запозичень тільки з 2020, тому відповідних змін потребує ст. 9 Закону України «Про цінні папери та фондовий ринок». Суб'єкти, які мають право отримувати державний/місцевий кредит, наділені також правом бути учасником державних/місцевих гарантій, які також $є$ прикладом добровільного методу мобілізації коштів до відповідного бюджету. За надання таких гарантій справляється плата, яка належить до надходжень бюджету [9, ст. 17].

Крім держави та місцевих рад, правом випуску облігацій наділено ще Фонд гарантування вкладів фрізичних осіб [20, ст. 8-2]. Облігації Фонду розміщуються виключно на внутрішньому фондовому ринку, в національній валюті і підтверджують його зобов'язання щодо відшкодування пред'явникам цих облігацій їх номінальної вартості з виплатою доходу відповідно до умов розміщення облігацій. Отримані від розміщення облігацій кошти Фонд використовує за цільовим призначенням, визначеним Законом України «Про систему гарантування вкладів фрізичних осіб».
Добровільним методом мобілізації коштів, який широко використовується в інших державах та Україні, є надходження від лотерей. «Лотерея $€$ важливим джерелом поповнення Державного бюджету та благодійних фондів, діяльність яких спрямована на розвиток фізичної культури та спорту, підтримку осіб з інвалідністю, дитячих закладів, культури та національного надбання...» [21, с. 86]. Участь у лотереї $\epsilon$ цілком добровільною, як із боку операторів державних лотерей, які повинні отримати ліцензію на випуск і проведення лотерей (кошти $\epsilon$ джерелом формування державного та місцевих бюджетів), розповсюджувачів державної лотереї, так і з боку осіб, які придбавають лотерейні білети. Умови проведення державної лотереї не можуть містити положення, за якими витрати на її організацію, а також виплати призового (виграшного) фонду здійснюються за рахунок Державного бюджету України, місцевих бюджетів, цільових державних фондів або кошторисів на утримання органів державного управління чи заснованих ними установ, організацій і підприємств [22, ч. 9 ст. 5].

До добровільного методу мобілізації належить ще метод, який «реалізується у вигляді пожертв, дарувань, здійснення іншої благодійної діяльності громадянами та юридичними особами на користь держави, де в загальному обсязі державних доходів посідає незначне місце» [23]. Поряд із цим в Україні широко використовуються гранти, надходження в рамках програм допомоги ЄС, урядів іноземних держав, міжнародних організацій, донорських установ до бюджетів усіх рівнів. Державні цільові публічні фонди також наділені правом на одержання благодійних внесків, грантів, технічної допомоги у грошовій або негрошовій формі, в тому числі від іноземних осіб.

Водночас виникає питання, чи можна відносини державного кредитування (кредитування бюджету) визначити як добровільний метод мобілізації коштів. Первинним у даному випадку $\epsilon$ виділення коштів із відповідного публічного фонду, зокрема бюджету, певним суб'єктам на умовах строковості, як правило оплатності та поворотності, та на певну мету (як правило, на виконання однієї із функцій держави чи місцевого органу). Суб'єкти отримання кредитування беруть участь у цих відносинах на добровільних засадах, повинні повернути суму кредитування чи його частину до відповідного публічного фонду, залежно від програми виділення коштів. Кошти до публічного фонду поверта- 
ються частково через певний проміжок часу та акумулюються у загальному чи спеціальному фонді бюджету. Разом із тим кошти фізичних та юридичних осіб, яким надається таке кредитування залучаються до обігу (використовуються як ресурси держави). Отже, на виконання відповідної функції держави/місцевого органу направляються спільно кошти держави/місцевого органу, фізичних та юридичних осіб, яким надається відповідне кредитування, а за певних умов ще й кошти банку (зокрема, програми «Доступне житло»). На нашу думку, відносини державного кредитування є добровільним методом мобілізації коштів до публічних фондів.

Висновки і пропозиції. На сучасному етапі розвитку суспільних відносин в Україні держава та місцеві органи поряд із обов'язковим методом мобілізації коштів до публічних фондів широко використовують і добровільні методи мобілізації. До таких методів належать державний/місцевий кредит (запозичення), державні/ місцеві гарантії; розміщення коштів на рахунках банків державного сектору (як депозитних, так і поточних), НБУ; проведення державних лотерей; благодійні внески, гранти, дарунки; державне кредитування.

Вважаємо, що місцевий фінансовий орган розпорядників (одержувачів) бюджетних коштів, які мають право на розміщення коштів на поточних рахунках, також слід наділити правом на отримання відсотків на залишок коштів на поточному рахунку із спрямуванням таких відсотків на спеціальний реєстраційний рахунок, відкритий в органі Казначейства такому суб'єктові.

Обласні ради набули права брати участь у відносинах місцевих запозичень тільки з 2020, тому відповідних змін потребує ст. 9 Закону України «Про цінні папери та фондовий ринок».

\section{Список використаної літератури:}

1. Фінансове право : підручник / Алісов Є.О., Воронова Л.К., Кадькаленко С.Т. та ін. ; Керівник авт. колективу і відп. ред. Л.К. Воронова. Харків : Фірма «Консум», 1998. 496 с.

2. Воронова Л.К., Кучерявенко Н.П. Финансовое право : учебное пособие для студентов юридических вузов и факультетов. Харьков : Легас, 2003. $360 \mathrm{c}$.

3. Фінансове право України : навч. посібник / Л.К. Воронова, М.П. Кучерявенко, Н.Ю. Пришва та ін. Київ : Правова єдність, 2009. 395 с.

4. Воронова Л.К. Фінансове право України : підручник. Київ : Прецедент, Моя книга, 2006. 448 с.

5. Фінансове право України : навч. посібник / Л.К. Воронова, Н.Ю. Пришва, Н.Я. Якимчук та ін. / за заг. ред. проф. Пришви Н.Ю. Київ : Видавництво Ліра-К, 2018. 376 с.

6. Музика-Стефанчук О.А. Фінансове право : навч. посіб. Київ : Ін Юре, 2018. 348 с.

7. Музика О.А. Доходи місцевих бюджетів за українським законодавством : монографрія. Київ: Атіка, 2004. 344 с.

8. Худяков А.И. Избранные труды по фринансовому праву / Сост. М.К. Сулейменов, Е.В. Порохов, М.В. Карасева, А.Т. Шаукенов. Санкт-Петербург : Издательство «Юридический центр-Пресс», 2010. 472 с.

9. Бюджетний кодекс України, 08.07.2010 № 2456-VI. URL : https://zakon.rada.gov.ua/laws/ show/2456-17\#Text.

10.Про затвердження порядків розміщення тимчасово вільних коштів єдиного казначейського рахунка шляхом придбання облігацій внутрішньої державної позики і розміщення тимчасово вільних коштів єдиного казначейського рахунка та коштів валютних рахунків державного бюджету на депозитних рахунках: Постанова Кабінету Міністрів України від 19.01.2011 № 65. Офіційний вісник України. 2011. № 8.

11. Про затвердження Порядку розміщення тимчасово вільних коштів місцевих бюджетів на вкладних (депозитних) рахунках у банках : Постанова Кабінету Міністрів України від 12.11.2011 № 6. Урядовий кур'єр. 2011. № 14.

12.Альтернатива депозитам: як громадам ефективно використати тимчасово вільні кошти місцевих бюджетів. URL : https://decentralization. gov.ua/news/10751.

13.Про затвердження Порядку розміщення вищими і професійно-технічними навчальними закладами на вкладних (депозитних) рахунках в установах банків державного сектору економіки тимчасово вільних бюджетних коштів, отриманих за надання платних послуг : Постанова Кабінету Міністрів України від 26.08.2015 № 657. Офіційний вісник України. 2015. № 72.

14.Питання власних надходжень державних i комунальних вищих навчальних закладів, наукових установ та закладів культури: Постанова Кабінету Міністрів України від 02.09.2015 №719.URL:https://zakon.rada.gov.ua/laws/show/ 719-2015-п\#n10.

15.Про затвердження Порядку обслуговування коштів місцевих бюджетів у частині бюджету розвитку та власних надходжень бюджетних установ в установах банків державного сектору : Постанова Кабінету Міністрів України від 14.05.2015 р. № 378. Урядовий кур’єр. 2015. № 102.

16.Про систему гарантування вкладів фрізичних осіб : Закон України від 23.02.2012 № 4452-VI. URL : https://zakon.rada.gov.ua/laws/ show/4452-17\#Text. 
17.Про вступ України до Міжнародного валютного фонду, Міжнародного банку реконструкції та розвитку, Міжнародної фрінансової корпорації, Міжнародної асоціації розвитку та Багатостороннього агентства по гарантіях інвестицій : Закон України від 03.06.1992 № 2402-XII. BBP. 1992. № 33. Ст. 474.

18.Про Національний банк України : Закон України від 20.05.1999 № 679-XIV. URL : https://zakon.rada.gov.ua/laws/show/679-14\#Text.

19.Грабинский М.І. Сучасний погляд на суб'єктів міжнародних економічних відносин. Науковий вісник публічного та приватного права. 2016. Випуск 4. С. 277-281. URL : http:inter.Inu.edu.ua/ wp-сщntent/uploads/2017/09/65/pdf.

20.Про цінні папери та фондовий ринок : Закон України від 23.02.2006 № 3480-IV. URL : https://zakon.rada.gov.ua/laws/show/ 3480-15\#Text.

21. Туманов В. Правове регулювання провадження господарської діяльності з випуску та проведення лотерей у країнах Європейського Союзу. Підприємництво, господарство і право. 2009. № 11. C. 86-89. URL : http://pgp-journal.kiev.ua/ archive/2009/11_2009.pdf.

22.Про державні лотереї в Україні : Закон України від 06.09.2012 № 5204-VI. URL : https://zakon.rada.gov.ua/laws/show/ 5204-17\#Text.

23.Трубіна М.В. Фінансова діяльність держави: підходи до видозмінення наукових аспектів пізнання. Фінансове право. 2014. № 4. C. 13-16. URL : http://ndi-fp.nusta.com.ua/files/ doc/ФП\%204.pdf.

\section{Sudarenko O. V. Voluntary money mobilization methods to public funds: financial and legal aspect}

The scientific literature at this time mainly focuses on how making mandatory payments to public funds is regulated by law. Along with taxes, fees, duties, governmental mandatory payments, public entities use other methods of collecting money. However, a comprehensive study of legal regulation on how funds can be voluntarily mobilized to public funds in Ukraine is absent. In this work, attention is paid to the law which is used by municipalities and state government in order to collect money to public funds such as state municipal credit (borrowing), state / municipal guarantees; state lotteries; placement of funds to public sector banks accounts (both saving and chequing) or to National Bank of Ukraine; charitable contributions, grants, gifts; state credits. It is established that despite the ban on the allocation of budget funds on extra-budgetary accounts, some entities still have the right to place a part of such funds on saving accounts. However, the interest accrued on these accounts is a source of formation of the general budget fund or shall be directed to a Treasury special registration account. It is also identified entities, who in addition to the right to place and hold public funds in chequing accounts at banks have acquired the right to accrual and own interest. Such interest shall be directed to a Treasury special registration account. It is concluded that such activities constitute a voluntary money mobilization method to public funds. The legal mechanism is investigated on how the state and local authorities are participating in state / municipal borrowing, state / municipal guarantees. Attention is paid to such methods of fundraising as a state lottery and charitable contributions, grants and gifts. It is substantiated that public lending (budget lending) can be attributed to the voluntary method of public funds mobilization. Proposals for improving the legislation in this area have been developed.

Key words: legal methods of money mobilization, voluntary method of fundraising, state local credit (borrowing), state / municipal guarantees, state lotteries, placement of funds on accounts of public sector banks, charitable contributions, grants, gifts, state lending. 


\section{C. Фedopimes}

здобувач кафедри адміністративного та митного права Університету митної справи та фрінансів

\section{ДІЯЛЬНІСТЬ ЦЕНТРІВ НАДАННЯ АДМІНІСТРАТИВНИХ ПОСЛУГ: ПРОБЛЕМНІ ПИТАННЯ ТА ШЛЯХИ ЇХ ВИРІШЕННЯ}

У статті висвітлюється діяльність центрів надання адміністративних послуг: проблемні питання та шляхи їх вирішення. Серед проблем в діяльності центрів надання адміністративних послуг можна виділити, зокрема: складність процедур надання адміністративних послуг, коли замовники послуг задля їх отримання повинні збирати значну кількість документів, проміжних рішень та погоджень по різних органах влади, які частіше за все розташовані у різних місиях населених пунктів, вистоюючи підчас великі черги в адміністративних органах та очікуючи різні терміни на їх підготовку; відсутність або обмежений доступ до інфрормації про процедури надання адміністративних послуг; затягування посадовими особами органів місцевого самоврядування та виконавчої влади термінів надання багатьох адміністративних послуг; незручний режим роботи органів влади, що надають такі послуги, який частіше за все співпадає зі звичайним графріком роботи більшості громадян та викликає певні незручності в першу чергу для фрізичних осіб, які змушені звертатись за отриманням адміністративних послуг; відсутність альтернативних способів звернення до адміністративних органів за послугами, що ставить у пряму залежність споживачів послуг від посадових осіб, які їх надають; відсутність належних умов для очікування громадян, особливо для осіб з обмеженими фрізичними можливостями, коли в коридорно-кабінетних системах органів публічної влади відсутні елементарні стільці та столи для заповнення документів, відсутні засоби для легкого доступу до цих кабінетів громадянам з особливими потребами та інше.

Акцентовано увагу, що створення центрів надання адміністративних послуг й повинно стати тією альтернативою, що значно покращить якість обслуговування громадян та допоможе запобігти корупційних ризиків. Тому Законом було передбачено створення таких центрів у першу чергу в тих органах влади, де надається максимальна кількість адміністративних послуг їх структурними підрозділами, зокрема у виконкомах міських рад міст обласного значення. Крім того, Законом передбачено заходи з децентралізації надання базових адміністративних послуг, пов'язані з необхідністю передати повноваження із прийому документів для надання адміністративних послуг та видачі їх результатів від територіальних підрозділів центральних органів виконавчої влади органам місцевого самоврядування та місцевим райдержадміністраціям.

Ключові слова: адміністративна послуга, напрямки, нормативно-правовий акт, послуга, правове регулювання, проблемні питання, шляхи вирішення.

Постановка проблеми. Законом України «Про адміністративні послуги» було зобов'язано, зокрема, міські ради міст обласного значення та районні державні адміністрації утворити центри надання адміністративних послуг (ЦНАП) до 1 січня 2014 року. Постановами Кабінету Міністрів України від 20.02.2013 року № 118 та від 01.08.2013 року № 588 були затверджені Примірне положення про центр надання адміністративних послуг та його Примірний регламент. Створення таких центрів було спрямовано на подолання багатьох проблем у сфері надання адміністративних послуг, що не тільки знижували рівень довіри громадян до органів публічної влади, але й ставали причиною проявів корупційних ризиків у цих відношеннях.

Серед таких проблем можна виділити, зокрема:

- складність процедур надання адміністративних послуг, коли замовники послуг задля їх отримання повинні збирати значну кількість документів, проміжних рішень та погоджень по різних органах влади, які частіше за все розташовані в різних місцях населених пунктів, вистоюючи підчас великі черги в адміністративних органах та очікуючи різні терміни на їх підготовку; 
- відсутність або обмежений доступ до інформації про процедури надання адміністративних послуг;

- затягування посадовими особами органів місцевого самоврядування та виконавчої влади термінів надання багатьох адміністративних послуг;

- незручний режим роботи органів влади, що надають такі послуги, який частіше за все співпадає зі звичайним графріком роботи більшості громадян та викликає певні незручності у першу чергу для фрізичних осіб, які змушені звертатись за отриманням адмінпослуг;

- відсутність альтернативних способів звернення до адміністративних органів за послугами, що ставить у пряму залежність споживачів послуг від посадових осіб, які їх надають.

- відсутність належних умов для очікування громадян, особливо для осіб з обмеженими фізичними можливостями, коли в коридорно-кабінетних системах органів публічної влади відсутні елементарні стільці та столи для заповнення документів, відсутні засоби для легкого доступу до цих кабінетів громадянам з особливими потребами та інше.

Виклад основного матеріалу. Наявність вище перелічених умов і необхідність прямого контакту замовника послуг із виконавцем часто спричиняє випадки прихованого або прямого вимагання якихось благ із боку посадових осіб від споживачів послуг або пошуку останніми іншого, «спрощеного» шляху отримання послуг за відповідну «винагороду» [1, с. 621].

Створення центрів надання адміністративних послуг й повинно стати тією альтернативою, що значно покращить якість обслуговування громадян та допоможе запобігти корупційних ризиків. Тому Законом було передбачено створення таких центрів у першу чергу в тих органах влади, де надається максимальна кількість адмінпослуг їх структурними підрозділами, зокрема у виконкомах міських рад міст обласного значення. Крім того, Законом передбачено заходи з децентралізації надання базових адміністративних послуг, пов'язані з необхідністю передати повноваження з прийому документів для надання адмінпослуг та видачі їх результатів від територіальних підрозділів центральних органів виконавчої влади органам місцевого самоврядування та місцевим райдержадміністраціям.

Станом на 01.10.2015 року у Миколаївській, Одеській та Херсонській областях центри надання адміністративних послуг було відкрито виконавчими комітетами усіх місь- ких рад міст обласного значення (16 центрів) та усіма райдержадміністраціями (59 центрів). Відкриття таких центрів відбувалось не завжди своєчасно. Із затримкою від одного до восьми місяців відкрито 13 (або 62\%) центрів у Херсонській області та 9 (або 30\%) - в Одеській області [5; 1, с. 622]. Відкриття центрів ускладнювалось певними факторами, такими як: відсутність належного приміщення, коштів на їх ремонт та створення належних умов для якісного обслуговування громадян, нестача підготовлених для цієї роботи кадрів, застаріла оргтехніка та програмне забезпечення тощо. 3 моменту відкриття по сьогоднішній день ці недоліки не вдалось повністю усунути на місцях, приміщення не підготовлено для створення відкритих та прозорих умов обслуговування споживачів послуг. Частіше за все під роботу центрів виділялось по декілька кабінетів у приміщеннях міськрад, райдержадміністрацій або інших організацій без проведення відповідного ремонту та переобладнання. Тому $є$ випадки, коли обслуговування громадян здійснюється у приміщеннях, площа яких не відповідає визначеним нормативними документами розмірам. Така ситуація спостерігається у 17 ЦНАП, що складає майже 23 відсотка від загальної кількості відкритих центрів. Причому в Саратському ЦНАП Одеської області обслуговування споживачів послуг тривалий час здійснювалось на площі 9 кв.м. (при нормі не менше 50 кв.м) на п'ятому поверсі приміщення

РДА одним адміністратором, а кількість населення Саратського району $є$ більшим, ніж у середньому в інших районах області. Не набагато краще була ситуація й у Болградському районі. У Херсонській області значні порушення у цьому напрямку спостерігались у Каланчацького ЦНАП- 10 кв.м, при нормі не менше 50 кв.м, а також у ЦНАП Голопристанської та Каховської міських рад, із площею, відповідно, - 20 кв.м. та 47 кв.м, при нормі не менше 70 кв.м. У Миколаївській області викликали занепокоєння центри Очаківської та Южноукраїнської міських рад, із площею відповідного обслуговування громадян 31 кв.м. та 47 кв.м. У таких умовах забезпечити розподіл приміщень на відкриту для відвідувачів та закриту частини, а також облаштування зон прийому (рецепції), інформування, очікування та обслуговування, забезпечити децентралізований прийом документів по базовим популярним послугам, як це передбачено нормативними документами, виявляється майже неможливим. 
3 утворених центрів шість працювали з порушенням визначеного Законом часу прийому суб'єктів звернень, коли був відсутній прийом громадян у суботу, і в деякі дні - до 20.00 години. Більшість таких порушень зафіксовано в Херсонській області (4 випадки) і жодного - в Миколаївській. Частіше така ситуація спостерігається там, де ЦНАП розміщено у приміщенні місцевої ради або адміністрації, і керівництво цих органів влади не погоджує доступ громадян до частини цих приміщень у неробочий для всього органу час [1, с. 623].

Законом визначено, що центр надання адміністративних послуг - це постійно діючий робочий орган або структурний підрозділ виконавчого органу міської, селищної ради або Київської, Севастопольської міської державної адміністрації, районної, районної у містах Києві, Севастополі державної адміністрації, в якому надаються адміністративні послуги через адміністратора шляхом його взаємодії із суб'єктами надання адміністративних послуг. Термін «робочий орган» зустрічається у різних нормативних актах, але його чіткого визначення в них не наводиться.

Роз'яснення цього терміна надано Державним комітетом України з питань регуляторної політики та підприємництва відповідно до Закону України «Про дозвільну систему у сфері господарської діяльності», згідно з яким робочий орган не є структурним підрозділом районної державної адміністрації або міського виконавчого комітету, а лише організаційним утворенням, яке забезпечує відповідну роботу місцевого дозвільного органу та державного адміністратора з питань видачі документів дозвільного характеру (переоформлення, видача дублікатів, анулювання) суб'єктам господарювання [1, с. 623]. У науково-практичному коментарі до Закону України «Про адміністративні послуги» за загальною редакцією В.П. Тимощука зазначено, що статус постійно діючого робочого органу передбачає його формування із числа працівників (посадових та/або службових осіб) різних суб'єктів надання адміністративних послуг, в тому числі залучення до складу такого органу працівників (посадових та/або службових осіб) різних суб'єктів надання адміністративних послуг принаймні для консультування [2, с. 191]. Організовуючи роботу ЦНАП, відповідні органи публічної влади обрали найбільш зручну, на їх погляд, форму утворення центрів. Так, більшість ЦНАП Миколаївської та Херсонської областей (відповідно, 75\% та 86\% від загальної кількості) працюють у фрормі постійно діючого робочого органу, а в Одеській області 83\% центрів створено структурні підрозділи райдержадміністрацій та виконкомів міськрад [1, с. 624]. Крім цього, для зручності обслуговування населення при ЦНАП можуть утворюватись територіальні підрозділи центру надання адміністративних послуг та/або віддалені місця для роботи адміністраторів такого центру. Така можливість використовується головним чином у містах, що є обласними центрами або іншими великими містами обласного значення (Київ, Вінниця, Харків, Одеса, Кривий Ріг та інші).

Для зручного обслуговування громадян Законом передбачена можливість надання у приміщеннях ЦНАП супутніх послуг (копіювання, ламінування документів, продаж канцтоварів, фотографрування, банківські послуги тощо) суб'єктами господарювання, добір яких здійснюється органом, що утворив центр надання адміністративних послуг, на конкурсній основі за критеріями забезпечення мінімізації матеріальних витрат та витрат часу суб'єкта звернення. Разом із цим було окреслено заборону надання платних супутніх послуг безпосередньо суб'єктом надання адмінпослуг або центром надання адміністративних послуг. Але практика показує, що надання таких послуг організовано лише окремими центрами, більшість яких розташовано в Одеській області. Гальмування цього процесу пов'язано як із недостатньою площею приміщень ЦНАП, так і зі складністю і суперечністю нормативних документів, що регламентують діяльність органів влади в цьому напрямку. За підсумками громадяни змушені шукати місця, де можна оплатити необхідну послугу, зробити копію відповідних документів, щоб сформувати необхідний пакет для отримання послуги тощо, і далеко не завжди суб'єкти господарювання, які надають ці послуги, знаходяться поруч із ЦНАП.

За інформацією міськвиконкомів міст обласного значення та райдержадміністрацій у Херсонській області визначено основні проблемні питання в частині створення та належного функціонування Центрів, які потребують нагального вирішення на державному рівні, а саме:

1. Відсутність затвердженого на державному рівні Переліку адміністративних послуг, які повинні надаватися через Центри.

2. Недостатній рівень підготовки адміністраторів Центрів, відсутність відповідних навчальних програм та підвищення їх кваліфрікації.

3. Невідповідність нормативно-правових актів суб'єктів надання адміністративних послуг 
вимогам чинного законодавства 3 питань надання адміністративних послуг [10, 1, с. 628].

4. Відсутність в адміністраторів центрів важелів впливу на суб'єктів надання адмінпослуг та інші.

Дійсно, відсутність затвердженого на державному рівні переліку адміністративних послуг призводить до того, що органи місцевого самоврядування та місцеві органи виконавчої влади, не дивлячись на те, що поняття таких послуг було наведено як у Концепції розвитку системи надання адміністративних послуг органами виконавчої влади, так і в Законі України «Про адміністративні послуги», не можуть або не бажають чітко визначитись, які саме види їхньої діяльності підпадають під визначення адміністративної послуги та потребують особливих умов їх здійснення для покращення обслуговування мешканців територіальних громад та запобігання корупційних ризиків у цій сфрері. Як наслідок, маємо ситуацію, коли, працюючи в однаковому правовому полі, навіть в одному регіоні, органи місцевого самоврядування декларують досить різну кількість своїх адмінпослуг. Наприклад, у міськрадах міст обласного значення, які є більш прогресивними у сфрері надання адмінпослуг, оскільки створили та забезпечують функціонування центрів надання адміністративних послуг:

- у Миколаївській області розбіжність у кількості власних послуг складала від 24 по Первомайській міській раді до 94 в Миколаївській міській раді;

- в Одеській області - від 22 по Ізмаїльській міській раді до 86 в Білгород-Дністровській міській раді;

- у Херсонській області - від 1 по Каховській міськраді до 34 в Новокаховській міській раді [1, с. 629].

Як бачимо, статус міста - обласного центру не завжди впливає на збільшення кількості таких послуг у виконкомах міськрад.

Сьогодні у процесі розгляду питань децентралізації та передачі повноважень об'єднаним громадам, зокрема із забезпечення надання адміністративних послуг через ЦНАП, які їм необхідно буде створювати, часто виникає питання, чи зможуть виконкоми знов створених територіальних громад виконати це завдання і на якому рівні? Практика показує, що майже за два роки діяльності з моменту створення центрів надання адміністративних послугорганам місцевого самоврядування все ж таки краще вдалось організувати цю роботу, ніж районним державним адміністраціям. Так, наприклад, середня кількість адмінпослуг, що надавалась через ЦНАП, утворені міськрадами міст обласного значення у Херсонській області (не враховуючи обласний центр), на 10 послуг (або в 1,2 рази) більша, ніж у центрах при райдержадміністраціях. У Миколаївській області - на 50 послуг (або в 1,8 рази більше), а в Одеській області на 94 послуги (або в 2,7 рази більше) [1, с. 629].

Згідно із Законом у населених пунктах, які $\epsilon$ адміністративними центрами областей та районів, центри надання адміністративних послуг утворюються за рішенням відповідних селищних або міських рад і можуть забезпечувати надання адміністративних послуг, у тому числі відповідними обласними, районними та міськими державними адміністраціями, на основі узгоджених рішень. У разі утворення центрів надання адміністративних послуг районними державними адміністраціями такі центри можуть забезпечувати надання адміністративних послуг обласних державних адміністрацій та органів місцевого самоврядування на основі їх узгоджених рішень. Крім цього, також на основі узгоджених рішень із суб'єктами надання адміністративних послуг через ЦНАП можуть надаватися інші адміністративні послуги і в обов'язковому порядку послуги, перелік яких затверджується Кабінетом Міністрів України. І чим більше послуг від різних органів влади надається через центр, тим краще для громадян, оскільки в такому випадку максимально забезпечується можливість обслуговування в «єдиному вікні» без необхідності відвідувати чисельні адміністративні органи. 3 метою найкращої реалізації цієї мети прогресивними у цьому напрямку міськими радами у приміщеннях ЦНАП забезпечується й надання іншого виду обслуговування, наприклад надання юридичних та профільних консультацій різними органами влади, видача архівних довідок та копій рішень міськрад, прийом звернень та скарг від громадян, прийом та обслуговування спеціалістами підприємств, що здійснюють надання комунальних послуг тощо. Звичайно, все це становиться можливим за умови достатньої площі та організації приміщень центрів, їх відповідного матеріального та кадрового забезпечення.

Проаналізувавши дані, наведені в інформаційних матеріалах з адміністративних послуг, розміщених на офіційному веб-сайті Міністерства цифрової трансформації України, можна зробити висновки про певний рівень організації обслуговування через ЦНАП та налагодження взаємодії між різними органами публічної влади 
в процесах надання адмінпослуг, зокрема через центри надання адміністративних послуг. Так, у південних регіонах України простежується дуже слабка ініціатива з боку райдержадміністрацій у цьому напрямку, оскільки через утворені ними центри надавалось у середньому від 52 (Херсонська область) до 61 (Миколаївська область) послуг. Якщо врахувати, що згідно з розпорядженням Кабінету Міністрів України від 16.05.2014 р. № 523-р через ЦНАП повинні були в обов'язковому порядку надаватись базові адміністративні послуги територіальних підрозділів центральних органів виконавчої влади у кількості 51 послуг, а також усі відповідні дозвільні документи, можна зробити висновок, що райдержадміністрації «з натяжкою» намагались виконувати зазначені вимоги, а послуги власних структурних підрозділів продовжують надавати за старими умовами без належного регулювання та прозорості. Така ситуація мала місце в Казанківському та Новоодеському районах Миколаївської області; Арцизькому, Біляївському, Великомихайлівському, Роздільнянському та Тарутинському районах Одеської області; Каховському районі Херсонської області. Крім того, загальна кількість адмінпослуг, що надається через ЦНАП у деяких райдержадміністраціях, взагалі свідчить про порушення вимог вищевказаного розпорядження Кабінету Міністрів України. Найбільший відсоток таких порушень спостерігався в Херсонській області (53\% від загальної кількості районних ЦНАП), в Одеській та Миколаївській областях такі випадки мали місце, відповідно, у $39 \%$ та $21 \%$ загальної кількості районних ЦНАП. Що стосується центрів, утворених міськими радами, то такі недоліки в південних регіонах України майже не спостерігались. Навпаки, загальна кількість послуг, що надавались через ЦНАП, сягає в деяких випадках 270 (Білгород-Дністровська міська рада), 244 (Одеська міська рада), 171 (Миколаївська міська рада) і в середньому склала 111, 150 та 62 послуг, відповідно, в Миколаївській, Одеській та Херсонській областях [1, с. 631].

У центрах надання адміністративних послуг, створених міськрадами міст - обласних центрів, на основі узгоджених рішень з обласними державними адміністраціями надаються адміністративні послуги їх структурних підрозділів. Кількість таких послуг у різних областях коливається від 5 в Херсонській ОДА до 122 в Одеській ОДА. Міськради інших міст обласного значення через ЦНАП забезпечували надання адмінпослуг районних державних адміністра- цій лише в Одеській області. В інших областях південного регіону України така взаємодія не спостерігалась. Така ж ситуація - в центрах, які утворено райдержадміністраціями - через них не забезпечується надання адмінпослуг міських та селищних рад районних центрів.

Згідно з Концепцією реформування місцевого самоврядування та територіальної організації влади в Україні, схваленою розпорядженням Кабінету Міністрів України від 01.04.2014 р. № 333-р, об'єднаним громадам будуть передані серед інших повноваження 3 надання адміністративних послуг через центри надання таких послуг [8]. Пріоритетним є об'єднання громад із центрами в містах та селищах, які $€$ на сьогоднішній день районними центрами. Тому саме органи місцевого самоврядування у таких містах та селищах повинні будуть перебрати на себе обов'язок зі створення ЦНАП та організації їх якісної роботи. Це, з одного боку, полегшить завдання таких ОТГ, оскільки в багатьох випадках працювати доведеться не «з нуля», а використовуючи передані від РДА вже створені центри з можливістю роботи в них вже підготовлених кадрів. А з іншого боку, відсутність на теперішній час взаємодії між міськими та селищними радами з районними державними адміністраціями буде гальмувати в подальшому децентралізацію у сорері надання адміністративних послуг у таких центрах об'єднаних громад.

Крім власних веб-сайтів, міські ради міст обласного значення передають інформацію про роботу центрів надання адміністративних послуг та про кількість послуг, що через них надаються, для оприлюднення на офіційному веб-сайті Міністерства цифрової трансформації України, яка щоквартально оновлюється. Також щокварталу органи місцевого самоврядування та виконавчої влади надають оновлену інформацію про адмінпослуги, що ними надаються, для внесення до державного Реєстру адміністративних послуг. Разом із тим ідентична інформація одних і тих самих органів публічної влади, що міститься на різних ресурсах, дуже відрізняється (таблиця 1), що свідчить:

- про неналежну якість звітної інформації;

- про неповний обсяг надання власних адмінпослуг через свої ЦНАП. Тобто через центри надання адміністративних послуг міські ради надавали лише від 55\% (Одеська, Херсонська області) до 83\% (Миколаївська область).

Слід також зазначити, що хоча майже усі міські ради, що утворили ЦНАП, затвердили в переліках адміністративних послуг, що нада- 
Кількість адміністративних послуг, що надаються виконкомами міст обласного значення

\begin{tabular}{|c|c|c|c|c|}
\hline \multirow{3}{*}{$\begin{array}{l}\text { № } \\
\text { 3/ח }\end{array}$} & \multirow[b]{3}{*}{ Орган влади } & \multicolumn{3}{|c|}{ Кількість власних адмінпослуг } \\
\hline & & \multicolumn{2}{|c|}{ Надаються через ЦНАП } & \multirow{2}{*}{$\begin{array}{c}\text { За даними } \\
\text { Держреєстру } \\
\text { адміністратив- } \\
\text { них послуг }\end{array}$} \\
\hline & & $\begin{array}{c}\text { За даними, } \\
\text { надісланими } \\
\text { Мінрегіонбуду }\end{array}$ & $\begin{array}{c}\text { Згідно даних, } \\
\text { розміщених на сайті } \\
\text { ЦНАП }\end{array}$ & \\
\hline \multicolumn{5}{|c|}{ Миколаївська область } \\
\hline 1 & Облдержадміністрація & 17 & - & 53 \\
\hline 2 & Миколаївська міськрада & 94 & 52 & 71 \\
\hline 3 & Вознесенська міськрада & 54 & 15 & 51 \\
\hline 4 & Очаківська міськрада & 30 & 33 & 58 \\
\hline 5 & Первомайська міськрада & 24 & 50 & 41 \\
\hline 6 & Южноукраїнська міськрада & 40 & & 72 \\
\hline \multicolumn{5}{|c|}{ Одеська область } \\
\hline 1 & Облдержадміністрація & 122 & 92 & 20 \\
\hline 2 & Одеська міськрада & 42 & 61 & 118 \\
\hline 3 & Білгород-Дністровська міськрада & 86 & 86 & 160 \\
\hline 4 & Ізмаїльська міськрада & 22 & 22 & 33 \\
\hline 5 & Черноморська (Іллічівська) міськрада & 74 & 98 & 96 \\
\hline 6 & Подільська (Котовська) міськрада & 27 & 28 & 63 \\
\hline 7 & Теплодарська міськрада & 24 & 27 & 49 \\
\hline 8 & Южненська міськрада & 66 & - & 111 \\
\hline \multicolumn{5}{|c|}{ Херсонська область } \\
\hline 1 & Облдержадміністрація & 5 & - & 29 \\
\hline 2 & Херсонська міськрада & 22 & 22 & 22 \\
\hline 3 & Голопристанська міськрада & 17 & 17 & 35 \\
\hline 4 & Каховська міськрада & 34 & 34 & 32 \\
\hline 5 & Новокаховська міськрада & 1 & 4 & 41 \\
\hline
\end{tabular}

Джерело: складено автором на основі джерел [3; 4; 5; 9; 6; 10]

ються через центри, послуги Державної реєстраційної служби з реєстрації підприємницької діяльності та нерухомого майна, фрактично такі послуги до травня 2016 року надавались безпосередньо державними реєстраторами в цій службі, оскільки не було внесено змін до відповідних законодавчих актів про заборону здійснювати прийом документів на надання послуг у цій сфері та видачу їх результатів безпосередньо суб'єктами надання таких послуг і не було надано ЦНАП можливості доступу до відповідних реєстрів. Таким чином, фактично децентралізації повноважень із прийому та видачі документів по базовим адміністративним послугам Міністерства юстиції України не відбувалось аж до прийняття закону про повну передачу обов'язків із реєстрації підприємництва та нерухомості органам місцевого самоврядування.

Аналіз оприлюднених переліків послуг у розрізі за видами діяльності місцевих органів влади показав відсутність опрацьованих ними узагальнених висновків щодо необхідності визначення певних видів діяльності цих органів як адміністративної послуги.
Особливості місцевого самоврядування припускає розмаїття утворених у складі виконкомів різних структурних підрозділів та деякі незначні відмінності в потребах громадян різних територіальних громад щодо отримання адмінпослуг. Проте не може бути значних відмінностей у наданні цих послуг, наприклад: із питань праці та соціального забезпечення (кількість таких послуг у переліках коливається від нуля до шістдесяти), у захисті справ дітей (від 0 до 13 послуг) тощо [1, с. 635].

Висновки. Отже, багато послуг міськвиконкомів, що потрапили до Реєстру адміністративних послуг, оприлюдненого на офріційному веб-сайті Міністерства цифрової трансформації України, визначені невірно. Служба у справах дітей Очаківської міської ради помилково віднесла до адмінпослуг такі функції, як «Реєстрація народження підкинутої чи знайденої дитини» та «Надання дитині статусу дитини-сироти або дитини, позбавленої батьківського піклування». Здійснення цих процедур не передбачає звернення споживача таких послуг за її наданням, це $є$ необхідні дії служби з метою захисту прав дітей. Управління соці- 
ального захисту населення Очаківської міської ради вказує серед своїх послуг «Визначення статусу громадян, які постраждали внаслідок Чорнобильської катастрофи, та видача дубліката посвідчення у разі його втрати або псування», що фактично є послугою облдержадміністрації. Голопристанська міська рада чомусь віднесла до адміністративних послуг «Надання довідки-характеристики на громадян за місцем проживання виконавчого комітету», що не передбачено владними повноваженнями міськради, визначеними законом. Одним із структурних підрозділів Одеської міської ради серед адміністративних послуг зазначено «Підготовку проекту рішення виконавчого комітету», хоча це не має абсолютно ніякої конкретики та може бути лише проміжним етапом у підготовці рішення з надання якоїсь адмінпослуги. Крім того, Одеська міська рада віднесла до адміністративних багато послуг, що надаються її комунальними підприємствами, наприклад: «Погодження на розміщення рекламних конструкцій на зеленій зоні міста» (КП «Міськзелентрест»); «Узгодження проектування, будівництва, реконструкції, розширення, технічного переобладнання» (КП «Міжнародний аеропорт Одеса»); «Видача технічних умов на реконструкцію та капітальний ремонт вулиць м. Одеси» (КП «Міські дороги») та інші.

\section{Список використаної літератури:}

1. Місцеве самоврядування в умовах децентралізації влади в Україні: колективна монографія. / за заг. ред. Р.М. Плюща. Київ : РІДНА МОВА, 2016. 744 c.

2. Науково-практичний коментар до Закону України «Про адміністративні послуги» / за заг. ред. В.П. Тимощука. Київ : ФОП Москаленко О.М. 392 с.

3. Офріційний веб-портал міста Черноморськ (Іллічівськ). URL : http://www.ilyichevsk-rada.gov.ua/.

4. Офріційний веб-сайт виконавчого комітету Теплодарської міської ради. URL : http://www.teplodar.biz.ua/.

5. Офріційний веб-сайт Міністерства цифрової трансформації України. URL: https://thedigital. gov.ua/committees.

6. Офріційний веб-сайт міста Ізмаїл. URL : http://www.izmail-rada.gov.ua/.

7. Офріційний веб-сайт Херсонської обласної державної адміністрації. URL : http://khoda.gov.ua/.

8. Про схвалення Концепції реформування місцевого самоврядування та територіальної організації влади в Україні: Розпорядження Кабінету Міністрів України від 01.04.2014 р. № 333-p. URL : http://zakon5.rada.gov.ua/laws/ show/333-2014-\%D1\%80.

9. Офріційний веб-сайт міста Білгород-Дністровський. URL : http://www.bilgorod-d.org.ua/.

10.Офріційний веб-сайт Херсонської обласної державної адміністрації. URL : http://khoda.gov.ua/.

Fedorishchev S. S. Activities of centers for provision of administrative services: problem issues and ways of the solution

The article covers the activities of administrative service centers: problematic issues and ways to solve them. Among the problems in the activities of administrative service centers can be identified in particular: the complexity of procedures for providing administrative services, when customers to obtain them must collect a significant number of documents, interim decisions and approvals of various authorities, most often located in different localities, enduring long queues in administrative bodies, and waiting for different deadlines for their preparation; lack or limited access to information on the procedures for providing administrative services; delays in the terms of providing many administrative services by officials of local self-government bodies and the executive power; inconvenient mode of work of the authorities providing such services, which most often coincides with the usual work schedule of the majority of citizens and causes certain inconveniences, first of all, for individuals who are forced to apply for administrative services; lack of alternative ways to apply to administrative bodies for services, which makes consumers directly dependent on officials who provide them; lack of appropriate conditions for waiting for citizens, especially for people with disabilities, when in the corridor-cabinet systems of public authorities there are no basic chairs and tables for filling out documents, no means for easy access to these offices for citizens with special needs and more.

Emphasis is placed on the fact that the establishment of administrative service centers should be the alternative that will significantly improve the quality of service to citizens and help prevent corruption risks. Therefore, the Law provided for the establishment of such centers primarily in those authorities where the maximum number of administrative services is provided by their structural units, in particular in the executive committees of city councils of cities of regional importance. In addition, the Law provides for measures to decentralize the provision of basic administrative services related to the need to delegate the authority to receive documents for the provision of administrative services and issue their results from territorial units of central executive bodies to local governments and local district administrations.

Key words: administrative service, directions, normative-legal act, service, legal regulation, problem questions, ways of the decision. 


\title{
КРИМІНАЛЬНЕ ПРАВО ТА КРИМІНОЛОГІЯ; КРИМІНАЛЬНО-ВИКОНАВЧЕ ПРАВО
}

\author{
УДК 343:9 \\ DOI https://doi.org/10.32840/1813-338X-2020.3.19
}

T. М. Беркій

аспірант кафедри кримінально-правових дисциплін юридичного факультету

Львівського державного університету внутрішніх справ

\section{ШЛЯХИ ВДОСКОНАЛЕННЯ ЗАСОБІВ ПОПЕРЕДЖЕННЯ ТА ПРОТИДІЇ СЕПАРАТИЗМУ В УКРАЇНІ}

У статті проаналізовано основні засоби попередження та протидії сепаратизму в Україні, а також основні шляхи їх удосконалення. Проаналізовано співвідношення понять попередження та протидії. Зазначено основні критерії, за якими класифрікують заходи запобігання злочинності загалом. Зокрема, виокремлено основні засоби попередження сепаратизму: правові, інфоормаційні, соціальні, фрінансові, міжнародні. У статті наголошується на тому, що, зокрема, правові засоби поодиниі не є ефективними. Вказується, що правові механізми демонструють свою дієвість та ефективність на превентивній стадії - запобігання сепаратизму. Зараз більш вагому роль відіграють політичні, міжнародні механізми врегулювання сепаратистських конфліктів. Також проаналізовано соціальні засоби протидії сепаратизму. Зазначається, що потрібно покращувати соціальне благополуччя населення на всій території держави, а також на тимчасово окупованих територіях. Встановлено, що неабияке значення сьогодні мають саме інфрормаційні засоби попередження та протидії сепаратизму в Україні. Зокрема, необхідно внести зміни до Кримінального кодексу України, а точніше розділ I доповнити статтею в такому вигляді: "Стаття 109-1. Поширення інфоормації чи відомостей, що становлять загрозу національним інтересам України Пропаганда іноземної держави, яка спрямована на насильницьку зміну чи повалення конституційного ладу або захоплення державної влади, а також поширення інфрормації чи відомостей, що становлять загрозу національним інтересам України, карається...». Що стосується фрінансових засобів протидії сепаратизму, то влада, фрахівці, експертна спільнота мають зробити рішучі кроки щодо вдосконалення фрінансової безпеки. Загалом у статmі підсумовано, що всі засоби протидії сепаратизму мають фрунціонувати у взаємодії. Має бути відпрацьований цілий механізм протидії сепаратизму. Саме в Україні, яка напряму зіткнулась із проблемою сепаратизму, має першочергова увага приділятися вдосконаленню засобів протидії та попередження сепаратизму. Неабияке значення має вдосконалення власне національних засобів попередження та протидії сепаратизму.

Ключові слова: сепаратизм, протидія, інфрормаційні засоби, правові засоби, міжнародні переговори.

Постановка проблеми. Протидія злочинності - це складне соціально-правове явище та поняття про нього, в якому відображається теорія і практика специфічної соціально-управлінської діяльності та суспільних і приватних ініціатив, а також кримінально юстиційних зусиль, спрямованих на перешкоджання вчиненню кримінальних правопорушень і реагування на їх вчинення [1, с. 105]. Вважається, що основними складниками протидії злочинності є запобігання та її попередження.

Аналіз останніх досліджень і публікацій. Думку про те, що запобігання злочинності мусить мати пріоритет перед каральною політикою держави, висловив ще Платон у IV столітті до нашої ери. Правову аргументацію ця думка 
одержала у XVIII столітті в роботах юристів класичної школи кримінального права, що заклали основу нової політики в боротьбі зі злочинністю. I нині лишається актуальним вислів про те, що історія й така наука, як статистика, з вичерпною очевидністю доводять, що з часів Каїна світу ніколи не вдавалося ні виправити, ні залякати покараннями [2, с. 191].

Про актуальність розроблення питань запобігання злочинності свідчить те, що названі питання завжди привертали увагу науковців. Це праці таких видатних дослідників, як Ю.М. Антоняна, О.М. Бандурки, В.В. Голіни, Л.М. Давиденка, В.Д. Малкова, В.М. Кудрявцева, В.Е. Емінова та інших[3, с. 590].

Мета статті. Враховуючи те, що проблема сепаратизму для України $\epsilon$ актуальною, потрібно не лише розуміти сутність і причини виникнення цього явища. Також увагу слід звернути на основні засоби протидії цьому феномену та виробити дієвий механізм протидії сепаратистським появам в майбутньому.

Виклад основного матеріалу. В українській науці, зокрема кримінології, під поняттям запобігання злочинності розуміють сукупність різноманітних видів діяльності та заходів у державі, спрямованих на вдосконалення суспільних відносин із метою усунення негативних явищ і процесів, що породжують злочинність або сприяють їй, а також недопущення вчинення злочинів на різних стадіях злочинної поведінки.

За рівнем розрізняються загальносоціальні, спеціально-кримінологічні та індивідуальні заходи запобігання злочинності; за масштабом - заходи, які здійснюються в територіальному розрізі, на окремому об'єкті, щодо групи осіб; за змістом - заходи соціально-економічного, соціально-демографічного, технічного, екологічного, правового та іншого характеру; за суб'єктами - заходи, що здійснюються органами всіх гілок влади, організаціями, трудовими об'єднаннями, установами, окремими громадянами; за об'єктами - відповідно до видів злочинів, на протидію яким вони спрямовані [4, с. 52].

Тобто під запобіганням треба розуміти діяльність, що перешкоджає вчиненню кримінальних правопорушень, не допускає їх вчинення. Запобігати означає «не допускати чогось заздалегідь, відвертати».

Коли профрілактика виявляється не досить ефрективною, виникає потреба в застосуванні другого засобу запобігання - попередження кримінального правопорушення. Попередження - це сукупність заходів, безпосередньо спрямованих на свідомість конкретних осіб або окремих їхніх груп, які мають злочинні наміри, замислюють вчинення злочину. На рівні індивідуального запобігання злочинам попередження проявляється як інформування потенційного злочинця про нераціональність спланованого ним кримінального правопорушення. Головною ознакою цієї форми запобігання $€$ наявність зусиль, що застосовуються до конкретних осіб, які вже мають намір вчинити злочин. 3 позиції кримінального права це означає, що попередженням злочину є діяльність суб'єктів запобігання на стадії виявлення умислу на його вчинення[1, с. 107-108].

Попередження та запобігання сепаратизму відіграє неабияку роль під час забезпечення внутрішньої безпеки держави, зокрема України.

В етнопології спостерігається велика кількість класифікацій методів, засобів, стратегій протидії та нейтралізації сепаратизму. Майже кожен прояв сепаратизму $є$ різновидом етнополітичного конфолікту, якщо в ньому присутній етнокультурний чинник. А. Кіссе стверджує, що врегулювання таких конфлліктів здійснюється шляхом застосування політико-правових механізмів; переговорів і посередництва (миротворчі місії); інфоомаційних методів (наприклад, повідомлень у 3МІ, що відображають позицію обох сторін). За словами дослідника, ці мирні засоби можуть бути застосовані лише в мирний час, на етапі безпосередньої конфліктної взаємодії - війн, збройних протистоянь, дієвими $\epsilon$ заходи судово-каральні, соціально-політичного або військового стримування [5, с. 307].

Варто розглянути найбільш дієві та актуальні для України засоби протидії сепаратизму.

Правові засоби. І.О. Кресіна зазначає, що правові засоби боротьби з цим феноменом не $€$ найчастіше заснованими державами в активній фразі протидії сепаратизму. Незначний рівень застосування правових механізмів боротьби з проявами сепаратизму в його активній фразі пояснюється їхньою неефективністю, зумовленою неможливістю застосування на територіях, охоплених сепаратизмом. Український досвід 2014 року підтверджує слушність цього припущення. Наприклад, у Криму правоохоронні структури повністю підкорялися самопроголошеній владі, тому не виконували закони України та нормативно-правові акти центральної влади, спрямовані на блокування сепаратизму. Правові механізми демонструють свою дієвість та ефрективність 1) на превентивній стадії запобігання сепаратизму, а також 2) в умовах 
збереження за центральною владою та правоохоронними органами контролю територій, охоплених сепаратизмом. Навздогінне запровадження нових правових механізмів боротьби з сепаратизмом не демонструє такої ефективності. Це також підтверджує досвід боротьби з сепаратизмом в Україні 2014 року. Зокрема, Генпрокуратура України визнала самопроголошені Донецьку Народну Республіку (ДНР) і Луганську Народну Республіку (ЛНР) терористичними організаціями. Однак, щоб припинити діяльність цих незаконних утворень в Україні, судового рішення не досить, доводиться фрактично вести проти них війну - таку назву серед експертів отримала Антитерористична операція з огляду на кількість залученої техніки, зброї, військових і кількість загиблих.

Неврахування новітніх загроз, зокрема етнополітичної дестабілізації в окремих регіонах України, можливих проявів сепаратизму на етапі запобігання цих явищам за допомогою правових, політичних, етнополітичних механізмів, призвело до таких трагічних для України наслідків - втрати Криму, контролю над східними областями, війни, людських жертв і матеріальних збитків. На нинішньому етапі на перший план виходять політичні, зокрема міжнародні, та силові засоби протидії сепаратизму. Застосування правових механізмів, норм українського законодавства в регіонах, охоплених сепаратизмом, обмежене через відсутність або неможливість становлення контролю на окупованій території Криму та Сході України [6, с. 352-359].

Інформаційні засоби. Стаття 34 Конституції України наголошує, що кожному гарантується право на свободу думки і слова, на вільне вираження своїх поглядів і переконань. Кожен має право вільно збирати, зберігати, використовувати й поширювати інформацію усно, письмово або в інший спосіб - на свій вибір. Здійснення цих прав може бути обмежено законом в інтересах національної безпеки, територіальної цілісності або громадського порядку з метою запобігання заворушенням чи злочинам, для охорони здоров'я населення, для захисту репутації або прав інших людей, для запобігання розголошенню інформації, одержаної конфіденційно, або для підтримання авторитету й неупередженості правосуддя [7, с. 99].

При цьому необхідно зауважити, що РФ здійснює цілеспрямований негативний інформаційно-психологічний вплив (через проведення окремих чи об'єднаних між собою акцій, операцій, кампаній) на Україну незалежно від того, які сили перебували при владі, а виключно з огляду на власні короткострокові чи стратегічні інтереси. Основним же пріоритетом для російського керівництва $€$ перерозподіл і посилення свого політичного й економічного впливу у світі, насамперед у спосіб забезпечення відновлення домінантних позицій на пострадянському просторі із залученням України до сфери свого геополітичного впливу. У зв'язку з цим варто зауважити, що сьогодні в Україні досі не ухвалено керівних документів державної політики, що відображали би стратегії розвитку держави як у сфері розвитку національного інформаційного простору, так і у сфрері розвитку офіційної комунікації. Тому зараз необхідно розробити відповідні керівні документи: Стратегію розвитку національного інформаційного простору (щодо діяльності традиційних 3MІ і новітніх ЗМК, інтернету, інформаційних агентств, книговидання, кіноіндустрії тощо) та Стратегію розвитку офріційної комунікації (щодо розвитку відповідного інституційного складника, процесів інформування громадськості, формування іміджу, брендингу тощо) [8].

Деякі автори також пропонують доповнити Розділ I Особливої частини Кримінального кодексуУкраїни «Злочинипротиосновнаціональної безпеки» статтею такого змісту, виклавши iï, наприклад, у такому вигляді: «Стаття 109-1. Поширення інформації чи відомостей, що становлять загрозу національним інтересам України. Пропаганда іноземної держави, яка спрямована на насильницьку зміну чи повалення конституційного ладу або захоплення державної влади, а також поширення інформації чи відомостей, що становлять загрозу національним інтересам України, карається...» [7, с. 102].

Фінансові засоби. Нестабільність економічного стану в Україні останнім часом мають украй загрозливий характер для її національної безпеки. Це перш за все пов'язано з політичною нестабільністю, що породжена як внутрішніми, так і зовнішніми факторами впливу; катастрофічним розвитком кримінальної економіки та розкраданням державного майна; переведенням коштів у «тінь» і з подальшим використанням для розвитку кримінально-тіньової економіки.

За умов динамічного розвитку світогосподарських процесів, глобалізації світових економічних систем відбуваються зміни у структурі тіньових процесів, які спонсорують різноманітні сепаратистські рухи та збройні конфлікти. У зв'язку з цим виникає нагальна потреба розроблення науково обґрунтованих стратегій 
боротьби з відмивання грошей і припинення фрінансування тероризму. Провідне місце в запобіганні розвиткові цих явищ посідають підрозділи фрінансової розвідки (ПФР) [9, с. 60-67].

Саме тому влада, фахівці, експертна спільнота мають зробити рішучі кроки щодо вдосконалення фінансової безпеки.

Зокрема, необхідно спільними зусиллями:

- розробити та запровадити дієві механізми попередження загроз;

- модернізувати законодавство;

- впровадити сучасні форми взаємодії різних владних структур та інституцій у питаннях фрінансової безпеки та фрінансового моніторингу;

- запобігти впливу російського капіталу в будь-яких формах на внутрішньодержавні процеси в Україні.

Держава має гарантувати такий стан захищеності фрінансових інтересів, який дасть змогу реформувати всі проблемні сфери суспільного життя, а відтак - подолати конфрлікт на сході країни. Тільки за таких умов Україна матиме європейське майбутнє та стане цивілізованою правовою державою [10].

Міжнародні засоби. Міжнародні інструменти $€$ критично важливими для надання допомоги у розв'язанні проблеми сепаратизму, особливо, коли вони застосовуються досить рано, щоб не допустити ескалації конфрлікту. Різна заходи, такі як дипломатія, моніторинг прав меншин, і врегулювання спорів можуть бути використані для забезпечення того, щоб держави і меншини взаємодіяли продуктивно та мирно. Переговори та посередництво також можуть бути інколи ефективними. У цьому зв'язку міжнародне втручання вважається більш ефективним засобом розв'язання сепаратистських конфрліктів. Відповідно до статті 41 Статуту $\mathrm{OOH}$, Рада Безпеки має виключне право накладати обов'язкові санкції на державу. ОБСє також розробила посередницький механізм, орієнтований на запобігання конфліктам і пошук політичного рішення в постраждалих країнах. Варто зазначити, що ОБСє є активним учасником діалогу врегулювання конфрліктів у пострадянських державах. Також ефективним $є$ залучення провідних держав світу (США. Англія, Німеччина, Франція) до процесу боротьби з сепаратизмом. Переговорний процес і дипломатичні канали це історично підтверджений вагомий механізм розв'язання конфоліктів [11, с. 8-13].

Соціальні засоби. За даними Міністерства соціальної політики України станом на жовтень 2019 року в Україні обліковано
1 млн 413,6 тис. внутрішньо переміщених осіб із Донбасу і Криму. Зокрема - понад 785 тис. пенсіонерів, 240 тис. дітей і приблизно 48 тис. осіб з інвалідністю. За висновками міжнародних експертів, Україна не вживає достатніх заходів для дотримання прав своїх громадян, які постраждали внаслідок анексії Криму та війни на сході, як це передбачено ії зобов'язаннями відповідно до Міжнародного пакту про економічні, соціальні та культурні права, який був ратифрікований Україною 19 жовтня 1973 року. Внутрішньо переміщені особи та особи, які залишилися проживати на тимчасово окупованій території, стикаються з численними проявами дискримінації. Здебільшого це прямий наслідок законодавчо встановлених обмежень у доступі до реалізації певних прав і свобод осіб, що проживали чи залишилися проживати на тимчасово окупованій території. Для недопущення проявів сепаратизму потрібно підвищувати соціальний рівень життя громадян, особливо на територіях, які необхідно повернути до складу України [12].

Висновки і пропозиції. Враховуючи вищевикладене, варто узагальнити, що у процесі запобігання та попередження сепаратизму не можна використовувати один із вищеописаних засобів окремо. Всі ці засоби протидії сепаратизму мають фуннкціонувати та працювати одночасно й ефективно. Крім того, доцільним буде вивчення та врахування досвіду іноземних держав у боротьбі з цим явищем. I на основі цього потрібно вдосконалювати національні засоби попередження та протидії сепаратизму.

\section{Список використаної літератури:}

1. Протидія злочинності: сутність і зміст : науковий часопис Національної академії прокуратури України. 2016. No 4. С. 103-112. URL: http://www.chasopysnapu.gp.gov.ua/ua/pdf/ 12-2016/kuts.pdf.

2. Корягіна А. Запобігання злочинності як різновид соціально-профілактичної діяльності. Підприємництво, господарство і право. 2016. № 11. C. 191-196. URL: http://nbuv.gov.ua/UJRN/ Pgip_2016_11_39.

3. Літвінов Є.В. Запобігання злочинності судовими органами України: поняття, функції та завдання. Форум права. 2012. № 4. С. 590-594. URL: http://nbuv.gov.ua/UJRN/FP_index.htm_ 2012_4_96.

4. Кримінологія: Загальна та Особлива частини : підручник для студентів юрид. спец. вищ. навч. закладів/І.М.Даньшин, В.В. Голіна, М.Ю. Валуйська та ін. ; за заг. ред. В.В. Голіни. 2-ге вид. перероб. і доп. Харків : Право, 2009. 288 с. 
5. Особливості боротьби з сепаратизмом в Україні: роль громадянського суспільства / В.П. Горбатенко, С.В. Стоєцький, Л.О. Матвійчук // Держава і право. Юридичні і політичні науки. 2014. Вип. 65. С. 306-313. URL: http://nbuv.gov.ua/ UJRN/dip 20146545.

6. Кресіна І.О. Правові механізми запобігання та протидії сепаратизму в Україні. Держава і право. Юридичні і політичні науки. 2014. Вип. 64. С. 352-359. URL: http://nbuv.gov.ua/ UJRN/dip_2014_64_52.

7. Притула А.М. Пропаганда - компонент гібридної війни: шляхи протидії засобами кримінального права. Юридична наука. 2015. № 3. C. 99-104. URL: http://nbuv.gov.ua/UJRN/ jnn_2015_3_14.

8. Конах В.К. Негативні інформаційно-психологічні впливи Російської Федерації проти Укра- їни та можливі засоби протидії. Стратегічні пріоритети. 2014. № 3. С. 23-30.

9. Куриліна О.В. Створення підрозділів фінансової розвідки як потреба в умовах боротьби 3 економічним сепаратизмом. C. 60-67. URL: file:///C:/Users/gerc0/AppData/Local/Temp/ Vzuk_2014_37_11-1.pdf.

10.Фінансова безпека України: ключові виклики та завдання. URL: http://www.visnuk.com.ua/ uk/news/100006350-finansova-bezpeka-ukrayiniklyuchovi-vikliki-ta-zavdannya.

11. Здоровега М., Цебенко О. Міжнародно-політичні механізми протидії сепаратизму на пострадянському просторі. 2015. Vol. 2. Iss. 4. C. 8-13. URL: http://nbuv.gov.ua/UJRN/evrpol_2015_2_4_3.

12. Соціальний вплив держави на протидію сепаратизму в Україні. URL: http://app.onua.edu.ua/ index.php/app/article/view/204/201.

Berkii T. M. Ways to improve the means of preventing and combating separatism in Ukraine

This article analyzes the main means of preventing and combating separatism in Ukraine, as well as the main ways to improve them. In particular, the main means of preventing separatism are identified: legal, informational, social, financial, international. The main criteria according to which crime prevention measures in general are classified are indicated. It is pointed out that legal mechanisms demonstrate their effectiveness and efficiency at the preventive stage prevention of separatism. The article emphasizes that, in particular, legal remedies alone are not effective. Political and international mechanisms for resolving separatist conflicts now play a more important role. Also, social means of counteracting separatism are analyzed. It is noted that it is necessary to improve the social welfare of the population throughout the country, as well as in the temporarily occupied territories. It has been established that information means of preventing and counteracting separatism in Ukraine are of great importance today. In particular, it is necessary to amend the Criminal Code of Ukraine, or rather section I, to supplement the article, as follows: "Article 109-1. Dissemination of information or information that threatens the national interests of Ukraine Propaganda of a foreign state aimed at forcible change or overthrow of the constitutional order or seizure of state power, as well as dissemination of information or information that threatens the national interests of Ukraine, is punishable ...". As for the financial means to combat separatism, the authorities, experts and the expert community must take decisive steps to improve financial security. In general, the article concludes that all means of combating separatism should function in interaction. The whole mechanism of counteraction to separatism must be worked out. It is in Ukraine, which is directly confronted with the problem of separatism that priority is given to improving the means of counteracting and preventing separatism. It is of great importance to improve the actual national means of preventing and combating separatism.

Key words: separatism, counteraction, information means, legalmeans, international negotiations. 
Д. А. Коваленко

здобувач кафедри кримінального права Національної академії внутрішніх справ

\section{ПРОБЛЕМНІ ПИТАННЯ ОБ'ЄКТИВНОЇ СТОРОНИ КРИМІНАЛЬНОГО ПРАВОПОРУШЕННЯ ЗА ПЕРЕШКОДЖАННЯ 3'ЯВЛЕННЮ СВІДКА, ПОТЕРПІЛОГО, ЕКСПЕРТА, ПРИМУШУВАННЯ ЇХ ДО ВІДМОВИ ВІД ДАВАННЯ ПОКАЗАНЬ ЧИ ВИСНОВКУ}

Одним з основних завдань рефрормування судової системи України є створення незалежної та дієвої судової влади, яка є гарантом забезпечення прав і свобод людини в Україні. Водночас вчинення кримінальних правопорушень, які посягають на правосуддя, здатне заподіяти шкоду тому порядку суспільних відносин, який охороняється нормами розділу XVIII Особливої частини Кримінального кодексу України, що забезпечує здійснення справедливого правосуддя, яке гарантує ефективне поновлення у правах. Склад кримінального правопорушення - це єдина, необхідна і достатня підстава кримінальної відповідальності. Передбачена відповідальність за кримінальне правопорушення, передбачене cm. 386 КК України, складається з двох фрорм: 1) перешкоджання з'явленню свідка, потерпілого або експерта до суду, органів досудового слідства, тимчасових слідчих і тимчасових спеціальних комісій ВРУ чи дізнання; 2) примушування їх до відмови від давання показань чи висновку, а також давання завідомо неправдивих показань чи висновку шляхом погрози вбивством, насильством, знищенням майна цих осіб чи їхніх близьких родичів або розголошення відомостей, що їх ганьблять, або підкуп свідка, потерпілого чи експерта з тією самою метою, а також погроза вчинити зазначені дії з помсти за раніше дані показання чи висновок. Визнається кримінальне правопорушення закінченим із моменту вчинення однієї із зазначених у законі дій (перешкоджання чи примушування) незалежно від того, чи вдалося насправді перешкодити з'явленню свідка, потерпілого, експерта до слідчо-судових органів, примусити або схилити їх до відмови від давання чи до давання завідомо неправдивих показань або висновку. Але поза межами перебувають дії, які є фрактичною реалізацією тієї погрози, що висловлювалася винним, і які (за умови їх реального вчинення) підлягають самостійній кваліфрікації. Об'єктивна сторона кримінального правопорушення, передбаченого cm. 386 КК України, характеризується активними діями, а час вчинення обмежується лише часом роботи досудового слідства, судового провадження, а також часом розслідування тимчасових слідчих і спеціальної тимчасової слідчої комісії Верховної Ради України, а інші будь-які рамки або обмеження в часі (певний проміжок часу, часовий період) не мають жодного значення для об'єктивної сторони кримінального правопорушення, передбаченого сm. 386 КК України.

Ключові слова: перешкоджання, з'явлення, примушування, свідок, потерпілий, експерт, відмова, показання.

Постановка проблеми. Нині підвищення ефективності правосуддя - це одне з пріоритетних завдань нашої держави, від впровадження яких у судову систему, а також у діяльність органів, що сприяють здійсненню правосуддю, залежатиме дотримання прав і свобод людини в Україні, їхніх законних інтересів. Охорона порядку здійснення правосуддя $€$ одним з основних і першочергових завдань кримінального законодавства України. Адже саме пра- восуддя забезпечує дотримання чинного законодавства в державі, відповідно, підтримуючи належний правопорядок у суспільстві. Саме тому одним із основних завдань кримінального законодавства України $є$ охорона правосуддя від протиправних посягань як із боку службових осіб, так і осіб, які до них не належать, але $€$ учасниками процесу. Важливим складником здійснення правосуддя в Україні $€$ всебічне, повне та об'єктивне дослідження всіх обставин 
кримінального впровадження, що відбувається за внутрішнім переконанням особи, яка виступає від імені держави та вживає до особи, винної у вчиненні кримінального правопорушення, заходів державного примусу.

Аналіз останніх досліджень і публікацій. Проблеми об'єктивної сторони кримінального правопорушення, передбаченого ст. 386 КК України, на рівні підручників, навчальних посібників, а також у вигляді підрозділів монографій досліджували В.І. Тютюгін, В.І. Борисов, М.І. Хавронюк, М.І. Мельник, О.І. Габро, Н.Ю. Алексеєва, М.І. Панов та інші. Проте досі ці питання не отримали свого належного розв'язання.

Мета статті - розкриття проблемних питань, що стосуються об'єктивної сторони кримінального правопорушення, передбаченого ст. 386 КК України за кваліфікації цього діяння.

Виклад основного матеріалу. Кримінальний кодекс України не дає поняття складу кримінального правопорушення, але згідно з ч. 1 ст. 2 КК України підставою кримінальної відповідальності $€$ вчинення особою суспільно небезпечного діяння, яке містить склад кримінального правопорушення, передбаченого Кримінальним кодексом [3, с. 5]. Поняття складу кримінального правопорушення, а саме те, що таке злочин і кримінальний проступок, дає наука кримінального права. Зокрема, П.Л. Фріс зазначає, що склад кримінального правопорушення є сукупністю об'єктивних і суб'єктивних ознак, об'єднаних у чотири групи, кожна з яких має свій юридичний зміст. Це система, що має свою внутрішню структуру (елементи, їх співвідношення та взаємозв'язок), і як системне утворення вона має досліджуватись методами системного аналізу [4, с. 120]. В.К. Матвійчук щодо складу кримінального правопорушення розуміє сукупність встановлених у законі про кримінальну відповідальність об'єктивних і суб'єктивних ознак, які визначають вчинене суспільно небезпечне діяння як кримінальне правопорушення. Далі науковець вказує, що у нормах Загальної частини КК України містяться лише ті об'єктивні та суб'єктивні ознаки складу, що властиві всім кримінальним правопорушенням або багатьом із них. Саме ці ознаки в об'єднанні з ознаками, описаними вже в конкретних нормах Особливої частини КК України, і утворюють склад конкретного вчиненого кримінального правопорушення. Стисло формулюючи ознаки конкретного складу кримінального правопорушення, законодавець спирається на закріплені у нормах Загальної частини КК України ознаки кримінального пра- вопорушення, що мають загальний характер і входять до складу будь-якого кримінальне правопорушення. Наприклад, завжди враховуються закріплені в ст. ст. 18, 19 і 22 КК України вимоги до суб'єкта кримінального правопорушення (фізична, осудна особа, що досягла до моменту вчинення кримінального правопорушення визначеного законом віку). Тому під час конструювання конкретних кримінально-правових норм Особливої частини КК України уже відпадає необхідність щораз давати загальну характеристику суб'єкта кримінального правопорушення або в кожній окремій статті КК України розкривати зміст умислу і необережності, тому що зміст цих понять закріплено у ст. ст. 24 і 25 КК України. Підтримуємо позицію В.К. Матвійчука, що склад кримінального правопорушення $€$ універсальною юридичною конструкцією, за допомогою якої можна зробити кримінально-правову оцінку суспільно небезпечного діяння. Отже, склад кримінального правопорушення містить характеристику не якогось одного конкретного кримінального правопорушення, а всієї сукупності кримінальних правопорушень певного виду. Враховуючи зазначене, під час встановлення ознак конкретного складу кримінального правопорушення потрібно йти не шляхом їх ототожнення, а навпаки - через їх виявлення у вчиненому діянні і співставлення з елементами (ознаками) складу кримінального правопорушення, закріпленого в КК України. При цьому необхідно в конкретному діянні знайти юридично значущі об'єктивні та суб'єктивні ознаки, які характеризують його як кримінальне правопорушення. Відсутність якоїсь з юридично значущих ознак у діянні свідчить лише про відсутність у діянні особи конкретного складу кримінального правопорушення. Отже, під видовими ознаками складу кримінального правопорушення треба розуміти узагальнену юридично значиму якість, властиву всім кримінальним правопорушенням цього виду. Варто також погодитися з автором, що елементи складу кримінального правопорушення - однорідна група юридичних ознак, що характеризують кримінальне правопорушення як діяння (кримінальне правопорушення) з якогось одного боку. Як елементи складу кримінального правопорушення в кримінальному праві виділяють такі: об'єкт кримінального правопорушення, об'єктивну сторону складу кримінального правопорушення, суб'єктивну сторону складу кримінального правопорушення і суб'єкт складу кримінального правопо- 
рушення [2, с. 54]. І.П. Васильківська вважає, що склад кримінального правопорушення - це сукупність встановлених КК України об'єктивних і суб'єктивних ознак, які визначають конкретне суспільно небезпечне діяння як кримінальне правопорушення. Склад кримінального правопорушення - це єдина, необхідна і достатня підстава кримінальної відповідальності.

Кожний елемент складу кримінального правопорушення утворює певна сукупність ознак, які характеризують об'єкт та об'єктивну сторону, називають об'єктивними ознаками складу кримінального правопорушення, а ознаки, властиві суб'єкту й суб'єктивній стороні, - суб'єктивними ознаками. Усі ознаки, що входять до кожного елементу складу кримінального правопорушення, прийнято поділяти на дві групи: 1) обов'язкові (або необхідні) - притаманні будьякому складу кримінального правопорушення. Відсутність хоча б однієї з таких ознак свідчить про відсутність певного елементу складу кримінального правопорушення, а отже - самого складу кримінального правопорушення. До цієї групи, зокрема, належать такі ознаки суб'єкта кримінального правопорушення, як фрізична, осудна особа, досягнення нею віку кримінальної відповідальності. Обов'язковими ознаками, крім того, є діяння (характеризує об'єктивну сторону кримінального правопорушення), вина (належить до суб'єктивної сторони кримінального правопорушення); 2) фракультативні (тобто необов'язкові) - властиві окремим складам кримінального правопорушення. До фракультативних відносять час, місце, обстановку, знаряддя, засоби вчинення кримінального правопорушення та деякі інші ознаки об'єктивної сторони кримінального правопорушення; мотив, мету - ознаки, притаманні суб'єктивній стороні кримінального правопорушення; ознаки спеціального суб'єкта (громадянство, стать, службове становище) тощо. Поділ ознак на обов'язкові та фракультативні має сенс тільки на рівні загального поняття про склад кримінального правопорушення, а для конкретного складу кримінального правопорушення всі описані в законі ознаки - обов'язкові [5, с. 65-69].

В юридичній літературі $€$ й інші визначення поняття складу кримінального правопорушення, але всі вони переважно збігаються з раніше викладеними визначеннями поняття складу кримінального правопорушення. 3 усіх визначень поняття складу кримінального правопорушення найбільш конструктивний, як нам вважається, $€$ визначення, надане П.Л. Фрісом, тобто сукуп- ність визначених Кримінальним законом об'єктивних і суб'єктивних ознак, що характеризують відповідне суспільно небезпечно, протиправне, винне діяння (дію або бездіяльність) як кримінальне правопорушення. Проте, на нашу думку, поняття складу кримінального правопорушення треба викласти так: склад кримінального правопорушення - це сукупність, встановлених у законі про кримінальну відповідальність, об'єктивних і суб'єктивних ознак, що характеризують відповідне винне діяння (дію або бездіяльність) як кримінальне правопорушення. 3 аналізу розглянутих понять складу кримінального правопорушення неважко зробити висновок, що структура складу кримінального правопорушення складається з чотирьох елементів: об'єкта та об'єктивної сторони, суб'єкта та суб'єктивної сторони, Об'єкт кримінального правопорушення - це те, на що посягає кримінальне правопорушення діяння. Об'єктивна сторона кримінального правопорушення - його зовнішня сторона, яка виявляється у вчиненні передбаченого КК України діяння. Суб'єкт кримінального правопорушення - це особа, яка вчиняє кримінальне правопорушення. Суб'єктивна сторона кримінального правопорушення - внутрішня сторона суспільно небезпечного діяння; вона відображає процеси, що відбуваються у свідомості особи через вчинення нею кримінального правопорушення. Враховуючи все вище викладене, можна стверджувати, що в теорії кримінального права загальноприйнятим $€$ положення щодо того, що об'єктивна сторона кримінального правопорушення являє собою сукупність встановлених законом про кримінальну відповідальність ознак, які характеризують зовнішній прояв кримінального посягання. Тому чіткий опис ознак об'єктивної сторони досліджуваного кримінального правопорушення $\epsilon$ важливою передумовою дотримання законності у правозастосовній діяльності правоохоронних органів, оскільки притягнення особи до кримінальної відповідальності завжди пов'язане з встановленням у ії̈ поведінці конкретного суспільно небезпечного діяння, про яке йдеться в законі. Треба зазначити, що діяння завжди або безпосередньо вказується в диспозиції статті Особливої частини кримінального закону, або однозначно випливає з її змісту і, відповідно, є обов'язковою ознакою об'єктивної сторони кримінального правопорушення, а встановлення ознак такого діяння (дії чи бездіяльності) $є$ обов'язковим у кожному кримінальному впровадженні. 
За ст. 386 КК України встановлено відповідальність за кримінальне правопорушення із фрормальним складом, яке визнається закінченим із моменту вчинення однієї із зазначених у законі дій (перешкоджання чи примушування) незалежно від того, чи вдалося насправді перешкодити з'явленню свідка, потерпілого, експерта до слідчо-судових органів, примусити або схилити їх до відмови від давання чи до давання завідомо неправдивих показань або висновку. Поза межами складу кримінального правопорушення перебувають і дії, які $є$ фрактичною реалізацією тієї погрози, що висловлювалася винним, і які (за умови їх реального вчинення) підлягають самостійній кваліфікації.

Т.В. Варфоломеєва і $€$.В. Фесенко вважають, що з об'єктивної сторони це кримінальне правопорушення полягає у вчиненні дій у трьох альтернативно визначених у диспозиції ст. 386 КК України формах. Дві із зазначених форм становлять багатоактивну кримінальну поведінку. Зокрема, це такі дії: 1) перешкоджання з'явленню свідка, потерпілого або експерта до суду, органів досудового слідства, тимчасових слідчих і тимчасових спеціальних комісій ВРУ чи дізнання; 2) примушування цих осіб до відмови від давання показань чи висновку або давання завідомо неправдивих показань чи висновку. Автори уточнюють, що своєрідність таких дій полягає в тому, що вони (як перешкоджання, так і примушування) пов'язані із загрозою на адресу свідка, потерпілого або експерта чи їхніх близьких родичів або з підкупом таких осіб. При цьому погроза й підкуп виступають одночасно як дія і спосіб перешкоджання або примушування. Третьою фрормою вчинення цього кримінального правопорушення $\epsilon$ погроза вчинити зазначені дії через показання свідка або потерпілого чи висновок експерта, що були дані раніше. Якщо зазначене кримінальне правопорушення виявляється в перших двох формах, то вважається закінченим із моменту вчинення як перешкоджання або примушування, так і дій, що $є$ способом такого перешкоджання чи примушування, тобто погрози або підкупу. У разі, коли кримінальне правопорушення вчинено у третій фрормі, буде закінченим із моменту вчинення однієї дії - погрози [1, с. 471-472].

М.I. Мельниченко вважає, що об'єктивна сторона складу кримінального правопорушення, передбаченого у ст. 386 КК України, взагалі сконструйована вкрай невдало, що утруднює розуміння змісту цього кримінально-правового припису, а тому може спричинити труднощі під час кримінально-правової кваліфрікації. Насамперед це виявляється у нагромадженні в одній диспозиції статті чотирьох діянь, кожне з яких «ускладнене» іншими ознаками. А тому доводиться докладати зусиль для того, щоб зрозуміти, які з ознак описують ту чи іншу поведінку суб'єкта кримінального правопорушення. Окрім того, законодавець незрозуміло закріпив таке діяння, як підкуп, вказавши, що він вчиняється з тією самою метою, хоча в перших двох діяннях вона не визначена. Отже, встановити мету підкупу проблематично. Також незрозумілою $€$ вказівка в четвертому діянні про погрозу вчинити зазначені дії, а які саме дії - питання залишається відкритим. Авторові імпонує підхід законодавця тих держав, який передбачив аналогічні діяння в окремих частинах відповідних статей (КК Азербайджану, Вірменії, Грузії, Киргизії, Казахстану, Таджикистану, РФ) [8, с. 118-119]. В.І. Тютюгін стверджує, що об'єктивна сторона кримінального правопорушення, передбаченого ст. 386 КК України, полягає в активній поведінці особи - діях, що здійснюються в одній із таких форм: - перешкоджання з'явленню свідка, потерпілого чи експерта в органи досудового розслідування, до суду або до тимчасової слідчої комісії ВРУ (ст. 89 Конституції України); - примушування зазначених осіб до відмови від давання або до давання завідомо неправдивих показань чи висновку шляхом погрози вбивством, насильством, знищенням майна або розголошенням ганебних відомостей; - підкуп цих осіб із метою перешкоджання їх з'явленню до відповідних органів чи з метою їх схиляння до відмови від давання або до давання завідомо неправдивих показань чи висновку; - погроза вбивством, насильством, знищенням майна чи розголошенням ганебних відомостей щодо зазначених у ст. 386 КК України осіб за надані раніше показання чи висновок [8, с. 881-882]. Н.Ю. Алексєєва також уважає, що об'єктивна сторона кримінального правопорушення, передбаченого ст. 386 КК України, полягає в чотирьох формах: 1) перешкоджанні з'явленню свідка, експерта до суду, органів досудового слідства, тимчасової слідчої та спеціальної тимчасової слідчої комісій Верховної Ради України чи дізнання; 2) примушуванні свідка чи експерта до відмови від давання показань чи висновку, а також до давання завідомо неправдивих показань чи висновку шляхом погрози вбивством, насильством, знищенням майна цих осіб чи їхніх близьких родичів або розголошенням відомостей, що їх ганьблять; 
3) підкуп свідка чи експерта з метою відмови від давання показань чи висновку, а також до давання завідомо неправдивих показань чи висновку; 4) погрозі вчинити вбивство, насильство, знищення майна свідка, експерта чи їхніх близьких родичів або розголошення відомостей, що їх ганьблять, із помсти за раніше дані показання чи висновок [9, с. 330].

Усі вищевикладені трактування форм об'єктивної сторони кримінального правопорушення, передбаченого ст. 386 КК України, на нашу думку, не відповідають диспозиції цієї статті. У диспозиції ст. 386 КК України вказано, що перешкоджання з'явленню свідка, потерпілого, експерта до суду, органів досудового розслідування, тимчасових слідчих і спеціальної тимчасової слідчої комісії Верховної Ради України, примушування їх до відмови від давання показань чи висновку, а також до давання завідомо неправдивих показань чи висновку шляхом погрози вбивством, насильством, знищенням майна цих осіб чи їхніх близьких родичів або розголошенням відомостей, що їх ганьблять, або підкуп свідка, потерпілого чи експерта з тією самою метою, а також погроза вчинити зазначені дії з помсти за раніше дані показання чи висновок [3, с. 218].

Якщо зазначені в ст. 386 КК дії вчинюються щодо захисника чи представника особи, які надають правову допомогу, то залежно від конкретних обставин справи вчинене може бути кваліфіковане за статтями 397 або 398 КК. Якщо такі дії вчинюються щодо інших учасників процесу, вчинене може бути кваліфріковане за відповідними статтями, які передбачають відповідальність за кримінальне правопорушення проти життя, здоров'я чи власності або (за наявності до того підстав) - за ст. 350 КК.

Висновки і пропозиції. Аналізуючи вищевикладені позиції щодо кількості фрорм об'єктивної сторони кримінального правопорушення, передбаченого ст. 386 КК України, а також диспозицію цієї статті, видається можливим зробити висновок про те, що об'єктивна сторона складається з двох форм: 1) перешкоджання з'явленню свідка, потерпілого або експерта до суду, органів досудового слідства, тимчасових слідчих і тимчасових спеціальних комісій ВРУ чи дізнання; 2) примушування їх до відмови від давання показань чи висновку, а також до давання завідомо неправдивих показань чи висновку шляхом погрози вбивством, насильством, знищенням майна цих осіб чи їхніх близь- ких родичів або розголошенням відомостей, що їх ганьблять, або підкуп свідка, потерпілого чи експерта з тією самою метою, а також погроза вчинити зазначені дії з помсти за раніше дані показання чи висновок. Також можна окреслити таке: 1) об'єктивна сторона кримінального правопорушення, передбаченого ст. 386 КК України, характеризується активними діями; 2) об'єктивній стороні характерна ознака, як час його вчинення. Час вчинення кримінального правопорушення, передбаченого ст. 386 КК України, обмежується лише часом роботи досудового слідства, судового провадження, а також часом розслідування тимчасових слідчих і спеціальної тимчасової слідчої комісії Верховної Ради України, а інші будь-які рамки або обмеження в часі (певний проміжок часу, часовий період) не мають жодного значення для об'єктивної сторони кримінального правопорушення, передбаченого ст. 386 КК України.

\section{Список використаної літератури:}

1. Науково-практичний коментар до Кримінального кодексу України : у 2 т. / за заг. ред. П.П. Андрушка, В.Г. Гончаренка, Є.В. Фесенка. 3-тє вид., перероб. та доп. Київ : Алерта; КНТ: Центр учбової літератури, 2009. Т. 1. 964c.

2. Матвійчук В.К., Хар І.О. Кримінальне право України. Загальна частина: навч. посіб. Київ : КНТ, 2006. 432 с.

3. Кримінальний кодекс України. Київ : ПАЛИВОДА А.В., 2020. 264 с.

4. Фріс П.Л. Кримінальне право України. Загальна частина : підручник для студентів вищих навчальних закладів. Київ : Атіка, 2009. 512 с.

5. Васильківська І.П. Кримінальне право України. Загальна частина : навч. посіб. Київ : КНЕУ, 2013. 295 c.

6. Кудрявцев В.Н. Объективная сторона преступления. Москва : Госюриздат, 1960. 244 с.

7. Мороз А.О. Об'єктивна сторона кримінальне злочину втручання в діяльність захисника чи представника особи. Юридична наука. 2015. № 4. URK: http://nbuv.gov.ua/UJRN/ jnn_2015_4_7.

8. Мельниченко М.І. Кримінально-правова охорона порядку одержання доказів у кримінальному провадженні : дис. ... канд. юрид. наук : 12.00.08 / Інститут держави і права імені В.М. Корецького. Київ, 2016. 258 с.

9. Алєксєєва Н.Ю. Актуальні проблеми розмежування злочинів проти правосуддя, що вчиняються свідками, експертами, перекладачами або щодо них, від суміжних складів злочинів. Вісник Асоціації кримінального права України. 2014. № 2(3). С. 326-337. 


\begin{abstract}
Kovalenko D. A. Problem issues of the objective side of the criminal offense for obstacling the appearance of a witness, a victim expert, forcing them to refuse to give evidence or opinions

One of the main tasks of reforming the judicial system of Ukraine is the creation of an independent and effective judiciary, which is the guarantor of human rights and freedoms in Ukraine. At the same time, the commission of criminal offenses that infringe on justice can harm the order of public relations, which is protected by Chapter XVIII of the Special Part of the Criminal Code of Ukraine, which ensures the administration of fair justice, which guarantees effective restoration of rights. The composition of a criminal offense is the only, necessary and sufficient basis for criminal liability. Liability for a criminal offense under Art. 386 of the Criminal Code of Ukraine consists of two forms: 1) obstruction of the appearance of a witness, victim or expert in court, pre-trial investigation bodies, temporary investigators and temporary special commissions of the Verkhovna Rada or inquiry; 2) forcing them to refuse to testify or report, as well as to give knowingly false testimony or opinion by threatening to kill, violence, destroying the property of these persons or their close relatives or disclosing information that discredits them, or bribing a witness, victim or expert. the same purpose, as well as the threat to take these actions in retaliation for previously given testimony or conclusion. A criminal offense is recognized as completed from the moment of committing one of the actions specified in the law (obstruction or coercion), regardless of whether it was possible to prevent the appearance of a witness, victim, expert in the investigative and judicial bodies, to force or persuade them to refuse to give or to giving knowingly false testimony or conclusion. But outside are actions that are the actual implementation of the threat expressed by the perpetrator, and which (subject to their actual commission) are subject to independent qualification. The objective side of the criminal offense under Art. 386 of the Criminal Code of Ukraine, is characterized by active actions, and the time is limited only to the time of pre-trial investigation, court proceedings, as well as the investigation of temporary investigators and special temporary commission of inquiry of the Verkhovna Rada of Ukraine, and any other time frame or time limit. , time period) have no significance for the objective side of the criminal offense under Art. 386 of the Criminal Code of Ukraine.
\end{abstract}

Key words: obstruction, appearance, coercion, witness, victim, expert, refusal, testimony. 


\title{
КРИМІНАЛЬНИЙ ПРОЦЕС ТА КРИМІНАЛІСТИКА; СУДОВА ЕКСПЕРТИЗА
}

УДК 343.1

DOI https://doi.org/10.32840/1813-338X-2020.3.21

\begin{abstract}
Ю. П. Аленін
доктор юридичних наук, профресор, член-кореспондент

Національної академії правових наук України, профресор кафредри кримінального процесу, детективної та оперативно-розшукової діяльності Національного університету «Одеська юридична академія»
\end{abstract}

O. O. Торбас

кандидат юридичних наук, доцент кафедри кримінального процесу, детективної та оперативно-розшукової діяльності Національного університету «Одеська юридична академія»

\section{СПІВВІДНОШЕННЯ ПРОЦЕСУАЛЬНОЇ САМОСТІЙНОСТІ ТА РОЗСУДУ СЛІДЧОГО У КРИМІНАЛЬНОМУ ПРОЦЕСІ УКРАЇНИ}

Кримінальне прочесуальне законодавство України надає слідчому досить широкі прочесуальні можливості, які потрібні для проведення ефективного досудового розслідування. При цьому в деяких випадках слідчий може застосовувати такі повноваження на власний розсуд. Однак такий розсуд слідчого не є абсолютним, адже він обмежений як правовими нормами, так і поведінкою інших учасників кримінального процесу Відповідно, розсуд слідчого досить тісно пов'язаний з його процесуальною самостійністю, яка також гарантується кримінальним процесуальним законодавством.

У статmі автори зазначають, що процесуальна самостійність і розсуд - поняття нетотожні, проте наявний міцний зв'язок між ними. 3 аналізу сутності процесуальної самостійності слідчого можна зробити висновок, що розсуд розглядається як один із способів реалізації самостійності. Процесуальна самостійність слідчого розглядається як елемент процесуального статусу слідчого, що дає йому змогу ухвалювати юридично значущі рішення та визначати хід всього досудового розслідування (у межах, встановлених кримінальним процесуальним законодавством). Відповідно, процесуальна самостійність передбачає цілий комплекс повноважень слідчого, а не лише конкретне повноваження. Розсуд, у свою чергу, передбачає можливість ухвалення конкретного процесуального рішення (або вчинення конкретної процесуальної дії) в конкретній ситуації, обираючи з декількох альтернатив. Отже, процесуальна самостійність є поняттям ширшим, ніж розсуд слідчого. Процесуальна самостійність передбачає можливість обрати необхідну сукупність процесуальних дій, які, на думку слідчого, дадуть змогу досягнути кінцевої мети розслідування. Розсуд, у свою чергу, стосується способу та методу проведення конкретної процесуальної дії. Водночас у статmі робиться висновок, що зв'язок між розсудом і процесуальною самостійністю слідчого не є одностороннім.

Отже, незважаючи на те, що розсуд є механізмом реалізації процесуальної самостійності, власне обсяг розсуду і фоормує обсяг такої самостійності. Чим більше повноважень, за яких слідчий може застосовувати розсуд, тим ширшою є процесуальна самостійність такого слідчого.

Ключові слова: процесуальна самостійність слідчого, розсуд слідчого. 
Постановка проблеми. Слідчий $€$ одним із ключових учасників кримінального провадження. Крім того, слідчий уповноважений на прийняття юридично значущих рішень, які суттєво впливають на хід кримінального провадження. I з урахуванням того факту, що законодавець не визначив чітких інструкцій розслідування кожного конкретного кримінального правопорушення, слідчий застосовує власні дискреційні повноваження в кожному кримінальному провадженні, яке ним розслідується. Однак такий розсуд слідчого не є абсолютним, адже він обмежений як правовими нормами, так і поведінкою інших учасників кримінального процесу (в першу чергу - через вказівки та доручення прокурора). Відповідно, розсуд слідчого досить тісно пов'язаний з його процесуальною самостійністю, яка також гарантується кримінальним процесуальним законодавством. В той же час можна констатувати відсутність комплексного дослідження співвідношення процесуальної самостійності та розсуду слідчого у кримінальному процесі.

Аналіз останніх досліджень і публікацій. Проблематикою процесуальної самостійності та розсуду слідчого переймалися такі вітчизняні та зарубіжні вчені, як О.В. Баулін, А.П. Гуляев, О.О. Кіпер, А.А. Клейн, А.М. Ларін, А.О. Ляш, П.Г. Марцифин, Д.І. Пишньов, С.М. Смоков та інші. Проте в доктрині відсутнє наукове дослідження, в якому би порівнювались ці два поняття між собою, що і підкреслює актуальність даного дослідження.

Метою статті $€$ встановлення та описання зв'язку між процесуальною самостійністю та розсудом слідчого.

Виклад основного матеріалу. П.Г. Марфицин, розглядаючи розсуд слідчого, дійшов висновку, що в основі такого розсуду лежить внутрішнє переконання. При цьому автор, розуміючи важливість будь-якого суб'єктивного фактору в процесі формування розсуду, вказує на недоцільність ототожнення цих двох понять, оскільки внутрішнє переконання «має місце за повної відсутності встановлених правових критеріїв і застосовується в законі щодо оцінки доказів, а не встановлення за їхньою допомогою фактичних обставин» [1, с. 115]. В цьому випадку необхідно зауважити, що розсуд слідчого (як і будь-якого іншого уповноваженого суб'єкта кримінальних процесуальних відносин) значною мірою покладається саме на внутрішнє переконання, однак визнавати цю категорію фундаментальною в цьому випадку не зовсім правильно. По-перше, будь-який законний роз- суд має бути обмеженим, адже необмежений розсуд тягне за собою свавілля уповноваженого на його застосування суб'єкта. Відповідно, вказувати на фундаментальність внутрішнього переконання при застосуванні розсуду, забуваючи при цьому нормативні межі такого розсуду, некоректно. По-друге, розсуд може бути помилковим (особливо якщо мова йде про копіювання власної поведінки або поведінки інших суб'єктів). В такому випадку уповноважені на те суб'єкти також в якості фундаментальної константи будуть використовувати внутрішнє переконання, проте таке переконання також буде хибним, а сам правозастосувач не спроможний відповідним чином скорегувати власну поведінку. Тому, не применшуючи значення будь-яких суб'єктивних факторів в процесі формування розсуду, вказувати на внутрішнє переконання як на певний базис не зовсім правильно.

А.Б. Ярославський, досліджуючи розсуд слідчого, окремо визначає оптимальний та безпосередній розсуд слідчого. Оптимальний розсуд проявляється в наступних різновидах: 1) надання слідчому права обирати один з передбачених відповідною правовою нормою варіантів поведінки або рішення; 2) надання слідчому права приймати в процесі розслідування злочинів рішень, які базуються на формулюваннях норм, що регламентують його діяльність шляхом таких загальних фрормулювань, як «слідчий має право», «слідчий може», за якими слідує перелік умов, за яких відповідне рішення буде найбільш доцільним; 3) можливість приймати певне рішення на підставі формулювання «за потреби», «за нагальної потреби» тощо; 4) необхідність застосування аналогії права.

Безпосередній же розсуд слідчого пов'язаний в першу чергу з його професійною трансорормацією. Такий розсуд відрізняється від оптимального певними змінами в особистісних характеристиках слідчого [2, с. 30].

У цьому випадку науковець узяв за основу фактори, що впливають на розсуд (об'єктивні та суб'єктивні), та на підставі цього сформулював окремі види розсуду. I хоча такий підхід, враховуючи позицію автора, можна вважати виправданим, повністю погодитись з ним складно. Дійсно, якщо стверджувати, що на розсуд слідчого впливають лише об'єктивні фактори, то такий розсуд можна вважати «оптимальним». При цьому науковець стверджує, що оптимальний розсуд слідчого на практиці зустрічається, хоча і досить рідко. Однак більш логічною виглядає позиція, відповідно до якої «оптимальний» розсуд, запропонований науковцем, 
на практиці взагалі не існує. Це пояснюється в першу чергу неможливістю не враховувати суб'єктивні чинники в процесі застосування розсуду. Розсуд може реалізуватися тільки людьми, які в кримінальному процесі обіймають певні посади та відповідно до них виконують певні повноваження. Але в будь-якому випадку рішення приймається людиною, а тому ігнорувати суб'єктивні фрактори розсуду буде нелогічно. Необхідно констатувати складність оцінки суб'єктивних факторів та сили їх впливу на прийняте уповноваженою особою рішення, проте складність такого аналізу не є підставою для ігнорування відповідних факторів.

Власне, аналізуючи особливості розсуду слідчого, насамперед необхідно звернути увагу на свободу у його застосуванні. Будьякий розсуд у кримінальному процесі обмежений нормативними вказівками, обставинами конкретного кримінального провадження тощо. Водночас судді та прокурори наділені відносною свободою у реалізації власного розсуду. Якщо ж вести мову про слідчого, то в цьому випадку рівень такої свободи дещо вужчий. Необхідно акцентувати увагу на роль прокурора в якості процесуального керівника за діяльністю слідчого на стадії досудового розслідування, адже всі юридично значущі рішення та майже всі процесуальні дії мають бути в тій чи іншій фооммі затверджені прокурором. Відповідно, розсуд слідчого також у певній формі має бути погоджений прокурором. Свобода слідчого у застосуванні розсуду напряму залежить від обсягу процесуальної самостійності слідчого, яка визначена кримінальним процесуальним законодавством.

Зараз питання процесуальної самостійності слідчого досить активно досліджується науковцями. Досліджуючи процесуальну самостійність та незалежність слідчого, частина науковців стверджує, що ці поняття є тотожними [3, с. $37 ; 4$, с. $121-135 ; 5]$. Інша група науковців підтримує позицію, що процесуальної незалежності взагалі не існує, адже вона суперечить концепції прокурорського нагляду за досудовим розслідуванням [6, с. $58 ; 7$, с. 10]. Між цими двома діаметрально протилежними концепціями виникла третя, в якій об'єднані найкращі положення попередніх двох. Автори такого підходу розглядали процесуальну незалежність слідчого як самостійну категорію науки кримінального процесу з характерними ознаками, що відрізняють її від процесуальної самостійності слідчого $[8$, с. 8] або взагалі окремо досліджували самостійність процесуальних рішень слід- чого та незалежність його як процесуального учасника кримінального процесу [9, с. 50]. Очевидно, що кожен із запропонованих підходів може бути взятий за основу, адже в правовій доктрині можна знайти обґрунтування кожної із даних позицій. Тому, задля подальшої уніфрікації даного дослідження, пропонується в першу чергу врахувати положення кримінального процесуального законодавства. Так, відповідно до ч. 5 ст. 40 КПК України, слідчий, здійснюючи свої повноваження відповідно до вимог КПК України, $є$ самостійним у своїй процесуальній діяльності. Таким чином законодавець підштовхує до використання терміна «процесуальна самостійність слідчого» під час аналізу ролі цього учасника кримінального провадження в кримінальному процесі. Тому пропонується використовувати саме дане формулювання. Крім того, значення має не саме формулювання, а зміст, який в нього вкладається.

Вчені, досліджуючи сутність процесуальної самостійності слідчого, аналізували відповідну правову категорію в першу чергу через обсяг повноважень, якими наділений слідчий у кримінальному процесі. Г.М. Ясинський стверджує, що процесуальна самостійність слідчого полягає в праві вирішувати за своїм внутрішнім переконанням, що базується на матеріалах справи, і у відповідності до закону найважливіші питання слідства [10, с. 64]. А.А. Клейн, досліджуючи правовий статус слідчого, стверджує, що процесуальна самостійність слідчого $\epsilon$ важливою частиною його процесуального статусу, що полягає в праві самостійно приймати всі рішення про хід слідства та провадження слідчих дій та в повній відповідальності за їх законне та вчасне проведення [11, с. 14]. О.О. Кіпер дійшов висновку, що процесуальна самостійність слідчого має розглядатися нерозривно 3 основними засадами кримінального провадження. Відповідно до позиції автора, під процесуальною самостійністю слідчого слід розуміти загальне положення досудового розслідування, що є засобом реалізації принципу всебічного, повного та неупередженого встановлення обставин кримінального провадження, яке полягає у повноваженні слідчого самостійно на підставі свого внутрішнього переконання та керуючись законом, починати досудове розслідування, визначати напрямки розслідування, приймати відповідні процесуальні рішення та вчиняти дії, пов'язані із розслідуванням кримінального правопорушення, за винятком випадків, коли законом передбачене отримання на це згоди (рішення) прокурора, 
керівника органу досудового розслідування чи дозволу слідчого судді, визначати порядок і послідовність проведення цих процесуальних дій та нести повну відповідальність за їх законне і своєчасне проведення (застосування), а також відстоювати (захищати) ці повноваження, передбаченими КПК засобами [12, с. 81].

Отже процесуальна самостійність слідчого нерозривно пов'язана з можливістю реалізації повноважень слідчого у кримінальному провадженні. Свобода, з якою такі повноваження можуть бути реалізовані, являється визначальною характеристикою цього поняття. При цьому значна частина вчених, аналізуючи процесуальну самостійність слідчого, згадує розсуд як спосіб ії реалізації. Цим ще раз підтверджується досить тісний зв'язок цих двох категорії. Однак такий зв'язок вказує на необхідність встановлення чітких меж між процесуальною самостійність слідчого та його розсудом.

Очевидно, що процесуальна самостійність та розсуд - поняття нетотожні, однак досить легко помітити вплив одного поняття на інше. 3 аналізу сутності процесуальної самостійності слідчого можна зробити висновок, що розсуд розглядається як один із способів реалізації самостійності. В цілому процесуальна самостійність слідчого розглядається як елемент процесуального статусу слідчого, що дає йому змогу ухвалювати юридично значущі рішення та визначати хід усього досудового розслідування (у межах, встановлених кримінальним процесуальним законодавством). Отже, процесуальна самостійність передбачає цілий комплекс повноважень слідчого, а не лише конкретне повноваження. Розсуд, в свою чергу, передбачає можливість прийняття конкретного процесуального рішення (або вчинення конкретної процесуальної дії) в конкретній ситуації, обираючи з декількох альтернатив. Тож можна дійти висновку, що процесуальна самостійність $€$ поняттям ширшим, ніж розсуд слідчого. Процесуальна самостійність передбачає можливість обрати необхідну сукупність процесуальних дій, які, на думку слідчого, дозволять досягнути кінцеву мету розслідування. Розсуд, у свою чергу, стосується способу та методу проведення конкретної процесуальної дії. За такого підходу можна зробити висновок, що розсуд можна розглядати в якості механізму реалізації процесуальної самостійності слідчого, який стосується способу реалізації відповідних повноважень.

Водночас необхідно зробити висновок, що зв'язок між розсудом та процесуальною самостійністю слідчого не є одностороннім. Тобто, незважаючи на те, що розсуд $є$ механізмом реалізації процесуальної самостійності, власне обсяг розсуду і формує обсяг такої самостійності. Як вже було зазначено, розсуд $є$ механізмом реалізації процесуальної самостійності слідчого. Водночас власне повноваження, які можуть бути реалізовані із застосуванням розсуду, і визначають обсяг процесуальної самостійності. Чим більше повноважень, за яких слідчий може застосовувати розсуд, тим ширшою є процесуальна самостійність такого слідчого. Відповідно, дослідження розсуду слідчого також напряму пов'язано з межами його процесуальної самостійності.

О.О. Кіпер зазначає, що межами процесуальної самостійності слідчого є певні обмеження самостійних прав слідчого при провадженні досудового розслідування [12, с. 95]. При цьому науковець, досліджуючи це питання, більшою мірою приділяє увагу тим посадовим особам, які власне обмежують процесуальну самостійність слідчого: прокурор, керівник органу досудового розслідування, слідчий суддя, та робить висновок про те, що у порівнянні з попереднім кримінальним процесуальним законодавством процесуальна самостійність слідчого зазнала значного звуження. «Таке звуження самостійних повноважень слідчого у прийняття процесуальних рішень часом шкодить ефективному розслідуванню і призводить до затягування строків досудового розслідування, оскільки для того, щоб вчинити більшість процесуальних дій, він повинен отримувати згоду або рішення прокурора, який здійснює нагляд за досудовим розслідуванням та дозвіл слідчого судді, або повідомляти про їх вчинення, що відволікає його від виконання своєї прямої та основної функції фрункції розслідування кримінального правопорушення» [12, с. 98].

Щодо цього А.О. Ляш та О.В. Баулін зазначали, що ігнорування позитивного досвіду, набутого і апробованого за часів дії КПК 1960 р., з прийняттям нового КПК призвело до остаточної втрати слідчим залишків своєї процесуальної незалежності, а їхня процесуальна самостійність стала мінімально можливою і фактично наблизилася до процесуальної самостійності колишнього дізнавача органу дізнання [13, с. 4]. Підсумовуючи позиції більшості вчених, необхідно констатувати, що однією з визначальних характеристик розсуду слідчого є обмеженість такого розсуду іншими уповноваженими суб'єктами кримінального процесу - прокурором, слідчим суддею, керівником органу досудового розслідування. Поєднання обмежень процесу- 
альної самостійності та незалежності у розв'язанні низки процесуальних питань і виділяє розсуд слідчого з-поміж розсуду інших учасників кримінального провадження - слідчого судді, суду, прокурора. Низка процесуальних рішень прокурора також має бути погоджена з іншими учасниками процесу (наприклад, погодження зміни обвинувачення в суді з прокурором вищого рівня), однак такі обмеження не мають систематичного характеру та більше спрямовані на додаткове забезпечення прав та законних інтересів учасників кримінального провадження. Діяльність слідчого, в свою чергу, нерозривно пов'язана з процесуальним керівництвом з боку прокурора, адже навіть будь-яке звернення до слідчого судді потребує погодження з процесуальним керівником. Відповідно, застосування слідчим розсуду в процесі прийняття юридично значимих рішень обов'язково тягне за собою контроль з боку прокурора, який, керуючись власним розсудом, погоджує або відмовляє в погодженні відповідних рішень чи клопотань.

Говорячи про процесуальну самостійність слідчого, також необхідно зазначити, що кримінальне процесуальне законодавство надало можливість слідчому не погодитись з позицією прокурора щодо найбільш важливих питань під час досудового розслідування. При цьому законодавець встановлює дві відносно окремі процедури оскарження слідчим рішень прокурора. Так, згідно з ч. 3 ст. ст. 40 КПК України, у випадках відмови прокурора у погодженні клопотання слідчогодо слідчого судді про застосування заходів забезпечення кримінального провадження, проведення слідчих (розшукових) дій чи негласних слідчих (розшукових) дій слідчий має право звернутися до керівника органу досудового розслідування, який після вивчення клопотання за необхідності ініціює розгляд питань, порушених у ньому, перед прокурором вищого рівня, який протягом трьох днів погоджує відповідне клопотання або відмовляє у його погодженні. Крім того, в параграфр 3 Глави 26 КПК України окремо присвячений порядку оскарження слідчим рішень, дій чи бездіяльності прокурора.

Спершу необхідно встановити, чим ці дві процедури відрізняються між собою, адже процедури оскарження в даному випадку досить подібні. Аналізуючи положення ст. 40 та ст.ст. 311-313 КПК України, можна встановити одразу декілька відмінностей. Першою відмінністю $€$ предмет оскарження. Відповідно до ст. 311 КПК України, слідчий має право оскаржувати будь-які рішення, дії чи бездіяльність прокурора, прийняті або вчинені під час досудового розслідування, крім випадків, передбачених кримінальним процесуальним законодавством. В свою чергу, в ст. 40 КПК України ведеться мова про оскарження відмови прокурора у погодженні клопотання слідчого про застосування заходів забезпечення кримінального провадження, проведення слідчих та негласних слідчих (розшукових) дій. I хоча таку відмову прокурора можна розглядати як рішення, документально вона не оформлюється в порядку, передбаченому ст. 110 КПК України.

Відмінності також наявні і в самій процедурі оскарження. Відповідно до ст. 40 КПК України, слідчий може оскаржити відмову прокурора у погоджені відповідних клопотань до прокурора вищого рівня, проте через керівника органу досудового розслідування. Оскарження рішень, дій та бездіяльності прокурора в порядку § 3 Глави 26 КПК України відбувається напряму до прокурора вищого рівня. Власне сутність таких відмінностей у процедурі оскарження законодавцем не роз'яснені. Це дає змогу науковцям робити висновок, що ст. 40 КПК України надає слідчому право на звернення до керівника органу досудового розслідування у випадках, визначених законодавством [14, с. 125-126], відповідно, підкреслюючи перевагу відомчого контролю над контролем прокурора вищого рівня у випадку відмови у затверджені відповідних клопотань. I хоча така позиція дійсно в певній мірі ґрунтується на положеннях кримінального процесуального законодавства, повністю з нею погодитись не можна.

Відповідно до ч. 3 ст. 40 КПК України, слідчий має звернутися до керівника органу досудового розслідування, який після вивчення клопотання за необхідності ініціює розгляд питання, порушених у ньому, перед прокурором вищого рівня. Відповідно, саме керівник органу досудового розслідування вирішує, які клопотання будуть надіслані до прокурора вищого рівня, а які - ні. Якщо провести аналогію, то в даному випадку роль керівника органу досудового розслідування подібна до ролі ВССУ при поданні заяви про перегляд до Верховного Суду України в попередніх редакціях КПК України 2012 року. Проблема полягає в тому, що законодавець, на відміну від положень, які стосувалися ВССУ, не встановлює, що саме має перевірити керівник органу досудового розслідування, коли до нього звертається слідчий. Можна спрогнозувати, що керівник в першу чергу перевіряє обґрунтованість такого клопотання. Для цього йому необхідно буде ознайомитись 3 матеріалами досудового розслідування та вислухати 
обґрунтування самого слідчого. Якщо керівник дійде висновку, що клопотання слідчого $€$ обґрунтованим, то він зобов'язаний передати відповідне клопотання прокурору вищого рівня. За такої процедури керівника органу досудового розслідування можна вважати свого роду «процесуальним фрільтром2, який забезпечує отримання прокурором вищого рівня лише обґрунтованих клопотань від слідчого. Проте кінцеве рішення ухвалює саме прокурор. 3 огляду на це позиція науковців, яка була озвучена вища, щодо визначення керівника органу досудового розслідування як основного суб'єкта вирішення клопотання слідчого в порядку ч. 3 ст. 40 КПК України, є передчасною.

Водночас не зовсім зрозуміла логіка законодавця, який встановив обов'язковою участь керівника органу досудового розслідування в процесі оскарження клопотань слідчим в порядку ч. 3 ст. 40 КПК України, однак не передбачив такого порядку в § 3 Глави 26 КПК України, які по суті $\epsilon$ між собою досить подібними. Відповідно, така неоднорідність правового регулювання подібних за формою та змістом правових процедур підштовхує до думки, що в цій частині кримінальне процесуальне законодавство має бути уніфіковане - або участь керівника органу досудового розслідування має бути передбачена в усіх випадках, коли слідчий не погоджується 3 позицією процесуального керівника, або взагалі такого суб'єкта в даному процесі не повинно бути. I саме відсутність чіткої вказівки на роль керівника органу досудового розслідування в даному процесі підштовхує до обрання другого варіанту із запропонованих. Законодавець, закріпивши в ч. 3 ст. 40 КПК України участь керівника органу досудового розслідування в процесі подання клопотання слідчого до прокурора вищого рівня, власне не зазначив, чим саме пояснюються такі обмеження та яка має бути від них процесуальна користь. Можна було б зробити припущення, що таким чином законодавець намагається зменшити кількість клопотань слідчого, які надходять до прокурора вищого рівня, відсікаючи ще на початковому етапі очевидно необґрунтовані. Однак у такому разі можна навести одразу декілька контраргументів. По-перше, в § 3 Глави 26 КПК України передбачена процедура оскарження слідчим рішень, дій чи бездіяльності прокурора без участі керівника органу досудового розслідування, а тому не можна стверджувати, що його роль в даному процесі $\epsilon$ критично важливою. По-друге, випадки звер- нення слідчого до керівника органу досудового розслідування $є$ поодинокими, а тому не можна стверджувати, що має існувати будь-який процесуальний «фрільтр».

Отже, можна зробити висновок, що роль керівника органу досудового розслідування в процесі направлення клопотання слідчим до прокурора вищого рівня як мінімум невиправдана. Цей фракт також підтверджується тією обставиною, що законодавець не надав чітких вказівок щодо участі керівника органу досудового розслідування в даному процесі. У зв'язку з цим, з метою уніфікації положень КПК України, пропонується внести зміни до ч. 3 ст. 40 КПК України та виключити положення, які стосуються участі керівника органу досудового розслідування. У такому разі ч. 3 ст. 40 КПК України може бути сформульована наступним чином: «3. У випадках відмови прокурора у погодженні клопотання слідчого до слідчого судді про застосування заходів забезпечення кримінального провадження, проведення слідчих (розшукових) дій чи негласних слідчих (розшукових) дій слідчий має право звернутися до прокурора вищого рівня, який протягом трьох днів погоджує відповідне клопотання або відмовляє у його погодженні». В такому випадку буде забезпечена однаковість нормативно-правового регулювання положень кримінального процесуального закону в частині, що регулює оскарження слідчим рішень, дій, бездіяльності прокурора або його відмову у погодженні клопотань, які передбачені ч. 3 ст. 40 КПК України.

Висновки. Підсумовуючи все вищезазначене, можна зробити наступні висновки: 1) поняття «процесуальна самостійність» і «розсуд" слідчого тісно між собою пов'язані, проте не $є$ тотожними. Найбільш виваженою виглядає позиція, відповідно до якої розсуд є механізмом реалізації процесуальної самостійності слідчого, який стосується способу реалізації відповідних повноважень слідчого; 2) зв'язок між процесуальною самостійністю та розсудом слідчого є двостороннім. Розсуд розглядається як механізм реалізації процесуальної самостійності, при цьому чим частіше слідчий у своїй діяльності може застосувати розсуд, тим ширшою $€$ його процесуальна самостійність; 3) 3 метою уніфікації положень КПК України пропонується ч. 3 ст. 40 КПК України викласти в наступній редакції: «3. У випадках відмови прокурора у погодженні клопотання слідчого до слідчого судді про застосування заходів забезпечення кримінального провадження, проведення слідчих (розшукових) дій чи негласних 
слідчих (розшукових) дій слідчий має право звернутися до прокурора вищого рівня, який протягом трьох днів погоджує відповідне клопотання або відмовляє у його погодженні».

\section{Список використаної літератури:}

1. Марфицин П.Г. Усмотрение следователя (Уголовно-процессуальный аспект): дис.. ... докт. юрид. наук: 12.00.09. Омск, 2003. 418 с.

2. Ярославский А.Б. Усмотрение следователя при расследовании уголовных дел: дис. .. канд. юрид. наук: 12.00.09. Волгоград, 2001. $160 \mathrm{C}$.

3. Гуляев А.П. Следователь в уголовном процессе: Учебн. Пособие. М.: Юрид. лит., 1981. 191 с.

4. Слинько С.В. Механизм реализации процессуального статуса субъектов уголовно-процессуальной деятельности: монография. Х.: Основа, 2005. 254 с.

5. Пишньов Д.І. Процесуальні питання щодо розроблення законодавчих актів зі створення слідчого комітету. Засади кримінального судочинства та їх реалізація в законотворчій $i$ правозастосовній діяльності: тези доп. та повідомл. наук.-практ. конфр. (Київ, 3 квітня 2009 р.). К.: Атіка, 2009. С. 320-322.

6. Рахунов Р.Д. Учасники уголовно-процессуальной деятельности: Учеб. пособие. М.: Гос.юриздат., 1961. 277 с.
7. Смоков С.М. Внутрішнє переконання слідчого і його роль при прийнятті процесуальних рішень: автореф. дис... канд. юрид. наук. К., 2002. 19 с.

8. Клейн А.А. Правовые и организационные аспекты процессуальной самостоятельности и независимости следователя органов внутренних дел: автореф. дис. ... канд. юрид. наук. М., 1992. $26 \mathrm{c}$.

9. Ларин А.М. Следствие: каким ему быть? Человек и закон. 1996. № 10. С. 50-55.

10.Ясинский Г. М. О процессуальной самостоятельности следователя. Сов. государство и право. 1964. № 9. С. 64-73.

11. Клейн А. А. Правовые и организационные аспекты процессуальной самостоятельности и независимости следователя органов внутренних дел : дис. ... канд. юрид. наук. М., 1992. 217 с.

12. Кіпер О.О. Процесуальна самостійність слідчого якгарантія всебічного, повногой неупередженого розслідування у кримінальному провадженні: дис. ... канд. юрид. наук. Одеса, 2017. 240 с.

13.Ляш А.О., Баулін О.В. Процесуальна самостійність і незалежність слідчого за новим КПК України. Часопис Академії адвокатури України. 2013. № 18. URL: http//://e-pub.aau.edu.ua/ index.php/chasopys/article/download/167/18.

14.Кримінальний процес: підруч. / Ю.М. Грошевий, В.Я. Тацій, В.П. Пшонка та ін.; за заг. ред. В.Я. Тація, В.П. Пшонки. Х.: Право, 2013. 824 с.

\section{Alenin Yu. P., Torbas O. O. Interrelation between procedural independence and discretion of investigation in the criminal process of Ukraine}

Criminal procedure legislation of Ukraine provides investigator with a wide range of procedural opportunities required for an effective pre-trial investigation. However, in some cases, investigator may exercise such powers at his own discretion. Such discretion of investigator is not absolute, as it is limited by both legal norms and behavior of other participants in criminal proceedings. Accordingly, discretion of investigator is closely related to his procedural independence, which is also guaranteed by criminal procedure law.

In the article, authors note that procedural independence and discretion are not identical concepts, but there is a strong connection between them. From the analysis of the essence of procedural independence of investigator it can be concluded that discretion is considered as one of the ways to realize such independence. Procedural independence of investigatoris considered as an element of his procedural status, which allows him to make legally significant decisions and determine the course of entire pre-trial investigation (within the limits established by criminal procedural law). Thus, procedural independence presupposes a whole set of powers of investigator, not only a specific power. Discretion provides the possibility of making a specific procedural decision (or committing a specific procedural action) in a particular situation, choosing from several alternatives. Thus, procedural independence is a broader concept than investigator's discretion. Procedural independence provides an opportunity to choose necessary set of procedural actions, which, in the opinion of the investigator, will help to achieve the ultimate goal of investigation. Discretion concerns the manner and method of carrying out a particular procedural action. At the same time, the article concludes that connection between discretion and procedural independence of the investigator is not one-sided.

Thus, despite the fact that discretion is a mechanism for the implementation of procedural independence, the actual scope of discretion forms scope of procedural independence. The bigger number of powers under which investigator may exercise discretion - the greater his procedural independence.

Key words: procedural independence of investigator, discretion of investigator. 
УДК 343.1:070

DOI https://doi.org/10.32840/1813-338X-2020.3.22

\section{С. 3. Булик-Верхола}

кандидат фрілологічних наук, доцент, доцент кафедри української мови Національного університету «Львівська політехніка»

А. О. Верхола

студентка юридичного фракультету Львівського національного університету імені Івана Франка

\section{ОСОБЛИВОСТІ КРИМІНАЛЬНОГО ПРОЦЕСУАЛЬНОГО ЗАХИСТУ ПРЕСИ В УКРАЇНІ}

У статті проаналізовано особливості кримінального прочесуального захисту преси в Україні: з'ясовано такі механізми захисту журналістських джерел, як «свідоцький імунітет журналіста» та «тимчасовий доступ до речей і документів та обшук у приміщенні, де проживає та/чи працює журналіст»; охарактеризовано питання залучення журналістів до консріденційного співробітництва; розглянуто принцип гласності й відкритості судового провадження та повного фріксування технічними засобами судового засідання і процесуальних дій, а саме щодо переважного права журналістів перебувати в залі судового засідання.

Свідоцький імунітет журналіста дає змогу не давати показання, які можуть викрити журналістські джерела. У разі відмови від надання зазначеної інформації журналіста не можна притягнути до кримінальної відповідальності. Однак щодо тих питань, які не стосуються його професійної діяльності, журналіста можна допитувати без застережень. У цьому разі не йдеться про здійснення профресійної діяльності, тому він мусить давати показання, а за відмову нестиме кримінальну відповідальність.

Тимчасовий доступ до речей і документів - це надання стороні кримінального провадження особою, у володінні якої є такі речі і документи, можливості ознайомитися з ними, зробити їхні копії чи вилучити їх. Проте охоронюваною законом таємницею, що міститься в речах і документах, є, зокрема, інформація, що перебуває у володінні засобів масової інфрормації або журналістів, надана їм за умови нерозголошення авторства чи джерела інформації. Тому журналіст має право на збереження таємниці авторства та джерел інфрормації, за винятком випадків, коли ці таємниці оприлюднюються на вимогу суду.

Однією з основних засад судочинства, визначених ст. 129 Конституції України, є гласність судового провадження та повне фріксування технічними засобами судового засідання й прочесуальних дій. Крім того, Міжнародним пактом про громадянські і політичні права та Конвенцією про захист прав людини й основоположних свобод, які є частиною національного законодавства, проголошено, що кожен, кому пред'явлено обвинувачення у вчиненні кримінального правопорушення, має право на справедливий, публічний розгляд його справи незалежним і безстороннім судом.

Ключові слова: права журналістів, захист журналістських джерел, свідоцький імунітет журналіста, конфріденційне співробітництво, свобода інформації, принцип гласності і відкритості судового провадження та повного фріксування технічними засобами судового засідання і процесуальних дій.

Постановка проблеми. Право на свободу слова - одне з основних прав людини, яке має забезпечувати демократична країна. Для реалізації цього права необхідно створити безпечні умови діяльності засобів масової інфрормації та журналістів, які $\epsilon$ на сторожі демократії. Працівники ЗMІ мають уміти відстоювати це право, адже робота журналістів у світі та в Україні зокрема сповнена загроз.
За статистикою Департаменту комунікації MBC, «за п'ять місяців 2019 року слідчі підрозділи Національної поліції України розпочали досудові розслідування в 77 кримінальних провадженнях за злочинами проти професійної діяльності журналістів. 3 них 58 - відкрито за ст. 171 КК України («Перешкоджання законній професійній діяльності журналістів»), 14 - за ст. 345-1 («Погроза або насильство щодо жур- 
наліста»), 4 - за ст. 347-1 («Умисне знищення або пошкодження майна журналіста «) та 1 - за ст. 348-1 («Посягання на життя журналіста»)» [1, с. 9]. Численні порушення профресійних прав журналістів фріксують і медійні організації, зокрема, за даними Національної спілки журналістів України, у 2018 році «зафріксовано 86 випадків фрізичної агресії щодо працівників 3MI, ще 89 інцидентів - у 2017 році» [1, с. 9].

Тож актуальність теми наукової роботи обґрунтовується потребами поширення знань щодо правового захисту професійних прав працівників медіа, розуміння проблеми порушення прав журналістів та детального вивчення механізмів їхнього захисту.

Аналіз останніх досліджень і публікацій. Нормативну основу дослідження становлять Кримінальний, Кримінальний процесуальний кодекси України, а також закони [2-12]. Теоретичною основою дослідження стали праці українських і зарубіжних учених із кримінального права, кримінології, цивільного, кримінального процесуального права [1; 13-18].

Мета статті полягає у розв'язанні таких проблем, як захист журналістських джерел відповідно до законодавства України, законні права журналістів і їх реалізація, а також гарантії діяльності преси, що сприятиме зміцненню чинного законодавства щодо захисту професійної діяльності працівників 3MІ та забезпечення свободи інфрормації.

Виклад основного матеріалу. Допиту журналіста як свідка передує попередження про кримінальну відповідальність за відмову від надання показань та/ або про надання завідомо неправдивих свідчень. Однак, згідно з п. 6 ч. 2 ст. 65 КПК України НЕ можуть бути допитані як свідки журналісти про відомості, які містять конфіденційну інфрормацію профеесійного характеру, надану за умови нерозголошення авторства або джерела інформації [3]. У цій нормі треба вказати, що не можуть бути допитані як свідки саме журналісти друкованого засобу масової інформації, теле-, радіожурналісти, журналісти інформаційних агентств.

Збереження конфріденційності джерела інформації, імені особи, яка надала журналісту інформацію, - основна із засад журналістської етики, що $є$ не лише правом, але й обов'язком журналіста. Згідно з Рекомендацією Комітету Міністрів Ради Європи № R (2000) 7 від 8 березня 2000 р. «Про право журналістів не розкривати свої джерела інфооммації» термін «джерело» означає будь-яку особу, яка забезпечує інфор- мацією журналістів. Крім того, тут визначено також термін «інформація, яка визначає джерело», яка охоплює «ім'я та персональні дані, такі як голос чи зображення джерела; фрактичні обставини набуття журналістом інформації від джерела; неопублікований зміст інфоомації, наданий джерелом журналісту, та персональні дані журналістів і їхніх службовців, пов'язані з їхньою профессійною діяльністю» [5].

Свідоцький імунітет дає змогу представникам медіа не давати показання, які можуть викрити їхні журналістські джерела, адже за відмову від надання вказаної інформації журналіста не можна притягнути до кримінальної відповідальності.

Проте щодо питань, які не стосуються їхньої професійної діяльності, журналіста можна допитувати без застережень. Оскільки тут не йдеться про здійснення профресійної діяльності, він мусить давати показання, а за відмову нестиме кримінальну відповідальність.

Норми професійної етики зобов'язують журналіста поважати гідність людини, ії право на приватне життя. Працівник ЗMІ має зберігати в таємниці відомості про особу, яка передала інформацію або інші матеріали, не розголошувати її імені. Журналісти мають отримувати конфіденційну інформацію лише з дозволу осіб, яким належить така інформація. Забороненим $є$ поширення відомостей, що становлять державну таємницю, або іншої інформації, яка захищена законом.

Профресійна діяльність журналіста не може бути підставою для його арешту чи затримання. Вилучення зібраних матеріалів і технічних засобів, які він використовує у своїй роботі, є незаконним.

Тимчасовий доступ до речей і документів $€$ заходом забезпечення кримінального провадження, що полягає в наданні стороні кримінального провадження особою, у володінні якої перебувають такі речі чи документи, можливості ознайомитися з ними, зробити їхні копії та вилучити їх. Тимчасовий доступ до електронних інформаційних систем або їхніх частин, мобільних терміналів систем зв'язку здійснюють через зняття копії інформації, що міститься в таких електронних інформаційних системах, мобільних терміналах, без їх вилучення, що вказано у ст. 159 КПК України [3].

Відповідно до ст. 162 КПК України охоронюваною законом таємницею, що міститься в речах і документах, є, зокрема, інформація, що перебуває у володінні засобів масової інфрормації або 
журналістів, надана їм за умови нерозголошення авторства чи джерела інформації [3]. Журналіст має право на збереження таємниці авторства та джерел інформації, за винятком випадків оприлюднення таємниць на вимогу суду.

Проведення обшуку, переважно раптового, в помешканні, де проживає чи працює журналіст, становить найбільшу небезпеку для розкриття джерел. Під час його проведення слідчі можуть отримати доступ до інформації, яка допомагає ідентифікувати журналістські джерела.

Законодавство України, на жаль, не гарантує збереження таємниці журналістських джерел під час ухвалення рішень про тимчасовий доступ до речей і документів, а також під час обшуків у приміщеннях, де журналісти працюють чи проживають. Тому потрібно вживати всіх можливих заходів, щоб унеможливити доступ сторонніх осіб до такої інформації.

Зокрема, відповідно до ст. 236 КПК України слідчі мають право проводити обшук хоч і на підставі рішення суду, проте без попередження журналістів і 3MI, і під час його проведення відкривати закриті приміщення, сховища, обшукувати осіб, які перебувають у приміщенні, вилучати документи, тимчасово вилучати речі, які мають значення для кримінального провадження [2]. Це надає доступ до необмеженого кола документів, зокрема й тих, що містять відомості про журналістські джерела. Крім того, це часто є причиною тривалої зупинки або припинення діяльності ЗМІ та значних фінансових збитків. Європейський суд із прав людини здебільшого вважає обшуки, спрямовані на розкриття журналістських «джерел», порушенням ст. 10 Конвенції про захист прав людини й основоположних свобод [4].

Водночас для розв'язання питання про тимчасовий доступ до речей і документів працівників медіа, КПК України (п. 1 ч. 1 ст. 162) зобов'язує суд враховувати те, що інформація, якою володіють засоби масової інформації або журналісти й надана їм за умови нерозголошення авторства або джерела інформації, є охоронюваною законом таємницею [3]. Аналогічні твердження КПК України (п. 7 ч. 1 ст. 162) стосуються відомостей, які $€$ в операторів і провайдерів телекомунікацій і свідчать про зв'язок абонента, надання й отримання телекомунікаційних послуг, визначення їхньої тривалості, змісту, маршруту передавання [3].

Процедура розгляду клопотання про тимчасовий доступ до речей і документів, які містять таємницю журналістських джерел і телефон- них комунікацій, має визначені правила, зазначені в ч. 6 ст. 163 КПК України: слідчий мусить довести «можливість використання як доказів відомостей, що містяться в цих речах і документах, та неможливість іншими способами довести обставини, які передбачається довести за допомогою цих речей і документів» [3].

Розглядаючи клопотання слідчого про тимчасовий доступ до речей і документів, наданих журналістові чи $3 \mathrm{MI}$ за умови нерозголошення авторства та джерела інформації, суд має пересвідчитись у тому, що інформація, наявна в цих речах і документах, може бути використана як докази, а також у тому, що встановити обставини справи іншим способом неможливо. Суд також має оцінити й інші обставини, визначені законом, перш ніж ухвалити рішення. Важливим також є те, що у разі невиконання ухвали суду про тимчасовий доступ до речей і документів суд може дати дозвіл на обшук.

Сьогодні в Україні сформовано правову базу (ст. 275 КПК України [3], п. 14 ст. 8, ст. 13, 14 Закону України «Про оперативно-розшукову діяльність» [10]), що забезпечує конфіденційне співробітництво на належному рівні, проте сучасні нормативно-правові акти потребують удосконалення відповідно до вимог розвитку українського суспільства.

У ч. 2 ст. 275 КПК та в ч. 4 ст. 11 Закону України «Про оперативно-розшукову діяльність» заборонено залучати адвокатів, нотаріусів, медичних працівників, священнослужителів, журналістів до конфіденційного співробітництва під час проведення негласних слідчих дій, якщо таке співробітництво буде пов'язано з розкриттям конфіденційної інформації професійного характеру. Згідно зі ст. 87 КПК, недотримання такої заборони під час проведення негласних слідчих дій може бути причиною визнання отриманої інформації недопустимою в доказуванні [3].

Відповідно до п. 19, 26 ч. 1 ст. 3 КПК, відкритий судовий розгляд підвищує виховну роль судового провадження, особливо для осіб, присутніх у залі судового засідання, спонукає суддів, сторони та учасників кримінального провадження діяти і висловлюватись у межах процесуального закону, додержуватись етичних вимог. Якщо судовий розгляд відбувається відкрито, у залі судового засідання мають право перебувати сторони та інші учасники судового провадження [3], а також будь-які інші особи (зокрема, представники засобів масової інформації, студенти, помічники адвоката). Якщо судовий розгляд відбувається в закритому судо- 
вому засіданні, суд виносить про це вмотивовану ухвалу й у такому випадку в залі судового засідання можуть бути присутні лише сторони та інші учасники кримінального провадження (ч. 4 ст. 27, п. 2 ч. 2 ст. 315, ч. 1 ст. 316 КПК) [3].

Незалежно від того, буде судовий розгляд відбуватись у відкритому чи закритому судовому засіданні, кількість присутніх у залі судового засідання може бути обмежена головуючим 3 причини недостатності місць у залі судового засідання. При цьому п. 1 ч. 1 ст. 3, ч. 2 ст. 328 КПК визначає коло осіб, які мають переважне право бути присутніми під час судового засідання: близькі родичі та члени сім'ї обвинуваченого й потерпілого, а також представники засобів масової інформації [3].

У разі незабезпечення відкритості судового розгляду порушується принцип гласності і відкритості судового провадження й повного фріксування технічними засобами судового засідання та процесуальних дій. Принцип гласності передбачає, що розгляд у цивільних судах $є$ відкритим: на слухання справи в залі судового засідання мають вільний доступ не тільки особи, що беруть участь у слуханні, але й усі, хто має бажання бути присутнім. Для висвітлення перебігу процесу та його результатів у залі можуть бути присутніми працівники засобів масової інфрормації. Це в особливий спосіб підвищує відповідальність суду за законне розв'язання справ, сприяє уникненню суб'єктивізму суддів і дає можливість усім охочим переконатися в дотриманні правових процедур розгляду справи.

Розглядати справу на закритому судовому засіданні можна за вмотивованим рішенням суду у випадках, передбачених процесуальним законом і ст. 27 КПК, де зазначено, що кримінальне провадження в судах усіх інстанцій здійснюється відкрито. Слідчий суддя, суд може ухвалити рішення про здійснення кримінального провадження в закритому судовому засіданні лише у встановлених цією статтею випадках. Згідно зі ст. 27 КПК кожен присутній у залі судового засідання «може вести стенограму, робити нотатки, використовувати портативні аудіозаписувальні пристрої» [2]. Фотозйомка, відеозапис, транслювання судового засідання по радіо і телебаченню, звукозапису із застосуванням стаціонарної апаратури «допускаються на підставі ухвали суду, що приймається з урахуванням думки сторін і можливості проведення таких дій без шкоди для судового розгляду» [2].
Принцип гласності і відкритості судового провадження передбачає три форми отримання інформації зі зали суду: сприйняття інформації безпосередньо в залі суду і право фріксувати iï різними засобами; отримання інформації про судовий процес через $3 \mathrm{Ml}$; ознайомлення завдяки офріційному реєстру судових рішень в інтернеті (згідно із Законом України «Про доступ до судових рішень»).

Важливість гласності як засади судочинства зумовлена необхідністю неупередженого та всебічного дослідження обставин кримінального правопорушення й ухвалення законного, обґрунтованого та справедливого рішення.

Висновки і пропозиції. Небезпеку розкриття джерела інформації працівника 3MI мають такі слідчі дії або заходи забезпечення кримінального провадження, як допит, тимчасовий доступ до речей і документів, обшук у приміщенні, де проживає чи працює журналіст.

Така гарантія, як свідоцький імунітет журналіста, дає їм змогу не давати показання, які можуть викрити їхні журналістські джерела. У разі відмови від надання зазначеної інформації журналіста не можна притягнути до кримінальної відповідальності. Однак щодо тих питань, які не стосуються його професійної діяльності, журналіста можна допитувати без застережень. У цьому випадку не йдеться про здійснення професійної діяльності, тому він мусить давати показання, а за відмову нестиме кримінальну відповідальність.

Тимчасовий доступ до речей і документів полягає у наданні стороні кримінального провадження особою, у володінні якої $є$ такі речі та документи, можливості ознайомитися з ними, зробити їхні копії чи вилучити їх. Проте охоронюваною законом таємницею, що міститься в речах і документах, є, зокрема, інформація, що перебуває у володінні засобів масової інформації або журналістів, надана їм за умови нерозголошення авторства чи джерела інформації. Тому журналіст має право на збереження таємниці авторства та джерел інфрормації, за винятком випадків, коли ці таємниці оприлюднюються на вимогу суду.

Гласність судового провадження та повне фріксування технічними засобами судового засідання і процесуальних дій $€$, відповідно до ст. 129 Конституції України, однією з головних засад судочинства. Крім того, Міжнародним пактом про громадянські і політичні права та Конвенцією про захист прав людини й основоположних свобод, які $є$ частиною національ- 
ного законодавства, проголошено, що кожен, кому пред'явлено обвинувачення у вчиненні кримінального правопорушення, має право на справедливий, публічний розгляд його справи в незалежному суді.

Проблеми, пов'язані із захистом преси в Україні, потребують подальших наукових досліджень відповідно до нового кримінального процесуального законодавства. Сьогодні особливо актуальним є доопрацювання та розроблення нормативних документів і методичних рекомендацій щодо захисту представників засобів масової інформації.

\section{Список використаної літератури:}

1. Опришко Л.В., Вдовенко О.М. Проблеми розслідування та судового розгляду кримінальних справ, пов'язаних із порушенням професійних прав журналістів в Україні: аналітичний звіт. Київ : ГО «Платформа прав людини», 2019.66 с.

2. Кримінальний кодекс України. Відомості Верховної Ради України. 2001. № 25. Ст. 131.

3. Кримінальний процесуальний кодекс України. Відомості Верховної Ради України. 2013. № 9-10, № 11-12, № 13. Ст. 88.

4. Конвенція про захист прав людини і основоположних свобод від 4 листопада 1950 р. Офріційний вісник України. 2006. № 32. Ст. 270.

5. Рекомендація Комітету Міністрів Ради Європи № R (2000) 7 від 8 березня 2000 р. «Про право журналістів не розкривати свої джерела інфрормації». URL: https://cedem.org.ua/library/ rekomendatsiya-r-2000-7-pro-pravo-zhurnalistivne-rozkryvaty-svoyi-dzherela-informatsiyi/ (дата звернення: 12.08.2020).

6. Про друковані засоби масової інформації (пресу) в Україні : Закон України від 16 листопада 1992 р. Відомості Верховної Ради України. 1993. № 1. Ст. 1.

7. Про державну підтримку засобів масової інформації та соціальний захист журналістів : Закон України від 23 вересня 1997 р. № 540/97. Відомості Верховної Ради України. 1997. № 50. Ст. 302.
8. Про інформаційні агентства : Закон України від 28 лютого 1995 р. № 74/95. Відомості Верховної Ради України. 1995. № 13. Ст. 83.

9. Про інформацію : Закон України від 2 жовтня 1992 р. № 2657-XII. Відомості Верховної Ради України. 1992. № 48. Ст. 650.

10.Про оперативно-розшукову діяльність : Закон України від 18 лютого 1992 р. № 2136-XII. Відомості Верховної Ради України. 1992. № 22. Ст. 303.

11. Про телебачення і радіомовлення : Закон України від 21 грудня 1993 р. Відомості Верховної Ради України. 1994. № 10. Ст. 43.

12.Про телекомунікації : Закон України від 18 листопада 2003 р. № 1280-IV. Відомості Верховної Ради України. 2004. № 12. Ст. 155.

13.Гольдберг Н. Проблеми регулювання конфіденційного співробітництва при здійсненні негласних слідчих (розшукових) дій. Национальный юридический журнал: теория и практика. 2016. № 1-2. С. 100-103.

14.Доманська В.О., Тимошенко П.Ю. Свідоцький імунітет у контексті співвідношення правових норм, що регулюють кримінально-процесуальні та шлюбно-сімейні відносини. Науковий вісник Київького національного університету внутрішніх справ. 2007. № 5. С. 78-84.

15.Кримінальний процесуальний кодекс України: науково-практичний коментар / відп. ред. С.В. Ківалов, С.М. Міщенко, В.Ю. Захарченко. Харків : Одіссей, 2013. 1104 с.

16.Науково-практичний коментар до Кримінального процесуального кодексу України від 13 квітня 2012 року / за ред. О.А. Банчука, Р.О. Куйбіди, М.І. Хавронюка. Харків : Фактор, 2013. 1072 c.

17.Опришко Л.В., Вдовенко О.М. Рекомендації щодо захисту прав журналістів, які стали жертвою агресії у зв'язку з виконанням професійних обов'язків в Україні: практичний посібник. Київ : ГО «Платформа прав людини», 2019. 72 с.

18.Удалова Л.Д. Свідоцький імунітет за новим КПК України. Юридичний часопис Національної академії внутрішніх справ. 2013. № 1. C. 284-288.

\section{Bulyk-Verkhola S. Z., Verkhola A. O. The features of criminal procedural protection of the press in Ukraine}

The article analyzes the features of criminal procedural protection of the press in Ukraine: clarifies the mechanisms of protection of journalistic sources, such as "witness immunity of a journalist" and "temporary access to things and documents and search of the premises where the journalist lives and / or works"; the issue of involving journalists in confidential cooperation is described; the principle of publicity and openness of court proceedings and full recording by technical means of court hearings and procedural actions is considered, namely regarding the preemptive right of journalists to be in the courtroom.

The journalist's witness immunity allows them not to testify that could expose their journalistic sources. In case of refusal to provide this information, the journalist cannot be prosecuted. However, on issues that do not relate to his professional activities, the journalist may be questioned without 
reservation. In this case, it is not a matter of professional activity, so he must testify, and for refusal will be criminally liable.

Temporary access to things and documents is to provide the party of the criminal proceedings with a person in possession of such things and documents, the opportunity to inspect them, make copies or seize them. However, the legally protected secret contained in things and documents is, in particular, information in the possession of the media or journalists, provided to them on condition of non-disclosure of authorship or source of information. Therefore, a journalist has the right to maintain the secrecy of authorship and sources of information, except in cases where these secrets are disclosed at the request of the court.

One of the main principles of judicial proceedings, defined by Article 129 of the Constitution of Ukraine, is the publicity of court proceedings and full recording by technical means of court hearings and procedural actions. In addition, the International Covenant on Civil and Political Rights and the Convention for the Protection of Human Rights and Fundamental Freedoms, which are part of national law, declare that everyone charged with a criminal offense has the right to a fair, public hearing by an independent and impartial court.

Key words: journalists' rights, protection of journalistic sources, witness immunity of journalists, confidential cooperation, freedom of information, principle of publicity and openness of court proceedings and full recording by technical means of court hearings and procedural actions. 


\title{
УДК 347.1
}

DOI https://doi.org/10.32840/1813-338X-2020.3.23

\author{
М. Д. Денисовський
}

кандидат юридичних наук, декан юридичного відділення Галицького коледжу імені В'ячеслава Чорновола

\section{O. Томчук}

кандидат юридичних наук, завідувач кафедри права

Галицького коледжу імені В'ячеслава Чорновола

\section{Л. В. Петруник}

здобувач вищої освіти юридичного відділення Галицького коледжу імені В'ячеслава Чорновола

\section{ПРОЦЕСУАЛЬНІ АСПЕКТИ ПРОВЕДЕННЯ ОБШУКУ ЯК ОДНОГО ІЗ ЗАСОБІВ ОТРИМАННЯ ДОКАЗІВ У КРИМІНАЛЬНОМУ ПРОВАДЖЕННІ}

Статтю присвячено дослідженню актуальних для сучасної правозастосовної практики питань, пов'язаних із проведенням обшуку під час кримінального провадження. Зокрема, порушуються найбільш поширені проблеми процесуального порядку проведення обшуку, які полягають у допущенні уповноваженими особами помилок і зловживань через неправильне розуміння, застосування та недотримання регламентованої Кримінальним процесуальним кодексом України процедури обшуку, що підтверджується сталою судовою практикою. Висвітлено детальне роз'яснення та певні недоліки правових норм кримінального процесуального законодавства, а також запропоновано способи оптимізації положень чинного законодавства щодо забезпечення ефективності застосування обшуку як одного із засобів отримання доказів у кримінальному провадженні.

Доведено, що в кожному конкретному випадку обов'язково потрібно встановити наявність усіх необхідних для належного проведення обшуку юридичних і фрактичних підстав. Зокрема, потреба в повному та обгрунтованому аргументуванні останніх у змісті клопотання про надання дозволу на обшук, що нині не завжди виконується працівниками правоохоронних органів, і призводить до маневру під час обшуку.

Зроблено висновок про те, що клопотання про проведення обшуку у кримінальному провадженні щодо корупиійного злочину обов'язково подається у Вищий антикорупційний суд, а не у місцевий. Констатовано, що розгляд клопотання про надання дозволу на проведення обшуку має проводитися за участю слідчого, прокурора, а також в обов'язковому порядку супроводжуватись повною технічною фріксацією засідання. Право безпосереднього проведення обшуку мають лише особи передбачені в ухвалі слідчого судді, при цьому неможливо залучати співробітників оперативних підрозділів до проведення цієї процесуальної дії. В разі порушення вищезазначених положень усі докази, які було отримано під час обшуку, вважаються недопустимими.

Авторами статті визначено доцільність поширення обов'язкового фріксування порядку проведення обшуку за допомогою аудіо- та відеозапису у разі проведення обшуку без ухвали слідчого судді в порядку, передбаченомуч. $3 \mathrm{~cm}$. 233 Кримінального процесуального кодексу України.

Ключові слова: кримінально-процесуальні відносини, розслідування злочину, слідчі (розшукові) дії, житло та інше володіння особи, уповноважені особи. 
Постановка проблеми. Одним з основних завдань сучасної правової держави $€$ не лише гарантування, а й здійснення належного та реального захисту прав, свобод і законних інтересів людини й громадянина в будь-якій правовій ссрері, зокрема у кримінальному судочинстві. Тому задля досягнення визначеної мети активно проводиться реформування кримінальної юстиції, що зумовлює виникнення максимальної наближеності кримінального процесу України до міжнародних стандартів охорони та захисту прав, свобод ізаконнихінтересівосіб-учасників кримінальнопроцесуальних відносин.

Обумовивши в положеннях ст. 2 Кримінального процесуального кодексу України (далі КПК України) таку охорону одним з основних завдань кримінального провадження, кримінальне процесуальне законодавство передбачає можливість, а в окремих випадках і необхідність, проведення певних процесуальних дій, від своєчасності та обґрунтованості яких багато в чому залежить ефективність як досудового розслідування, так і судового розгляду відповідної кримінальної справи. Наприклад, відповідно до ст. 62 Конституції України особа $€$ невинуватою у вчиненні кримінального правопорушення, поки її вину не буде доведено в законному порядку і встановлено обвинувальним вироком суду [1]. У правових приписах КПК України передбачено безліч способів збирання доказів, але, на нашу думку, найвагоміше місце серед них відіграє саме обшук. Ця слідча (розшукова) дія, з одного боку, є найбільш ефективною та затребуваною у практиці, оскільки спрямована на отримання насамперед речових доказів, проте з іншого - вагомо обмежує конституційні права та свободи учасників кримінального провадження, адже згідно з положеннями ст. 8 Конвенції про захист прав людини й основних свобод «кожен має право на повагу до його приватного і сімейного життя, до житла та таємниці кореспонденції» [2].

Керуючись даними судової звітності за 20182019 рр., можна стверджувати, що кількість поданих клопотань про надання дозволу на обшук житла чи іншого володіння особи до судів першої інстанції все ж таки зменшилась. Наприклад, за 2018 рік надійшло 96122 клопотання, з яких 72764 - задоволено, 15605 - відмовлено, натомість за 2019 рік надійшло 95441 клопотання, з яких 69712 - задоволено, а в задоволенні 15279 клопотань було відмовлено [3]. Проте наведені числа демонструють нам існу- вання не лише професійного, належного ставлення слідчих, прокурорів і слідчих суддів до проведення такої процесуальної дії, але й необґрунтованого та безпідставного звернення органів досудового розслідування з відповідними клопотаннями, що підтверджується також вагомою кількістю задоволених скарг на дії та бездіяльність слідчого, прокурора в порядку ч. 3 ст. 233 КПК України.

Ми вважаємо, що така ситуація є безпосередньо наслідком допущених уповноваженими особами помилок і зловживань через неправильне розуміння, застосування та недотримання регламентованого КПК України порядку проведення обшуку. Тому існування таких проблемних питань як правового, так і організаційного характеру потребує негайного розв'язання.

Аналіз останніх досліджень і публікацій. На різних етапах розвитку кримінального процесуального права обшук завжди був предметом багатьох досліджень, дискусій і розглядався вченими-процесуалістами та криміналістами в найрізноманітніших аспектах. Наприклад, відповідні думки та пропозиції щодо правової природи, підстав і порядку проведення обшуку містяться у працях В.К. Весельського, В.І. Галагана, В.Я. Горбачевського, Ю.М. Грошевого, А.В. Іщенка, О.В. Капліної, В.С. Кузьмічова, О.П. Кучинської, О.І. Литвинчука Л.М. Лобойка, Є.Д. Лук'янчикова, М.С. Сороки, та ін. Та всетаки сьогодні $\epsilon$ потреба в подальшому дослідженні цієї слідчої (розшукової) дії з врахуванням сорормованих сучасних тенденцій щодо правової природи та поняття обшуку, підстав, об'єктів і порядку його проведення, міжнародно-правових стандартів і зарубіжного досвіду.

Метою статті $\epsilon$ висвітлення теоретичних і практичних положень процедури проведення обшуку у кримінальному провадженні, фрормулювання науково обґрунтованих пропозицій і рекомендацій з удосконалення кримінального процесуального законодавства.

Виклад основного матеріалу. Обшук як один із видів слідчих (розшукових) дій регламентується ст. ст. 234-236 КПК України, але, на жаль, їхній зміст досить часто породжує у слідчих і прокурорів безліч запитань. Насамперед варто зазначити, що КПК України в жодній зі своїх статей не визначає поняття обшуку. У ч. 1 ст. 234 КПК України лише передбачено мету цієї слідчої розшукової дії, а саме: «виявлення та фріксація відомостей про обставини вчинення кримінального правопорушення, відшукання знаряддя кримінального правопору- 
шення або майна, яке було здобуте у результаті його вчинення, встановлення місцеперебування розшукуваних осіб» [4].

Проте з наукового погляду обшук $є$ слідчою (розшуковою) дією, сенсом якої виступає примусове обстеження приміщень, споруд, ділянок місцевості або окремих громадян із метою знаходження й вилучення речей і документів, що мають значення для кримінального провадження, виявлення розшукуваних осіб, трупів, тварин, речей і предметів, вилучених законом з обігу, а також пошук грошей і майна для забезпечення відшкодування заподіяних збитків і з метою можливої конфріскації.

Серед безліч думок науковців-криміналістів, на нашу думку, заслуговує уваги підхід О.В. Капліної, яка виділяє два види обшуку, а саме: обшук, що являє собою процесуальне примусове обстеження житла чи іншого володіння особи, а також обшук окремих осіб задля відшукання та вилучення речових доказів і документів, що підлягають доказуванню у кримінальному провадженні, виявлення розшукуваної особи або ж майна, яке забезпечує відшкодування збитків чи $є$ забороненим до обігу [5].

У цьому контексті під поняттям «житло особи», згідно з ч. 2 ст. 233 КПК України, варто розуміти будь-яке приміщення та його складові частини, які перебувають у постійному чи тимчасовому володінні особи, незалежно від їхнього призначення і правового статусу, що пристосовані для постійного або тимчасового проживання фрізичних осіб, крім приміщень, спеціально призначених для утримання осіб, права яких обмежені за законом. При цьому керуючись п. 1 ст. 8 Конвенції про захист прав людини й основоположних свобод, можливо стверджувати, що це поняття поширюється також і на офрісні приміщення, що належать як фрізичним, так і юридичним особам, їхнім фріліям. Під іншим володінням особи розуміються транспортний засіб, земельна ділянка, гараж, інші будівлі чи приміщення побутового, службового, господарського та іншого призначення тощо, що перебувають у законному володінні особи [2].

Оскільки обшук $є$ процесуальною дією, що значно обмежує конституційне право особи на недоторканність житла чи іншого володіння, та, безперечно, втручається в особисте життя громадянина, то він може проводитись лише за наявності юридичних і фактичних підстав, що передбачені в КПК України. Під юридичними підставами варто розуміти насамперед наявність розпочатого кримінального провадження, відомості щодо якого внесено в Єдиний реєстр досудових розслідувань (далі - ЄРДР), а також постановлену слідчим суддею ухвалу про надання дозволу на обшук житла чи іншого володіння особи. У разі її відсутності проведення обшуку тягне за собою кримінальну відповідальність, передбачену ст. 162 (порушення недоторканності житла) Кримінального кодексу України. Проте законодавство передбачає, що обшук особи може бути проведено й без ухвали слідчого судді, лише за рішенням слідчого чи прокурора, у разі наявності достатніх підстав уважати, що особи, які перебувають у цьому житлі чи іншому володінні, переховують на собі предмети або документи, які мають значення для кримінального провадження, або ж під час затримання особи, яка підозрюється у вчиненні злочину, якщо є достатні підстави вважати, що затриманий має при собі зброю або інші предмети, які несуть загрозу для навколишніх, чи намагається звільнитися від доказів, що викривають його чи інших осіб у вчиненні злочину.

Фактичними підставами проведення обшуку $€$ наявність здобутих достовірних даних, які дають змогу стверджувати про те, що справді було скоєно злочин, відшукуванні речі мають значення для розслідування цього незаконного діяння й однозначно розташовані в місті, передбаченому у клопотанні, обшук $є$ найбільш доцільним та ефективним у цьому випадку способом отримання доказів. Саме ці та інші відомості має бути зазначено й належним чином доведено у змісті клопотання про дозвіл на обшук [6, с. 10].

Задля того, щоб провести обшук, слідчий за погодженням із прокурором або прокурор звертається до слідчого судді з відповідним клопотанням, в якому відображаються відомості, передбачені ч. 3 ст. 234 КПК України, а саме:

1) найменування кримінального провадження та його реєстраційний номер;

2) короткий виклад обставин кримінального правопорушення, у зв'язку з розслідуванням якого подається клопотання;

3) правова кваліфрікація кримінального правопорушення із зазначенням статті (частини статті) закону України про кримінальну відповідальність;

4) підстави для обшуку;

5) житло чи інше володіння особи або частина житла чи іншого володіння особи, де планується проведення обшуку;

6) особа, якій належить житло чи інше володіння, та особа, у фрактичному володінні якої воно перебуває; 
7) індивідуальні або родові ознаки речей, документів, іншого майна або осіб, яких планується відшукати, а також їхній зв'язок із вчиненим кримінального правопорушення;

8) обґрунтування того, що доступ до речей, документів або відомостей, які можуть у них міститися, неможливо отримати органом досудового розслідування в добровільному порядку шляхом витребування речей, документів, відомостей, відповідно до ч. 2 ст. 93 КПК України, або за допомогою інших слідчих дій, передбачених КПК України, а доступ до осіб, яких планується відшукати, - за допомогою інших слідчих дій, передбачених КПК України.

На нашу думку, уповноважена особа під час готування клопотання має відповідально поставитися до вимоги про зазначення обставин вчиненого кримінального правопорушення і не відображати у ньому всі фракти кримінальної події. Оскільки досить часто відомості із клопотання аналогічно переносяться в зміст ухвали слідчого судді, яка може потрапити до рук будьякого учасника кримінального провадження. Така неуважність може призвести до розголошення таємниці досудового розслідування великому колу осіб, чим порушити конституційні права та свободи особи. Також, як свідчить стала практика, слідчі та прокурори, звертаючись до слідчого судді з цими клопотаннями, не зазначають у їхньому змісті індивідуальні або родові ознаки речей, документів, іншого майна або осіб, яких планується відшукати, чим автоматично собі відкривають великий простір для маневру під час обшуку. Відсутність у клопотаннях такого посилання однозначно призводить до порушення недоторканності житла, що гарантоване КПК України, Конституцією України та неповною мірою відповідає п. 7 ч. 3 ст. 234 та п. 6 ч. 2 ст. 235 КПК України. Тому уповноваженим особам у разі неможливості точного зазначення індивідуальних ознак речей, які підлягають відшукуванню, у клопотанні потрібно передбачати родові ознаки задля недопущення надалі суперечностей.

Крім того, слідчому та прокуророві потрібно належним чином перевіряти зміст складеного проєкту документа на його законність, обґрунтованість і вмотивованість. Оскільки ні повернення такого клопотання на усунення недоліків, ні повторний його розгляд слідчим суддею КПК України не допускається, крім випадків виявлення нових обставин, що не розглядалися слідчим суддею попередньо. Варто згадати, що до клопотання в обов'язковому порядку дода-
єТься витяг з ЄРДР щодо кримінального провадження, у межах якого воно подається, а також оригінали або копії документів та інших матеріалів, якими прокурор, слідчий обґрунтовує доводи клопотання. Цей документ виготовляється на бланку органу досудового розслідування та підписується слідчим, який його склав, а також прокурором, який погодив зазначене клопотання, із зазначенням дати погодження. Складається в трьох примірниках: один надається до суду, у межах територіальної юрисдикції якого перебуває орган досудового розслідування, а інші - долучаються до матеріалів кримінального провадження та наглядового провадження прокурора.

Проте варто зазначити, що клопотання про дозвіл на проведення обшуку у кримінальному провадженні щодо корупційних злочинів, якщо наявна хоча б одна з умов, передбачених пп. 1-3 ч. 5 ст. 216 КПК України, обов'язково подається не у місцевий суд, а у Вищий антикорупційний суд. Досить часто правоохоронці вважають, що Вищий антикорупційний суд створений тільки для звернення до нього детективів Національного антикорупційного бюро та прокурорів Спеціалізованої антикорупційної прокуратури, що призводить до неправомірних дій з їхнього боку.

Згідно з ч. 4 ст. 234 КПК України клопотання про надання дозволу на обшук розглядається слідчим суддею обов'язково в день його надходження за участю слідчого або прокурора. Неявка останніх позбавляє слідчого суддю змоги повно та всебічно з'ясувати необхідність проведення цієї слідчої (розшукової) дії, тому, як правило, в таких випадках відмовляють у задоволенні клопотання про обшук. Наступним важливим моментом $\epsilon$ те, що розгляд клопотання про надання дозволу на проведення обшуку має в обов'язковому порядку супроводжуватись повною технічною фіксацією засідання. Якщо цього не було виконано, згідно з п. 4 ч. 3 ст. 87 КПК України, всі отримані під час виконання ухвали про дозвіл на обшук докази $€$ недопустимими. Проте, незважаючи на вищезазначені вимоги законодавства, у практиці $\epsilon$ поодинокі випадки порушення вищезазначених правових норм, що має бути використано стороною захисту для доведення факту незаконного проведення слідчої (розшукової) дії.

У разі задоволення клопотання слідчим суддею постановляється відповідна ухвала про дозвіл на обшук, дві копії якої передають слідчому для безпосереднього проведення дії. 
Варто пам'ятати, що в цьому документі чітко передбачено тих слідчих, які мають право проводити обшук. У такому разі доручати його проведення працівникам оперативного підрозділу або детективам, які не зазначені в ухвалі, забороняється. Якщо в ухвалі дозвіл на проведення обшуку надано «групі слідчих», «групі прокурорів», «слідчо-оперативній групі» тощо, адвокатові треба вказати це як зауваження в протоколі обшуку з метою подальшого доведення недопустимості отриманих у результаті обшуку доказів. Також вагомим фрактом неправильного розуміння закону є і те, що дуже часто під час проведення обшуку слідчі все-таки залучають до цього працівників оперативних підрозділів. Ці дії суперечать правовим нормам, передбаченим ст. 236 та п. 26 ст. 3 КПК України, згідно з якими співробітники оперативних підрозділів не належать до учасників кримінального провадження, а отже не мають права брати участь у проведенні цієї процесуальної дії. Крім того, застосування в цьому випадку положень п. 3 ст. 40 КПК України також $є$ недоцільним, оскільки передбачає доручення проведення окремих слідчих (розшукових) дій, а не залучення співробітників оперативних підрозділів до таких дій. Отже, залучення оперативного працівника до проведення обшуку та виявлення таким працівником речового доказу чи документа надалі призводитиме до визнання таких доказів судом недопустимими.

Згідно з ч. 3, 7 ст. 223, 236 КПК України під час проведення обшуку, обов'язково мають бути присутніми поняття в будь-якій кількості, але не менш ніж дві особи. Проте варто пам'ятати, що ними не можуть бути потерпілий, родичі підозрюваного чи потерпілого, працівники правоохоронних органів, а також особи, зацікавлені у результатах кримінального провадження. Через це потрібно шукати зовсім сторонніх осіб, які б погодились бути присутніми під час такої досить тривалої і напруженої слідчої (розшукової) дії. Це однозначно створює проблему для слідчого, яка у практиці розв'язується досить просто і швидко - шляхом залучення одних і тих самих осіб, з якими в них $€$ певні домовленості (друзі, далекі родичі чи колишні працівники правоохоронних органів). 3 цього можливо зробити висновок про існування своєрідної «зацікавленості понятих» у результатах кримінального провадження, що породжує порушення встановленого законодавством порядку проведення обшуку. Для того щоб належним чином довести цей факт у суді, доцільно насамперед ознайо- митись із протоколами обшуків цього слідчого, викликати зазначених понятих як свідків і під час судового засідання встановити наявність відносин із працівниками правоохоронного органу і кількість випадків їхнього перебування у правовому статусі понятих.

Також регламентується й обов'язкова присутність під час проведення обшуку осіб, чиї права та законні інтереси може бути обмежено або порушено (особи у володінні яких перебуває обшукуване приміщення чи інше володіння, члени їхньої сім'ї, уповноважені представники підприємства, установи, організації тощо). Зважаючи на цю вимогу закону, обшук, за винятком невідкладних випадків, необхідно проводити тоді, коли зазначені особи перебуватимуть на обшукуваних об'єктах. У разі виникнення необхідності пошуку та вилучення (копіювання) інформації та електронних інформаційних систем або їхніх частин чи мобільних терміналів систем зв'язку до обшуку обов'язково залучаються відповідні спеціалісти.

Згідно з ч. 10 ст. 236 КПК України обшук житла чи іншого володіння особи на підставі ухвали слідчого судді обов'язково має фріксуватися за допомогою аудіо- та відеозапису, проте вимоги щодо такої фіксації обшуку, проведеного без ухвали слідчого судді в чинному законодавстві, сьогодні відсутні. Вважаємо за доцільне внести ці зміни в ч. 3 ст. 233 КПК України. Оскільки аудіо- чи відеозапис проведення обшуку не може мати самостійного процесуального значення, обшук набуде правового значення лише після відповідного процесуального оформлення: у вигляді протоколу та додатків до нього. При цьому варто пам'ятати, що протокол має відповідати вимогам, які регламентовані ст. ст. 104, 105 КПК України, а також повно та об'єктивно відображати хід і результати проведеної процедури.

Висновки і пропозиції. Беручи до уваги все вищезазначене, можна стверджувати, що регламентована процесуальна форма обшуку загалом відповідає положенням Конституції України і є придатною для отримання допустимих доказів. Водночас кримінальні процесуальні норми, що визначають підстави та порядок проведення зазначеної слідчої (розшукової) дії, $€$ в деяких аспектах недосконалими. Отже, пропонуємо внести зміни до ч. 3 ст. 233 КПК України та викласти її в такій редакції: «Слідчий, дізнавач, прокурор має право до постановлення ухвали слідчого судді ввійти до житла чи іншого володіння особи лише у невідкладних випад- 
ках, пов'язаних із врятуванням життя людей та майна чи з безпосереднім переслідуванням осіб, які підозрюються у вчиненні кримінального правопорушення. У такому разі всі дії слідчого, дізнавача, прокурора в обов'язковому порядку фріксуються за допомогою аудіо- та відеозапису. Після здійснення таких дій прокурор, слідчий, дізнавач за погодженням із прокурором зобов'язаний невідкладно звернутися до слідчого судді із клопотанням про проведення обшуку...».

\section{Список використаної літератури:}

1. Конституція України від 28 червня 1996 р. № 254к/96-BP. URL: http://zakon1.rada.gov.ua/ laws/show $/ 254 \%$ D 0 \% B A/ $96 \%$ D $0 \%$ B $2 \%$ D1\%80 (дата звернення: 30.07.2020).

2. Конвенція про захист прав людини і основоположних свобод (Дата ратифрікації Україною: 17.07.1997 р. Дата набрання чинності для України:11.09.1997р.).URL:https://zakon.rada.gov.ua/ laws/show/995_004\#Text (дата звернення: 04.08.2020).
3. Узагальнення судової практики розгляду судами I інстанції клопотань про надання дозволу на проведення обшуку житла чи іншого володіння особи у 2018-2019 роках. URL: https://court.gov.ua/inshe/sudova_statystyka/ (дата звернення: 04.08.2020).

4. Кримінальний процесуальний кодекс України від 13 квітня 2012 р. № 4651-VI. URL: http://zakon 1.rada.gov.ua/laws/show/ 4651-17 (дата звернення: 05.08.2020).

5. Капліна О.В. Проблеми нормативного регулювання та практики проведення обшуку під час кримінального провадження. Часопис Національного університету «Острозька академія». Серія «Право». 2015. № 2 (12). URL: https://lj.oa.edu.ua/articles/2015/n2/15kovckp.pdf (дата звернення: 30.07.2020).

6. Литвинчук О.І., Сорока М.С., Колесников І.В. Електронні докази. Обшук. Ч. 1. Харків : Фактор, 2020. 80 c. URL: https://unba.org.ua/ assets/uploads/publications/\%D0\%9F\%D0\%94\% D0\%A4_\%20Electronni\%20Dokazy\%200bshuk\% 20Part1.pdf (дата звернення: 30.07.2020).

Denysovskyi M. D., Tomchuk I. O., Petrunyk L. V. Procedural aspects of the conducting a search as one of the means of obtaining evidence in criminal proceedings

The article deals with the study of issues relevant to modern law enforcement practice related to the search during criminal proceedings. In particular, the most common problems of the procedural procedure of conducting a search are raised. These problems refer to the commission of errors and abuses by authorized persons due to the misunderstanding, application and not following regulated search procedure according to the Criminal Procedure Code of Ukraine. A detailed explanation and certain shortcomings of the legal norms of criminal procedure legislation are highlighted, as well as the ways to optimize the current legislation to ensure the efficiency of the application a search as one of the means of obtaining evidences in criminal proceedings.

It has been proven that in each case, it is necessary to establish the existence of all necessary legal grounds and as a matter of facts grounds for a proper search. In particular, the paper examines the necessity for full and substantiated reasoning of the latter by means of the request for permission to conduct a search, which is currently not always performed by law enforcement officers and leads to maneuver during the search.

The author argues that a request for a conducting a search in a criminal procedure that refers a corruption offense must be filed into the High Anti-Corruption Court, but not into the local one. It is determined that the consideration of the request for conducting a search must be carried out with the participation of the investigator, the prosecutor with a full technical recording of the meeting. Only persons who are in the decision of the investigating judge have the right to conduct a direct search, and it is impossible to involve employees of operational units in carrying out this procedural action. In case of violation of the above provisions, all evidences obtained during the conducting a search are considered irrelevant and inadmissible.

The expediency of extending the compulsory recording of the conducting a search procedure by means of audio and video recordings to cases of the conducting a search without the decision of the judge investigator according to Part 3 of Article 233 of the Criminal Procedure Code of Ukraine is determined.

Key words: criminal procedure relations, investigation of a crime, investigatory (detective) actions, house and other property of a person, authorized persons. 
УДК 344.13

DOI https://doi.org/10.32840/1813-338X-2020.3.24

Ю. В. Шапошников

аспирант кафедры криминального права № 2 Национального юридического университета имени Ярослава Мудрого

\section{СУБЪЕКТИВНАЯ СТОРОНА НЕПОВИНОВЕНИЯ (СТ. 402 УК УКРАИНЫ)}

В статье проанализированы взәляды ученых-криминалистов относительно субъективной стороны преступления, предусмотренного ст. 402 УК Украины («Неповиновение»). Автор считает, что эта проблематика недостаточно изучена, так как в монографической литературе и в комментариях к уголовному кодексу исследователи ограничиваются только упоминанием об умысле. При этом не уточняют, какой вид умысла присущ данному составу преступления, а если и уточняют, то не аргументируют свою позицию. Разрабатывая проблему субъективной стороны неповиновения, автор проанализировал мнения различных ученых по поводу содержания интеллектуальных и волевых признаков умысла. Был сделан вывод, что при совершении неповиновения военнослужащий осознает не только общественную опасность, но и противоправность своего деяния, так как он должен знать положения воинских уставов. В тех случаях, когда в силу различных обстоятельств, не зависящих от его воли, военнослужащий не был ознакомлен с предписаниями воинских уставов, речь не может идти об осознании противоправности невыполнения приказов командира (начальника), а исходя из этого - и об общественной опасности этих действий.

При совершении неповиновения осознанием военнослужащего охватываются следующие пункты: 1) военнослужащий осознает, что он является подчиненным по званию или должности лицу, которое отдает приказ; 2) военнослужащий осознает, что приказ отдан в надлежащем порядке, в пределах полномочий командира и не противоречит действующему законодательству; 3) военнослужащий осознает свой служебный дола безоговорочно выполнять приказ командира (начальника), а также то, что он обязан доложить лицу, который отдал приказ о его выполнении.

Так как диспозиция состава неповиновения сконструирована как преступление с фрормальным составом, автором были рассмотрены три точки зрения по поводу субъективной стороны преступлений с такой конструкцией состава преступления. Сделан вывод, что точка зрения ученых, которые считают, что преступления с фоормальным составом преступления совершаются только с прямым умыслом, является наиболее обоснованной.

Ключевые слова: военнослужащий, командир, начальник, подчиненный, неповиновение.

Постановка проблемы. Анализ научной литературы позволяет сделать вывод, что вопросам, касающимся субъективной стороны неповиновения, уделялось мало внимания со стороны исследователей. Как правило, они ограничивались высказываниями, что неповиновение совершается только с прямым умыслом, а при другом умышленном невыполнении приказа возможны два вида умысла: как прямой, так и косвенный. Сделаем попытку осветить этот вопрос.

Анализ последних исследований и публикаций. Существенный вклад в разработку вопросов воинских преступлений в период независимости Украины сделали следующие ученые: Г.В. Андрусив, В.М. Билоконев,
П.П. Богуцкий, В.П. Бондаевский, В.К. Грищук, М.И. Мельник, В.А. Навроцький, Н.И. Панов, М.С. Туркот, Н.И. Хавронюк, С.А. Харитонов, Г.И. Чангули.

Цель статьи. На основании анализа научной литературы проанализировать субъективную сторону неповиновения ст. 402 УК Украины.

Изложение основного материала. Прежде чем анализировать субъективную сторону неповиновения, следует разграничить прямой и косвенный умысел по их интеллектуальным и волевым моментам. Общеизвестно, что каждый вид умышленной фрормы вины характеризуется осознанием общественной опасности своего деяния, предвидением наступления общественно опасных последствий и проявле- 
нием воли в виде желания наступления этих последствий либо их сознательного допущения.

По первому интеллектуальному признаку умысла в теории уголовного права не существует значительных разногласий, как при прямом, так и при косвенном умысле доминирует мнение о том, что субъект осознает общественную опасность своего деяния и, по мнению А.И. Рарога, это осознание охватывает фактическое содержание и социальные качества всех элементов действия или бездействия [1, с. 21]. Неоднозначными являются позиции ученых относительно осознания противоправности своих действий. В науке существует три точки зрения относительно этой проблемы: 1) вместе с осознанием общественной опасности деяния лицо должно осознавать и его противоправность; [2, с. 26-27] 2) осознание противоправности нецелесообразно включать в содержание интеллектуального момента умысла [3, с. 14]; 3) осознание общественной опасности отождествляют с осознанием противоправности $[4 ; 6]$.

По нашему мнению, в большинстве случаев совершение неповиновения не является исключением, лицо, совершающее умышленное преступление наряду с осознанием общественной опасности, осознает противоправность своего деяния. Диспозиция ст. 402 УК Украины имеет так называемую смешанную противоправность, нарушая ее предписания, военнослужащий нарушает общие обязанности военнослужащих, которые предусмотрены в ст. 11 Устава внутренней службы Вооруженных Сил Украины и ст. 6 Дисциплинарного устава Вооруженных Сил Украины. С этими двумя базовыми для воинской службы нормативными актами каждый военнослужащий должен быть ознакомлен в первую очередь. В тех случаях, когда в силу различных обстоятельств, не зависящих от его воли, военнослужащий не был ознакомлен с предписаниями воинских уставов, речь не может идти об осознании противоправности невыполнения приказов командира (начальника), а исходя из этого - и об общественной опасности этих действий. Когда речь идет о специальном субъекте преступления, исполнителем которого может быть лишь определенное лицо, как в нашем случае - военнослужащий, его умыслом должен охватываться характер нарушения специальных обязанностей, которые определяют специфические свойства самого нарушения отношений воинской службы. В случае совершения неповиновения осознание общественной опасности деяния следует из понимания ее противоправности, а не наоборот. Деяние приобретает признак противоправности только после его законодательной оценки. Законодатель не имеет права криминализировать деяния, которым не присущ признак «общественная опасность», - это нарушает логику построения уголовного закона, только общественно опасные деяния могут быть признаны противоправными. Криминализация деяния является законодательным способом закрепления в законе объективно существующей общественной опасности деяния. Именно после закрепления в соответствующей норме уголовного закона общественно опасного деяния оно приобретает два других признака: противоправность и наказуемость. Общественная опасность является базовым признаком преступления, а противоправность - производным от нее [5; 2]. Как верно отметила С.Ю. Кораблева, только в исключительных случаях противоправные деяния лишены признака общественной опасности, и эти случаи касаются государств с тоталитарными режимами [6, с. 63].

При совершении неповиновения осознанием военнослужащего охватываются следующие: 1) военнослужащий осознает, что он является подчиненным по званию или должности лицу, которое отдает приказ; 2) военнослужащий осознает, что приказ отдан в надлежащем порядке, в пределах полномочий командира и не противоречит действующему законодательству; 3) военнослужащий осознает свой служебный долг безоговорочно выполнять приказ командира (начальника), а также то, что он обязан доложить лицу, который отдал приказ о его выполнении.

Вторым интеллектуальным признаком умысла является предвидение наступления общественно опасных последствий. Под этим признаком следует понимать отражение в сознании человека тех событий, которые произойдут, должны или могут произойти в будущем. По мнению Б.С. Утевского, предвидение, в отличие от осознания, не может касаться настоящего, оно направлено только в будущее $[7$, с. 188]. При этом предвидение касается событий не в общем, а именно конкретной возможности или неизбежности наступления общественно опасных последствий. Конечно, предвидение наступления общественно опасных последствий находится в неразрывной связи с осознанием общественной опасности деяния, В так называемом осознании при- 
чинно-следственной связи между деянием и последствиями. Однако это осознание имеет общий характер и не распространяется, как верно замечает А.И. Рарог, на все детали причинно-следственной цепи [8, с. 20]. Следует согласиться с точкой зрения Р.В. Вереши, который разделил две степени предвидения наступления последствий: 1) необходимый и единственно возможный результат общественно опасного деяния (неизбежность) 2) в большей или меньшей степени возможный результат [9, с. 209]. При этом если речь идет о преступлениях, совершенных с прямым умыслом, как правило, лицо предвидит неизбежность (стопроцентность) наступления общественно опасных последствий, и только в отдельных случаях, когда выбранный способ совершения преступления прогнозирует в равной степени наступление различных последствий, возможно предвидение реальной возможности их наступления. Для косвенного умысла характерно только предвидение реальной возможности наступления общественно опасных последствий, как закономерное развитие причинно-следственной связи в конкретном случае. Принятие решения и его выполнение субъектом невозможны без понимания социального содержания совершенного и тех последствий, которые могут наступить. Принцип значимости поступка для индивида является основополагающим для избирательного поведения. Всякое действительно волевое поведение является избирательным актом, включающим сознательный выбор и решение. Преступление не бывает вынужденным, так как, обладая способностью к избирательности поведения, сознанием и волей, индивид всегда может воздержаться от противоправного поведения. А если деяния совершаются вынужденно, вследствие стечения крайне неблагоприятных обстоятельств, сужения сферы проявления воли, то уголовная ответственность, как правило, исключается. Ответственность за поведение предполагает, что у субъекта реально существовали варианты поведения и возможности его выбора, а с другой стороны, имелось субъективное осознание этих объективных возможностей и свободный выбор именно этого, а не другого поведения. Поэтому волевое деяние в юридической литературе определяется как осознанное целенаправленное воздействие человека на окружающий мир, как активное стремление лица добиться удовлетворения актуальной потребности, осуществление опре- деленной цели. По своей конструкции состав неповиновения является формальным, законодатель не указывает на последствия как на обязательный признак объективной стороны, и в соответствии с этим преступление считается оконченным с момента открытого отказа выполнить приказ начальника или фактического невыполнения приказа. Исходя из этого, интеллектуальный момент умысла ограничивается лишь осознанием общественной опасности своего деяния, отношение к последствиям (в форме предвидения), как считает В.А. Ломако, не возникает и не может возникнуть. [10, с. 160] С этой точкой зрения не согласился Р.В. Вереша, который доказывает, что при совершении преступления с формальным составом субъект, осознавая общественно опасный характер своего деяния, предвидит, что оно может повлечь негативные изменения в объекте преступного посягательства [11, с. 35].

Эта точка зрения, на наш взгляд, имеет право на существование, но с практической стороны предвидение наступления общественно опасных последствий неповиновения не требует доказательств.

В отличие от интеллектуального момента умысла, который всегда позиционируется как следствие познавательной деятельности человека и происходит исключительно в сознании лица, волевой момент умысла характеризуется направленностью воли субъекта преступления. УК Украины четко определен волевой момент прямого умысла - это желание наступления общественно опасных последствий и сознательное их допущение при косвенном умысле. Желание чего-либо - это опредмеченное стремление, которое направлено на соответствующий, конкретный предмет. Наличие желания всегда связано с возникновением и постановкой цели [12, с. 513]. Желанными, как верно заметил А.И. Рарог, являются не только те последствия, которые приятны виновному, доставляют ему внутреннее удовлетворение, но и те, которые при внутреннем негативном эмоциональном отношении к ним со стороны виновного лица являются неизбежными или необходимыми для удовлетворения потребностей, которые были побудительными причинами к действию [13, с. 101]. Эти последствия могут быть не только конечной целью лица, но и промежуточным этапом для достижения другой цели, средством для достижения конечной цели или сопроводительным неизбежным элементом деяния. Б.С. Никифоров, характеризуя 
волевое отношение лица к последствиям при прямом умысле, отмечал, что виновный относится к результату своего действия как нужному ему событию [14, с. 30]. Даже те последствия, к которым лицо не стремится, однако они являются побочным результатом деятельности субъекта, являются желанными для него с точки зрения формальной логики, если желание наступления конкретных последствий деяния сопровождается обязательным наступлением других последствий, которые не являются целью лица, эти последствия все равно являются желанными для субъекта. Исходя из этого, желание - это интеллектуально-волевой процесс, который начинается с осознания какой-либо потребности, а затем перерастает в направленность к достижению конкретной цели, выступает конечным результатом преступной деятельности. В отличие от прямого умысла, волевой момент косвенного (эвентуального) умысла характеризуется сознательным предположением наступления общественно опасных последствий. Это означает, что эти последствия не является целью лица, оно стремится к достижению других последствий, хотя и понимает высокую вероятность наступления именно тех последствий, которых оно не желало. Как уже отмечалось, неповиновение является преступлением с формальным составом, поэтому конструкция вины ограничивается психическим отношением лица к деянию. В науке уголовного права существует три точки зрения по поводу субъективной стороны преступлений с формальным составом. Большинство ученых категорически считают, что совершение этих преступлений возможно лишь с прямым умыслом [15, с. 99]. Некоторые криминалисты допускают возможность совершения преступлений с формальным составом с косвенным умыслом, относя сознательное допущение не к общественно опасным последствиям, а к социальным свойствам деяния, то есть его общественной опасности [7, с. 236]. Существует и третья точка зрения, согласно которой преступления с формальным составом иногда могут совершаться с неосторожной формой вины. И.М. Тяжкова считает, что субъективной стороной нарушение правил международных полетов может быть совершено как умышленно, так и по неосторожности [16, с. 154].

Представляется, что первая точка зрения, согласно которой преступления с формальным составом совершаются только с прямым умыслом, является наиболее обоснованной.
В преступлениях с формальным составом их общественная опасность связана с законодательным запретом действия или бездействия, потому что последствия находятся за пределами объективной стороны, определенная в диспозиции статьи, поэтому они (последствия) не могут быть предметом ни интеллектуального, ни волевого отношения.

Исходя из этого, волевое содержание умысла в этих составах исчерпывается волевым отношением к действию, совершение которого возможно только желать. Сознательного допущения к совершению деяния не может существовать вообще. Так что при совершении такого преступления, как неповиновение (иное умышленное невыполнение приказа), волевой момент умысла всегда направлен на нежелание выполнить приказ командира (начальника), то есть умысел может быть только прямым.

Прямой умысел на совершение неповиновения по времени возникновения может быть как заранее обдуманным, так и внезапно возникшим. Заранее обдуманный умысел характерен тем, что намерения на совершение преступления возникли за более или менее длительное время до их реализации и, по мнению многих криминалистов, этот вид умысла является более опасным, чем умысел, который возник внезапно. В целом соглашаясь с этой точкой зрения, следует отметить, что она характерна, как правило, для преступлений, которые могут быть латентными. Неповиновение по способу его совершения проявляется в открытом отказе от выполнения приказа и, как следствие, продолжительность соображений военнослужащего о невыполнении приказа командира в будущем никоим образом не влияет на степень общественной опасности деяния, это может показывать только устойчивую антисоциальную характеристику личности субъекта. Если возникновение потребности в совершении преступления, которая перерастает в образование мотива и формирование целей и направленности воли при заранее обдуманном умысле, возникает задолго до совершения преступления, то при умысле, который внезапно возник, промежуток между возникновением потребности и ее реализацией незначителен. Такой умысел, по определению А.И. Рарога, возникает под действием провоцирующего воздействия конкретной жизненной ситуации, в которой оказался субъект, и реализация этого умысла - или немедленная, или через небольшой промежуток времени $[17$, с. 8] 
Анализ судебной практики позволяет сделать вывод, что для большинства случаев совершения неповиновения характерен простой прямой умысел, который внезапно возник как реакция на приказ командира (начальника).

Выводы и предложения. Подводя итог, следует отметить, что неповиновение (иное умышленное невыполнение приказа) совершается с прямым умыслом, при котором военнослужащий осознает противоправность и общественную опасность открытого или скрытого отказа выполнить приказ командира (начальника) и желает не выполнить этот приказ.

\section{Список использованной литературы:}

1. Рарог А.И. Проблемы субъективной стороны преступления: учеб.пособие ; Московский юрид-ий ин-т. Москва : МЮИ, 1991. 90 с. С. 21.

2. Волков Б.С. Проблема воли и уголовная ответственность. Казань : Изд-во Казанского ун-та, 1965. C. 26-27.

3. Дагель П.С. Проблемы вины в советском уголовном праве. Ученые записки Дальневосточного университета. Владивосток, 1968. Вып. 21, ч. 1. 187 с. С. 14.

4. Шаргородский М.Д. Вина и наказание в советском уголовном праве. Москва : Юрид. изд-во НКЮ СССР, 1945.56 с. С. 6.

5. Панов М.І., Харитонов С.О. Суспільна небезпечність фундаментальна ознака поняття «кримінальне правопорушення». Юридичний Вісник України. № 16. Київ, 2019.

6. Кораблева С.Ю. Вина как уголовно-правовая категория и ее влияние на квалификацию преступлений : дис. ... канд. юрид. наук : 12.00 .08 ; Московский государственный лингвистический ун-т. Москва, 2013, 212 с. С. 63.
7. Утевский Б.С. Вина в советском уголовном праве. Москва : Гос. изд-во юридической лит-ры, 1950. 319 с. С. 187-188.

8. Рарог А.И. Вина в советском уголовном праве : монография. Саратов : Изд-во Саратовского ун-та, 1987. 186 с. С. 20.

9. Вереша Р.В. Теоретико-прикладні аспекти суб'єктивної сторони складу злочину : монографрія. Київ : Алерта, 2017. 568 с. С. 209.

10.Кримінальне право України. Загальна частина : підручник / за ред.: В. В. Сташис, В. Я. Тацій. 4-те вид., перероб. і допов. Харків : Право, 2010. 456 c. C. 160

11. Вереша Р.В. Кримінальна відповідальність медичних працівників за законодавством зарубіжних держав. Вісник Академії адвокатури України. 2013. № 3(28). С. 34-39.

12.Рубинштейн С.Л. Основы общей психологии. Санкт-Петербург : Изд-во «Питер», 2000. 712 с. C. 513.

13.Уголовное право. Общая часть. Преступление : акад. курс : в 10 т. / под ред. Н.А. Лопашенко. Москва: Юрлитинформ, 2016. Т. 7, Кн. 2: Субъективная сторона преступления. 400 с. С. 101.

14.Никифоров Б.С. Об умысле по действующему уголовному законодательству. Советское государство и право. Москва : Наука, 1965. № 6. C. 26-35.

15.Рарог А.И. Квалифрикация преступлений по субъективным признакам. Москва : Юрид. центр Пресс, 2003. 304 с.

16.Тяжкова И.М. Неосторожные преступления с использованием источников повышенной опасности. Санкт-Петербург : Изд-во «Юридический центр Пресс», 2002. 276 с. С. 154.

17.Рарог А.И. Уголовно-правовое значение заранее обдуманного умысла. Советская юстиция. 1986. № 11. С. 8-9.

\section{Shaposhnikov Yu. V. The subjective side of disobedience (Art. 402 of the Criminal Code of Ukraine)}

The article analyzes the views of forensic scientists regarding the subjective side of the crime under Art. 402 of the Criminal Code of Ukraine "Disobedience". The author believes that this problem has not been sufficiently studied, since in the monographic literature and in the comments to the criminal code, researchers limit themselves only to mentioning intent. At the same time, they do not specify what type of intent is inherent in this corpus delicti, and if they do specify, they do not argue their position. Developing the problem of the subjective side of disobedience, the author analyzed the opinions of various scientists regarding the content of intellectual and volitional signs of intent. It was concluded that when committing disobedience, a soldier realizes not only the social danger, but also the unlawfulness of his act, since he must know the provisions of military regulations. In cases where, due to various circumstances that do not depend on his will, the soldier was not familiar with the prescriptions of military regulations, we can not talk about the realization of the illegality of failure to comply with the orders of the commander (chief), and based on this, the public danger of these actions.

When committing disobedience, the awareness of a soldier covers the following: 1) a soldier realizes that he is subordinate in rank or position to the person who gives the order; 2) the soldier is aware that the order was given in the proper manner, within the powers of the commander and does not contradict the current legislation; 3) a soldier is aware of his official duty not only to unconditionally 
follow the order of the commander (chief), but also that he is obliged to report to the person who gave the order to carry it out.

Since the disposition of the composition of disobedience is constructed as a crime with a formal composition, the author considered three points of view regarding the subjective side of crimes with such a construction of the crime. It is concluded that the point of view of scientists who believe that crimes with a formal corpus delicti are committed only with direct intent is the most justified.

Key words: soldier, commander, chief, subordinate, disobedience. 


\title{
СУДОУСТРІЙ; ПРОКУРАТУРА ТА АДВОКАТУРА
}

\author{
UDC 347.965.48 \\ DOI https://doi.org/10.32840/1813-338X-2020.3.25
}

\author{
I. M. Legan \\ $\mathrm{PhD}$ in Economics, \\ Associate Professor at the Economic Security, Public Administration \\ Zhytomyr Polytechnic State University, \\ 6th year Master of Law \\ University of the State Fiscal Service of Ukraine
}

\author{
K. S. Bondarenko \\ Lecturer at the Department of Theoretical and Applied Linguistics \\ Zhytomyr Polytechnic State University
}

\section{FEATURES OF THE FREE LEGAL AID SYSTEM IN UKRAINE AND THEEUROPEAN UNION COUNTRIES}

The article is devoted to the study of the peculiarities of providing free legal aid in Ukraine and the European UnionCountries. The article reveals the evolution of theoretical ideas about the essence of free legal aid, ensuring the human right to free legal aid, reveals the role and place of free legal aid in the mechanism of protection of human and civil rights and freedoms, the principles of its provision in Ukraine and the European Union; the subjects of free legal aid and their legal services in the mechanism of ensuring human and civil rights and freedoms are analyzed; describes the legal status of the category of citizens who has the right to receive free legal aid to Ukraine, as well as the peculiarities of its provision in the European Union and who, as a rule, apply for such assistance to local centers for free secondary legal aid; international legal standards, experience of socially effective and high-quality free legal aid are compared with the system of free legal aid in Ukraine. The article proves that the state policy in the field of free legal aid is based on the relevant principles, namely: the rule of law; legality; availability of free legal aid; ensuring the quality of free legal aid; guaranteed state funding. Particular attention in the article is paid to clarifying the activities of the subjects of free legal aid in Ukraine and the categories of persons entitled to receive free primary and secondary legal aid. The article analyzes the features of the Law of Ukraine "On Free Legal Aid" in comparison with the legislation and practice of the European Court of Human Rights in recent years, UN documents, the conclusions of the Venice Commission. An approach is proposed according to which the subjective right to free legal aid includes a positive obligation of the state to provide it, which gives the state a sufficiently wide discretion to control the quality of such assistance. This, in turn, can pose certain threats to the advocacy independence. In addition, a large part of the population, and especially its vulnerable groups, still have a low level of legal awareness about solving their problems in a legal way, which stimulates corruption, inhibits the active participation of this part of citizens in economic life, provokes and supports poverty.

Key words: free legal aid, legal aid, legal support, realization of the right to assistance, advocacy institute, EU lawyer.

Formulation of the problem. Ensuring human rights and freedoms through access and the possibility of exercising the right of a citizen to free legal aid is today the defining criterion that characterizes the level of democratization of the state and soci- ety as a whole. Due to the European integration sentiments of modern Ukraine, scientific interest in this topic is caused by the urgent need for in-depth study of European law, convergence of national and European legal systems, improving oppor- 
tunities for close cooperation between Ukraine and the European Union. Analysis of the experience of foreign countries in the field of advocacy and legal aid provides opportunities to identify certain features of the functioning of these institutions in Europe, to assess areas and trends in their development, which are not typical for the Ukrainian advocacy, to identify advantages and disadvantages experience in this field in Ukraine.

The scientific interest is caused by the urgent need for in-depth study of the issues of adaptation of foreign experience in providing free legal aid in the countries of the European Union to the Ukrainian realities.

Analysis of recent research and publications. The following domestic scholars dealt with the issues of providing legal assistance in criminal proceedings: Alpert S.A., Bazhanov M.I., Biryukova A.M., Varfolomeeva T.V., Drozdov O.M., Zelenetsky V.S., Kaplina O.B., Korcheva T.V., Kuchevsky P.V., Leonenko V.V., Omelchenko T.V., Panchuk O.V., Pogoretsky M.A., Polyansky M.M., Popeliushko V.O., Tytarenko V.V., Trofimenko V.M., Changuli G.I., Shibik V.P., Janowska O.G. and others. Despite the prevalence of discussions on this issue, some aspects of the provision of free legal aid have not been explored.

The aim of the article is a comprehensive analysis of the institute of free legal aid in Ukraine and the European Union, identification of existing shortcomings in the functioning of this institute in Ukraine, study the possibilities of applying the best examples of best practices of progressive countries in Ukraine.

Presenting main material. The right to free legal aid guaranteed by Article 59 of the Constitution of Ukraine in the context of promoting the wide access of every citizen to justice and ensuring effective protection of human rights has long required state support and final implementation.

Due to the inconsistency of the provision of free legal aid in Ukraine with world and European standards, on June 9, 2006 the President of Ukraine approved the Concept of formation of the system of free legal aid in Ukraine. The task of this Concept was to create a system that can provide real and effective access to free legal aid.

The next step, and in fact the starting point for the creation of a system of free legal aid in Ukraine was the adoption on June 2, 2011 by the Verkhovna Rada of Ukraine of the Law of Ukraine "On Free Legal Aid", according to which every citizen, including foreigners and stateless persons, is guaranteed for free legal aid.
According to this Law, free legal aid is "legal aid guaranteed by the state and fully or partially provided at the expense of the State Budget of Ukraine, local budgets and other sources" [2].

In the context of Part 2 of Article 59 of the Constitution of Ukraine [5], guaranteeing everyone the right to legal aid is not only a constitutional and legal obligation of the state, but also a confirmation of Ukraine's compliance with international legal obligations under the Universal Declaration of Rights. 1948, the Convention for the Protection of Human Rights and Fundamental Freedoms of 1950, the International Covenant on Civil and Political Rights of 1966, and others.

The Law of Ukraine "On Free Legal Aid" provides for two types of such assistance: primary and secondary.

The essence of primary legal aid includes the provision of consultations and preparation of applications and complaints for a person, except for procedural ones (those addressed to the court) (Article 7).

Secondary legal aid consists in drawing up documents of procedural character, realization of representation of interests in courts, other state bodies, local governments before other persons; defense against prosecution (Article 13).

On June 6, 2012, the Cabinet of Ministers of Ukraine adopted the Resolution "On the Establishment of the Coordination Center for Legal Aid and Liquidation of the Center for Legal Reform and Draft Law at the Ministry of Justice", which provided for the establishment of the Coordination Center for Legal Aid and approves its Regulations.

On July 2, 2012, the Ministry of Justice of Ukraine issued Order № 968/5 “On Establishment of Centers for Free Secondary Legal Aid", according to which existing Centers were established at the main departments of justice in the Autonomous Republic of Crimea, oblasts, Kyiv and Sevastopol. Today, the Centers for Free Secondary Legal Aid operate in all regional centers of Ukraine under the main departments of justice.

The main task of such centers is to ensure the right of citizens to protection from prosecution in criminal proceedings, including the representation of the interests of individuals during both criminal and administrative detention.

From July 1, 2015, in addition to legal aid centers in regional centers, about 100 inter-district legal aid centers began to operate. They provide legal assistance to low-income citizens in civil or administrative cases. 
The state mechanism of the free legal aid system in Ukraine is based on such key principles as the rule of law, legality, availability of free legal aid, quality assurance of free legal aid and guaranteed state funding.

The legal systems of the European Union provide a number of mechanisms for providing free legal aid.

In many countries, legal aid law describes free legalaidasservices provided to detainees, suspects, accused and defendants in criminal proceedings, and legal aid in other categories of cases (for example, the United Kingdom and Slovenia). In some countries, such as Slovenia, legal aid schemes in criminal cases and aid in other categories of cases are established by separate sets of legislation.

The experience of the United Kingdom is also noteworthy, where partial free assistance for a certain group of low-income people is also practiced. That is, if the person applying for legal aid has funds, according to the decision of the commission on additional appropriations of the Ministry of Social Security or the court, the decision to provide appropriate legal aid is issued after the applicant has paid a certain amount. Given the large number of appeals to local centers for free secondary legal aid to provide legal assistance to protect illegal rights or claims, such a rule may provide some responsibility for the client's claims and the number of lawsuits.A similar rule exists in the legislation of other countries. The bottom line is that when citizens apply for free legal aid, they are required to provide proof of their poverty, and depending on the level of income, legal aid is provided either free of charge or through co-financing of $20 \%, 40 \%, 70 \%$ or $100 \%$. In the Netherlands, the activities of private lawyers are complemented by a strong advisory sector, such as voluntary, so-called "legal shops", legal aid offices and legal aid centers. Legal aid offices provide priority legal assistance, advice on social security, housing, employment, immigration and consumer protection; refer principals to private lawyers, providing certificates entitling to subsidized legal aid to persons who has applied to private lawyers. Such Offices are funded by the Ministry of Justice of the Netherlands and employ law graduates. In the case of automatic appointment of a lawyer, payment for his services is made by the judicial authorities. People who have an income exceeding the established level are not entitled to apply for financial support from the state and pay for services at their own expense. They can use the institution of legal aid insurance.
According to independent international experts, the legal aid system in Ukraine has taken important steps to raise awareness of the right to legal aid. According to the evaluation, Ukrainian legislation and bylaws meet the standards of the European Convention on Human Rights regarding the choice of a lawyer. In Europe, too, more and more attention is being paid to ensuring the proper quality of legal aid. In Ukraine, there is an appropriate regulatory framework for criminal proceedings. However, it is recommended to strengthen the quality control mechanisms, in particular, by expanding the norms that establish the quality standards of legal aid in civil and administrative cases.

Obviously, without ensuring the right to legal aid in the context of continuous legislative reform, it is hardly possible to effectively protect all other human rights and freedoms. And in this context it should be noted that the right to legal aid has a dual nature: on the one hand, it exists as a subjective private human right, and on the other - it is the most important guarantee of protection of all other rights and freedoms [6, p. 8]. The mechanism of constitutional guarantee of the right to legal aid should be considered as an element and a specific specification of the mechanism of legal regulation of the realization of fundamental human rights and freedoms.

Conclusions and suggestions. Implementation of the strategy of improving the system of free legal aid in Ukraine, in our opinion, requires a number of measures, including: expanding access of citizens to quality free primary and secondary legal aid in accordance with the existing needs throughout Ukraine; creation and functioning of new points of access to free legal aid; expansion of the list of people who will have the right to receive it; formation of a flexible system of free legal aid that promptly responds to the legal needs of the community; increasing the level of legal capacity of territorial communities and the legal consciousness of citizens, reducing the level of corruption at the household level; development of a network of independent free legal aid providers that will actively interact with each other on the basis of partnership and free competition; creation of an effective system of professional development, generalization and dissemination of best practices and ensuring the exchange of experience for employees of the free legal aid system, prosecutors, law enforcement agencies, courts, lawyers, NGOs, volunteer movements, etc. At the same time, it is necessary to improve the current legislation in the field of free legal aid in terms of formulating the responsibilities of the subjects 
of the right to free secondary legal aid and consideration of the conceptual possibility of co-financing, taking into account the financial situation, clients of legal aid services.

Thus, the existence of a free legal aid system in Ukraine is undeniable, but much remains to be done to ensure that Ukraine reaches the level of world standards of social, legal and democratic life that will enable it to feel equal among other rule of law states.

\section{References:}

1. Bova E. Organization of free legal aid in Ukraine: dissertation abstract for the degree of candidate of legal sciences. Academy of Advocacy of Ukraine. Kyiv [b.v.], 2009. P. 20.

2. Bova E. Organization of free legal aid in Ukraine: author's ref. dis.... Cand. jurid. Science : 12.00.10. Kyiv, 2009. 21 p.

3. Law of Ukraine "On Free Legal Aid". Bulletin of the Verkhovna Rada of Ukraine of 08.07.2011. № 3671-VI.
4. Isakova V.M. The right to legal aid: concepts, features, guarantees: author's ref. dis ... cand. jurid. Science : 12.00.01. Kharkiv, 2013. 19 p.

5. The Constitution of June 28, 1996. K. : Publishing House Law. 1996. St. 59.

6. Criminal Procedure Code of Ukraine: Code of Ukraine of April 13, 2012. № 4651-VI / Official site of the Verkhovna Rada of Ukraine. URL : https://zakon.rada.gov.ua/laws/show/4651-17/ print1433742953674692.

7. Resolution of the Cabinet of Ministers of Ukraine "On the establishment of the Coordination Center for Legal Aid and the liquidation of the Center for Legal Reform and Draft Law under the Ministry of Justice" of June 6, 2012 № 504 / Official website of the Verkhovna Rada of Ukraine. URL : https://zakon.rada.gov.ua/ laws/show/504-2012-\%D0\%BF\#Text.

8. Shramko Yu. T. Constitutional right to legal aid in Ukraine: current issues of legislative regulation: author's ref. dis. ... Cand. jurid. Science : 12.00.02. Kyiv, 2016. 18 p.

\section{Леган І. М., Бондаренко К. С. Особливості системи безоплатної правової допомоги в Україні та країнах Європейського Союзу}

Стаття присвячена дослідженню особливостей надання безоплатної правової допомоги в Україні та країнах Європейського Союзу. У статті розкрито еволюцію теоретичних уявлень сутності безоплатної правової допомоги, забезпечення права людини на безоплатну правовудопомогу, розкрито роль та місце безоплатноїправовоїдопомоги в механізмі захисту прав і свобод людини і громадянина, принципи її надання в Україні та країнах Європейського Союзу; проаналізовано суб'єкти надання безоплатної правової допомоги та їх правові послуги в механізмі забезпечення прав і свобод людини і громадянина; охарактеризовано правовий статус категорії громадян, які мають право отримати безоплатну правову допомогу Україні, а також особливості їі надання в країнах Європейського Союзу і які, як правило, звертаються за такою допомогою до місцевих центрів із надання безоплатної вторинної правової допомоги; зіставлено міжнародно-правові стандарти, досвід соціально ефективного та якісного надання безоплатної правової допомоги із системою надання безоплатної правової допомоги в Україні. У статmі доведено, що державна політика у сфері надання безоплатної правової допомоги грунтується на відповідних принципах, а саме: верховенства права; законності; доступності безоплатної правової допомоги; забезпечення якості безоплатної правової допомоги; гарантованого державного фрінансування. Особливу увагу у статті приділено з'ясуванню діяльності суб'єктів надання безоплатної правової допомоги в Україні та категорії осіб, які мають право отримати безоплатну первинну та вторинну правову допомогу. У статmі проаналізовано особливості Закону України «Про безоплатну правову допомогу» у співставленні із законодавством та практикою Європейського суду із прав людини останніх років, документами ООН, висновками Венеціанської Комісії. Запропоновано підхід, зәідно з яким суб'єктивне право на безоплатну правову допомогу включає позитивний обов'язок держави з ї̈ забезпечення, що надає державі достатньо широкі дискреційні повноваження щодо контролю за якістю такої допомоги. Це, у свою чергу, може створювати певні загрози для незалежності адвокатури.

Ключові слова: безоплатна правова допомога, юридична допомога, правовий супровід, реалізація права на допомогу, інститут адвокатури, адвокат ЄС. 


\section{ФІЛОСОФІЯ ПРАВА}

УДК 340.112; 349; 34.02

DOI https://doi.org/10.32840/1813-338X-2020.3.26

Я. Я. Мельник

адвокат, доктор юридичних наук, старший науковий співробітник (керівник наукової теми НДР № 20БФ042-01)

Інституту права Київського національного університету імені Тараса Шевченка,

професор кафедри державно-правових та галузевих дисциплін Київського університету права Національної академії наук України

\section{АНТРОПОГЕНЕЗ МІГРАЦІЙНИХ ПРОЦЕСІВ У ПРИЗМІ ПОСТМОДЕРНУ СОЦІАЛЬНОГО ПРАВА}

У статті розглядається антропогенез міграційних процесів під призмою постмодерну соціального права. Робиться акцент на тому, що міграційні процеси не тільки мають багатогранний, міждисциплінарний характер виникнення у свій причинній появі як френомен, але й тісно а, подекуди, прямо головним чином пов'язані зі станом соціальної безпеки в державі, власне, із правовою моделлю держави та ї̈ здатністю забезпечувати належний рівень соціальних права у країні. Автор, аналізуючи численні статистичні дані, судову практику та наукові доробки у сфрері фрілософрії права та соціального права, вбачає стійкий зв'язок міграційних процесів із ментальною втратою установки людини у справедливість соціального режиму та правопорядку, що тягне за собою зникнення/невизнання себе як повноцінного учасника правовідносин в державі. Як наслідок, соціально-правові коливання, коливання в нестабільності правової визначеності, забезпечення верховенства права, нестабільність і прояв криз, соціальних ризиків не дають можливості якісно планувати майбутнє як громадянина, бути гідним та достойним у світлі декларованих принципів права. У таких умовах громадянин-мігрант втрачає не що інше, як правовий/юридичний сенс реалізувати своє життя у цій країні. У зворотному зв'язку це негативно позначається на державній соціальній політиці, на спроможності держави виконати свої соціальні функції, а вслід за цим - слідує втрата людського потенціалу. Це позначається негативним чином на фрінансово-соціальні сфрері, на сффері ринку праці тощо. Також у зв'язку з активізацію міграційних процесів змінюється рельєф та кон'юнктура соціального права, адже, з одного боку, внаслідок його реконструкції відбувається перебудова юридичної конструкції та сенсу соціальних прав в державі. Відтак автор доводить, що міграційні процеси є перманентним елементом антропогенезу сочіального права.

Автор приходить до висновку в тому, що соціальна та правова держава повинна мати ефрективно діючий інструмент для забезпечення соціальної стабільності та соціальної безпеки на тлі міграційних процесів, а власне відповідну стратегію, визнану та прийняту на державному рівні.

Ключові слова: міграція, соціальна безпека, соціальні права, антропологія права, постмодернізм права, фрілософрія соціального права, COVID-19.

Постановка проблеми. Міграційні процеси характеризують себе насамперед як соціальні процеси, адже за своєю формою вони відображають трансформацію в державі соціальної політики. Водночас вони завжди вказують на виникнення, зміну і припинення соціаль- них та трудових правовідносин між їх суб'єктами. Де-юре та де-факто міграційні процеси стосуються таких суб'єктів права, як держава та громадяни, особи без громадянства, біженці, а також внутрішньо переміщені особи та внутрішні мігранти. 
Слід віднайти за очевидне і те, що у своїй основі міграційні процеси відображають внутрішній стан не тільки соціальної, але й безпекової політики в державі. Одночасно міграційній процеси є й відображенням благосприятливих, неагресивних режимів забезпечення прав, свобод та інтересів, забезпечення балансів між публічною та приватно-правовою сферами, стосовно стану безпеки держави та права.

В Україні, із часів її незалежності, враховуючи статистичні дані $[14 ; 11$; тощо], спостерігається тривалі міграційні процеси, що становить значну проблему з точки зору соціального права. Адже через від сутність належного дослідження неможливо прогнозувати розвиток соціального законодавства у протидії процесам міграції, забезпечити належний контроль міграції, власне, як і не має належної можливості забезпечити соціальну стабільність та прогнозованість у державі. Це і становить предмет даного дослідження.

Аналіз останніх публікацій і публікацій. Проблема міграційної політики у праві, іï впливу на соціальну політику, безумовно, не $\epsilon$ новою в сучасних дослідженнях. Зокрема, цими проблемами переймались ряд вітчизняних та закордонних дослідників, як і вітчизняних та міжнародних організацій здійснюють постійний моніторинг процесів міграції. Серед вчених - О.Н. Ярмиш [27, с. 3-9], О.А. Малиновська [9; 10], Б.М. Юськів [4], О.В. Махонюк [13], І.С. Сахарук [20, с. 587-110], Л.М. Сіньова $[21$, с. 494-519], Р.І. Коваленко [7, с. 129144] тощо; серед громадських організацій «Ла Страда», «Платформа прав людини» [17] тощо. Деякі проблеми були окреслені нами в попередній публікації [16-а].

Зокрема, основоположник вітчизняної історичної школи права О.Н. Ярмиш, досліджуючи дану проблему, приходить до висновку, що пізнавальні сюжети міграційних процесів мають змішаний - як історико-правовий, так і одночасно загальноісторичний характер. Адже, на думку вченого, як і у житті, фрорма і зміст нерозривні, правове тісно переплетена із соціальним, виражає і оформлює його. Міграційні процеси державо- і правоутворюючі чинники. Водночас вчений констатує, що спектр підходів тут широкий - від пасіонарності націй та народностей до дослідження міграцій як «переміщення» носіїв правової свідомості й правової культури. А одним із методів дослідження цієї проблеми вважає метод юридичної антропології у дослідженні міграційних процесів як державо- і пра- воутворюючого чинника. Оскільки він може принести чимало нових, i, можливо, несподіваних результатів [27, с. 9]. Такий підхід, таки дійсно, якраз якнайяскравіше відображає усю палітру складності проблеми та її багатогранність, а вслід за цим дає можливим бачити проблему під соціальним та державотворчим кутом зору, а спосіб її дослідження - під призмою фрілософрії права, власне антропології та постмодерну.

Водночас на тлі різних соціальних ризиків та фракторів у 2020 році гостро постала наступна причина каталізатора міграційних процесів пандемія Covid-19, що тісно пов'язана із соціальною політикою, забезпеченням стабільності та безпеки в державі в соціальному, міграційному та національному рівнях і проявах.

За таких висновків стає очевидною неминучий вплив соціальної сфрери на фрінансову систему країни, яка повинна бути здатною (а) втримати мігрантів аби залишити в країні необхідну робочу силу та людський потенціал; (б) здатною бути забезпечити соціальні умови поверненням, мінімізувати ризики безробіття, забезпечення гідних умов праці; (в) протистояти загрозам та викликам соціальної безпеки, безпеки здоров'ю людей тощо.

О. Кривицька небезпідставно вбачає у процесах міграції насамперед вияв одного з етнічних маркерів, що позначається на системі міжетнічної взаємодії та ризиків, спричинених процесом інтеграції «чужих» етносів вукраїнський соціум [8, с. 79]. Така позиція містить очевидно відображає прогностично-фрілософрський змісту проблеми. Водночас вчена, досліджуючи міграційні процеси в Україні, конфрлікти ідентифрікації та ризики «відторгнення», приходить до висновку, що серед гострих питань соціально- економічного розвитку України, що пов'язані з міжнародною міграцією, необхідно виділяти такі: втрату демографрічного потенціалу; посилення міграційного відпливу внаслідок невідповідності попиту і пропозиції на національному ринку праці; втрату трудового та освітньо-кваліфікаційного потенціалу; необхідність стимулювання зворотних міграційних потоків та формування людського потенціалу реемігрантів; розробку заходів із використання грошових переказів мігрантів; боротьбу з нелегальними міграційними потоками; інтеграція іммігрантів [8, с. 88]. Зворотність міграційних потоків на сьогодні відобразилась в аналітичній записці вченої О.А. Малиновської.

Зокрема, вчена, досліджуючи впливи пандемії Covid-19 на трудову міграцію громадян України та визначаючи можливі напрями державного 
реагування, констатує: «...одним із важливих наслідків карантинних заходів, введених у більшості країн світу у відповідь на пандемію COVID-19, $\epsilon$ неможливість виїхати на сезонні заробітки та повернення в Україну трудових мігрантів. Це може призвести до посилення напруженості на національному ринку праці та збільшення навантаження на систему соціального захисту і вимагає зваженої та системної реакції держави. Заходи, спрямовані на мінімізацію ризиків від повернення заробітчан та використання позитивного потенціалу поповнення робочої сили для національної економіки, мають бути як невідкладного, так і стратегічного характеру, здійснюватися і на внутрішньополітичному, і на міжнародному рівні ... » [11]. А за прогнозом НАНУ (відмічає Київська міська державна адміністрація - Я.М.), в Україні коронавірусом може заразитися 22 млн. людей [5].

Власне, в підтвердження таких даних та висновків здалось навести такі статистичні та аналітичні дані отримані громадськими організаціями, що переймалися проблемами міграції.

Так, за даними громадської організації «Платформа прав людини», відстежуються й економічні наслідки пандемії для жінок-мігранток. Зокрема, відповідно до Світового звіту про міграцію МОМ за 2020 рік, жінки-мігрантки становлять близько 74\% сфери послуг, що включає домашню роботу та піклувальну працю, і в багатьох випадках $є$ соціально незахищеними. Значна частина доходів жінок-мігранток спрямовується на підтримку їх сімей у своїх країнах. Також під час спалаху COVID-19 обмеження мобільності та подорожей ставлять під загрозу доходи жінок-мігранток, особливо домашніх працівниць [17]. Немаловажливими соціально-кризовим фрактором вважається й збільшення випадків домашнього насильства. І це все через обмеження мобільності та запровадження карантинів наслідок чого посилюється гендерне насильство, невизначеність праці та міграції, а також соціальним дистанціюванням [17].

За даними громадської організації «Ла Страда» (згідно інформації ГО «Платформа прав людини» - Я.М.), за місяць карантину з 12 березня по 12 квітня 2020 на Національну гарячу лінію 3 попередження домашнього насильства, торгівлі людьми та ґендерної дискримінації надійшло 2051 звернення стосовно домашнього насильства. Для порівняння: за лютий надійшло 1273 звернення. 86,6\% це звернення від жінок [ 17].
ГО «Платформа прав людини» також зазначає, що на роботу з України до Італії їдуть переважно жінки (пише Європейська правда ГО «Платформа прав людини»). Серед 234 тисяч українських мігрантів, які на кінець 2018 року мали дозвіл на проживання в Італії (234 тис.), 80\% - жінки. При цьому кожна четверта (27\%) з них - старша за 60 років (дані Євростату) [17].

Під час епідемії у сфері трудової міграції склалася унікальна ситуація, яка об'єктивно приводить до зростання ролі урядів і централізації процесів. Насамкінець, відмічається, що така ситуація приверне увагу уряду до побудови реальних і життєздатних програм реінтеграції трудових мігрантів, та зокрема, жінок [17].

У попередніх аналітичних замітках вітчизняної преси цілком виправдано зазначалося, що в найближчі роки міграційні процеси в Україні посиляться за рахунок високого попиту на кваліфіковану робочу силу, а через кілька десятків років дефіцит кадрів в Україні загрожуватиме економічній безпеці держави [15]. Таку загрозливу тенденцію помітила перший заступник міністра соціальної політики О. Крентовська (за даними УНІАН). Однак, на її думку (з огляд на час публікації - Я.М.), зростання нестачі кваліфокованих працівників не було критичним у силу недостатнього рівня економіки. Водночас, за словами О. Крентовської, в інших країнах вже почалась конкуренція між собою за залучення працівників. До прикладу, попит на українських заробітчан найбільше зростає в Польщі, Словаччині, Литві і Хорватії. Так, за підрахунками Союзу підприємців і роботодавців Польщі, для підтримки зростання економіки цієї країни необхідно залучити 5 млн. емігрантів, а загальна кількість виданих запрошень на роботу в 2018 році для українців складе 3 млн. [15].

Зрештою не було б зайвим і навести статистичні дані про скорочення населення України. Так, серед численних показників кризовим та очевидно небезпечним фактором (за даними станом на 2011 та 2012 рр.), залишається до уваги зовсім не втішний прогноз скорочення чисельності населення України. Адже до початку гібридної війни на Сході та окупації АРК чисельність населення України повинна скоротитися в період з 2010-2050 рр. із 46 млн. до 34 млн. (дані станом на 2012p.) [14, с. 10].

На основі вищезазначеного було б доцільним звернути увагу на стан судової практики в контексті міграційних процесів. Зокрема, судова практика ЄСПЛ в контексті міграційної політики здебільшого сфокусована переважно стосовно 
таких питань: «...справа «Бах проти Великобританії», за якою ЄСПЛ визначив, що міграційний статус може бути віднесений до «інших ознак», за якими стаття 14 Конвенції забороняє необґрунтовану дискримінацію ...[18]»; «...справа «Д. проти Сполученого Королівства», де у заявника була пізня стадія захворювання ВІЛ/СНІД. Суд вказав, що висилка заявника у країну походження, де відсутній достатній рівень медичного обслуговування та лікування в подібних випадках, а також де відсутні родичі та друзі, які б мали змогу доглядати за заявником, прирівнюється до нелюдського поводження, яке заборонено у відповідності до ст. 3 Конвенції; .... справа «Н. проти Сполученого Королівства» у якій ЄСПЛ наголосив, що в таких випадках мова має йти про виключні обставини і переконливі гуманістичні міркування. Суд вказав, що іноземці, які підлягають висилці, не можуть загалом претендувати на право залишатися на території однієї 3 держав лише для того, щоб продовжувати користуватися медичною, соціальною чи іншою допомогою або послугою, а рішення про видворення іноземця, що страждає на серйозну психіатричну чи фрізичну хворобу в країну, де засоби для лікування цієї хвороби поступаються засобам доступним заявнику в країні перебування може бути проблематичним з точки зору статті 3 Конвенції лише у виключних випадках; справі «Пономарьови проти Болгарії», суд роз'яснив, що стаття 2 протоколу 1 не може трактуватися як така, що передбачає обов'язок держави по створенню та фрінансуванню конкретних освітніх закладів, проте кожна держава зобов'язана надати доступ до тих освітніх закладів, що існують ....» [18].

Враховуючи аналіз правової доктрини та судової практики, проблема міграційних процесів стосовно соціального права очевидно вказує на вияв певних постмодерністських проблем.

Важливим у цьому ключі $є$ ряд позицій, що опубліковані у збірнику «Інтелектуальних хронік пандемії» (Джорджо Агамбен, Жан Люк Нансі, Славой Жидек, Патайотис Сотрис, Ален Бадью, Поль Б. Пресьядо, 2020) [6]. Адже вчені якраз замислюються не стільки над проблемою статистики, скільки над проблемою зміни цінностей в суспільстві. Зокрема, звертають увагу на проблему «соціального дистанціювання», «на біополітику», на те, що «наука стала новою релігією» сьогодення, на виникнення «м'якої тюрми як теле республіки»; піднімають питання навчально-освітні, а також співвідносять питання «підкорення чи мутації?».
Таким чином, попри спроби розібратись та ґрунтовно проаналізувати ключові глобальні проблеми, на цьому тлі залишився відкритими безпосередньо питання зв'язку соціального права із постмодерном права, постмодерном права із міграцією. Як наслідок, наукова спільнота фахівців із соціального права у таких умовах очевидно позбавлена належного критичного аналізу міграційних процесів та стану розвитку соціального права, що і спонукає нас поставити відповідну мету у цьому дослідженні.

Мета дослідження полягає в тому, щоб осмислити міграційні процеси у призмі постмодерну соціального права. Це надасть можливість з'ясувати антропологічні особливості зміни соціального права в частині міграційних процесів, визначити більш ґрунтовно проблеми взаємозв'язку та адаптації держави до вироблення якісного соціального законодавства, розвитку доктрини соціального права, забезпечення соціальних прав осіб-мігрантів, i, що головне - збагнути антропологічну суть буття людини у правовій реальності, кон'юнктури соціального права.

Виклад основного матеріалу. Досліджуючи дану проблематику, насамперед слід вказати на те, що деякі фрілософи-дослідники правового постмодерну як філософрсько-правового дискурсу схиляються до позиції про відсутність підстав вважати продовження дії постмодерну.

Зокрема, професор Б. Мелкевік (Канада) зазначає, що постмодернізм за своїм «прощанням із розумом» по суті спрямовує юридичну думку на шлях нормативного скинення права, що ми вважаємо антиюридичним. Він утягує ніби нас в естетичний нігілізм, що змішує самобутню роль артиста із сукупними ролями, пов'язаними з модерною юридичною практикою. У такий спосіб юридичний постмодернізм - лише вираження всезагального нігілізму. Постмодерн, з його позиції, заперечуючи будьякі міркування практичної фрілософії стосовно легітимної та нелегітимної влади, справедливості та несправедливості, законності та незаконності, нормативності та фактичності, роззброює нас перед вимогами спільного життя, особливо в громадському, державному або світовому плані. Зважаючи на те, вчений доводить, що немає логічного місця для таких міркувань, у нас немає більше жодної інстанції, аби боротися проти сил, що несуть людству небезпеку або не бажають поважати його. Зрештою, вчений приходить і до такого висновку, який вказує на те, що юридичний постмодернізм відчиняє двері будь-якому свавіллю. Постмодернізм 
не може жодним чином практично проявитися в праві. Оскільки постмодернізм нехтує питанням смислу в праві, будь-яка правова практика стає непотрібною, якщо навіть не марною. Не будучи здатним нести практичну відповідальність у сорері права, юридичний постмодернізм презентує лише естетичний вихід за межі практичного світу [16, с. 227].

Н.В. Маліновська, досліджуючи питання постмодерну а герменевтики, відмічає, що філософрія модерну збула заснована на ідеї Просвітлення, та відбувалась під знаком владарювання Суб'єкту. ІІї основні результати - торжество Розуму, абсулятизація наукових досліджень, віра в прогрес та інновацію, відособлення людини від пов'язаного її із сакральним початком. Усе це сприяло розвитку принципу суб'єктивності [12, с. 80].

У контексті постмодерну права О.О. Бандура зазначає, що умови для повноцінного життя особистості може створити тільки суспільство. На його думку, найвищою людською цінністю виступає особистість не в ізольованому від суспільства стані, а саме в єдності з ним. Відтак учений приходить до висновку, що права людини повинні відображати насамперед внутрішню узгодженість, гармонію взаємних зв'язків особистості із соціумом. Ця обставина поки що не враховується постмодерністською філософією права повною мірою [2, с. 254].

Водночас у ключі проаналізованої вище проблеми, насамперед, можливо відстежити певну ієрархічну асиметрію конструкції держави із відносно не стійкою правовою системою, правосферою, що не здатна забезпечити сприятливий соціальний клімат.

3 іншого боку, проявляється аморфний соціальний стан, що притаманний міграційним процесам громадянина-мігранта як суб'єкта права, а також і певних соціальних груп, перебуваючих у міграційних процесах (біженці, переселенці, внутрішньо переміщенні особи). При цьому, як уявляється, міграційні процеси характеризують себе скоріш як певні «аморфні» ${ }^{1}$ стани, в силу

\footnotetext{
1 Для довідки: Амо́рфные вещества́ (тела́) (от др.-

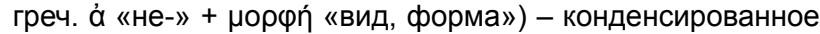
состояние веществ, атомная структура которых имеет ближний порядок и не имеет дальнего порядка, характерного для кристаллических структур. В отличие от кристаллов, стабильно-аморфные вещества не затвердевают с образованием кристаллических граней, и, (если не были под сильнейшим анизотропным воздействием - сжатием или электрическим полем, например) обладают изотропией свойств, то есть не обнаруживают различия свойств в разных. Див.: [1].
}

того, що постають як певні найближчі порядки та не містять у собі певної чітко визначеної «решітки», тобто не є структурованими. Вони засновуються на тих чи інших первинних фрагментах потреб природного права, що супроводжуються соціальними інтересами, комплексними соціальними правами, тощо. Аморфність, як прояв «не системності», у свою чергу, надає нам можливість звернути увагу на антропологічні та постмодерністські особливості міграційних процесів. По суті, з'ясувати спосіб впливу міграційних процесів на ре(де)конструкцію конкретної моделі соціального права держави, до якої/від якої/ відбувся міграційний процес. Тобто від «ближнього-аморфного» - до «структурного, системного, правового державного рівня» (Я. М.), тобто рівня чіткого ієрархічного правового порядку регулювання міграційних процесів. Водночас саме «спосіб буття соціального права» і стосується у своїх засновках антропологічного виразу проблем права в контексті міграційних процесів, як перехідних станів де(ре)формування права.

3 точки зору соціальної метафізики, як певного способу осмислення суспільства, що побудована на принципі максимальної абсолютизації того чи іншого явища, визначається, що сам «... структуралізм переконливо доводить, що без структури не має системи, і навпаки, будь яка система існує, відтворюється лише настільки, наскільки функціонує її структура, або якщо в її основу закладена відносно стійка модель функціональних зв'язків та відносин...» [19, с. 25].

Н.В. Маліновська, беручи до уваги термін «деконструкція» права (по Ж. Дерідда), доводить, що його сенс являється одним із яскраво характеризуючи лінгвістичної парадигми постмодерна термінів та зводиться до нівації будь якого тексту. Слід погодитись із дослідницею у тому, що даний прийом бере свій початок у запереченні сенсу буття, а, відповідно, в сенсі будь якого тексту, який може бути реконструйований шляхом вказівки на численні переноси його значень, його невідповідності самому собі. У результаті такого підходу відбувається доповнення філософської ідеї герменевтичного кругу, що зрештою вказує на безкінечність одного тексту під впливом іншого, а другого під впливом третього, і т.д. [12, с. 86].

Такий підхід дає нам можливість сфокусувати увагу на тому, що міграційні процеси так чи інакше супроводжуються різного роду побіжними мікропроцесами, що не можуть не стосуватися необхідності забезпечення структуровано- 
сті, системності. Забезпечення структуралізму в міграційних процесах $€$ важливим питанням в силу того, що вони такі процеси здійснюють вплив на внутрішню та зовнішню соціальну політику держави, її правову культуру, правовий порядок, тощо; з іншого боку, очевидним $€$ й потреба відстеження тісного взаємозв'язку з певним проявом системності стосовно ре(де) конструкції соціального права на доктринальному рівні, що дістає свій особливий вияв від трансформуючого соціального порядку - до з'ясування зміни його кон'юнктури та умов. На наше переконання, для більш всебічного дослідження проблем міграційних процесів у соціальному праві слід керуватися тими основними підходами, які нададуть можливість відстежити правову природу соціального буття людини, відстежити причини зміни основних інтересів, що пов'язанні з міграційними процесами. Як уявляється, це можливо з'ясувати завдяки застосуванню антропологічного методу та при постмодерністському підході при вирішенні проблем соціального права в міграційних процесах.

У фрілософрії права цілком виправдано відстоюється позиція стосовно того, що держава $€$ насамперед синтезом сім'ї та громадянського суспільства. Адже вона розгортається у тріаді: (1) ставлення держави до своїх громадян (внутрішня політика і конструкція); (2) відносини держави з іншими державами; і (3) перехід держави у світову історію [24, с. 81].

Європейська правова соціальна держава у свій час взяла на себе цивілізаційні функції забезпечення населення роботою, соціальний патронаж, життєві та цивілізаційні стандарти для найменш захищених категорій людей, втілювала державні та муніципальні програми для різних соціальних груп та регіонів, а суспільство тред-юніоністські об'єднання сприяли модернізації, стежили за втіленням в життя громадянських та соціальних прав [23, с. 147]. Водночас у процесі еволюції взаємовідносин держави та громадянського суспільства виникає простір для боротьби двох тенденцій. Тут, панує певна думка стосовно того, що через тривалу теоретичну рефрлексію та соціально-історичну практику просвітництва суспільством та державною бюрократією все більше усвідомлюється необхідність не обмежуватись визнанням цивільних та політичних прав, а сприяти набуттю комплексних прав, що охоплюють цілий спектр від права на мінімум економічного добробуту й безпеки до права мати повноцінний доступ до освіти, охорони здоров'я, соціальної спадщини в цілому та жити життям цивілізованої істоти відповідно до стандартів, що панують в суспільстві $[28$, с. $75 ; 23$, с. 148$]$.

I такий підхід видається до певної міри виправданим, оскільки представники філософської антропології зазначають, що людину слід вивчати такою, якою вона є в дійсності, в житті, тобто невигадану людину, не таку, якою їй слід бути згідно з ідеальними уявленнями. ... Адже її призначення, ії мета - жити вищими цінностями, множити їх, охороняти, насолоджуватись ними, передавати нащадкам. Тільки таке життя, як суто людське, цінність і сенс, тільки воно відповідає закладеним у людині духовним началам, що визначає те, що саме людина вибирає мету свого життя, сама визначає стратегію життєдіяльності $[25$, с. 59,60$]$.

У випадках втрати соціальної політики, яка б забезпечувала необхідний комплекс соціальних прав, уявляється рефлексія міграційних процесів. Чому так відбувається?

Очевидно, що насамперед йдеться про кризу. В американському суспільстві криза держави добробуту, пов'язана на думку Р. Інглхарта (який спираючись на розгалуженні соціальні дослідження) із тим, що еволюція американського суспільства відбувалась в контексті виходу на інший горизонт: «...від матеріалістичних цінностей (соціального добробуту, державної безпеки) до постматеріалістичних цінностей, які характеризуються індивідуальною якістю життя, відповідальністю аз навколишнє середовище, вільним вибором життєвого стилю та культурних пріоритетів...» [29, с. $34 ; 23$, с. 193]. Отже соціальні умови життя діставали пріоритет над суто структурними та системними безпековими державними сентенціями.

У такому ключі слід звернути увагу й на спостереження видатного психолога та мислителя К. Г. Юнга, який, аналізуючи проблемні питання свідомого та несвідомого, досить яскраво зазначає, що «крушение сознательной установки это всегда крушение мира в миниатюре...» [26].

За Юнгівською аналогією уявляється саме те, що причиною міграційного процесу є втрата людиною-громадянином потреби в державі, у іії здатності забезпечити реалізацію соціальних прав. По суті, втрачається мікросвіт та зв'язок людини і громадянина як найвищої соціальної цінності (ст.3 Конституції України) в державі із останньою.

Відповідно, реконструюючи ті чи інші підстави як причини прояву міграційного інтересу у засновках, виникає очевидним той факт, що 
вони перебувають у тісному взаємозв'язку із втратою людини-мігранта «віри в право» (за C.С. Алєксєєвим), у правопорядок та безпеку; відстежується зв'язок із втратою аксіологічного сенсу у послугах та діяльності держави, як гаранта дотримання та забезпечення основоположних прав та свобод людини і громадянина. У такому ключі людина (громадянин-мігрант) втрачає насамперед ментальний зв'язок із пропонуємою правдою та справедливістю. Людина (громадянин-мігрант) мігрує із своїм внутрішнім правовим світом, світом справедливості притаманний її внутрішній природі, правовою культурою до інших країн. Сама ж країна виступає як донор у постачанні соціального потенціалу для інших країн. Очевидним $€$ і те, що зазвичай мігрують люди/громадяни, які $€$ потенційно активними для реалізації низки соціальних та правових функцій держави (функцій в соціо-гуманітарної сфрери). По суті це втрата реальних соціальних активів та майбутнього держави із якої мігрують. Як наслідок, у такій державі залишаються люди, що не здатні до адаптування та нових швидких змін у житті із об'єктивних та суб'єктивних причин, а саме це: люди похилого віку, соціально незахищені особи, особи, які опинилися у скрутному соціальному становищі, діти, діти позбавленні батьківського піклування, інклюзивної освіти, діти із вадами здоров'я тощо. Усе це спричиняє утворенню соціального колапсу, соціального дисонансу із декларованим у Конституції України верховенства права, визначенням людини як найвищої соціальної цінності. Наслідки зріються і для бюджетного навантаження країни колосальний дисбаланс.

У філософсько-правовому сенсі тут слід якраз звернути на понятійний апарат саме постмодернізму права, який так чи інакше проявляється у правовій природі міграційних процесів, як соціальному феномені. Адже у юридичній енциклопедії зазначається, що якраз саме правовий постмодернізм пов'язують із тим станом, коли відбулася смерть людини як автора та суб'єкта історії чи то творця юридичних текстів. Постмодернізм наслідує обмеження свободи людини в умовах демократії. А його рефлексія - постмодернізму - сфокусована на позбавленні права об'єктивності, визначеності та стабільності; відсутності кореляції між верховенством права, правовими інститутами та свободою, рівністю та справедливістю. Водночас він здатний відобразити пористу легальність, або юридичну пористість, у ньому (постмодер- нізмі) відображаються численні сітки правопорядків, що змушують людей до переходу або ж певного втручання (стосовно до незаконного порушення прав). ... відстежується реконструкція. Деконтсрукція для постмодерністів - це насамперед дискурс справедливості, або голос справедливості як результат її реконструкції. До того ж засаду дискурсу справедливості становлять розрізнення права та справедливості, або закону і справедливості. Тут закон розуміється як легітимні, встановлені як юридичні системи, побудовані на основі досвіду. Саме через їх побудованість закони можуть бути «роз-будовані», тобто реконструйовані. Деконструкція закону покликана не руйнувати, а удосконалювати його, зробити гнучкішим та доступнішим для перегляду та покращення [3, с. 594, 595, 598]. Причому реконструкція відіграє переважно стверджувальну роль, оскільки здійснюється заради ствердження існування чогось недоконструйованого. Без цього у реконструкції не було б жодної мотивації. Зрештою, реконструкція дозволяє побачити в ній концепцію відповідальності перед іншим та за іншого [3, с. 599].

Тут можна бути певним у тому, що сентенція, що криється в дослідженні категорій «реконструкція» та «реконструкція», $€$ не чим іншим, як певними тими процесами, які спрямовані на зміну ціннісного буття людини, суспільства у соціальному сенсі.

Не було б зайвим звернути увагу на відображення схожих процесів, що спостерігаються у фрілософії права. До прикладу, адже як відмічає С.C. Сливка, саме «...процеси збереження порядку полягають у тому, що існуючі дрібні структури розмиваються, посилюються однорідністю, частини цілого зливаються у складну структуру, утворюється симетрична структура, сповільнюється динаміка і в людини виникає слабке відчуття різноманітних відхилень, що дає можливість отримати інформацію про подальшу поведінку...» [22, с. 155]. Це означає насамперед те, що прояв постмодернізму права дає підстави вести мову не стільки про деконструкцію соціального права, скільки його реконструкцію в силу міграційних процесів. Саме міграційні процеси виступають підставою для приведення нормативно-правового регулювання соціального права у відповідність.

До того ж, якщо правове суспільство у межах його формування в Україні уявляється через наявність двох особливих умов - «інституційної» (де такою інституційною умовою формування правового суспільства завжди висту- 
пають розвинуте громадянське суспільство і стала правова держава) та «не інституційної» (де така полягає у перевазі в суспільстві особистостей-громадян з розвиненою правосвідомістю, які $є$ реальними суб'єктами правовідносин даного суспільства і включені у морально-політико-правовий дискурс) [24, с. 198], то виникає питання, чи слід сформувати громадянське суспільство у міграційних процесах?, - відповідь тільки одна: очевидно що слід, адже забезпечення відтоку громадян-мігрантів через створення належних та повноцінних правових соціальних умов в Україні можливе саме через визначення та врахування антропологічних особливостей мігруючих.

Саме за таких обставин, деконструкція й стає рівноправним учасником та відповідною умовою динаміки законів, які $є$ одним із механізмів їх вдосконалення. До того ж слід мати на увазі те, що в галузі права деконструкції підлягають тільки ті частини тексту, які доступні інтерпретації та перетворення. Однак гранична засада закону, за визначенням, не $є$ обґрунтованою і тому реконструюванню не підлягає [3, с. 598]. Зрештою, важливим $є$ і те, що деконструкція не дає жодного горизонту передбаченості, на відмінну від платонівського ейдосу та кантівської регулятивної ідеї. Вона зіштовхує зі своїм краєм, межею, з тим, чого не має, з тим, що може настати, а може і не настати [3, с. 599].

По суті, за таких умов відстежується вияв до певної міри безсилля/недієвість прогностичної функції права у міграційних процесах, а також, появи феномену ризику, тобто, прояв безпекових тенденцій та сентенцій.

3 огляду на вищевикладене постає за очевидне, що з точки зору філософії права ідентифікація чинників міграційних процесів надає змогу пізнати спосіб буття людини в державі, власне - більш глибше визначити необхідні критерії для безпечного та належного існування людини, досягнення державою соціальних цілей та сенсу у своїй політиці, визначити соціальну функціональність правової системи, здатність забезпечити правопорядок, усунути вчасно соціальні ризики та конфлікти. Саме за таких умов і розкривається сама проблема впровадженої в державі належної соціальної політики як особливої функції держави, яку вона спроможна була б забезпечити для своїх громадян у правовий спосіб. 3 іншого боку, стає можливим розкрити питання гарантій наданих державою стосовно долання та впливу на процеси міграції, її здатності до позитивних трансформаційних соціальних процесів. I це все заради того, аби забезпечити стабільність кон'юнктури та рельєфу не тільки соціальної політики, скільки стану «безпекового соціального режиму». Як наслідок, правова доктрина соціальне право - як об'єктивне доктринальне міждисциплінарне правове явище - теж здатне змінюватися, фіксуючи правові результати для вироблення чинного безпекового соціального законодавства.

Висновки і пропозиції. Таким чином, у рамках проведеного дослідження важливо відмітити, що міграційні процеси змінюють соціальну кон'юнктуру права в державі. Соціальне право в такому разі вимагає вдосконалення у правовому регулюванні соцільно-правових та трудо-правових відносин у державі в незалежності від притоку чи відтоку мігрантів.

В антропологічному сенсі міграція як процес пояснюється зміною структури буття людини як суб'єкта права, громадянина в державі. Причому такі зміни можуть носити як характер вияву постмодерну права, так і характер суто антропологічний.

У першому випадку громадянин-мігрант постає у правовому бутті як особа, що втрачає суб'єктність в адаптаційний період міграційного процесу; до того ж відбуваються очевидні обмеження свободи людини навіть в умовах демократії (причини можуть бути викликані режимом обмежень в наслідок пандемій); самі соціальні права людини-мігранта втрачають визначеність та стабільність, втрачається сенс прав через неспроможність держави контролювати прос міграції, впливати на забезпечення соціальних прав мігрантів. Мова права для громадян-мігрантів подається в мікронаративі: вона пов'язана із так званою угодою до меншин права та суб'єктивним його тлумаченням громадянином-мігрантом.

У період COVID-19 спостерігається прояв постмодерну в аспекті відмови держави враховувати ряд соціальних прав людини і громадянина, як і навпаки - людини до держави.

За таких обставин розгортається саме антропологічне осмислення буття соціального права в міграційних процесах. Адже громадянин-мігрант відшуковує сенси між щастям та свободою, конфліктом чи кооперацією. Зрештою, міграційна «програма» громадянина-мігранта пояснюється зміною сенсу способу буття людини як суб'єкта права в державі.

Держава, як суб'єкт права, теж проходить етапи міграції, що пояснюються постмодерними 
та антропологічними особливостями. Причина у цьому є глобалізаційні процеси квазісуб'єктів.

Процеси, зумовлені трудовою міграцією і міграцією, спричиненою COVID-19, вказують на зміну насамперед соціальних цінностей права на роботу, права на безпеку, право на безпечне середовище, як і права на життя. Адже людина (мігрант) воліє обирати скоріш вже спосіб не стільки соціального добробуту через гідну працю та гідні умови життя, скільки збереження життя, попри повернення на батьківщину; держава та органи державної влади навіть припускають вибір того, кому слід зберегти життя, a хто є приреченим, без надання належної медичної, соціальної допомоги. У різних версіях повернення на батьківщину чи то неповернення, причина міграції маркується у філософсько-правовому ключі із втратою сенсів добробуту та правопорядку в тій чи іншій країні.

Слід констатувати, що використання в дослідженні антропологічного методу/підходу дозволяє з'ясувати основні вікові, професійно-трудові, освітні та інші соціальні особливості громадян, яких слід відносити до мігрантів чи то таких, які перебувають у стані міграційних процесів; визначити пріоритетні напрямки ключових інтересів громадян-мігрантів, які не можуть бути чи то не могли бути реалізовані у країні, з якої відбулась/триває міграція. Такі особливості $€$ не чим іншим, як реальними маркерами запиту на зміни в державі, реальними показчиками виявлення соціального ризику при забезпеченні соціальної безпеки.

Соціальне право в міграційних процесах характеризує себе аморфно, адже тісно пов'язане із соціальною природою людини. Остання ж є продуктом природного права, відповідно до концепції якого людина-мігрант, насамперед, керується найважливішими цивілістичними цінностями такими як життя, здоров'я, свобода, бажання бути у безпеці. Така властивість соціального права досить різко дисонує із позитивним правом, системою державного апарату, системою правопорядку. Як наслідок, міграційні процеси здатні змінювати рельєф країни, із якої мігрують, залишаючи її в безпорадному стані в силу втрати людського потенціалу як стратегічної цінності будь якої держави; з іншого боку, міграційні процеси й можуть не найкращим чином позначатись на соціально-правовій сфері країн, до яких мігрують, утворюючи позитивні та негативні елементи у її бутті.

Зрештою, прояв антропогенезу міграційних процесів під призмою постмодерну соціального права $€$ багатогранним, міждисциплінарним соціально-правовим феноменом, що вказує на перманентність цих проблем у праві, в державі. Це означає, що соціальна та правова держава повинна мати ефективно діючий інструмент для забезпечення соціальної стабільності та соціальної безпеки на тлі міграційних процесів, а власне відповідну стратегію визнану та прийняту на державному рівні.

\section{Список використаної літератури:}

1. Амо́рфные вещества́ (тела́) - ... значення слова. Вікіпедія. URL : https://ru.wikipedia.org/ wiki/\%D0\%90\%D0\%BC\%D0\%BE\%D1\%80\%D1 $\% 84 \% D 0 \% B D \% D 1 \% 8 B \% D 0 \% B 5$ \%D1\%82\%D 0\%B5\%D0\%BB\%D0\%B0.

2. Бандура О.О. Філософрія права доби постмодерну: людина та її права. Проблеми фрілософії права. 2005. Том III. № 1-2. С. 250-255.

3. Велика українська юридична енциклопедія: у 20 т. Харків : Право, 2016. Т. 2 Філософія права/ редкол.: С.І. Максимов (голова) та ін. ; Нац. акад.прав.наук України ; Ін-т держави і права імені В.М. Корецького НАН України ; Нац. юрид. ун-т імені Ярослава Мудрого. 2017. 1128 с.

4. Глобалізація і трудова міграція в Європі : монографрія/Б. М. Юськів. Рівне : видавець О.М. Зень, 2009. 479 c.

5. За прогнозом НАНУ, в Україні коронавірусом може заразитися 22 млн людей - КМДА. Українська правда. Субота, 21 березня 2020, 20:24. URL : https://www.pravda.com.ua/ news/2020/03/21/7244577/.

6. Интеллектуальные хроники пандемии : сборник статей / под ред. А.В. Тимофеев. Днипро, 2020. 115 c.

7. Коваленко P.І. Правове регулювання соціальної безпеки а збереження трудового потенціалу. Розвиток трудового потенціалу як складова соціальної безпеки України : монографія / С.В. Вишновецька, М.І. Іншин, В.Л. Костюк, I.C. Сахарук та ін. / за ред. М.І. Іншина, І.C. Сахарук. Київ : ФОП Маслаков, 2018. С. 129-144.

8. Кривицька О. Міграційні процеси в Україні: конфллікт ідентифрікацій та ризики «відторгнення». Політичний менеджмент. № 1-2, 2013. С. 79-88.

9. Малиновська О. Мігранти, міграція та українська держава: аналіз управління зовнішніми міграціями. Київ : Вид. НАДУ, 2004. 236 с.

10.Малиновська О. Трудова міграція: соціальні наслідки та шляхи реагування. Київ : НІСД, 2011. $40 \mathrm{c}$.

11. Малиновська O.A. Вплив пандемії COVID-19 на трудову міграцію громадян України та можливі напрями державного реагування. Національний інститут стратегічних досліджень: Соціальна політика / Аналітична записка від 20.05.2020 р. 
URL : https://niss.gov.ua/doslidzhennya/socialnapolitika/vpliv-pandemii-sovid-19-na-trudovumigraciyu-gromadyan-ukraini-ta.

12.Малиновская Н.В. Постмодерн и его влияние на понимание права. Вестник ВГУ. Серия: Право. № 2. 2009. С. 78-90.

13.Махонюк О.В. Формування та розвиток ринку міграційних послуг в Україні : дис. на здобут. канд. екон. наук : 08.00.07 - демографрія, економіка праці, соціальна економіка і політика. Інститут регіональних досліджень імені М.І. Долішнього НАН України. Вінниця. 253 с.

14.Міграція в Україні: фракти і цифрри. Представництво Міжнародної організації з міграції в Україні. Друге видання, 2013. 16 с.

15.Міграція 3 України зростає і наближається до критичної. НВ/події/ 7 квітня 2018, 16:04. URL : https://nv.ua/ukr/ukraine/events/ mihratsija-z-ukrajini-zrostaje-i-nablizhajetsja-dokritichnoji-2462687.html.

16.Мелкевік Б. Постмодернізм, право та «прощання з розумом». Критика постмодерної правової Концепції. Філософрія права $і$ загальна теорія права. № 2/2013. С. 215-228.

17.16-а. Антропологія міграційних процесів у постмодерні як ре(де)конструкція соціального права. Державна політика у сфері трудової міграції: правові, економічні, демографрічні, освітні аспекти: матеріали міждисциплінарного круглого столу з нагоди Міжнародного дня мігранта (м. Київ, 18 грудня 2019 р.) / за ред. І.С. Сахарук, А.М. Магомедової. Київ : ФОП Маслаков, 2020. С. 89-97.

18.Пандемія і Міграція. Як пандемія COVID-19 впливає на трудових мігранток? ГО «Платформа прав людини» / Новини / 9 червня 2020 року. Публікація проекту з партнерських організацій Institute for Analysis and Policy Dialogue IfAP (Берлін), RUSMPI - Institute on Migration Policy (Берлін), GenderMediaCaucausus Journalists' Association (Грузія) за фрінансової підтримки Міністерства закордонних справ Німеччини. URL : https://www.ppl.org.ua/ pandemiya-i-migraciya-yak-pandemiya-covid-19vplivaye-na-trudovix-migrantok.html.

19.Ружицький О., Майструк А. ЄСПЛ на охороні прав мігрантів. Юридична форма «EVERLEGAL». Публікації / 17.09.2019. URL : https://everlegal.ua/ espl-na-okhoroni-prav-migrantiv.
20.Сайтарли І.А., Іщенко О.М., Приятельчук А.О. Нариси з сучасної фрілософії: Навчальний посібник для магістрів та здобувачів ступеня доктора філософії/ І.А. Сайтарли, О.М. Іщенко, А.О. Приятельчук (за ред.. академіка НАН України Л.В. Губерського). Київ : «ВАДЕКС», 2016. $370 \mathrm{c}$.

21.Сахараук I.C. Сутність та основні напрями розвитку трудового потенціалу України. Розвиток трудового потенціалу як складова соціальної безпеки України : монографія / С.В. Вишновецька, М.І. Іншин, В.Л. Костюк, І.С. Сахарук та ін. / за ред. М.І. Іншина, І.С. Сахарук. Київ : ФОП Маслаков, 2018. С. 57-110.

22. Сіньова Л.М. Юридичні гарантії реалізації трудових прав вимушених переселенців. Розвиток трудового потенціалу як складова соціальної безпеки України : монографрія / за ред. М.І. Іншина, І.С. Сахарук. Київ : ФОП Маслаков, 2018. C. 494-519.

23.Сливка С.С. Філософрія права : навч. посіб. Київ : Атіка, 2012. 256 с.

24.Пасько Я.І. Соціальна держава і громадянське суспільство: співпраця versus протистояння : монографія. Київ : ПАРПАН, 2008. 272 с.

25. Філософрія права : підруч. для студ. юрид. вищ. навч. закл. / за ред. О.Г. Данильяна. Харків : Право, 2017. 208 с.

26. Філософрія права : навчальний посібник. / О.О. Бандура, С.А. Бублик, М.Л. Заінчковський та ін. ; за заг.ред. М.В. Костицького, Б.Ф. Чміля. Київ : Юрінком Інтер., 2000. 336 с.

27. Юнг Карл Густав. Сознание и бессознательное. Пб.: Университетская книга, 1997. 544 с. URL : https://www.twirpx.com/file/1352723/.

28.Ярмиш О.Н. Міграційні процеси як державоі правоутворюючий чинник. Міграційні процеси в Україні і світі: історико-юридичні аспекти. Матеріали XIV Міжнародної історико-правової конфреренції 4-7 вересня 2005 р., м. Балаклава / Ред. колегія: О.В. Тимощук (голова), Д.В. Велігодський (відп. секр.), О.Н. Ярмиш, І.Б. Усенко, Л.О. Зайцев, О.М. Редькіна. Сімферополь : ДіАйПі, 2005. С. 3-9.

29.Bruce M. The Coming of the Welfare State. New York., 1975. 207p.

30.Savicka A. Postmaterialism and Globalization: Roland Inglehart. Vilnus. Researsh Institute of Culture, Philosophy and Arts, 2004.133 p.

\section{Melnyk Ya. Ya. Anthropogenesis of migration processes in the prism of postmodern social law}

The article considers the anthropogenesis of migration processes under the prism of postmodern social law. Emphasis is placed on the fact that migration processes are not only multifaceted, interdisciplinary in nature as a phenomenon, but also closely and, in some cases, directly related to the state of social security in the state, in fact, with the legal model of the state and its ability to ensure the proper level of social rights in the country. Analyzing numerous statistical data, case law and scientific achievements in the field of philosophy of law and social law, the author sees 
a strong connection of migration processes with the mental loss of human justice in the social regime and law and order, which leads to disappearance / non-recognition as a full participant. in the state. As a result, socio-legal fluctuations, fluctuations in the instability of legal certainty, ensuring the rule of law, instability and the manifestation of crises, social risks, do not allow to plan the future as a citizen, to be worthy and worthy in light of declared principles of law. In such circumstances, the migrant citizen loses nothing but the legal meaning of realizing his life in this country. In turn, this has a negative effect on state social policy, on the state's ability to perform its social functions, and is followed by a loss of human potential. This has a negative effect on the financial and social spheres, the labor market and so on. Also, due to the intensification of migration processes, the relief and conjuncture of social law is changing, because on the one hand, as a result of its reconstruction, the legal structure and meaning of social rights in the state are being restructured. Thus, the author proves that migration processes are a permanent element of the anthropogenesis of social law.

The author concludes that the social and legal state must have an effective tool to ensure social stability and social security in the context of migration processes, and in fact the relevant strategy is recognized and adopted at the state level.

Key words: migration, social security, social rights, anthropology of law, postmodernism of law, philosophy of social law, COVID-19. 